José Carlos de Carvalho Baboin

\title{
O TRATAMENTO JURISPRUDENCIAL DA GREVE POLÍTICA NO BRASIL
}

\author{
DiSSERTAÇÃO DE MESTRADO
}

Orientador Professor Associado Jorge Luiz Souto Maior

FaCUldade de Direito da UniVERSidAde de SÃo PAUlo

SÃo PAUlo - SP

2013 
José Carlos de Carvalho Baboin

\section{O TRATAMENTO JURISPRUDENCIAL DA GREVE}

POLÍTICA NO BRASIL

Dissertação de Mestrado apresentada à Banca Examinadora da Faculdade de Direito da Universidade de São Paulo como requisito parcial à obtenção do título de Mestre.

Orientador: Professor Associado Jorge Luiz Souto Maior

Faculdade de Direito da Universidade de São Paulo

SÃo PAUlo - SP

2013 
José Carlos de Carvalho Baboin

\section{O TRATAMENTO JURISPRUDENCIAL DA GREVE POLÍTICA NO BRASIL}

Dissertação de Mestrado apresentada à Banca Examinadora da Faculdade de Direito da Universidade de São Paulo como requisito parcial à obtenção do título de Mestre.

Data da banca:

Nome:

Título:

Instituição

Nome:

Título:

Instituição

Nome:

Título:

Instituição 
Dedico este trabalho aos meus avós maternos Tereza e Anésio e aos meus avós paternos Waldermar (in memoriam) e Ignês (in memoriam). 


\section{Agradecimentos}

Ao meu orientador Prof. Jorge Luiz Souto Maior, pelos ensinamentos e pela compreensão

Aos membros da banca de qualificação Prof. Marcus Orione Gonçalves Correia e Prof. Paulo Eduardo Vieria de Oliveira, pelo grande auxílio e pelos conselhos valiosos

Aos meus pais Rozângela e José Carlos, e aos meus irmãos Marco e Silvia, por serem meus exemplos e minha força

À Natalia, minha companheira, por todo o amor

Aos amigos de Caieiras, da Federal e da Sanfran, pela felicidade de compartilharmos nossas vidas

In memoriam de meus amigos Rafael Azevedo Fortes Alves, Bruno Tuon Perim e Denise Pimentel Spera, por serem parte de mim 
Melitón diz:

- Esta é a terra que nos deram.

Faustino diz:

- O quê?

Eu não digo nada. Eu penso: "Méliton não está com a cabeça no lugar. Há de ser o calor que faz com que fale assim. O calor atravessou o seu chapéu e esquentou a sua cabeça. Senão, por que diz o que diz? Que terra nos deram Melitón? Aqui não tem nem aquele tantinho de terra que o vento ia precisar para fazer um redemoinho."

Juan Rulfo. E nos deram a terra. 


\section{RESUMO}

O presente estudo tem por objetivo questionar o tratamento dado às greves com finalidade política pela jurisprudência brasileira. Tomando como base a metodologia principiológica dos direitos sociais, contestamos as restrições impostas aos trabalhadores em relação à finalidade política da greve e apontamos as contradições existentes entre o comando legal e a aplicação da lei. Buscamos demonstrar que o conceito atual de greve política utilizado por nossos juristas é insuficiente e não corresponde à amplitude assegurada por nossa Carta Magna.

Palavras chave: greves, greve política, greves atípicas, jurisprudência, Direito Social 


\section{RÉSUMÉ}

La présente étude vise à remettre en question le traitement des grèves avec des finalités politiques par la jurisprudence brésilienne. Basé sur la méthodologie spécifique des droits sociaux, nous avons analysé les restrictions imposées aux travailleurs par rapport à l'objectif politique de la grève et nous avons également souligné les contradictions entre la lettre de la loi et son application. Nous cherchons à montrer que le concept actuel de grève politique utilisé par les juristes est insuffisant et ne correspond pas à l'ampleur garantie par notre Constitution.

Mots-clés: grève, grèves politiques, grèves atypiques, jurisprudence, droit social 


\section{SUMARIO}

1 - INTRODUÇÃO .10

1.1 - Um estudo jurisprudencial sobre a greve política …………................................................................... 10

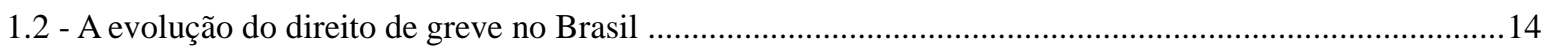

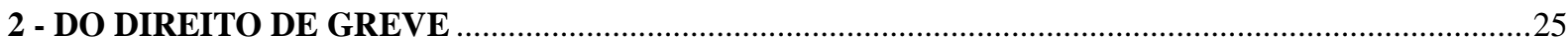

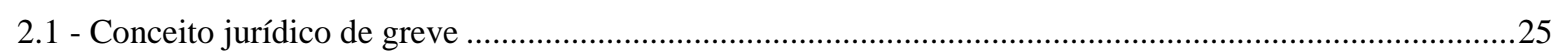

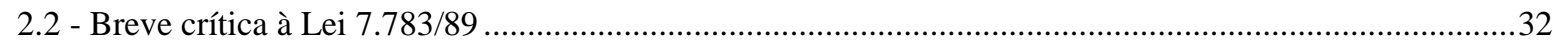

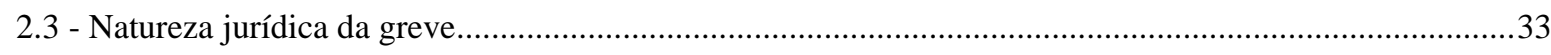

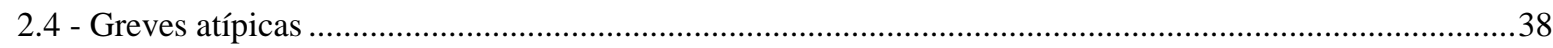

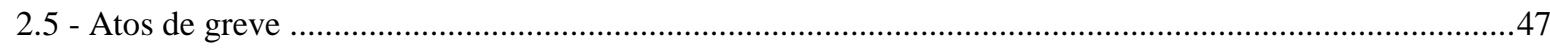

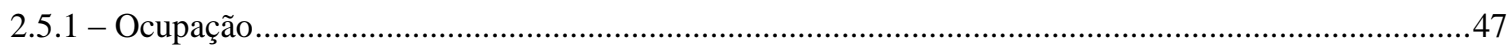

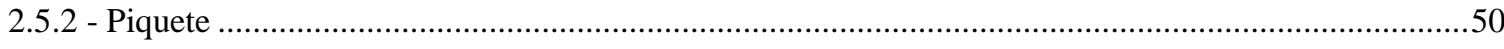

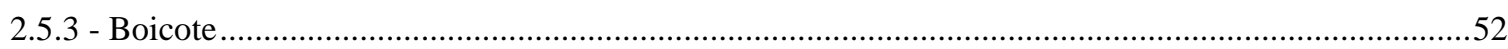

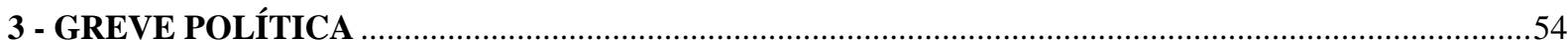

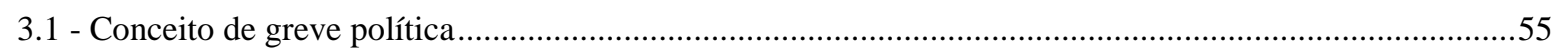

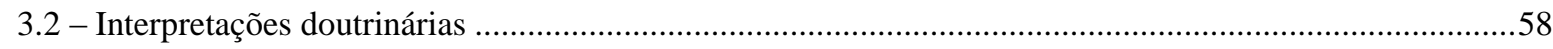

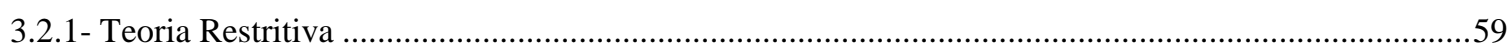

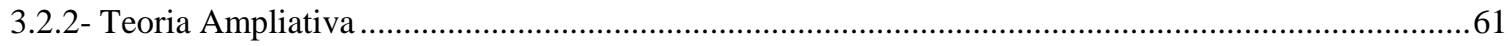

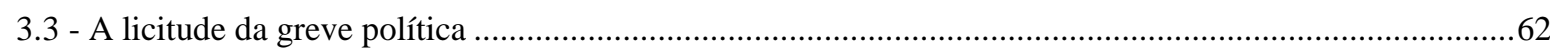

4 - O PODER JUDICIÁRIO BRASILEIRO E A GREVE POLÍTICA ………………………………........76

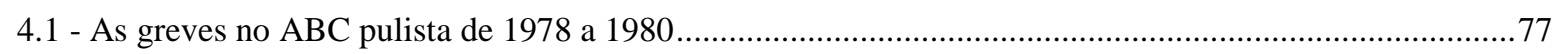

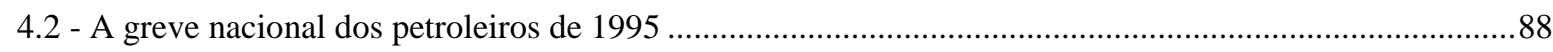

4.3 - A greve dos trabalhadores em transporte de Campinas em 1998 …………………..............................99

4.4 - A greve dos trabalhadores nas indústrias urbanas do Rio de Janeiro em 1998 .......................................103

4.5 - As greves dos metroviários de São Paulo em 2006 ..........................................................................107

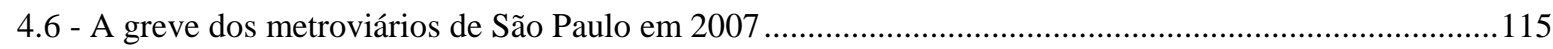

4.7 - A greve dos trabalhadores e estudantes da Pontifícia Universidade Católica de São Paulo em 2012 .....122

CONCLUSÃO

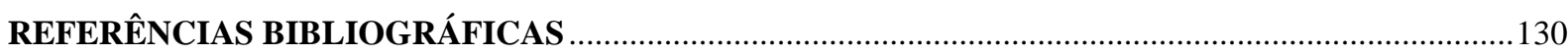

ANEXOS 


\title{
1 - INTRODUÇÃ̃o
}

\author{
"Nesses dias ninguém pode aferrenhar-se naquilo que "é capaz". Na \\ improvisação está a força. Todos os golpes decisivos são desferidos com a mão \\ esquerda". \\ Benjamin, Walter. Rua de mão única
}

\section{1 - Um estudo jurisprudencial sobre a greve política}

Há uma notável negligência por parte de nossos acadêmicos em relação ao estudo da jurisprudencia. Se o estudo de movimentos grevistas é recorrente entre sociólogos e historiadores, entre os juristas a questão coletiva é geralmente apreciada apenas em seu aspecto teórico. Entretanto, a crítica da aplicação destas teorias em decisões judiciais é fundamental para sairmos de nossa torre de marfim. A transposição da teoria jurídica para a realidade ocorre através das decisões judiciais, resultado de um trabalho confluente de juízes, advogados, procuradores e teóricos do Direito. Estas decisões tem reflexos diretos na vida dos trabalhadores e em sua busca por melhores condições sociais.

Estamos cientes de nossas limitações, tanto as impostas pela própria ciência do Direito como as decorrentes da distância entre a academia e a sociedade - sobretudo em uma sociedade tão injusta e desigual quanto a brasileira. Isto não impede, contudo, a realização de um estudo que possa contribuir para uma reflexão crítica sobre as decisões proferidas por nossos tribunais sobre as greves políticas. A reflexão de Pachukanis foi também nossa reflexão quando da produção desta obra:

\footnotetext{
"Minha tarefa não era a de resolver em definitivo todos os problemas da teoria do direito ou mesmo alguns. Meu desejo era mostrar unicamente sob que ângulo é possível abordá-los e como se devem equacionar os problemas."1
}

Buscamos com este trabalho estudar as restrições impostas aos trabalhadores em relação à finalidade política da greve através do estudo de decisões judiciais e apontar a contradição existente entre o comando legal e a aplicação da lei. Nosso objetivo é justamente demonstrar que o conceito atual de greve política utilizado por nossos juristas é

${ }^{1}$ PACHUKANIS, E.B. Teoria Geral do Direito e Marxismo. São Paulo: Acadêmica, 1988, p.14. 
insuficiente e não corresponde à amplitude assegurada por nossa Carta Magna. Assim como Edelman, "esta elucidação nós não a quisemos abstracta, mas concreta, no sentido de que analisaremos as 'incarnações sucessivas' de uma 'questão de direito' com que nossos tribunais estão actualmente ocupados"2. Desta maneira, pretendemos auxiliar na construção de um Direito que seja útil ao destino dos homens.

Este é um trabalho que se desenvolve sob a ótica jurídica trabalhista. O Direito do Trabalho se apresenta como um ramo autônomo da ciência do direito, uma vez que possui uma lógica interpretativa própria e seus princípios são distintos das outras áreas jurídicas.

Pode-se perceber a singularidade do Direito do Trabalho em relação aos outros setores do ordenamento jurídico em todas as facetas da experiência jurídica: no conteúdo de suas regras substantivas, nos sujeitos que as estabelecem, nos instrumentos de sua elaboração e nos procedimentos para colocá-las em prática ou torná-las efetivas ${ }^{3}$.

Tal distinção deve ser bem frisada pois, apesar de ser clara e constantemente reiterada, grande parte dos teóricos indevidamente utilizam lógicas e princípios de outros ramos do direito ou mesmo de outras ciências para a interpretação de normas e fatos relativos ao Direito do Trabalho. Não é raro verificarmos, por exemplo, a aplicação da lógica contratualista do direito civil como solução milagrosa para resolução dos conflitos trabalhistas, ou a aplicação de conceitos economicistas para negar aplicabilidade a normas jurídicas. Estas lógicas devem ser afastadas do campo do Direito Social eis que, como defende Jean Emmanuel Ray, a "análise puramente econômica do direito é totalmente condenável no plano principiológico, pois ela permitiria ao empregador comprar indiretamente o exercício de um direito constitucional"4.

Esta aplicação de lógicas estranhas ao Direito do Trabalho é perpetuada em todos os meandros do Direito do Trabalho, mas parece adquirir maior força quando se trata do direito de greve, em especial quando se trata de greves que defendam algo além do "estrito contrato de trabalho". Isto porque "quando vislumbrado à luz de outras áreas do

\footnotetext{
${ }^{2}$ EDELMAN, Bernard. O direito captado pela fotografia. Centelha: Coimbra, 1976, p.160.

3 VAlVErde, Antonio M., Gutiérrez, Fermín R.S., Murcia, Joaquín G. Derecho Del Trabajo. $5^{\text {a }}$ Ed. Madrid: Tecnos, 1996. P. 46.

${ }^{4}$ RAY, J-E. Droit du travail Droit vivant. $19^{\circ}$ edition, Paris, Liaisons, 2010, p.688.
} 
conhecimento, é no Direito Coletivo que o Direito Laboral se revela com as suas mais importantes particularidades" ${ }^{5}$.

Concordando com as bases metodológicas propostas por Souto Maior, verificase o conceito de Direito do Trabalho como:

(...) o ramo do Direito (social) composto de normas dinâmicas, extraídas de regras e princípios historicamente instituídos, que, integrado ao patrimônio jurídico da classe trabalhadora e direcionado pelo Estado (Social), organiza o modelo de produção capitalista, regulando as relações de emprego, consideradas pelo aspecto da exploração do capital sobre o trabalho, numa perspectiva nacional e internacional, com vistas a limitar os interesses estritamente econômicos para preservar a paz mundial e construir a justiça social por meio da instrumentalização da melhoria progressiva das condições de trabalho e de vida dos trabalhadores, legitimando a atuação política destes, promovendo a solidariedade, impulsionando a democracia e proporcionando a distribuição da riqueza produzida, além de favorecer o exercício da ética e o desenvolvimento da racionalidade necessária para a preservação e a elevação da condição humana (dignidade humana) ${ }^{6}$.

Desta maneira, o Direito do Trabalho deve ser entendido como "instrumento decisivo para a formação e a defesa da justiça social, ainda que, concretamente, em um primeiro momento, só consiga minimizar as injustiças"7.

Os valores fundamentais do Direito do Trabalho que norteiam (ou deveriam nortear) tanto sua criação legislativa quanto sua aplicação judicial são os de que o trabalho humano não é mercadoria de comércio e de que a aplicação das normas trabalhistas serve à melhoria progressiva e constante das condições sociais e econômicas (de vida e de trabalho) do trabalhador ${ }^{8}$. Estes princípios possuem a função extremamente importante de servir como ponto de partida para a crítica da própria realidade. Estes valores servem de

\footnotetext{
${ }^{5}$ CORREIA, Marcus O.G. Direito Constitucional do Trabalho - Relações coletivas, in Correia, Marcus O.G.(org), Curso de Direito do Trabalho. São Paulo: LTr, 2007, vol. I, p. 25.

${ }^{6}$ MAIOR, Jorge Luiz Souto. Curso de Direito do Trabalho - Teoria Geral Do Direito do Trabalho. Volume I, Parte I. São Paulo: LTR, 2011, p.620-621.

${ }^{7}$ Idem. O Direito do Trabalho como instrumento de justiça social. São Paulo: LTR, 2000, p.259.

${ }^{8}$ MAIOR, Jorge L.S. e CORREIA, Marcus O.G., O que é Direito Social, in Correia, Marcus O.G.(org), Curso de Direito do Trabalho. São Paulo: LTr, 2007, vol. I, p. 27-28.
} 
parâmetro para a configuração da legalidade ${ }^{9}$ dentro da lógica sistêmica do Direito do Trabalho.

Necessário ressaltar também o caráter conferido ao Direito de Greve como um direito fundamental. A greve é um Direito Social constitucionalmente garantido. Sua fundamentalidade decorre do reconhecimento da necessidade de concretização dos direitos sociais para assegurar a proteção do ser humano contra a arbitrariedade dos poderes políticos e econômicos. Como aponta Bonavides:

\begin{abstract}
A observância, a prática e a defesa dos direitos sociais, a sua inviolável contextura formal, premissa indeclinável de uma construção material sólida desses direitos, formam hoje o pressuposto mais importante com que fazer eficaz a dignidade da pessoa humana nos quadros de uma organização democrática da Sociedade e do Poder. (...) Sem a concretização dos direitos sociais não se poderá alcançar jamais a 'sociedade livre, justa e solidária', contemplada constitucionalmente como um dos objetivos fundamentais da República Federativa do Brasil. ${ }^{10}$
\end{abstract}

Por ser um direito fundamental, a greve se reveste de proteção especial perante eventuais limitações, sejam elas impostas por leis ordinárias ou por interpretações jurisprudenciais que imponham limites que impeçam seu efetivo exercício. A greve, tal como garantida na Constituição, possuiu sentido amplo e sob esta ótica deve ser aplicado. No entendimento de José Afonso da Silva:

\begin{abstract}
Vê-se, pois, que ela (a greve) não é um simples direito fundamental dos trabalhadores, mas um direito fundamental de natureza instrumental e desse modo se insere no conceito de garantia constitucional, porque funciona como meio posto pela Constituição à disposição do trabalhadores (...) para a concretização de seus direitos e interesses. ${ }^{11}$
\end{abstract}

\footnotetext{
${ }^{9}$ MAIOR, Jorge Luiz Souto. Curso de Direito do Trabalho: Teoria Geral do Direito do Trabalho, Vol I, Parte I, São Paulo: LTR, 2011, p.551-572.

${ }^{10}$ BONAVIDES, Paulo. Curso de Direito Constitucional. 26a Ed. São Paulo: Malheiros, 2011, p.657.

${ }^{11}$ DA SILVA, José Afonso. Curso de Direito Constitucional Positivo. 30ªed. São Paulo: Malheiros, 2008, p.305.
} 
Sob esta ótica desenvolveremos este trabalho, objetivando uma análise crítica de nossa jurisprudência e apontando as insuficiências conceituais dadas por nossos magistrados a respeito da greve política. Buscamos assim, através da crítica, a desconstrução dos conceitos jurisprudenciais restritivos existentes, bem como sua superação através de interpretações que respeitem a importância e amplitude conferidas ao direito de greve pela Constituição.

O presente estudo está metodologicamente dividido em quatro partes. Após esta introdução que apontou o tema a ser abordado e definiu os limites e objetivos do presente estudo, apresentaremos uma curta análise da evolução histórica do direito de greve. A segunda parte se apresenta como um estudo do instituto jurídico da greve, na qual será tratado seu conceito e delimitação, seu tratamento jurídico e as principais controvérsias envolvendo a questão paredista.

Esta apresentação conceitual da greve servirá de base para adentrarmos na terceira parte do estudo, onde serão aprofundadas as particularidades relativas à greve política. Além de seu conceito, serão apresentadas as divergências teóricas sobre a possibilidade ou não do exercício legal de uma greve política no Brasil. Somente após este suporte teórico será desenvolvida a questão da licitude das greves políticas.

Por fim, a quarta parte será dedicada à análise de jurisprudência. Utilizando o suporte teórico dos capítulos anteriores, focaremos em um estudo crítico dos julgados que abordam a greve política, demonstrando sua [in]adequação com as normas e princípios afetos à matéria.

\section{2 - A evolução do direito de greve no Brasil}

Para melhor compreender este importante instituto do Direito Social, faz-se necessária uma breve análise de sua evolução normativa no Brasil. Através da demonstração da historicidade do direito de greve é possível compreender melhor sua evolução como instrumento para o desenvolvimento de melhores condições econômicas e sociais aos trabalhadores. O estudo histórico possibilita também a percepção crítica do direito de greve na atualidade, uma vez que se verifica uma construção prática e teórica em busca de seu amplo exercício. 
Pode-se dizer que o marco inicial, não apenas para o surgimento do direito de greve no Brasil, mas sim para o verdadeiro desenvolvimento do direito trabalhista nacional, foi a Lei n³.353 de 13-05-1888, a chamada Lei Áurea, que aboliu o modelo escravagista. Com a extinção desse modelo de organização, a relação empregatícia se tornou o principal instrumento de conexão do trabalhador livre ao sistema produtivo, de vinculação do trabalho ao sistema socioeconômico.

Justamente por este motivo, o sistema jurídico nacional era silente quanto à greve em seu ordenamento anterior a 1890. Constitucionalmente, esta ausência legislativa ocorreu tanto na Carta do Império de 1824 quanto na primeira republicana, de 1891.

Somente após a proclamação da República, com a entrada em vigor do Código Penal em outubro de 1890, houve a primeira menção à greve, que era considerada ilícito criminal $^{12}$. Contudo, devido principalmente ao esforço e à pressão das campanhas realizadas pelo recém-criado Partido Operário, após dois meses esta conduta deixou de ser criminalizada, através do Decreto $\mathrm{n}^{\circ} 1.162$ de 12-12-1890, assinado pelo Marechal Deodoro $^{13}$, que modificou o disposto no Código Penal. Este Decreto estabelecia que seriam puníveis então apenas os movimentos grevistas que se dessem por meio de atos de ameaça, constrangimento ou violência.

Com isto o instituto da greve deixa de ser tratado como delito. Mas esta mudança ocorreu apenas no campo teórico, pois como aponta Evaristo de Moraes Filho, apesar do novo tratamento dado à greve pelo legislador, a prática dos aplicadores e interpretes da lei não foi alterada.

(...) as autoridades policiais, administrativas e também as judiciárias continuaram a negar esse direito, como se nenhuma modificação tivesse havido no Código recém-promulgado. Qualquer espécie de greve, por mais pacifica e ordeira que

\footnotetext{
${ }^{12}$ Código penal de 1890. Capítulo VI: Dos crimes contra a liberdade do trabalho. Art. 206 - Causar ou provocar cessação ou suspensão de trabalho, para impor aos operários ou patrões augmento ou diminuição de serviço ou salário:

Pena e de prisão cellular por um a três meses.

$\S 1^{\circ}$ - Se para esse fim se colligarem os interessados:

Pena - aos chefes ou cabeças da colligação, de prisão cellular por dois a seis meses.

$\$ 2^{\circ}$ - Se usarem de violência:

Pena - de prisão cellular por seis meses a um anno, além das mais em que incorrerem pela violência.

${ }^{13}$ MorAES, Evaristo de. Apontamentos de direito operário. Rio de Janeiro: Imprensa Nacional, 1905. Pp.59 e 63.
} 
fosse, era proibida e violentamente reprimida, presos os grevistas, dispensados dos seus empregos e alguns estrangeiros expulsos do país. ${ }^{14}$

Com a crise da política do café com leite e a consequente eclosão da Revolução de 1930, ascende Getúlio Vargas ao poder, implantando o Governo Provisório, em outubro do mesmo ano. Apesar deste período se caracterizar pela intensa centralização política, em um primeiro momento não houve alteração jurídica para a criminalização de movimentos paredistas. Pode-se aludir a tanto o fato da Carta Constitucional de 1934 não fazer menção ao instituto da greve.

O enraizamento do entendimento expresso no Decreto $\mathrm{n}^{\circ} 1.162 / 1890$ pode ser percebido na Consolidação das Leis Penais de 1932, em seu art. 204, que criminaliza não a cessação ou suspensão de trabalho em si, mas sim o uso de ameaças ou violências para realizar o movimento grevista ${ }^{15}$. Contudo, apesar da descriminalização, ainda não se pode falar de greve como direito, uma vez que tal instituto ainda não encontra proteção em nenhum preceito legislativo.

Com o início do Estado Novo em 1937, pode-se perceber uma grande influência da teoria corporativista na política nacional. Tal é perceptível no último parágrafo do artigo 139 da Constituição de 1937, que enuncia que "a greve e o lock-out são declarados recursos anti-sociais nocivos ao trabalho e ao capital e incompatíveis com os superiores interesses da produção nacional. O Código Penal de 1940, em seu artigo 201, criminalizava a participação em greves em serviços de interesse coletivo ou que interrompessem obras públicas ${ }^{16}$. Para completar o processo de repressão ao movimento grevista, em 1943 houve a promulgação da Consolidação das Leis do Trabalho que em seus artigos 722/725, expressamente proibiram a greve e o lock-out.

\footnotetext{
${ }^{14}$ MoRAES FILHO, Evaristo de. Direito de Greve. In Revista LTr Julho/86. São Paulo: LTr, 1986. p. 776.

${ }^{15}$ Consolidação das Leis Penais (Decreto n ${ }^{\circ} 22.213$ de 14-12-1932). Capítulo VI: Dos crimes contra a liberdade do trabalho. Art. 204 - Constranger, ou impedir alguém de exercer a sua industria, commercio ou officio; de abrir ou fechar os seus estabelecimentos e officinas de trabalho ou negocio; de trabalhar ou deixar de trabalhar em certos e determinados dias:

Pena - de prisão cellular por três meses a um anno

$\S 2^{\circ}$ - Causar ou provocar cessação ou suspensão de trabalho por meio de ameaças ou violências para impôr aos operários ou patrões augmento ou diminuição de serviço ou salário:

Pena - de prisão cellular por um a dois annos.

${ }^{16}$ Código Penal de 1940. Art. 201 (Paralisação de trabalho de interesse coletivo) - Participar de suspensão ou abandono coletivo de trabalho, provocando a interrupção de obra pública ou serviço de interesse coletivo:

Pena - detenção, de seis meses a dois anos, e multa.
} 
Este entendimento legal acerca da greve teve reflexos inclusive na ordem internacional, uma vez que obrigou os representantes brasileiros Conferência de Chapultepec, realizada no México em 1945, a subscreverem com restrições a Ata no que dizia respeito ao reconhecimento do direito de greve. Pode-se perceber tal ponto em um texto emitido pelo Serviço de Informação Legislativa da época:

\footnotetext{
"Ainda agora, na Conferência de Chapultepec, os delegados de nosso País ficaram isolados, durante a discussão do item $10^{\circ}$ da Carta Econômica das Américas, que recomenda a aceitação, por todas as Repúblicas americanas, do direito de greve a ser assegurado aos trabalhadores. Segundo os despachos ontem vindos da capital mexicana, todos os delegados que participaram dos trabalhos desta importante conferencia pan-americana votaram de acordo com a proposta norte-americana, favorável ao direito de greve, excetuados os representantes do Brasil. O Sr. João Carlos Vital chegou a declarar que a proposta estava em antagonismo com a Carta de 10 de novembro. Depois, houve uma reunião privada dos representantes brasileiros, da qual resultou o seguinte: a delegação de nosso país aceitaria a proposta, com a ressalva de não se aplicar a mesma aos países cujas Constituições proíbam as greves, o que constitui um disparate" ${ }^{17}$.
}

No mesmo sentido, apoiando a posição tomada, pode-se apresentar uma nota circular da Federação das Indústrias do Estado de São Paulo (FIESP):

\begin{abstract}
“A Conferência de Chapultepec e o Direito de Greve - A seguir, foi longamente discutida pela Casa a posição da indústria em face dos movimentos grevistas que se vêm registrando no País, tendo falado diversos diretores, apreciando o assunto sob todos os seus aspectos. Achando-se presente o Dr. Armando de Arruda Pereira, que integrou a delegação que representou o Brasil na conferência do México, foi o mesmo convidado pelo Sr. Presidente a expor qual o ponto de vista adotado pelo nosso País em Chapultepec, com relação ao direito de greve. Esclareceu o Dr. Armando de Arruda Pereira que o nosso delegado manifestouse contrário ao direito de greve, por estar em desacordo com as disposições da Constituição vigente no País, tendo o Brasil aceito o projeto com a ressalva de que esse direito não seria reconhecido nos países em que a Magna Carta proíbe a
\end{abstract}

\footnotetext{
${ }^{17}$ Martins, Norma Izabel Ribeiro. Direito de Greve. Brasília: Serviço de Informação Legislativa, 1964. pp.19-20
} 
greve. A greve, por consequência, é um recurso ilegal: os que a ela recorrem estão contra a lei"18.

Contudo, apesar da restrição inicial, é inegável a influência exercida por esta Carta internacional nos trabalhos constituintes de 1946. Em março, devido à pressão de diversos grupos políticos e sociais, foi o Presidente da República, o General Eurico Gaspar

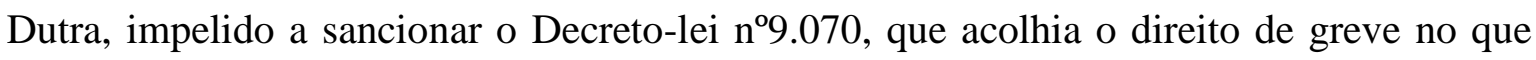
dizia respeito a atividades acessórias, sem, entretanto, reconhecê-lo nas chamadas “atividades essenciais". Contudo, embora assegurasse o exercício do direito de greve, este Decreto-Lei impunha inúmeras restrições e condicionantes ao seu exercício, o que na prática acabava impossibilitando a paralização legal de trabalhadores.

Com a Constituição Federal de 18 de setembro de 1946, o direito de greve foi finalmente admitido no ordenamento nacional como um direito dos trabalhadores, estabelecido no artigo 158, que possuía a seguinte redação: “'É reconhecido o direito de greve, cujo exercício a lei regulará”. Novamente Evaristo de Moraes Filho nos lembra que, apesar de a nova Constituição reconhecer a grave como direito, "continuaram as autoridades administrativas e judiciárias a aplicar o Decreto-Lei $\mathrm{n}^{\circ} 9.070$, restritivo da sua

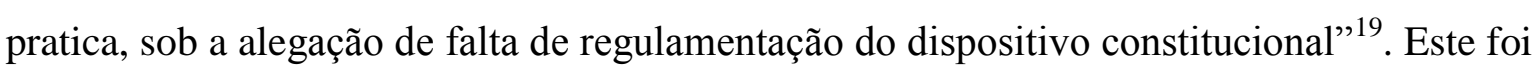
inclusive o entendimento do STF, que reconheceu a vigência do antigo Decreto-Lei ${ }^{20}$.

Temístocles Brandão Cavalcanti se manifestou contrário a este posicionamento das autoridades administrativas e judiciárias, explicitando que "as medidas que contornem as dificuldades decorrentes da greve competem ao poder público, mas isto não importa em levar ao extremo de negar-se o próprio direito, por meio de discriminações sem amparo nos textos constitucionais (...) qualquer interpretação deve, portanto, orientar-se no sentido de assegurar esse direito, aplicando-se restritivamente qualquer limitação"21.

Neste ponto, é fundamental perceber a importância desta análise histórica. A profunda diferença entre texto constitucional e aplicação da norma, neste exemplo tão explícita e que nos parece tão óbvia, ainda hoje persiste, tópico este que será tratado em

\footnotetext{
${ }^{18}$ Ibidem, p.20.

${ }^{19}$ MORAes Filho, Evaristo de. Op. Cit. p. 776.

${ }^{20}$ ver Recurso extraordinário n48.207(SP) Relator Ministro Luiz Gallotti, DJ de 17.10.63, p.1018, in MARTINS, Norma Izabel Ribeiro; Op. Cit., pp.19-20, p.271 usque 278.

${ }^{21}$ Cavalcanti, Temístocles Brandão. A Constituição Federal Comentada. Rio de Janeiro: José Konfino, 1949, Vol. IV. p.43.
} 
momento oportuno, pois é objeto de análise desta dissertação as diferenças existentes entre o texto legal vigente acerca do direito de greve e as aplicações, geralmente opostas, destes textos na realidade fática.

Neste período, apesar da restrição imposta pelas autoridades competentes, os movimentos grevistas no Brasil se desenvolveram e ampliaram, motivados principalmente pelas dificuldades econômicas que a política social vigente acarretava para os trabalhadores.

Como demonstra um acórdão da época, proferido no processo TRT/RJ $141 / 1949^{22}$, "constitui falta grave - mal grado o direito de greve que lhes é assegurado pela Constituição Federal em seu artigo 158 - é a cessassão coletiva do trabalho em desatenção no que estabelece preliminarmente o Decreto-Lei no 9070 de 15 de março de 1946". O tratamento repressivo direcionado aos trabalhadores também é relatado neste acórdão: "é evidente que os operários que se encontravam na residência de um seu camarada, na ocasião em que foram surpreendidos, presos e maltratados pela polícia, se achavam no uso de outro direito - o de reunião".

O artigo 158 da Constituição de 1946, que levou ao reconhecimento do direito de greve como um direito de todos os trabalhadores, só foi efetivamente regulamentado por norma específica em junho de 1964, através da Lei nº4.330, editada pouquíssimo tempo após o golpe de estado que levou os militares ao poder no Brasil. Embora menos restritiva que o Decreto-Lei $\mathrm{n}^{\circ} 9.070$, a Lei $\mathrm{n}^{\circ} 4.330$ ainda apresentava grandes entraves e limitações ao exercício da greve.

É interessante constatar este fato uma vez que hoje, com o distanciamento histórico, nos é permitido analisar melhor a real intenção desta lei. É patente o antagonismo que esta regulamentação apresenta com o pensamento do regime militar; contudo, cabe lembrar que se tratava de um momento de instabilidade do novo poder, e esta concessão objetivava acalmar justamente aqueles mais receosos com o golpe: os trabalhadores. A brevidade desta lei tende ainda mais a comprovar tal fato: logo que se consolidou o poder dos militares, promulgou-se a nova Constituição Federal, em janeiro de 1967, que em seu artigo 157, $\S 7^{\circ}$, estabeleceu: "Não será permitida a greve nos serviços públicos e atividades essenciais, definidas em lei”. O que se deu, em suma, foi o retorno à lógica do Decreto-Lei $\mathrm{n}^{\circ 9.070 .}$

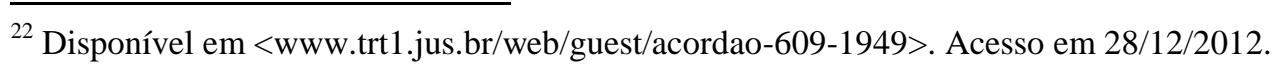


Em 29 de setembro de 1969, foi editado o Decreto-Lei no898, que estabelecia penalidades para as greves que descumprissem o artigo 157 da Constituição, além daquelas que tivessem uma finalidade política, que fizessem "propaganda subversiva" ou que demonstrassem solidariedade com alguma das causas acima.

Após dez anos de opressão pela ditadura militar, com a promessa de uma abertura "lenta, segura e gradual" por parte do general Ernesto Geisel em 1974, o movimento dos trabalhadores finalmente vislumbra a possibilidade de uma maior liberdade para o exercício da greve.

\begin{abstract}
"(...) eu me encorajo, sem mais rodeios a dizer ao senhor presidente, que nós precisamos urgentemente, de readquirir a liberdade de fazer greve, suprimida há mais de dez anos. O senhor presidente há de me contestar, afirmando que existe a Lei de Greve de 1964, que se encontra em pleno vigor. Ocorre, senhor presidente, que essa lei impede que o recurso da greve seja usado em toda sua plenitude, na defesa dos nossos legítimos interesses. Tanto isso é verdade, que a nossa e outras entidades de trabalhadores vêm reclamando contra ela há mais de dez anos. (...) Sem o direito de greve, a principal arma de todos os trabalhadores, jamais conseguiremos firmar uma convenção coletiva de trabalho com os patrões. Eles tão somente se recusam a participar das negociações. Ademais, o direito de greve é universal, e o Brasil talvez seja um dos poucos países onde esse direito não possa ser usado com toda a liberdade." ${ }^{23}$
\end{abstract}

Segundo o depoimento deste metalúrgico de São Bernardo em 1975, podemos perceber que a greve, embora teoricamente positivada como um direito, era na prática tratada como ilícito através da limitação decorrente de inúmeros requisitos e burocracias fixados em lei para seu exercício.

Mesmo todo este aparato repressivo não foi suficiente para impedir a eclosão de movimentos grevistas. Após um longo período sem movimentos paredistas de grande expressividade, em maio de 1978 os trabalhadores da empresa Scania em São Bernardo do Campo deflagaram uma greve que marcou o início do período de grandes greves no ABC paulista.

Em seguida, trabalhadores de diversas outras fábricas também realizaram movimentos paredistas, como os da Ford, Chrysler, Mercedes, Volks e Brastemp, todos

${ }^{23}$ Jornal Tribuna Metalúrgica, n²8, 1975, p.3. 
com saldo claramente positivo aos obreiros. No final de 1978, foram realizadas 118 greves em todo o território nacional.

Esta inquietação dos trabalhadores não passou despercebida pelo governo. Em 17 de dezembro de 1978 foi editada a Lei $n^{\circ} 6.620$, que tinha como objetivo definir os crimes contra a segurança nacional e estabelecer as respectivas punições. Em seu artigo 27, caracterizava como crime "impedir ou dificultar o funcionamento de serviços essenciais, administrados pelo Estado ou executados mediante concessão, autorização ou permissão”.

O ápice desta limitação ao movimento paredista se deu em agosto de 1978, quando entrou em vigência o Decreto-Lei $n^{\circ} 1.632$. Este Decreto-Lei foi ainda mais restritivo, proibindo a greve nos serviços públicos e nas atividades essenciais "de interesse da segurança nacional", que, na prática, poderia impossibilitar o próprio direito de greve, uma vez que a relação destas atividades poderia ser ampliada por mero decreto do Presidente da República.

Uma observação importante que se depreende da leitura deste Decreto-Lei e da comparação de seu texto com o de outras leis é que quando se tratava de legalizar o exercício do direito de greve, a conceituação de greve sempre ocorria de forma extremamente restritiva. A Lei $\mathrm{n}^{\circ} 4.330$ de 1964, que reconheceu a greve como direito, em seu artigo segundo, considerava greve: "a suspensão coletiva e temporária da prestação de serviços a empregador, por deliberação da assembleia geral de entidade sindical representativa da categoria profissional interessada na melhoria ou manutenção das condições de trabalho vigentes na emprêsa ou emprêsas correspondentes à categoria, total ou parcialmente, com a indicação prévia e por escrito das reivindicações formuladas pelos empregados, na forma e de acôrdo com as disposições previstas nesta lei".

Já quando se tratava de estabelecer punições aos grevistas, a interpretação de greve ocorria de forma extremamente ampliativa. No Decreto-Lei nº1.632 de 1978, que tinha como único objetivo fixar sanções aos trabalhadores que participavam de greves, conceituava em seu artigo segundo que "para os efeitos deste Decreto-Lei, constitui greve a atitude da totalidade ou de parte dos empregados que acarrete a cessação da atividade ou diminuição de seu ritmo normal". A greve era tratada sempre de forma a dificultar seu exercício. Trata-se de uma restrição que pode soar absurda para a maioria dos juristas hodiernos; entretanto, tais restrições eram plenamente admitidas pela doutrina da época assim como as restrições atualmente existentes com relação à greve são acolhidas sem maiores críticas. 
Com o processo de redemocratização política no Brasil, fez-se necessário uma reforma na legislação trabalhista vigente. Com tal objetivo, em 22 de maio de 1985, o Ministério do Trabalho apresentou ao então Presidente da República José Sarney, um anteprojeto de lei que tratava especificamente do direito de greve e negociação coletiva, visando unificar a legislação e revogar os artigos 611 a 625 da CLT, a Lei nº4.330/64 e o Decreto-Lei $\mathrm{n}^{\circ} 1.632 / 78$. Contudo, este anteprojeto foi duramente criticado; poder-se-ia dizer que "na realidade o anteprojeto da 'Nova República', em muito pouco ou quase nada, avançou no sentido de se garantir o pleno exercício do direito constitucional de greve. Toda a legislação, elaborada para regulamentar o direito de greve, tem sido no sentido de coibir, dificultar e praticamente impedir o exercício desse direito" ${ }^{24}$.

Em 1988 entrou em vigor a nova Constituição Federal, a chamada “Constituição Cidadã”, que dispunha em seu artigo 9": "É assegurado o direito de greve, competindo aos trabalhadores decidir sobre a oportunidade de exercê-lo e sobre os interesses que devam por meio dele defender". Ao não proibir nenhum tipo de greve e nem limitar os grupos que dela podem fazer uso (com exceção feita aos militares, de acordo com o artigo 142, $\left.\S 3^{\circ}, \mathrm{IV}\right)$, a nova Constituição alterou o parâmetro para determinação da legalidade de uma greve, consagrando o princípio da responsabilidade, na medida em que sujeita os responsáveis por abusos às penas da lei.

A Lei n7.783/89, denominada "Lei da greve", tratava do exercício deste direito, regulando os parâmetros que a Constituição estabeleceu como competência de legislação infraconstitucional. Entre outros pontos, define as atividades essenciais e regula o atendimento das necessidades inadiáveis da comunidade, de acordo com o $\S 1^{\circ}$ do artigo $9^{\circ}$ da Constituição. Em seu artigo $18^{\circ}$, finalmente se dá a revogação expressa da Lei $\mathrm{n}^{\circ} 4.330 / 64$ e do decreto-Lei $\mathrm{n}^{\circ} 1.632 / 78$.

Esta evolução histórica é fundamental para compreendermos o significado e a extensão atual do direito de greve. No decorrer deste estudo, iremos nos deparar com inúmeras visões restritivas do direito de greve. Verificar o texto positivado e o momento histórico tanto de sua criação quanto de sua aplicação auxilia a refutação de diversos argumentos.

Finalizamos apresentando a tabela abaixo, que apresenta a evolução do tratamento jurídico da greve. A importância desta comparação reside na comprovação da

${ }^{24}$ Meneguelli, Jair Antônio. Direito do Trabalhador. In Folha de S.Paulo, 15.06.85, p.03 
amplitude das normas vigentes a respeito do direito de greve. Quando as legislações buscaram restringir este direito, o faziam de forma expressa, como podemos observar no texto do Decreto-Lei 9.070/46 e da Lei 4.330/64. A ausência de limitações conferida aos trabalhadores para decidir sobre os interesses a defender através da greve, como consta Constituição de 1988, só pode ser interpretada como ampla liberdade. A rica reflexão promovida através desta comparação será importante no estudo da possibilidade de exercício da greve com finalidade política. 


\begin{tabular}{|c|c|}
\hline Legislação & Texto legal \\
\hline Constituição Federal de 1946 & $\begin{array}{l}\text { Art } 158 \text { - É reconhecido o direito de greve, cujo } \\
\text { exercício a lei regulará. }\end{array}$ \\
\hline Decreto-lei 9070/46 & $\begin{array}{l}\text { Art. } 2^{\circ} \text { - A cessação coletiva do trabalho por parte } \\
\text { de empregados sòmente será permitida, observadas } \\
\text { as normas prescritas nesta lei. } \\
\S 1^{\circ} \text { Cessação coletiva do trabalho é a deliberada } \\
\text { pela totalidade ou pela maioria dos trabalhadores } \\
\text { de uma ou de várias empresas, acarretando a } \\
\text { paralisação de tôdas ou de algumas das respectivas } \\
\text { atividades. } \\
\S 2^{\circ} \text { As manifestações ou atos de solidariedade ou } \\
\text { protesto, que importem em cessação coletiva do } \\
\text { trabalho ou diminuição sensível e injustificada de } \\
\text { seu ritmo, ficam sujeitos ao disposto nesta lei. }\end{array}$ \\
\hline Constituição de 1967 & $\begin{array}{l}\text { Art 158- A Constituição assegura aos } \\
\text { trabalhadores os seguintes direitos, além de outros } \\
\text { que, nos termos da lei, visem à melhoria, de sua } \\
\text { condição social: } \\
\text { XXI - greve, salvo o disposto no art. } 157, \S 7^{\circ} \text {. }\end{array}$ \\
\hline Lei $4.330 / 64$ & $\begin{array}{l}\text { Art } 2^{\circ} \text { Considerar-se-á exercício legislativo da } \\
\text { greve a suspensão coletiva e temporária da } \\
\text { prestação de serviços a empregador, por } \\
\text { deliberação da assembléia geral de entidade } \\
\text { sindical representativa da categoria profissional } \\
\text { interessada na melhoria ou manutenção das } \\
\text { condições de trabalho vigentes na emprêsa ou } \\
\text { emprêsas correspondentes à categoria, total ou } \\
\text { parcialmente, com a indicação prévia e por escrito } \\
\text { das reivindicações formuladas pelos empregados, } \\
\text { na forma e de acôrdo com as disposições previstas } \\
\text { nesta lei. }\end{array}$ \\
\hline Constituição de 1988 & $\begin{array}{l}\text { Art. } 9^{\circ} \text { É assegurado o direito de greve, } \\
\text { competindo aos trabalhadores decidir sobre a } \\
\text { oportunidade de exercê-lo e sobre os interesses que } \\
\text { devam por meio dele defender. } \\
\S 1^{\circ}-\text { A lei definirá os serviços ou atividades } \\
\text { essenciais e disporá sobre o atendimento das } \\
\text { necessidades inadiáveis da comunidade. } \\
\S 2^{\circ}-\text { Os abusos cometidos sujeitam os } \\
\text { responsáveis às penas da lei. }\end{array}$ \\
\hline Lei 7.783/89 & $\begin{array}{l}\text { Art. } 2^{\circ} \text { Para os fins desta Lei, considera-se legítimo } \\
\text { exercício do direito de greve a suspensão coletiva, } \\
\text { temporária e pacífica, total ou parcial, de prestação } \\
\text { pessoal de serviços a empregador. }\end{array}$ \\
\hline
\end{tabular}




\section{2 - DO DIREITO DE GREVE}

\section{1 - Conceito jurídico de greve}

Inicialmente, para que melhor se possa apreender o objeto do estudo, faz-se necessária sua delimitação metodológica. Historicamente, o uso da palavra greve "acabou por exprimir as formas de descontentamento e de protesto dos trabalhadores, as suas práticas de luta. O conceito foi sendo modelado por essas formas e por essas práticas, embora para tal modelação tivessem contribuído também a repressão policial e judiciária" 25 .

Pode-se considerar a greve, antes de qualquer coisa, um fato social, e seu estudo é objeto dos mais diversos ramos das ciências humanas, tais como a história, a sociologia e o direito. Além disso, trata-se de um fato social desvinculado da regulamentação jurídica, uma vez que existe e atua independentemente da sua prescrição normativa. O advento da positivação da greve é posterior à greve como fato social.

Há divergências entre os juristas a respeito da relação ente greve como fato social e greve como fato jurídico. Parte da doutrina entende a greve como fato social, não vislumbrando nela uma verdadeira relevância na ordem jurídica, considerando-a apenas um acontecimento no mundo concreto das relações de trabalho. Nesta linha de raciocínio, defendem que por ser um um simples fato social a greve não poderia ser objeto de direito, pois seria a negação de uma situação jurídica oriunda do contrato de trabalho, que obriga o empregado a fornecer uma prestação laboral. Concluem que a efetividade da greve, portanto, se dá apenas nas esferas históricas e culturais, não podendo se enquadrar no direito por ser algo cuja realidade é anterior ou exterior ao direito ${ }^{26}$.

Há também aqueles que consideram a greve apenas como um fato social por considerá-la antijurídica: por ser um meio de coação direta, que substitui o direito como forma de solução de conflitos, a greve representa a própria negação do direito e a falência do Estado. Tese defendida por juristas com forte inclinação patronal, nesta linha enquadrase o pensamento de Mozart Victor Russomano, que a define como mero fato social,

\footnotetext{
${ }^{25}$ LEAL, Antonio da Silva. O conceito de greve e o problema das fontes terminológicas e conceituais do Direito do Trabalho, in Temas de Direito do Trabalho - Direito do Trabalho na Crise. Poder empresarial. Greves Atípicas, IV Jornadas Luso-hispano-brasileiras de Direito do Trabalho. Coimbra: Coimbra, 1990. Pag.565

${ }^{26}$ Gomes, Orlando e GotTsChalk, Elson. Curso de Direito do Trabalho. $12^{\mathrm{a}}$ Ed. Rio de Janeiro: Forense, 1991. P.626.
} 
afirmando haver uma violência inerente a todas as greves e que é incompatível com a solução pacífica dos conflitos, fundamento que considera básico para o Direito. Além disto, afirma que a deflagração de uma greve ocorre quando da impossibilidade do Estado de oferecer meios jurídicos eficazes para solucionar os conflitos que geraram a paralisação $^{27}$.

Por fim, há dentre a doutrina que considera a greve um fato social aqueles pensadores que não a veem como antijurídica, mas sim ajurídica, por não poder ser objeto de direito por sua própria natureza, existindo apenas fora do direito e não contra o direito. Consideram-na um fenômeno social que ocorre espontaneamente dentro do meio social, tornando infrutífera qualquer tentativa de regulamentação.

Apesar da grande discussão da greve como direito e como fato social, é de se considerar inicialmente que a importância real da greve encontra-se na sua essência como fato social, como meio real e espontâneo de manifestação e reivindicação dos trabalhadores por melhores condições de vida e trabalho, na reafirmação de que trabalho não é mercadoria de comércio.

A greve é um movimento que independe, em sua origem, de qualquer regulamentação legal, pois uma vez que os trabalhadores se encontrem em um momento histórico no qual vislumbrem a necessidade de realizar uma determinada greve, certamente não será uma norma que deterá os impulsos reivindicatórios desta massa de obreiros. Como aponta Orione, "a tentativa de limitar-se juridicamente este fato, maior do que o direito, é uma das buscas mais constantes dos ordenamentos jurídicos diversos. O fato, no entanto, continua, neste ponto, sendo maior e mais forte do que as forças do próprio direito" ${ }^{28}$.

Ao contrário da maioria dos direitos trabalhistas, que obtiveram sua existência social construída através da normatividade jurídica, como férias e horas extras, a positivação da greve surgiu como resposta a este exercício de expressão social dos trabalhadores por ser um fato social juridicamente relevante.

Os efeitos produzidos pela greve invariavelmente reverberam nas relações jurídicas, o que a transforma em importante ponto de discussão para o direito. É de se

\footnotetext{
${ }^{27}$ Russomano, Mozart Victor. Princípios Gerais de Direito Sindical. Rio de Janeiro: Forense, 1995. P.249250 .

${ }^{28}$ CORREIA, Marcus O.G. Direito Constitucional do Trabalho - Relações coletivas, in Correia, Marcus O.G.(org), Curso de Direito do Trabalho. São Paulo: LTr, 2007, vol. I, p. 25.
} 
concluir, portanto, que para nós, estudiosos e operadores do Direito, a greve possui grande importância também como fato social que se desdobra em fato jurídico.

No nosso ordenamento jurídico, o direito de greve é tratado como instituto do Direito do Trabalho. Mas é importante ressaltar que a palavra "greve" possui uso que se estende a distintos âmbitos sociais, não apenas ao Direito do Trabalho. A greve se relaciona com o Direito do Trabalho, mas a ele não se limita.

O conceito jurídico de greve é objeto de grande controvérsia entre a doutrina, justamente por que as limitações de sua atuação estão atreladas ao que cada jurista entende por greve.

Para Ildélio Martins, “enquanto fato social, a greve será simplesmente a paralisação concertada do trabalho, por todos ou pela maioria dos empregados visando a certas reivindicações - para o Direito, como ato jurídico, terá ela sempre uma forma prescrita em lei e deverá sempre atender a fins especificados na lei consequente"29.

Na visão de Amauri Mascaro Nascimento, “o conceito jurídico de greve não oferece dificuldade, uma vez que é incontroverso que se configura como tal a paralisação combinada do trabalho para o fim de postular uma pretensão perante o empregador"30.

Já para Mauricio Godinho Delgado, a greve também pode ser conceituada como um meio de autotutela dos trabalhadores, um "instrumento direto de pressão coletiva, aproximando-se do exercício direto das próprias razões efetivado por um grupo social ${ }^{31 \text { ". }}$

Para Alfredo Montoya Melgar, a greve é em sua raiz um feito puramente "natural", baseado na reação instintiva do homem frente a determinados comportamentos que reputa injustos ou adversos ${ }^{32}$.

Paul Durand afirma que "a qualificação de greve deve ser dada a toda interrupção, de caráter temporário, motivada por reivindicações suscetíveis de beneficiar o

\footnotetext{
${ }^{29}$ MARTINS, Ildélio. Greves Atípicas: Identificação, caracteres e efeitos jurídicos, in Temas de Direito do Trabalho - Direito do Trabalho na Crise. Poder empresarial. Greves Atípicas, IV Jornadas Luso-hispanobrasileiras de Direito do Trabalho. Coimbra: Coimbra, 1990. Pag.488

${ }^{30}$ NAScimento, Amauri Mascaro. Compêndio de Direito Sindical. 4ªEd. São Paulo: LTr, 2006. P.433.

${ }^{31}$ Delgado, Mauricio Godinho. Curso de Direito do Trabalho. $4^{\text {a }}$ Ed. São Paulo: LTr, 2005. P.1.414.

${ }^{32}$ Melgar, Alfredo Montoya. Derecho del Trabajo. 19a ed. Madrid: Tecnos, 1998. P.715
} 
conjunto ou uma parte do pessoal e que encontram apoio num grupo suficientemente representativo da opinião operária"33.

Gérard Lyon-Caen escreve que a greve consiste na cessação coletiva e acordada do trabalho, a fim de exercer uma pressão sobre o chefe da empresa ou sobre o poder público para sustentar reivindicações. Assim caracterizada, ela (a greve) é um instrumento de luta essencial para os trabalhadores ${ }^{34}$.

Todas estas conceituações doutrinárias demonstram a ampla gama de interpretação sobre o conceito jurídico de greve. Em decorrência desta pluralidade de visões, faz-se necessário apresentar ao leitor a interpretação com a qual nos filiamos. Trata-se de matéria delicada, pois como aponta Krotoschin "quanto mais concretamente se define a greve, maiores restrições geralmente envolvem a definição" ${ }^{35}$.

No Brasil, o artigo $9^{\circ}$ da Constituição Federal, que trata especificamente do instituto da greve, possui a seguinte redação:

Art. $9^{\circ}$ - É assegurado o direito de greve, competindo aos trabalhadores decidir sobre a oportunidade de exercê-lo e sobre os interesses que devam por meio dele defender.

$\S 1^{\circ}$ A lei definirá os serviços ou atividades essenciais e disporá sobre o atendimento das necessidades inadiáveis da comunidade.

$\S 2^{\circ}$ Os abusos cometidos sujeitam os responsáveis às penas da lei.

Como se pode perceber, a constituição de 1988 não possui em seu texto um conceito restritivo de greve; ao contrário, o seu texto assegura um amplo exercício deste direito pelos trabalhadores.

Concomitantemente, deve-se analisar a Lei $\mathrm{n}^{\circ} 7.783 / 89$, a chamada "Lei da greve", mais especificamente dos seguintes artigos:

\footnotetext{
${ }^{33}$ Apud SÜSSEKIND, Arnaldo; MARANHÃo, Délio; VIANNA, Segadas. Instituições de Direito do Trabalho. 13a Edição. São Paulo: LTr, 1993. P.1082.

${ }^{34}$ LyON-CAEN, Gérard; PELISSIER, Jean; SuPIOT, Alain. Droit du Travail. $17^{\circ}$ Ed. Paris: Dalloz, 1994. P.828

${ }^{35}$ KROTOSCHIN, Ernesto. Tratado práctico de derecho del trabajo. Volumen II, 4a Ed. Buenos Aires:

Depalma, 1981, p.202.
} 
Art. $1^{\circ}$ - É assegurado o direito de greve, competindo aos trabalhadores decidir sobre a oportunidade de exercê-lo e sobre os interesses que devam por meio dele defender.

Art. $2^{\circ}$ - Para os fins desta Lei, considera-se legítimo exercício do direito de greve a suspensão coletiva, temporária e pacífica, total ou parcial, de prestação pessoal de serviços a empregador.

Percebe-se que esta lei, mesmo restringindo a dimensão de greve dada pela Constituição, ainda assim assegura um conceito amplo do que é, juridicamente, greve. É importante salientar que, em momento algum, o direito de greve foi limitado quanto aos seus interesses reivindicatórios; pelo contrário, consta na Constituição e é reiterado na Lei 7.783/89 que compete aos trabalhadores decidirem "sobre os interesses que devam por meio dele defender". Este ponto, denominado causa final da greve, é o motivo central da discussão doutrinária no que concerne à legitimidade da greve política, dividindo a doutrina entre as teorias ampliativa e restritiva, que serão oportunamente desenvolvidas.

Com base no artigo $2^{\circ}$ da Lei $n^{\circ} 7.783 / 89$, pode-se analisar o conceito de greve para o ordenamento jurídico brasileiro. Inicialmente, a greve caracteriza-se como suspensão de prestação de serviços a empregador.

Esta suspensão do trabalho deve ser coletiva, o que significa que a greve deve ser um ato gerado por um grupo, jamais podendo representar um ato individual. Não é possível, portanto, a greve de apenas um trabalhador. Entretanto a lei não define número mínimo de participantes, abordando este aspecto apenas no plural, de forma indeterminada, o que possibilitaria uma greve de, por exemplo, dois trabalhadores.

Além destes pontos, deve-se atentar para o caráter temporário da greve. Isto significa que a greve não representa uma paralisação definitiva, mas sim provisória do trabalho, ou seja, o trabalhador para de trabalhar com o intuito de retornar ao labor assim que atendida sua reivindicação. A maioria das greves se desenvolve como uma paralisação provisória por tempo indeterminado; isto não impede, contudo, que um movimento paredista tenha data de término pré-estabelecida. A paralisação definitiva no trabalho representa o abandono do emprego, que se dá pelo rompimento intencional do contrato de trabalho por parte do empregado, o que não ocorre com a greve. 
Outra característica apontada pela lei é que o desenvolvimento da greve deve ocorrer de maneira pacífica. Isto porque a proteção a ela oferecida não inibe seus agentes de sanções de responsabilidade civil ou penal, caso esta se desenvolva com violência ou cause danos, por exemplo. Entretanto, devemos lembrar que o conceito de "exercício pacífico" do direito de greve é um dado impossível de ser analisado in abstrato, como se a ideia de paz fosse matematicamente mensurável. Não há uma definição do que é o exercício "pacífico" da paralisação. O exercício do direito de greve deve ser analisado com base na conjuntura que o originou. Se analisarmos os casos de greves tidas como "violentas", certamente será possível concluir que grande parte foi originada como resposta a uma atitude violenta por parte do empregador ou do governo. Os salários aviltantes, a jornada de trabalho extenuante, as pressões produtivas e metas impossíveis, a terceirização de funcionários são exemplos de violência por parte da empresa. O conflito entre as classes sociais é um conflito violento, mas que oprime apenas o trabalhador. Em se tratando de um conflito entre partes desiguais, muitas vezes a exigência de "exercício pacífico" descontextualizado acaba sendo apenas um meio de repressão do movimento grevista, o que não se pode admitir ${ }^{36}$.

Finalmente, como última característica da greve expressa no artigo $2^{\circ}$ da Lei $n^{\circ} 7.783 / 89$, a greve pode ser uma paralisação tanto parcial quanto total de prestação pessoal de serviços a empregador. Esta paralisação pode se dar tanto sob o prisma do volume de obreiros que cruzam seus braços quanto do volume de trabalho realizado.

Quanto à quantidade de trabalhadores envolvidos, a greve pode ocorrer tanto por unanimidade, onde todos os trabalhadores de uma determinada empresa ou de um determinado sindicato aderem à greve, bem como pode se dar de maneira parcial, onde apenas alguns trabalhadores, ou um determinado setor, ou mesmo um tipo especifico de funcionários realizam o movimento paredista.

Já se tratando do volume de trabalho realizado, a paralisação pode ser total, quando os grevistas cruzam os braços e nada produzem, se abstendo de todas as suas tarefas laborais, ou pode ser parcial, quando os trabalhadores realizam modificações na prestação de serviços, como é o caso da greve de zelo, da chamada “operação-padrão", da greve de rendimento, entre outras. Esta posição que adotamos, entretanto, não é consenso

\footnotetext{
${ }^{36}$ Como expressa Brecht em seu famoso poema: A corrente impetuosa é chamada de violenta / Mas o leito do rio que a contem / Ninguém chama de violento. / A tempestade que faz dobrar as bétulas/ É tida como violenta / E a tempestade que faz dobrar / Os dorsos dos operários na rua?
} 
na doutrina e jurisprudência. Um exemplo de posição divergente é a decisão do STJ no caso da greve dos servidores da Polícia Federal e da Polícia Rodoviária Federal em 2012, que proibiu a realização de operação-padrão por ser esta "uma tática que provoca inegáveis perturbações no desempenho de quaisquer atividades administrativas" ${ }^{37} 38$.

Por ser caracterizada como "suspensão de prestação de serviços a empregador", a doutrina majoritária exclui da conceituação de greve outros fenômenos coletivos de protesto, como as greves de estudantes, de consumidores e as greves de fome. Para os defensores deste posicionamento "as afinidades sociológicas que estes fenômenos têm com a greve - com ela comungam a essência coletiva, o elemento de concertação e o intuito de pressão sobre outra entidade para obter um determinado objetivo do grupo - não iludem a sua profunda dissemelhança jurídica"39.

Contudo, não comungamos com este posicionamento. A amplitude do direito de greve dado pela Constituição não permite concluir por esta delimitação. Tais formas de greves assumem características jurídicas ao servirem de meios eficazes de efetivação dos direitos sociais. Uma greve de fome de obreiros que se recusam a comer no refeitório da empresa em protesto contra refeições de baixa qualidade possui nítido caráter jurídico, não se sustentando a alegação de "dissemelhança jurídica". Da mesma maneira a greve de consumidores, que deixam de comprar produtos de determinada empresa que desrespeita a legislação trabalhista em solidariedade aos trabalhadores. Ademais, o próprio conceito de trabalho deve ser alargado para conferir proteção aos estudantes, que possuem na greve um importante instrumento de pressão ${ }^{40}$. Entretanto, conforme apontado anteriormente, apenas por um critério metodológico estas questões não serão aprofundadas no presente estudo, o que não implica de maneira alguma reduzir a importância jurídica e social a elas inerentes.

Estabelecidas tais conceituações jurídicas, imperativo expor aquilo que se pretende como um verdadeiro direito de greve. Trata-se de uma proposta de texto

\footnotetext{
${ }^{37}$ Petição No 9.409 - DF (2012/0172028-3), Brasília/DF, 16 de agosto de 2012, Relator Ministro Napoleão Nunes Maia Filho.

${ }^{38}$ Ora, como se falar de greve sem "perturbações no desempenho de quaisquer atividades"? Se este fosse em critério para decretar abusividade da greve, esta imediatamente deixaria de ser um direito.

${ }^{39}$ Ramalho, Maria do Rosário Palma. Da Autonomia Dogmática do Direito do Trabalho. Coimbra: Almedina, 2000. Pp. 864/865.

${ }^{40}$ Pretende-se aqui uma utilização do conceito de "estudar" da maneira como é concebido na França, aonde se utiliza o verbo trabalhar para o ato de estudar, como se estudar fosse espécie dentro do gênero trabalhar. Desta maneira, assim como "ensinar", "tornear" ou "projetar" são verbos que designam especificamente uma modalidade de trabalho, "estudar" também o é.
} 
submetido à discussão na Assembleia Constituinte de Portugal que definia a greve como "um direito dos trabalhadores na sua luta pela construção de uma sociedade que ponha fim à exploração do homem pelo homem, na defesa do direito ao trabalho, à remuneração pelo trabalho, às condições de trabalho e aos direitos adquiridos pelo trabalho"41.

\section{2 - Breve crítica à Lei 7.783/89}

Necessária a crítica à Lei 7.783/89. Não seria possível prosseguir com um estudo sobre o direito de greve sem um posicionamento crítico sobre esta lei, sob risco de incorrer em um consentimento implícito com sua plena constitucionalidade, o que seria inadmissível. Desta maneira, pretendemos apresentar de forma breve nosso posicionamento sobre a lei de greve para que o leitor compreenda e pondere sobre nossa visão sobre a questão.

A Constituição, em seu artigo $9^{\circ}$, estabeleceu uma concepção ampla do direito de greve, transferindo aos trabalhadores a responsabilidade para decidir o momento e a forma de deflagração, bem como as reivindicações que buscam conquistar ${ }^{42}$. Foi delegada à lei ordinária apenas a definição dos serviços e atividades essenciais, além do tratamento das necessidades inadiáveis da comunidade, nos exatos termos do parágrafo $1^{\circ}$ do artigo $9^{\circ}$.

Logo, caberia à lei ordinária apenas tratar destas questões delimitadas pela Carta Magna. Entretanto, verifica-se que a Lei 7.783/89 é um compêndio de limitações ao exercício do direito de greve. Trata-se de limites indevidos que ferem o artigo $9^{\circ}$ da Constituição.

A Constituição possui formas legislativas específicas para autorizar a restrição dos direitos que prevê. "Na forma da lei", "a lei definirá", "salvo nos casos definidos em lei”, "salvo nas hipóteses previstas em lei" são expressões que o constituinte utilizou para delegar à legislação infraconstitucional a limitação e especificação de um direito constitucionalmente garantido. $\mathrm{O}$ artigo $9^{\circ}$ não possui nenhuma expressão sujeitando sua forma, finalidade ou exercício a normas específicas. A constituição tratou portanto de forma definitiva a delimitação do conceito de greve, não permitindo restrições.

\footnotetext{
${ }^{41}$ Ramalho, Maria R. P. Lei da Greve. Lisboa: Lex, 1994. Pag.108

${ }^{42}$ Ao leitor mais impaciente, peço desculpas por citar mais uma vez o texto legal, mas já adianto que não será a última vez. Não se trata de recurso desnecessário, pois embora o texto legal seja de uma clareza estonteante, as inúmeras violações interpretativas nos obrigam a reiterar seu conteúdo diversas vezes ao longo de toda esta obra.
} 
Desta forma, a Lei 7.783/89, ao fixar restrições ao direito garantido no artigo $9^{\circ}$ da Carta Magna, o faz de forma inconstitucional. Não pode mera lei ordinária, cuja aprovação exige apenas a maioria simples de votos, impossibilitar o exercício de direito constitucional, direito este que inclusive reveste-se de caráter fundamental em nosso ordenamento. Como aponta José Afonso da Silva, "a melhor regulamentação do direito de greve é a que não existe. Lei que venha a existir não deverá ir no sentido de sua limitação, mas de sua proteção e garantia" ${ }^{43}$.

Contudo, em que pese a crítica exposta, para os fins deste trabalho se admitirá didaticamente a aplicabilidade da Lei 7.783/89. Não se pretende aqui, reitere-se, reconhecer implicitamente a constitucionalidade da lei de greve. Se no presente trabalho admitimos a aplicabilidade desta lei, isto ocorre somente para fortalecer nossa posição sobre a possibilidade política da greve.

O que se pretende demonstrar é que, mesmo sob o viés extremamente restritivo imposto ao direito de greve pela lei de greve, a finalidade política de uma greve reveste-se de plena legalidade. Busca-se assim demonstrar que, independentemente do posicionamento do leitor sobre a constitucionalidade da Lei 7.783/89, a greve não pode ser limitada em decorrência de finalidades políticas.

\section{3 - Natureza jurídica da greve}

A historicidade do direito de greve nos apresenta três interpretações da natureza jurídica do ato de greve. Metodologicamente pode-se definir a greve como um delito, como uma liberdade ou como um direito. Esta classificação deriva da maneira como o Estado e suas leis tratam a questão da greve, variando conforme se altera a conjuntura política, econômica e social.

Em geral a natureza jurídica da greve nos é apresentada como uma evolução natural, que se inicia como delito nos regimes autoritários, passa a ser considerada uma liberdade com o início do liberalismo e que, no auge de sua evolução, passa ser tratada um direito nos modernos estados democráticos de direito.

O maior problema desta concepção naturalista da evolução da greve é que através dela se abstrai o papel relevante que tiveram os trabalhadores para estas mudanças,

${ }^{43}$ DA SILVA, José Afonso. Op. cit., p.305. 
negando a historicidade dos movimentos de luta dos trabalhadores para a evolução da legislação grevista. As alterações da natureza jurídica da greve não devem ser vistas como fruto de uma maturação decorrente do simples passar do tempo e da evolução de nossos legisladores, mas sim através da ótica histórica da luta dos trabalhadores contra os interesses das classes dominantes.

Não se deve tampouco ver as definições metodológicas como conceitos absolutos. Evidente que existem zonas nebulosas entre estes três conceitos; atualmente, por considerar a proibição da greve um ato antidemocrático do governo, muitas constituições a consideram um direito, embora na prática ela seja abordada como um delito. Contudo, esta reflexão será realizada em momento oportuno. Desta maneira, não se pode ignorar a capacidade do próprio sistema econômico de alterar os conceitos da natureza de sua legislação de greve ao sabor de suas necessidades. A confrontação destes conceitos com a legislação deve ser feita sempre de forma crítica em análise do caso concreto.

Ainda hoje, apesar da maioria da doutrina considerar a greve como um direito, algumas modalidades deste instituto ainda não o são; é o caso do exercício de greve com fins políticos, que é considerado, inclusive pela jurisprudência (que será oportunamente apresentada em capítulo específico) como sendo uma liberdade. Pode-se citar também o caso das greves com ocupação do estabelecimento, que ainda hoje são consideradas delitos.

A greve como delito marcou o início da formação da classe trabalhadora. Sob a ótica contratualista clássica, a greve era um meio ilegal de pressionar o empregador. Isto porque estas pressões coletivas dos trabalhadores desrespeitavam a "livre vontade" individual de cada trabalhador como fornecedor de mão de obra. Ademais, as greves eram vistas como uma interferência indevida na entidade denominada "livre mercado".

A positivação sobre a greve ocorria no código penal. Assim, a política econômica da época se resguardou no arcabouço jurídico para assegurar a ilegalidade de qualquer movimento coletivo dos trabalhadores em busca de melhores condições de vida. Esta constatação história facilita a percepção de como a influência política e econômica sempre se mantém indissociáveis quanto ao tratamento jurídico das formas de organização dos trabalhadores e ao exercício da greve, sobretudo na contemporaneidade. Como aponta Pachukanis: 


\begin{abstract}
"O direito igualmente, em suas determinações gerais, o direito enquanto forma, não existe apenas no cérebro e nas teorias dos juristas especializados. Ele possui uma história real, paralela, que não se desenvolve como um sistema de pensamento, mas como um sistema particular que os homens realizam não como uma escolha consciente, mas sob a pressão das relações de produção" ${ }^{\text {"4 }}$.
\end{abstract}

A concepção de greve como liberdade originou-se com a supressão, pelos Estados liberais, das normas de direito penal que puniam os movimentos grevistas. Contudo, neste momento os Estados se posicionavam como meros espectadores, não podendo identificar a greve de modo algum com as chamadas "liberdades públicas" - tais como a liberdade de contratar, a liberdade de culto e a liberdade de ir e vir - pois neste caso não havia qualquer garantia estatal para a concretização e efetivação desta "liberdade".

A greve como direito surge com a evolução do Estado social, passando a ser objeto de uma positivação protetiva, que garante aos trabalhadores a possibilidade de executar paralisações. Assim, a greve só passa a ser garantida efetivamente com o seu reconhecimento como um direito dos trabalhadores, assegurando-lhes formas de exercitar a greve sem prejuízos ao seu trabalho de às suas liberdades individuais.

Embora no Brasil a greve só possa ser considerada um direito com a promulgação da Constituição de 1946, já dizia Evaristo de Moraes, em 1905, que "pela lei penal vigente no Brasil, o direito de greve está plenamente reconhecido. Assim como um operário pode isoladamente deixar de trabalhar, muitos operários têm o direito de recusar o esforço dos seus braços ao chamamento e às necessidades dos patrões. Nem seria compatível com um governo republicano a negação desse direito, que deriva das condições econômicas do nosso tempo"45.

Embora ainda haja desrespeitos e violações ao direito de greve - inclusive por parte dos juristas, como se verá mais a frente - pode-se considerar a greve atualmente como um direito, pois é assegurada por lei, que garante sua realização, disciplina seu conteúdo e estabelece seus limites perante outras normas, assim como é objeto de acordos coletivos.

\footnotetext{
${ }^{44}$ PACHUKANIS, A teoria geral do direito e o marxismo. Rio de Janeiro, Renovar, 1989, p.35.

${ }^{45}$ MORAES, Evaristo de. Op. Cit. pp. 59/60.
} 
Pode-se expor o seguinte julgado, no qual a relatora descreve a a natureza jurídica da greve e suas consequências:

00634-4200-400-00-00-9
JULGADO EM 14/04/2004, POR MAIORIA

PUBLICAÇÃO: DORJ DE 27/05/2004, P. III, S. II, FEDERAL

RELATOR: JUÍZA MARIA HELENA MOTTA

ÓRGÃO: SEDC

GREVE. DISSÍDIO COLETIVO.

DisSídio COLETIVO. GREVE. A CONSTITUIÇÃO FEDERAL VIGENTE, EM SEU ART. 9 ${ }^{\circ}$, CONSAGRA O DIREITO DE GREVE, CABENDO AOS TRABALHADORES DECIDIR SOBRE O MOMENTO IDEAL E OS INTERESSES QUE DEVEM LEVÁ-LOS A EXERCÊ-LO. TRATA-SE DE UM INSTRUMENTO CONFERIDO À CLASSE TRABALHADORA, QUE SE TRADUZ NA INDISPONIBILIDADE DE SUA FORÇA DE TRABALHO, ÀQUELE OU ÀQUELES QUE A UTILIZAM PARA A CONSECUÇÃO DE SEUS OBJETIVOS ECONÔMICOS. MEIO DE PRESSÃO LEGÍTIMO, É UTILIZADO PARA, NÃO SÓ ESTIMULAR A NEGOCIAÇÃO COLETIVA, COMO TAMBÉM PARA OBTER MELHORES CONDIÇÕES DE TRABALHO E GANHOS SALARIAIS. TANTO QUE A PARTICIPAÇÃO EM GREVE COMO MEIO DE LUTA PARA SUSTENTAR UMA REIVINDICAÇÃO NÃO AUTORIZA A RUPTURA DO CONTRATO DE TRABALHO DOS EMPREGADOS QUE A ELA ADERIREM, DO QUE RESULTA FLAGRANTE E CONSEQUÊNCIA LÓGICA, O RECONHECIMENTO DE TAL INSTRUMENTO COMO UM DIREITO.

Apesar do reconhecimento da greve como um direito, não são raros os ataques a este instituto. Estes ataques ocorrem sempre de maneira a restringir o direito de greve e encarcerar seu exercício a limites rígidos e facilmente controláveis. São raros aqueles que defendem uma abolição do direito de greve. Isto porque a positivação da greve é um meio de assegurar a previsibilidade de ações, requisito fundamental para o desenvolvimento do capitalismo moderno ${ }^{46}$. Segundo a lógica econômica liberal, a greve como direito pode ser enquadrada e limitada sem afetar a aparência democrática da sociedade. Excluir o direito de greve seria assumir uma posição ditatorial e ainda assim ser

${ }^{46}$ SENNETT, Richard. A cultura no novo capitalismo. Rio de Janeiro: Record, 2011, p.26-29 
obrigado a lidar com os eventuais conflitos coletivos de trabalho, que por serem ilegais teriam uma deflagração muito mais conflituosa. Assim, a greve como direito é inegavelmente interessante aos detentores dos meios de produção.

Ademais, a greve-direito se encontra inserida na lógica de mercado do sistema neoliberal, como bem aponta Roberto A. O. Santos ${ }^{47}$ :

\begin{abstract}
Ora, a greve como direito tem por fim afirmar que os 'vendedores' da 'mercadoria' estão dispostos a armazená-la temporariamente, privando os 'compradores' da oferta da sua força-de-trabalho, a fim de forçar o aumento do preço ou a mudança de condições de uso dessa 'mercadoria'. Trata-se de uma prática inteiramente compreensível sob o ponto de vista ortodoxo, uma estratégia da luta mercantil de amplo emprego no cotidiano dos negócios com as mercadorias em geral. A rejeição da greve-direito constituiria, portanto, uma contradição lógica irremediável da política do capital, uma postulação de assimetria sem qualquer justificativa dentro dos pressupostos da proposta igualitária clássica da burguesia.
\end{abstract}

Em afronta a um dos mais importantes princípios sociais, atualmente o trabalho humano é tratado como mercadoria de comércio. Contudo, o desrespeito a um princípio não nega sua validade. Como bem ensina Souto Maior ${ }^{48}$, ante tal prática em sentido contrário não se deve reconstruir o princípio, mas buscar a reconstrução da sociedade, sem perder de vista os limites estruturais do Direito na produção desse resultado. Neste sentido, afirma o professor que a enunciação do princípio retém sua relevância ainda que seja para produzir frustração frente à realidade, pois a frustração impulsiona a ação em busca do direito.

Desta maneira, em nosso atual estagio de desenvolvimento econômico a força de trabalho é tratada como mercadoria de comércio, da mesma maneira que a energia elétrica, a matéria-prima e o produto final. Mas o trabalho encontra-se em enorme desvantagem econômica em relação às demais mercadorias. Enquanto o patrão pode estocar seus produtos à espera de melhores preços e diminuir a produção de forma ordenada, percebe-se "uma desvantagem estrutural da força de trabalho no mercado, pois o

\footnotetext{
${ }^{47}$ SANTOS, Roberto A.O. Uma contribuição sociológica à renovação da teoria jurídica da greve. In Revista da Academia Nacional de Direito do Trabalho. São Paulo: LTr, 1993. P.124.

${ }^{48}$ MAIOR, Jorge Luiz Souto.Op. cit., p.551-572.
} 
lado da oferta não tem como controlar a sua própria quantidade de maneira estratégica"49, uma vez que o empregado se vê obrigado pelas circunstâncias sociais a vender seu trabalho como mercadoria imediatamente, não podendo aguardar um momento de "valorização".

Defende Claus Offe que "as opções estratégicas que, de outro modo, são acessíveis aos vendedores das outras mercadorias, no caso da 'mercadoria' força-detrabalho devem ser facilitadas e garantidas desde o início pela regulamentação política"50.

Assim, mesmo com o crescimento dos obstáculos para a deflagração de greves, principalmente devido ao "novo" modelo de organização da economia mundial decorrente da globalização dos capitais produtivos e especulativos, a greve mantém sua natureza jurídica como sendo um direito inerente aos trabalhadores.

Sendo a greve um direito, a concepção jurídica da greve só pode ser entendida dentro do caráter protetivo desse direito para os trabalhadores. A limitação da greve após sua concepção como direito, trazendo mais restrições do que quando era tratada como liberdade, é um retrocesso deste caráter protetivo pretendido com a positivação. Não faz sentido a classificação da greve como um direito senão para conferir aos trabalhadores uma proteção maior do que aquela que eles possuíam quando a greve era uma liberdade. É sob esta ótica que abordaremos o presente trabalho.

\section{4 - Greves atípicas}

Para o desenvolvimento do presente trabalho é necessário tratar da questão das greves atípicas no ordenamento pátrio. Esta necessidade decorre do fato de que em muitos casos o critério político que reveste uma greve é tirado de foco nos julgamentos de nossos tribunais, que recorrem à decretação da abusividade apriorística da greve em decorrência de sua atipicidade para pôr fim ao processo judicial.

Ademais, a doutrina majoritária considera as greves atípicas abusivas sustentando-se no texto legal. O que se pretende também é refutar esta visão e demonstrar que a legislação abarca estas modalidades de greve, revelando que a classificação das greves atípicas como sendo abusivas é resultado de uma escolha política dos aplicadores do direito.

\footnotetext{
${ }^{49}$ OfFE, Claus, Capitalismo desorganizado. São Paulo: Brasiliense, 1989. P.27.

${ }^{50}$ Ibidem, p.29.
} 
Além disso, é de suma importância a análise destas modalidades grevistas, pois como bem nota Santiago Perez Del Castillo, as formas atípicas de greve vem tomando lugar perante as formas típicas, em que a luta é lateral e não mais frontal ${ }^{51}$.

O aumento destas formas alternativas de luta é muito bem explicado por Márcio Túlio Viana, que considera este fenômeno como uma consequência da própria “conjuntura socioeconômica, que vem rompendo o equilíbrio entre o prejuízo causado a cada um dos atores sociais pela greve típica". E continua, concluindo que "num quadro de salários aviltantes, alta rotatividade de mão de obra e baixa qualificação profissional, fazer greve passa a ser um risco muito maior do que sofrer greve" ${ }^{, 52}$.

Por ser um ato estratégico que visa contrapor as complexas formas de prestação de serviços, a greve não pode ser limitada a um único e simples modelo. A anatomia da forma de greve deve ser suficientemente flexível para acompanhar e contrapor as constantes mutações impostas ao modelo de produção. Desta maneira, com a variação e evolução constante na forma de realização da greve, o movimento obreiro poderá agir de forma eficaz na defesa e promoção de seus interesses.

Quanto à licitude das formas atípicas de greve, há um consenso na doutrina de considerá-las sempre ilícitas sob o argumento de que haveria uma suposta quebra do princípio da boa-fé, que deve ser mantido mesmo durante o conflito coletivo, além do fato de não haver qualquer previsão legal quanto a esta matéria, que foge do modelo positivado.

Primeiramente, não se pode julgar de antemão as greves atípicas com base na não previsão legal. As greves chamadas atípicas são variações do modelo tradicional de greve, mas que não possuem de maneira alguma um caráter contra-legen; ela não tem qualquer vedação legal e se sustentam pela própria positivação da greve.

As formas de greve se aprimoraram da mesma maneira e como reflexo da modificação dos métodos de produção e contratação, como modo de não perderem sua eficácia. Deve-se reconhecer estas mudanças e analisar os fatos da realidade social com base nas normas legais postas, de maneira científica. O problema, neste caso, decorre do fato de que "é sem dúvida muito mais cômodo seguir antigos padrões, estabelecidos de

\footnotetext{
${ }^{51}$ Del Castillo, Santiago Perez. Op. Cit. pp.22-23

${ }^{52}$ VianA, Márcio Túlio. Direito de Resistência. São Paulo: LTr, 1996. p.311.
} 
longa data na praxe forense e nos manuais de doutrina, do que repensar soluções para os quase sempre complicados problemas da interpretação evolutiva das normas legais" ${ }^{, 53}$.

Já sobre a suposta quebra do princípio de boa-fé ${ }^{54}$, há aqui o emprego inadequado deste princípio como meio de deslegitimar as greves atípicas. Não há sustentação jurídica para defender que as greves atípicas quebram o princípio da boa-fé senão através da tautologia. Aliás, a tautologia é um recurso utilizado recorrentemente pelos críticos das greves atípicas e das greves políticas. Isto porque, como aponta Edelman, "a tautologia é o processo último que permite agir sobre o real sem o denunciar" "55.

Desta maneira, afirma a doutrina majoritária que a greve atípica é abusiva porque fere com a boa-fé entre as partes, mas ignora que já havia uma quebra deste princípio contra os trabalhadores, que tiveram suas reivindicações frustradas e foram impelidos a recorrer à greve. Assim, não há que se falar em quebra do principio da boa-fé em decorrência do exercício do direito de greve.

Como reconhece Ildélio Martins, "historicamente, sempre se encontrou nas greves um movimento de reação contra injustiças. Há nelas sempre o anseio de reparação de uma desigualdade que circunstâncias de natureza várias acentuam e desproporcionam",56.

Neste ponto, é interessante a opinião de Márcio Túlio Viana, para quem a licitude da greve atípica depende da natureza do prejuízo provocado junto ao empregador. Serão lícitas, portanto, as greves atípicas que produzam prejuízo da mesma natureza ou de natureza semelhante ao provocado por uma eventual greve típica ${ }^{57}$.

As greves atípicas são portanto meios de adaptação do exercício do direito de greve em contraponto às mudanças estruturais do sistema produtivo, um meio legítimo de assegurar a eficácia deste Direito Social.

\footnotetext{
${ }^{53}$ TheOdoro Júnior, Humberto. Direito e Processo. Belo Horizonte: Del Rey, 1996. P.34.

${ }^{54}$ Caberia aqui um questionamento mais profundo sobre este princípio, questionando seu significado e extensão. Afinal, o que representa o princípio da boa-fé para o trabalhador na prestação de um contrato de trabalho? Eis uma questão que merece um estudo mais aprofundado de nossos juristas.

${ }^{55}$ EDELMAN, Bernard. Op. cit., p.35

${ }^{56}$ MARTINS, Ildélio (org.). Temas de Direito do Trabalho - Direito do Trabalho na Crise. Poder empresarial. Greves Atípicas, IV Jornadas Luso-hispano-brasileiras de Direito do Trabalho. Coimbra: Coimbra, 1990. p.489

${ }^{57}$ ViANA, Márcio Túlio. Op. Cit. p.318.
} 
A noção de greve atípica se desenvolve a partir da interpretação doutrinária do texto legal. Contudo, apesar de não se encaixarem necessariamente dentro de um determinado tipo legal, não há uma proibição às greves atípicas, não podendo estas se caracterizar como ilícitas prima-facie.

Para melhor compreender tal conceito, analisar-se-á a classificação das greves atípicas a partir do mesmo modelo metodologicamente utilizado por Antônio Monteiro Fernandes ${ }^{58}$, que caracteriza a atipicidade da greve através de cinco padrões: quanto ao modo de deliberação da paralisação coletiva, quanto ao modo de manifestação do projeto de paragem, quanto à estrutura da paragem de trabalho, quanto ao modo de abstenção do trabalho e quanto à finalidade ou motivação da greve.

Iniciaremos com a análise quanto ao modo de deliberação da paralisação coletiva. $\mathrm{O}$ artigo $4^{\circ}$ da Lei $n^{\circ} 7.783 / 89$ determina que é competência da entidade sindical correspondente "convocar, na forma do seu estatuto, assembleia geral que definirá as reivindicações da categoria e deliberará sobre a paralisação coletiva da prestação de serviços".

Com isto, entende-se como atípicas todas as greves que não foram objeto de deliberação da assembleia geral ou que não foram deflagradas pelo sindicato, nos termos do artigo supracitado, sendo chamadas de greves espontâneas ou selvagens. Primeiramente, necessário ressaltar que a questão da titularidade do direito de greve é expressa em nosso ordenamento tanto no caput do artigo $10^{\circ}$ da Lei Fundamental quanto no artigo $1^{\circ}$ da Lei 7.783/89, quando expressam que compete "aos trabalhadores decidir sobre a oportunidade de exercê-lo e sobre os interesses que devam por meio dele defender". Ora, não resta dúvida de que os titulares do direito de greve são os próprios trabalhadores.

Contudo, o inciso VI do artigo $8^{\circ}$ da Constituição Federal implanta a obrigatoriedade da participação dos sindicatos nas negociações coletivas de trabalho. A interpretação deste texto legal leva grande parte da doutrina ao entendimento de que a legitimidade para a deflagração de uma greve é apenas do sindicato de trabalhadores.

Entretanto, esta interpretação não nos parece correta, uma vez que o $\S 2^{\circ}$ do artigo $4^{\circ}$ da Lei $7.783 / 89$ preceitua que uma comissão de negociação poderá ser constituída

\footnotetext{
${ }^{58}$ FERnANDES, Antônio Monteiro, Greves Atípicas: Identificação, caracteres, efeitos jurídicos; in Temas de Direito do Trabalho - Direito do Trabalho na Crise. Poder empresarial. Greves Atípicas, IV Jornadas Lusohispano-brasileiras de Direito do Trabalho. Coimbra: Coimbra, 1990. pp.503-504.
} 
pela assembleia geral dos trabalhadores, e que esta comissão poderá deliberar sobre a paralisação coletiva da prestação de serviços, no caso de falta de entidade sindical. Esta falta de que trata o texto legal deve ser interpretada não como mera inexistência de sindicato, mas também de sua imobilidade ou insuficiência quanto às necessidades dos trabalhadores e sua fraca atuação como entidade combativa a favor destes.

Toda obra deve ser analisada sistematicamente, e o mesmo deve ocorrer com a interpretação dos direitos sociais. Ora, não seria errado afirmar que o interesse último do legislador ao instituir a obrigatoriedade da assistência sindical foi o de proteger os trabalhadores, garantindo-lhes maior força. Entretanto, ao efetuar uma leitura da norma isoladamente institui-se um contrassenso, uma vez que ao se negar a comissão de negociação como grupo apto a negociar quando a entidade sindical é omissa, acaba-se tendo como resultado justamente aquilo que se pretendia combater com a norma, gerando um grande prejuízo para todos os trabalhadores.

Ademais, sob a ótica principiológica do Direito do Trabalho, a necessidade de deliberação deve ser vista como um critério para garantir a eficácia de um movimento grevista, e não para limitá-lo. A deliberação vislumbra garantir a máxima representatividade democrática dos trabalhadores envolvidos com o movimento e assegurar uma coesão em suas reivindicações, possibilitando ao movimento grevista uma maior força reivindicatória. Se a representatividade e a coesão das reivindicações transparecem no movimento grevista, a necessidade de deliberação prévia fica superada.

Um movimento que se inicia de forma espontânea reflete uma necessidade iminente de manifestação por parte dos trabalhadores ante uma injustiça. Em tais casos, a observação desta burocracia acabaria por inutilizar o exercício do direito, o que é inadmissível. Analisaremos as diferenças entre as abordagens jurisprudências em relação à necessidade de deliberação prévia quando abordarmos os julgados relativos à greve na PUC de São Paulo em 2012 e a greve dos trabalhadores em transporte de Campinas no ano de 1998.

Com relação ao modo de manifestação do projeto de paragem, a atipicidade baseia-se no parágrafo único do artigo $3^{\circ}$ da Lei $n^{\circ} 7.783 / 89$, que determina que "a entidade patronal correspondente ou os empregadores diretamente interessados serão notificados, com antecedência mínima de 48 (quarenta e oito) horas, da paralisação". No caso de "serviços ou atividades essenciais" aplicável o artigo $13^{\circ}$ da mesma lei, que amplia 
o prazo mínimo para comunicação dos empregadores e usuários para setenta e duas horas antes do início da paralisação.

Portanto, caso não ocorra esta notificação, ou caso esta não ocorra de maneira burocrática (como, por exemplo, através de palavras de ordem em uma manifestação pública), ou mesmo no caso de que este pré-aviso seja inferior ao prazo legal aplicável, esta greve é caracterizada como uma greve-surpresa, considerada atípica.

Como visto, a atipicidade de uma greve não lhe imputa um caráter abusivo ou ilegal. Sob a ótica principiológica dos direitos sociais, não podemos interpretar estas normas como meros limitadores ao exercício do direito de greve. Ao contrário, evidente que o objetivo primeiro destes artigos é buscar meios de resolver o conflito antes mesmo da paralisação. Assim, ao conferir ao empregador a ciência do movimento grevista e suas reivindicações, estes artigos objetivam um diálogo conciliatório entre as partes.

Contudo, nem sempre essa conciliação prévia é possível, seja pela necessidade inadiável de deflagração da greve, sob pena de ineficácia, seja por um exercício abusivo do poder patronal que explicite sua rejeição à negociação. Os artigos $3^{\circ}$ e $13^{\circ}$ da Lei 7.783/89 só podem ser interpretados sob esta ótica, sob pena de negação dos princípios basilares do Direito Social.

Desta maneira, reiterando a ideia de licitude das greves atípicas, a ausência de notificação prévia ao empregador não gera abusividade do movimento paredista.

Já a atipicidade em relação à estrutura da paragem de trabalho decorre do entendimento majoritário que considera pressuposto de tipicidade para uma greve a sua prática de forma simultânea e continuada por todos os obreiros que apoiaram o plano de greve. Desta maneira, as chamadas greves rotativas, articuladas e intermitentes enquadramse no conceito de greves atípicas.

Um exemplo de alterações estratégicas na forma de realização de uma greve é a greve rotativa, também conhecida como greve por turnos ou greve articulada. Esta forma de greve consiste na suspensão parcial e sucessiva do labor. A execução da greve, ao invés de ocorrer com a paralisação de todos os trabalhadores ao mesmo momento, se dá de forma alternada, onde somente determinada parcela deixa de trabalhar, de modo que toda a produção reste prejudicada, embora somente uma parcela dos obreiros esteja efetivamente em greve. Pode-se, por exemplo, paralisar alternadamente diferentes etapas de uma linha 
de montagem, de setores de produção inter-relacionados ou setores dependentes para prestação de determinado serviço.

Esta é a forma de greve que exige o maior planejamento e precisão, para que as paralisações sejam devidamente concatenadas de modo a obter o resultado desejado. Não se trata de movimentos únicos, isolados e desconexos, mas sim de uma ação repetitiva e coordenada.

Contudo, apesar da complexidade para realiza-la, a greve rotativa é a que apresenta o efeito mais nocivo para o empregador sem demandar, comparativamente, tanto sacrifício por parte do empregado, uma vez que, ao mesmo tempo em que o empregador tem a obrigação de pagar o salário para os trabalhadores que não estão em greve, estes se veem impossibilitados de realizar seu serviço dada a dependência estrutural relativa ao trabalho que deveria ser desempenhado pelos obreiros paralisados. Assim, além de causar um maior prejuízo, permite a manutenção do movimento por um período mais longo, uma vez que o período de greve não pago é intercalado com períodos de trabalho normal, com o devido recebimento salarial.

Como muito bem observa Sinay, esta forma de "greve fragmentada" constitui de alguma maneira uma "réplica ao trabalho fragmentado, característica da sociedade industrial contemporânea", e continua, "é precisamente nas empresas mais modernas que tamanha organização científica da greve apareceria em primeiro lugar" ${ }^{\prime 59}$.

Muito parecida com a greve rotativa em seu princípio de estrangulamento do sistema produtivo, a greve nevrálgica consiste na suspensão de trabalho de apenas um determinado setor da empresa, mas que é vital para seu funcionamento, decorrendo, portanto, uma paralisação da produção ou da prestação de serviços.

Há também as greves intermitentes, que podem ser definidas como uma "greve fracionada no tempo, que se traduz por uma série de suspensões do trabalho, interrompidas por períodos de retorno" ${ }^{\natural 0}$. Estas suspensões podem ocorrer tanto com a entrada em atraso, com a saída mais cedo ou com paralisações intra-jornada, que podem repetir-se de forma reiterada por vários dias ou até mesmo dentro de uma mesma jornada de trabalho.

\footnotetext{
${ }^{59}$ SinAY, Hélène. Traité de Droit du Travail - La Gréve. Paris: Dalloz, 1966. p.35-37

${ }^{60}$ Del Castillo, Santiago Pérez. Op. Cit. P.342.
} 
Uma grande vantagem deste tipo de greve é a possibilidade de protestar dentro do próprio local de trabalho, na presença de grevistas e não grevistas, o que não ocorre na maioria dos outros tipos de greve.

Quando ao modo de abstenção do trabalho, classificam-se como atípicas as greves nas quais os trabalhadores não abandonam o local de trabalho - as chamadas greves de zelo e greves de braços cruzados. Contudo, apesar de ser patente que a noção jurídica de greve não exige o abandono do local de trabalho, parte da doutrina afirma que estas greves "extravasam claramente dos limites do exercício do direito de greve"61. Trata-se entretanto de afirmação desprovida de sustentação legal, uma vez que estes modos de abstenção do trabalho apenas representam uma evolução no exercício do direito de greve ante as tentativas de enfraquecimento das pressões obreiras por parte dos empregadores.

É o caso da greve de rendimento, na qual diferentemente dos outros tipos de greve os trabalhadores não cessam o trabalho. Nesta modalidade eles diminuem, voluntariamente, a eficácia de seu trabalho, reduzindo a produção em níveis previamente acordados, podendo inclusive ocorrer uma queda total do rendimento do trabalho, no caso dos trabalhadores se manterem nos postos de trabalho sem nada produzirem; é a chamada "greve de braços cruzados". Percebe-se que deve haver, portanto, um minucioso planejamento anterior, para convencionar a exata diminuição do rendimento entre todos os obreiros.

Temos também o caso da greve de zelo. Esta não consiste na paralisação do trabalho; ao contrário, significa um recrudescimento do processo produtivo. Tal greve pode ocorrer tanto através da execução meticulosa e detalhada do trabalho quanto pela estrita observância de todos os regulamentos, seja através do estrito cumprimento de todas as normas internas, da percepção de todas as indicações técnicas, ou da realização cuidadosa de todas as formalidades administrativas, o que acarreta em uma inevitável diminuição produtiva.

Esta modalidade de greve é muito comum em setores nos quais a aparagem encontra diversos obstáculos no poder judiciário, como é o caso da polícia federal, que

\footnotetext{
${ }^{61}$ Ibidem, p.506. (Note-se que resta saber em que preceito baseiam-se os limites supracitados, uma vez que alheios às normas e princípios do Direito do Trabalho. A doutrina utiliza muitos conceitos abstratos, como se fossem dados concretos na tentativa de restringir o direito de greve. Ora, se estas modalidades extravasam os limites do direito de greve, deveria o autor apontar quais são estes limites, o que não o faz.)
} 
encontrou um modo de contornar tal situação através desta modalidade de greve, também chamada de "procedimento padrão".

A riqueza destas formas de exercício do direito de greve consiste no fato de utilizar as estruturas do modo de organização produtiva Toyotista a favor da reivindicação obreira. Isto porque o saber-fazer do trabalhador, que é utilizado pelo patrão como forma de maximizar a produção, é contestado nesta paralisação. O trabalhador deixa de prestar sua perícia adquirida no desempenho da função, trabalhando de forma mecânica conforme regulamentado pelo empregador.

Estas formas de greve, mesmo não representando uma efetiva parada do processo produtivo, muitas vezes são mais eficazes do que se ocorresse esta plena suspensão, pois a prestação coletiva acaba se tornando inapropriadal, seja prejudicando o ritmo de produção, seja afugentando os clientes com as longas filas, anulando assim a atuação dos fura-greves.

Por último, quanto à finalidade ou motivação da greve, consideram-se atípicas aquelas greves que não tenham motivação expressamente profissional, nas quais o empregador não possua capacidade direta de prover as exigências dos trabalhadores, tais como as greves políticas e de solidariedade.

A finalidade como pressuposto essencial para a deflagração da greve decorre do próprio texto constitucional. No artigo $9^{\circ}$, ao assegurar o direito de greve, a Carta Magna incumbe aos trabalhadores a fixação dos interesses que a greve defenderá. Desta maneira percebe-se que a greve é um ato motivado, visando um ou mais objetivos específicos. A finalidade de uma greve diz respeito ao anseio dos trabalhadores, o que estes objetivam com seu protesto. Aponte-se que não há qualquer impedimento na alteração dos objetivos da greve ao longo de sua execução, desde que assim o deseje a coletividade de trabalhadores.

A finalidade a ser perseguida pelos trabalhadores através da greve é, entre todos os pressupostos, aquele que mais gera controvérsias. Esta finalidade é pautada pelo conteúdo reivindicatório apresentado pela coletividade dos trabalhadores. A controvérsia reside nos limites impostos aos trabalhadores para determinar este conteúdo reivindicatório segundo suas estratégias de luta social.

Este ponto é o cerne deste projeto e será tratado de maneira mais aprofundada no capítulo seguinte. 


\section{5 - Atos de greve}

São de grande importância também os diversos métodos de ação coletiva utilizados como instrumento de fortalecimento do movimento grevista. Estes métodos representam meios extremamente relevantes de manifestação social, sendo realizados pelos trabalhadores como forma de complementar e fortalecer um movimento grevista.

Trataremos aqui da ocupação de estabelecimento, dos piquetes e do boicote eis que são os meios mais controversos atualmente utilizados pelos trabalhadores no curso de um movimento grevista. Trata-se de atos que se encontram dentro da esfera do direito de greve, devendo ser considerados como atos de execução deste direito com o objetivo de assegurar sua instrumentalização como meio de pressão em prol das reivindicações dos trabalhadores.

Sendo estes atos inerentes ao exercício do direito de greve, impossível verificar a abusividade apriorística imputada a eles pelos juristas. Criticáveis portanto os grandes obstáculos criados a estes atos coletivos, especialmente pela doutrina e pela jurisprudência, que vedam o exercício destes atos por considerá-los abusivos, conforme veremos a seguir.

\subsection{1 - Ocupação}

Tida como ilícita por grande parte da doutrina brasileira sob alegada ofensa ao direito de propriedade do empregador, a ocupação durante uma greve é, sobretudo e com intensidade maior que os outros atos de greve, uma manifestação simbólica. A ocupação da fábrica pelos trabalhadores representa não somente a impossibilidade de produção, mas também, e neste ponto muito mais perigoso para o empregador, a consciência por parte do trabalhador que aquele local, pelo seu trabalho, de alguma forma também lhe pertence.

Como descreve Simone Weil, poder caminhar livremente dentro de um espaço onde sua atuação sempre foi restrita ao trabalho sob a autoridade de um chefe representa uma verdadeira contestação da hierarquia e divisão do trabalho e o reconhecimento da possibilidade de um modelo diferente de organização ${ }^{62}$.

\footnotetext{
${ }^{62}$ Apud Simone Weil. La condition ouvrière. in H. Sinay. Ob cit. p.43. "Cette grève est en elle-même une joie; une joie pure; une joie mélange. Oui, une joie. J'ai été voir les copains dans une usine où j'ai travaillé il y a quelques mois. Joie de pénétrer dans l'usine avec l'autorisation souriante d'un ouvrier qui garde la porte. Joie de trouver tant de sourires, tant de paroles d'accueil fraternel. Joie de parcourir librement les ateliers où on etait rivé sur sa machine. Joie d'entendre, au lieu du fracas impitoyable des machines, de la
} 
Além disto, a ocupação da empresa não encerra em si um abuso de direito, mas sim a extensão do direito de greve. Uma suposta ilegalidade configurar-se-ia apenas se esta ocorresse de forma violenta, e justamente pelo método empregado - a violência - e não pelo ato em si - ocupação da fábrica. Ressalte-se que a noção de "forma violência" deve ser analisada com cautela, com base no caso concreto, observando-se a proporcionalidade com o ato praticado pelo empregador, uma vez que esta "forma violenta" pode ser apenas a externalização proporcional de um uma violência maior originada pelo próprio empregador.

Valdes Dal-Re desenvolve este ponto de forma muito lúcida:

(...) de início, considerar que toda greve com ocupação de fábrica lesiona forçosamente o direito de propriedade do empresário e justifica intervenções enérgicas voltadas para a desocupação implica renunciar a uma concreta valoração dos interesses em jogo. O argumento, válido nas hipóteses de ocupação em que existia um animus spoliandi, isto é, uma intenção de apropriarse ou de destruir os bens retidos, carece de fundamento nas situações de ocupação pacífica. A objeção, fácil mas simplista, de que a expressão 'ocupação pacífica' encerra uma contradição, já que toda ocupação se efetua sempre com violência, levando-se em conta a oposição expressa ou tácita do proprietário, não aparece suficientemente fundamentada. Para a existência de violência tipificadora do animus spoliandi, não basta uma vontade em contrário do proprietário; é preciso, como observa a jurisprudência italiana mais moderna, que se haja realizado veri e propiatti di violenza materiale o morale. Em outras palavras, a idéia que se quer emitir é a de que não cabe inferir a ilicitude da greve com ocupação, prescindindo da sua finalidade ou motivação. Em tal sentido, a técnica de ocupação pacífica dos centros de trabalho se revela como instrumento auxiliar de uma greve, através da qual se pode, por outra parte, reequilibrar posições contratuais relacionadas com uma negociação coletiva e orientar, por outra parte, a iniciativa privada para fórmulas de maior utilidade social. ${ }^{63}$

Este posicionamento já vem sendo adotado por alguns magistrados brasileiros. Um caso recente que embora advindo da justiça cível merece ser modelo inclusive para os julgados trabalhistas é a decisão do juiz Mauro Iuji Fukumoto no processo $\mathrm{n}^{\mathbf{o}}$

musique... Joie de passer devant les chefs la tetê haute. Joie de vivre parmi ces machines muettes au rythme de la vie humaine."

${ }^{63}$ DAL-RE, Valdes. Limites al derecho de Huelga; apuntes críticos. apud NASCIMENTO, Amauri Mascaro do. Ob cit. P.435. 


\subsubsection{8-2 (UNICAMP x DIRETÓRIO CENTRAL DOS ESTUDANTES /} DCE - UNICAMP com trâmite na $1^{\mathrm{a}}$. Vara da Fazenda Pública de Campinas). Neste processo, que tratou da ocupação do prédio da reitoria da Unicamp pelos estudantes durante um movimento de protestos e reivindicações, assim julgou o magistrado:

(...) de fato, ocupação de prédios públicos é, tradicionalmente, uma forma de protesto político, especialmente para o movimento estudantil, caracterizando-se, pois, como decorrência do direito à livre manifestação do pensamento (artigo $5^{\circ}$, IV, da Constituição Federal) e do direito à reunião e associação (incisos XVI e XVII do artigo $5^{\circ}$ ). Não se trata propriamente da figura do esbulho do Código Civil, pois não visa à futura aquisição da propriedade, ou à obtenção de qualquer outro proveito econômico. A situação em tela não se amolda à proteção possessória prevista nos artigos 920 e seguintes do Código de Processo Civil, especialmente aos critérios dos artigos 927 e 928 para a concessão da liminar. Inegável, por outro lado, que toda ocupação causa algum transtorno ao serviço público - se assim não fosse, pouca utilidade teria como forma de pressão. Há que se ponderar, dentro de um critério de razoabilidade, a importância do serviço público descontinuado pela ocupação, de um lado, e o resguardo dos direitos constitucionais supra mencionados, de outro.

Ademais, mesmo os mais avessos a esta modalidade grevista devem reconhecer que a ocupação do estabelecimento é, senão o mais eficaz, um dos meios mais importantes que se encontram nas mãos dos trabalhadores como medida que vise salvar determinada empresa do abandono, de ameaça de fechamento, de liquidação de bens e como consequência última salvar o seu emprego.

O problema, neste caso - e o problema geral deste tema - é a importância excessiva dada a determinados direitos, tal como o direito de propriedade, tratado muitas vezes como se fosse um princípio superior aos demais princípios jurídicos, atuando indevidamente em detrimento de pressupostos de proteção ao ser humano. Esta visão merece ser duramente combatida, como nos ensina Orione e Souto Maior ${ }^{64}$ :

\footnotetext{
A unidade política sugere, ainda que o sistema seja capitalista, que, no cotejo dos princípios, pelo menos a base fundante dos valores éticos e, mesmo políticos, da
}

\footnotetext{
${ }^{64}$ CORREIA, Marcus O.G. e MAIOR, Jorge L.S. O Que é Direito Social, in CORREIA, Marcus O.G. (org). Curso de Direito do Trabalho. São Paulo: LTr, 2007, vol. I.
} 
sociedade não possa se remeter a um postulado fundante - a propriedade - que é externa ao próprio homem, sob pena de os valores do direito se deslocarem do homem para elemento que não lhe é necessariamente inerente. Assim, se o direito de propriedade pudesse subjulgar todos os demais direitos, passando a ser princípio - e mais sobreprincípio - seria possível se deslocar, indevidamente, a proteção do homem (destinatário do direito) para a propriedade (objeto do direito).

\subsection{2 - Piquete}

Como bem define Orlando Gomes, piquetagem consiste na "organização de grupos de grevistas, que vigiam o ingresso na empresa ou estabelecimento para impedir o acesso dos não-grevistas, e até mesmo na residência destes ou na dos dirigentes da empresa, para exercer pressão ou coação" ${ }^{\text {65 }}$. Contudo, o piquete não se limita a evitar o comparecimento de trabalhadores a um determinado local de trabalho que se encontra em greve; ela pode ter como finalidade convencer os obreiros a tomar parte ou continuar a greve ou boicote, ou mesmo informar ao público e outros empregados a existência de um litígio naquele estabelecimento ${ }^{66}$.

Entre os incontáveis tipos de piquetes, deve-se destacar o chamado "piquete secundário", que é realizado perante determinado empregador não envolvido diretamente no dissídio trabalhista, mas que mantém ligação negocial ou de propriedade com o empregador contra o qual o sindicato se acha em luta.

No piquete figuram como sujeitos ativos todos os participantes do ato em si (e não necessariamente todos os grevistas) e como sujeitos passivos aqueles que se objetiva convencer, sejam eles os empregados, o empregador ou mesmo terceiros que não tem qualquer relação com o movimento grevista.

A legalidade dos piquetes é assegurada pela Lei 7.783/89, que dispõe no artigo $6^{\circ}$, I, que é permitido aos trabalhadores "o emprego de meios pacíficos tendentes a persuadir ou aliciar os trabalhadores a aderirem à greve". Deste texto decorre que, em caso de constrangimento mediante violência ou grave ameaça, o piquete não encontrará respaldo legal sendo que, ao contrário, estará tipificado como crime de atentado contra a liberdade de trabalho, conforme consta no artigo 197, I, do Código Penal.

\footnotetext{
${ }^{65}$ Gomes, Orlando e GotTschalk, Elson. Op. Cit. P.713.

${ }^{66}$ Peterson, Florence. Sindicatos Operários Norte-Americanos. Rio de Janeiro: Agir, 1953. P.301.
} 
Entretanto, é plenamente questionável a possibilidade de alguns trabalhadores desacatarem a vontade democrática da maioria dos obreiros, continuando suas atividades laborativas em detrimento de uma causa coletiva. Para justificar esta proibição, é utilizado o argumento da preservação da "liberdade de trabalho", que se sustenta no princípio da "liberdade individual". Contudo, este argumento não encontra respaldo no conjunto dos direitos fundamentais e do Direito do Trabalho, pois seria uma negação da preponderância da autonomia coletiva perante a autonomia individual, sendo que, neste caso, esta defesa da liberdade individual não parece ser forte o suficiente para suplantar o princípio democrático e social que fundamentam nossa Constituição.

Analisando-se a evolução dos Estados no século XX, percebe-se que o liberalismo cedeu lugar ao controle social do capitalismo, ainda que de forma sutil. Apesar da discussão sobre eventual retroação deste processo ser assunto muito em voga atualmente, é patente que foi abarcado por nossa Constituição a Justiça Social como compromisso do Direito.

Neste sentido, podemos citar Rogério Coelho ${ }^{67}$ :

\begin{abstract}
A Constituição Brasileira de 1988 segue este novo rumo; de um lado reconhece as categorias profissionais como sujeitos de direitos e dá garantias para o seu exercício; de outra parte, afirma que a ordem social tem como objetivo o bem estar e a justiça social (art.193). Nestas condições, é possível concluir que não tem abrigo no moderno Direito Constitucional Brasileiro o dogma da liberdade individual com raízes kantianas ${ }^{68}$, e que - em consequiência - o exercício do direito individual de trabalhar fica inibido pela decisão coletiva de suspender o trabalho. A autonomia da vontade individual cede ante a autonomia da vontade coletiva, manifestação autêntica de democracia. Assim sendo, o ato de trabalhar, quando a categoria profissional decide pela greve, é um ato contrário ao Direito, um ato ilícito, portanto.
\end{abstract}

Apesar da doutrina majoritária ainda ser contrária à piquetagem, é inegável que este é um complemento essencial ao movimento grevista, que objetiva inicialmente

\footnotetext{
${ }^{67}$ CoElho, Rogério. A greve, os Grevistas e os Não Grevistas, in Revista LTr noo7 nov/89. São Paulo: LTr, 1989. P.344.

${ }^{68}$ O próprio autor esclarece este dogma: “... o conceito kantiano de liberdade tem como pressuposto um conceito de homem como um ser fragmentado e atomizado, incapaz se somar-se a outros homens na busca da felicidade; eis que sua vontade não se estriba em qualquer principio comum”. Ibidem, p.344.
} 
persuadir os trabalhadores que não aderiram ao movimento a fazê-lo e convencer aqueles que já o fizeram a não desistirem da luta, além de servir como meio de pressão perante o empregador e de convencimento da opinião pública, buscando o fortalecimento da solidariedade entre os trabalhadores e aqueles que não estão diretamente envolvidos com a greve.

\subsection{3 - Boicote}

O termo boicote tem sua origem no nome do capitão Charles Cunningham Boycoot, um proprietário de terras que foi submetido a um isolamento e privado de manter relações sociais durante a revolução agrária irlandesa, como forma de punição imposta pela comunidade trabalhadora em decorrência dos injustos maus-tratos dispensados aos seus subordinados. Os obreiros se reuniram e formaram uma coalizão, abandonando as terras e o gado de Boycoot, além de incitar outros camponeses e fornecedores a fazerem o mesmo. Sem mão de obra disposta a vender seu trabalho, o dono de terras se viu obrigado a abandonar o lugar.

Esta tática foi posteriormente adaptada e utilizada como arma nos conflitos coletivos de trabalho; contudo não se deve confundir a boicotagem com os diversos tipos de greve, pois é um modo de ação diverso, embora possa ocorrer conjuntamente com esta.

Metodologicamente, faz-se a divisão entre boicote primário e boicote secundário. O boicote primário é aquele dirigido diretamente contra quem a tática está sendo utilizada; há o boicote praticado diretamente pelos efetivos consumidores, realizado seja contra um produto, uma fábrica, um grupo econômico ou todo um setor da indústria. Já o boicote secundário traduz-se como a pressão ou conscientização realizada perante terceiros para que estes deixem de consumir aquilo que se pretende boicotar; serve, basicamente, par efetivar a boicotagem primária, agregando outros setores do conjunto social para fortalecer este meio de pressão.

A boicotagem não necessariamente se dirige à negação de compra de mercadorias. Ela pode ocorrer da mesma maneira que se deu com a pessoa que deu origem ao vocábulo, quando trabalhadores organizados acordam por não mais oferecer seus serviços à determinada empresa. Pode-se citar, neste sentido, a definição dada por Alfredo Ruprecht, que expõe o boicote como um "acordo dos trabalhadores, geralmente de origem 
sindical, de proibir trabalhar com determinado empresário; quer dizer que se interfere na atividade profissional de uma pessoa" ${ }^{, 69}$.

Há também uma forma oposta de pressão, utilizada especialmente nos EUA e denominada de marca sindical, ou label. Estas marcas são colocadas nas embalagens de determinados produtos como meio de sinalizar que aquela determinada empresa mantém "relações pacíficas" com seus empregados, funcionando como estímulo para o consumo daquele determinado produto em detrimento de outro, que não possui esta marca e que deve ser boicotado ${ }^{70}$.

Deve-se observar que não há impeditivo algum em nosso ordenamento quanto à prática da boicotagem, traduzindo-se como ação sindical plenamente válida; o artigo 198 do código Penal pátrio trata apenas dos casos de boicotagem violenta, o que de maneira alguma condiz com as práticas apresentadas de boicotagem. Contudo, apesar das facilidades existentes atualmente de conscientização e informação, principalmente através da internet, as ações de boicote se mostram muito enfraquecidas devido, principalmente, à grande força da propaganda nos grandes meios de comunicação de massa.

\footnotetext{
${ }^{69}$ RuPRECHT, Alfredo J. Relações Coletivas de Trabalho. Trad. Edílson Alkmin Cunha. São Paulo: LTr, 1995. P.855

${ }^{70}$ Gomes, Orlando e GotTschalk, Elson. Op. cit., p.713.
} 


\title{
3 - GREVE POLÍTICA
}

\author{
A um trabalhador perguntaram, no tribunal, se ele iria fazer o julgamento \\ sagrado ou o profano. Ele respondeu: "Estou desempregado". "Isto não foi \\ simplesmente uma distração", disse o Sr. K. "Com essa resposta ele deu a \\ entender que se achava numa situação em que tais perguntas, e talvez todo o \\ processo judicial, não têm mais sentido". \\ Bertold Brecht - Histórias do Sr. Keuner
}

Primeiramente, algumas explicações devem ser feitas. Neste capítulo apresentaremos os conceitos mais recorrentes sobre a greve política. Não se trata de admitir de forma acrítica as divisões estabelecidas pela doutrina, mas sim de apresentá-las de forma que seja possível fazer referência a estes posicionamentos quando sustentarmos a legalidade da greve política ou quando analisarmos as decisões judiciais sobre esta questão.

Desta maneira, não vamos expôr aqui um conceito de "greve política" a ser tomado como correto. Isto porque seria impossível fazê-lo de forma adequada sem estudar com profundidade o próprio conceito de política, o que extrapolaria a abrangência desta dissertação. Assim, não é objetivo deste trabalho fixar o conceito de política no estudo do direito de greve, mas sim apontar os equívocos cometidos por nossos tribunais quando analisam as greves de cunho político, demonstrando que os conceitos atuais precisam ser revistos.

Para isto, na primeira parte deste capítulo trataremos dos conceitos mais utilizados pela doutrina e pela jurisprudência dominantes para definir "greve política". Em seguida abordaremos as diferenças de tratamento em relação às greves políticas com base nas posições da teoria ampliativa e na teoria restritiva do direito de greve.

Estas duas primeiras partes servirão de suporte para a terceira parte, na qual criticaremos tais visões e será abordada a licitude da greve política. Todo o exposto será de grande valia para adentrarmos o capítulo seguinte deste trabalho, onde analisaremos os julgados de nossos tribunais a respeito deste tipo de greve. 


\section{1 - Conceito de greve política}

Neste capítulo exploraremos de forma breve os conceitos de greve política mais utilizados pelos juristas (sobretudo por nossos magistrados) de forma a expô-los à nossa crítica. Reiteramos que este trabalho não busca trazer uma resposta definitiva à problemática da greve política, mas sim demonstrar que o conceito atual é insuficiente e deve ser superado.

Uma separação metodológica muito utilizada nas decisões judiciais corresponde àquela apresentada por Pierre-D. Ollier ${ }^{71}$ e Hélène Sinay ${ }^{72}$, que classificam as finalidades das greves em quatro categorias: econômica, profissional, sindical e estritamente política.

Segundo estes autores franceses, a greve com finalidade econômica representa um movimento de "crítica da gestão, privada ou pública, local ou regional" local, podendo estar aliada a um projeto de planejamento econômico diferente do modelo econômico e financeiro dos poderes públicos. Sinay cita que na década de 60 na França, "nas regiões economicamente subdesenvolvidas foram declaradas greves para protestar contra os licenciamentos e para obter uma melhor distribuição econômica local ou regional" 74 .

Já a greve com finalidade profissional é definida como aquela que pretende protestar por melhorias da relação de trabalho, seja por diminuição de horas de trabalho, seja por aumento salarial, seja por melhorias nas condições e local de trabalho, entre tantas outras reivindicações possíveis no que diz respeito à relação empregador-empregado. Geralmente greves com esta finalidade ocorrem como meio de pressão para a realização ou implantação de um acordo coletivo.

Apontam que as greves com finalidade sindical são movimentos que visam garantir ou ampliar os direitos sindicais existentes, ou assegurar os direitos de greve existentes. Como exemplo, incluem nesta categoria greves de trabalhadores contra o modelo de organização sindical existente.

\footnotetext{
${ }^{71}$ OLLIER, Pierre-D. Le droit Du travail. Paris: Librairie Armand Colin, 1972.

${ }^{72}$ SINAY, Hélène. Op. Cit pp.54/61.

${ }^{73}$ Ollier, Pierre-D. Op. Cit.

${ }^{74}$ SINAY, Hélène. Op. Cit. p.54.
} 
A greve com finalidade estritamente política é descrita como aquela que não possui nenhuma base profissional, visando protestar contra atos do governo e de órgãos do poder público ou privado. Pierre-D. Ollier cita como exemplos de greves estritamente políticas na França as greves contra as guerras da Indochina e da Argélia ou contra a execução do casal Rosenberg.

Outra classificação também muito utilizada separa as greves em apenas duas categorias: greves econômico-profissionais e greves estranhas ao estrito contrato de trabalho. Segundo Mauricio Godinho Delgado, as greves econômico-profissionais circunscrevem-se "às fronteiras do contrato de trabalho, ao âmbito dos interesses econômicos e profissionais dos empregados, que possam ser, de um modo ou de outro, atendidos pelo empregador" ${ }^{, 75}$. Representam assim os interesses típicos do contrato de trabalho.

Já as greves estranhas ao estrito contrato de trabalho são exemplificadas através das greves políticas e das greves de solidariedade. A peculiaridade de uma greve que possibilita sua adjetivação como política decorre da apreciação das finalidades perseguidas e contra quem ela se dirige. Enquanto na greve "tradicional" as reivindicações possuem cunho estritamente profissional, necessariamente atrelado à relação de trabalho existente entre trabalhadores e empregadores, na greve política amplia-se esta abrangência.

Desta maneira, a greve política seria aquela dirigida contra os poderes públicos, tendo como objetivo protestar contra decisões do governo ou pressionar órgãos governamentais para que tomem ou deixem de tomar determinada decisão. Também são consideradas políticas as greves dirigidas contra o próprio empregador, mas em protesto a decisões que não tenham ligação direta com o estrito contrato de trabalho. Neste caso se encaixa, por exemplo, a greve na Pontifícia Universidade Católica de São Paulo em 2012, como veremos adiante.

Evaristo de Moraes Filho afirma que "a greve não é mais somente um modo de defesa dos interesses dos trabalhadores, mas o modo de emancipação e promoção da classe operária", e continua, citando o professor alemão H.J. Kaiser, dizendo que "a greve política não se distingue necessariamente da greve profissional por seu conteúdo nem por suas motivações (...) nem necessariamente pelos meios, nem mesmo por sua finalidade, mas

${ }^{75}$ DELGADO, Mauricio Godinho. Curso de Direito do Trabalho. 11 a edição. São Paulo: LTR, 2012, p.1429. 
essencialmente por suas reivindicações. A greve política não se dirige somente contra o empregador, mas direta ou indiretamente contra a comunidade ou contra o Estado"76.

Com relação às greves de solidariedade, estas são descritas como greves nas quais os trabalhadores buscam demonstrar seu apoio à determinada reivindicação realizada por outro grupo de trabalhadores ou para fortalecer outra greve já em execução, sem que haja necessariamente um interesse comum entre as categorias.

Para finalizar, necessário expor a crítica produzida por Edelman. Para este autor francês a separação construída pela doutrina separando o direito privado (profissional) e o político é falaciosa.

Estudando um julgamento proferido pela Cour de cassation francesa, Edelman expôs a complexidade entre a distinção entre político e privado que se adéqua à questão aqui debatida. Segundo ele:

Pelo subterfúgio de tais regras jurisprudenciais, chegar-se-ia a dar à instância política (O Estado) o poder de decidir, no direito interno, tanto aquilo que é privado como aquilo que não o é. Numa tal hipótese, mostrar-se-ia que uma parte importante do Direito - e, nomeadamente, o Direito do Trabalho - escaparia à técnica (protetora quando adquirida por meio de dura luta) do direito. No fim desta análise 'concreta' não podemos saber como e em nome de quê poderíamos distinguir os direitos políticos dos direitos privados. Esta insuficiência remete para a questão da sua insuficiência. A passagem à teoria torna-se necessária. ${ }^{77}$

Neste sentido, afirma que esta separação é resultado de um processo ideológico como forma de contenção e delimitação dos campos de atuação dos cidadãos. Esta separação oculta o caráter político do direito e dificulta a contestação política do direito e a contestação jurídica da política.

No caso da greve, esta separação teria o papel de imobilizar as ações realmente efetivas de um movimento de trabalhadores. O que os trabalhadores poderiam pleitear diretamente lhes é colocado como possível mediante barreiras que, na prática, são intransponíveis. Ao adotar a ideia de que as leis regulam inteiramente a questão da greve, os trabalhadores são pressionados a não agir contra as esferas políticas. A crítica do direito

\footnotetext{
${ }^{76}$ MORAES FILHO, Evaristo de. Op. Cit p.50-7/783 a 784

${ }^{77}$ EDELMAN, Bernard. Op. cit., p.187.
} 
deveria, assim, buscar a identificação - e contestação - de seus limites, revelando as contradições existentes nesta ciência.

Dito de outro modo, a própria ideologia do Estado leva este a só pensar como político o que participa do seu próprio funcionamento e a declarar como a-político o que não toma parte nele. Esse 'apolitismo' que, se fosse confessado como político poria o Estado em questão (assim, a greve política é ilegal), é própria garantia de uma ordem que se quer impessoal. (...) A distinção entre direitos políticos e direitos privados funda-se pois, em última instância, sobre a distinção entre aparelho de Estado e sociedade 'privada', a qual é - ela mesma - o lugar da luta ideológica. ${ }^{78}$

Desta maneira, Edelman sustenta que inexistem diferenças a justificar a separação entre greves profissionais, econômicas ou políticas, já que "não podemos saber em nome de quê e como é que poderíamos distinguir os direitos políticos dos direitos sociais (privados)",79.

Para Edelman, “o Direito pode, assim, em nome do próprio Direito, entregar-se à instância política" ${ }^{\prime 0}$, uma vez que não há uma verdadeira distinção entre o âmbito trabalhista e o político/econômico, pois toda atuação que vise melhorar as condições de trabalho também é um reivindicação política - e com reflexos na economia - assim como reivindicações políticas terão estreita ligação com a melhora da condição de vida dos trabalhadores.

\section{2 - Interpretações doutrinárias}

Assim como ocorre com todos os demais direitos, existem diversas concepções doutrinárias quando se trata da greve política. Aqui, metodologicamente, dividir-se-á em apenas duas categorias: a da teoria restritiva e da teoria ampliativa. A primeira engloba os argumentos que veem a greve política como instrumento vedado em nosso ordenamento

\footnotetext{
${ }^{78}$ EDELMAN, Bernard. Op. cit., p.191.

${ }^{79}$ Ibidem, p. 185.

${ }^{80}$ Ibidem, p. 185.
} 
jurídico, enquanto a segunda abarca a linha de pensamento que a concebe como instituto legal.

Não se pretende, neste primeiro momento, expor qualquer tipo de julgamento sobre ambas as teorias, pois esta valoração será realizada em momento oportuno. Esta diferenciação é feita como maneira de demonstrar que, apesar da doutrina majoritária ser partidária da teoria restritiva, a discussão está longe de obter um consenso.

\subsection{1- Teoria Restritiva}

A teoria restritiva pode ser caracterizada de forma simples como aquela que não reconhece a licitude das greves políticas. Esta é a visão dominante na doutrina e na jurisprudência. Para seus adeptos, diversos argumentos levam a crer que a greve política é algo inaceitável.

Inicialmente, aduzem que o empresário não pode injustamente suportar os prejuízos decorrentes de um conflito o qual ele próprio não ocasionou e do qual ele não pode e nem tem condições de gerar uma solução, uma vez que as pretensões da greve não fazem parte de sua esfera de disponibilidade. Ela é, portanto, desproporcionalmente nociva ao empregador, pois estará privado de mão de obra sem que possa resolver o conflito existente. Trata-se de uma questão de sujeito e objeto, pois quem sofre a penalização não é aquele diretamente apto a resolver as exigências dela decorrentes.

Assim, Segadas Vianna defende a ilicitude deste tipo de greve afirmando que lhe falta a "finalidade de reivindicação que possa ser atendida pelo empregador, pois seus objetivos visam a governos e autoridades, visam a instituições"81.

Outro argumento apresentado é quanto à legalidade democrática da greve política. Tal contestação defende que os destinatários da greve política são os representantes diretos da soberania popular, democraticamente escolhidos. Desta maneira, a greve política se apresenta como uma forma de pressão ilícita na formação de vontade de órgãos soberanos.

Defende-se, neste caso, que os problemas políticos em um regime democrático devem ser solucionados por meio de eleições dos representantes do povo ou reforma básica, sempre através do voto da nação inteira, e não apenas pela vontade de alguns trabalhadores. Com isto, afirma-se que a redação do artigo $9^{\circ}$ da Constituição Federal, ao

\footnotetext{
${ }^{81}$ SÜSSEKIND, Arnaldo; MARANHÃO, Délio; VIANNA, Segadas. Instituições de Direito do Trabalho. Rio de
} Janeiro: Freitas Bastos, 1984, V.2. p.1110. 
dispor dos interesses que podem ser defendidos pela greve abarcou apenas os interesses trabalhistas.

Orlando Costa afirma que "sempre que uma paralisação distorcer a finalidade implícita da greve está agredindo o próprio direito, pois estará sendo utilizada com intuito distinto daquele para o qual foi criada". Conclui o autor que é esta a razão pela qual o direito comparado não admite "as greves políticas, dirigidas contra o poder público como poder público e não como empregador" ${ }^{, 2}$.

Na mesma linha de raciocínio pode-se citar Octávio Bueno Magano, que defende a existência de um "condicionamento implícito" no que tange a natureza da greve. Assim, por estar inserida no capítulo que trata da melhoria da condição social do trabalhador, conclui-se que a greve política é ilícita. Conclui que o artigo $9^{\circ} \mathrm{da}$ Constituição Federal, ao dispor que cabe "aos trabalhadores decidir sobre os interesses a serem defendidos por meio da greve, só pode estar se referindo aos que visem à melhoria de condições de trabalho, o que exclui - repita-se - a possibilidade de greves políticas" ${ }^{\text {}} 83$.

Um terceiro ponto que é apresentado pelos defensores da teoria restritiva é o de que o caput do artigo $3^{\circ}$ da Lei 7.783/89, ao dispor que a cessação coletiva do trabalho é facultada uma vez "frustrada a negociação ou verificada a impossibilidade de recursos via arbitral”, condiciona o direito de greve à prévia tentativa de negociação.

Considerando-se que não é possível a negociação coletiva de causas políticas com o empregador, uma vez que estas são pleiteadas contra o Estado, bem como não pode o Estado ser parte de uma negociação coletiva, a deflagração da greve política fica juridicamente impossibilitada.

Para finalizar, não se pode ignorar o argumento apresentado por muitos autores que afirmam que o sindicato é órgão de representação profissional, e não político, cargo este incumbido aos partidos. $\mathrm{O}$ sindicato deve, portanto, manter sua pauta no âmbito estritamente profissional e trabalhista. Tendo isto em vista, não é legítima uma reivindicação sindical que tenha cunho de natureza política, justamente por extrapolar sua esfera de atuação constitucionalmente delimitada.

\footnotetext{
${ }^{82}$ Costa, Orlando Teixeira da. Direito Coletivo do Trabalho e crise econômica. São Paulo: LTr, 1991. p.190.

${ }^{83}$ MAGANO, Octávio Bueno. Greve. In Revista LTr ago/92. São Paulo: LTr, 1992. p.56-08/911
} 
Embora os defensores da teoria restritiva apontem outros raciocínios além dos apresentados, tais argumentos invariavelmente convergem para os quatro pontos acima citados, que podem ser considerados os mais importantes e que balizam todas as refutações à possibilidade legal de uma greve política.

\subsection{2- Teoria Ampliativa}

A teoria ampliativa é defendida por uma parte minoritária dos doutrinadores, entre os quais podemos citar Jorge Luiz Souto Maior, Marcus Orione Gonçalves Correia e Roberto A. O. Santos. Os defensores desta teoria afirmam que o fato de uma greve ser deflagrada com base em uma reivindicação de cunho político não pode servir de motivação para caracterizar sua ilegalidade ou abusividade.

O argumento-base desta teoria é que não há qualquer limitação legal à greve política. Ao contrário, o artigo $9^{\circ}$ da Carta Magna dispõe que compete aos trabalhadores decidir sobre a oportunidade de exercer o direito à greve e sobre os interesses que devam por meio dela defender. Desta maneira, não há vedação legal para uma greve que defenda interesses políticos; se assim o fosse, não teria o legislador estabelecido com tanta amplitude a possibilidade de escolha das finalidades de uma greve. Se fosse intenção do legislador vetar as greves de cunho político, esta proibição estaria expressa no próprio texto legal, tal como ocorria com a Lei 4.330/64.

Como aponta José Afonso, a oportunidade de exercício da greve e os interesses por meio dela defendidos não podem ser restringidos, eis que tais decisões competem unicamente aos trabalhadores. Assim sustenta que "os trabalhadores podem decretar greves reivindicatórias, objetivando a melhoria das condições de trabalho, greves de solidariedade, em apoio a outras empresas, outras categorias ou grupos reprimidos, greves políticas, com o fim de conseguir as transformações econômico-sociais que a sociedade requeria, ou as greves de protesto" ${ }^{84}$.

Neste mesmo sentido se encontra a opinião do Ministro do STF Eros Grau, que defendeu em um de seus votos que "a Constituição, tratando dos trabalhadores em geral, não prevê regulamentação do direito de greve: a eles compete decidir sobre a oportunidade de exercê-lo e sobre os interesses que devam por meio dela defender. Por isso a lei não pode restringi-lo, senão protegê-lo, sendo constitucionalmente admissíveis todos os tipos

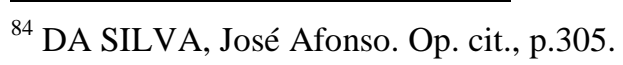


de greve: greves reivindicatórias, greves de solidariedade, greves políticas, greves de protesto" $" 85$.

Outro argumento fundamental é aquele que busca a finalidade última da greve, que é a busca por melhores condições sociais. A greve é uma forma constitucionalmente válida de manifestação dos trabalhadores, e uma de suas funções primordiais é permitir a busca pelos obreiros de uma igualdade formal na sociedade. Desta maneira, esta busca de igualdade não pode ficar restrita a existência de elementos econômico-trabalhistas.

Além disto, é patente a insuficiência das instituições políticas tradicionais para a concretização da igualdade formal entre os cidadãos. Tendo em vista que a classe dominante possui meios legais para influenciar o processo político, negar a atuação dos trabalhadores seria reconhecer que o jogo democrático está favorecendo esta classe dominante. Os sindicatos, por meio de greves, serviriam como contraponto a eventuais arbitrariedades governamentais, que atualmente possuem escassos meios de controle.

Por último, reconhece-se que o estado não é neutro diante dos conflitos econômicos. Não corresponde à realidade e à atual configuração de poderes a separação nítida entre economia e política ou entre Estado e Sociedade Civil. O Estado deixou de ser apenas um elemento de organização política da sociedade capitalista, tornando-se também um elemento atuante deste modelo de organização econômica.

\section{3 - A licitude da greve política}

" Il y a une tristesse ouvrière qu'on ne guérit que par la participation politique." Georges Navel, Travaux, 1945

Expostas as considerações pertinentes ao assunto, faz-se necessária a análise da legalidade da greve política em nosso ordenamento jurídico.

Apesar de ser inerente ao direito uma variada gama de interpretações para os mais diversos textos legais, é curioso constatar que em certos pontos há um consenso da doutrina e da jurisprudência que acabam diminuindo a discussão. Não necessariamente isto é ruim, como em casos de garantias de direitos fundamentais e de conquistas de

\footnotetext{
${ }^{85}$ Voto do Ministro Eros Grau no Mandado de Injunção 712-8 Pará.
} 
civilização. Mas este consenso é preocupante quando ele vai contra a legislação pátria, tanto constitucional quanto infraconstitucional, contra os princípios gerais do Direito Social e até mesmo contra as premissas fundantes do nosso estado democrático de direito.

Como bem observa Roberto A. O. Santos, o ponto de vista contrário à greve política, justamente por ser "repetido por especialistas de tanta credibilidade, acaba por encontrar livre trânsito, deixando em posição desconfortável os que duvidam, logo apontados como 'dissidentes', 'sinais de contradição', etc.”,86

O que se pretende, portanto, é questionar os raciocínios que levam a maioria da doutrina e da jurisprudência brasileira a deduzir que toda greve com motivação política é ilegal e verificar se, efetivamente, há algum obstáculo legal que a impeça.

Como base para este questionamento é necessário verificar o apontamento de Carlos López Monis:

As posições que justificam a ilicitude da greve política se baseiam em duas linhas de argumentos muito nítidas, segundo considerem os destinatários da greve e os interesses perseguidos pela mesma:

a) destaca-se, em primeiro lugar, a não coincidência entre os destinatários da greve e os sujeitos passivos da mesma, o que resulta numa incoerência ao fazer os empresários suportarem as consequências de uma greve quando as pretensões solicitadas não fazem parte da sua esfera de disponibilidade. Nesta mesma linha de consideração sobre os destinatários da greve política, adverte-se que estes são precisamente os representantes da soberania popular, isto é, o Parlamento diretamente e o Governo indiretamente. A greve política constitui, neste sentido, uma pressão na formação da vontade dos órgãos soberanos e, por isso, ilícita; e

b) a segunda linha de argumentação atende ao interesse perseguido pela greve política. A partir de uma série de distinções qualitativas entre 'interesse profissional' e 'interesse político', 'trabalhador', 'cidadão', 'economia' e 'política', se mantém o sindicato no âmbito do estritamente profissional e trabalhista, atribuindo, com exclusividade, ao partido político a capacidade de atuar na esfera da política. $^{87}$

\footnotetext{
${ }^{86}$ SANTOS, Roberto A.O. Uma contribuição sociológica à renovação da teoria jurídica da greve Op. Cit.. p.120.

${ }^{87}$ MonIS, Carlos López. O Direito de Greve: experiências internacionais e doutrina da OIT. São Paulo: LTR, 1986, pág. 36.
} 
O primeiro argumento, e que é tido como basilar pelos defensores desta suposta ilicitude, é o de que o empresário não pode injustamente suportar os prejuízos decorrentes de um conflito do qual ele próprio não ocasionou e do qual ele não pode nem tem condições de gerar uma solução.

Inicialmente, pode-se questionar a veracidade deste argumento. Mesmo através de uma análise superficial percebe-se que não corresponde à realidade e à atual configuração de poderes a separação nítida entre economia e política ou entre Estado e Sociedade Civil; a influência empresarial nas mudanças das políticas governamentais é algo cotidiano, e é facilmente percebida através dos lobbys empresariais ${ }^{88}$ ou das concentrações de grupos de interesses econômicos nas diversas instâncias do poder, como é o caso, por exemplo, da "bancada ruralista" e da "bancada industrial".

O próprio apoio de empresas à campanha eleitoral de determinados candidatos reflete esta participação da economia na política. O objetivo primordial de uma sociedade empresarial é gerar lucro; não há dispêndio de gastos ou doação de valores sem que a eles se vincule algum tipo de retorno financeiro à sociedade. Assim, todo investimento realizado pretende uma margem de retorno proporcional ao valor investido e ao risco da transação. Consequentemente, toda "doação" de valores a campanhas eleitorais nada mais é que um investimento da empresa, que busca influenciar o jogo democrático para sustentar suas posições políticas ${ }^{89}$.

\footnotetext{
${ }^{88}$ Segundo definição de Luigi Graziano "o lobby é a representação política de interesses em nome e em benefício de clientes identificáveis por intermédio de uma panóplia de esquemas que, em princípio, excluem a troca desonesta de favores." (Revista Brasileira de Ciências Sociais; volume 12, número 35. Outubro 1997.) A regulamentação da atividade lobista está sendo debatida desde 2007 no congresso nacional por meio do projeto de lei $\mathrm{n}^{\circ} 1.202$ de 2007. Segundo o artigo $2^{\circ}$ deste projeto de lei, considera-se: "VI - "lobby" ou pressão, o esforço deliberado para influenciar a decisão administrativa ou legislativa em determinado sentido, favorável à entidade representativa de grupo de interesse, ou de alguém atuando em defesa de interesse próprio ou de terceiros, ou em sentido contrário ao interesse de terceiros; VII - lobista ou agente de grupo de interesse, o indivíduo, profissional liberal ou não, a empresa, a associação ou entidade não governamental de qualquer natureza que atue por meio de pressão dirigida a agente público, seu cônjuge ou companheiro ou sobre qualquer de seus parentes, colaterais ou afins até o segundo grau, com o objetivo de lograr a tomada de decisão administrativa ou legislativa favorável ao grupo de interesse que representa, ou contrária ao interesse de terceiros, quando conveniente ao grupo de interesse que representa". A proximidade existente entre o tráfico de influência e o lobby ressalta a importância de um tratamento jurídico específico para esta matéria. Uma fonte interessante para entender melhor o trabalho desempenhado por um lobista é o filme "Obrigado por fumar", de Jason Reitman.

${ }^{89}$ Os enormes montantes financeiros doados por grandes empresas são notórios. A título exemplificativo, podemos citar a doação de $\mathrm{R} \$ 1.640 .000,00$ feita por Votorantim Industrial, a doação de $\mathrm{R} \$ 8.000 .000,00$ por JBS SA e os R $\$ 3.650 .000,00$ doados por Cosan SA Indústria e Comércio à campanha presidencial de Dilma Roussef em 2010. Estes dados estão disponíveis em:
}

< http://spce2010.tse.jus.br/spceweb.consulta.prestacaoconta2010/comiteServlet.do>. Acesso em 28/11/2012. 
Obviamente nem todas as empresas tem tamanha capacidade de pressão, variando de acordo com a estrutura da empresa de que se trata. Contudo, é inegável a grande influência de grandes indústrias e setores nos rumos da política de nosso país. Assim, se a influência do empregador no âmbito político é tão evidente e juridicamente aceita, então porque negá-la quando se trata de permitir aos trabalhadores a ação política por meio da greve? ${ }^{90}$

Assim, através da ideia de equilíbrio democrático das forças que influenciam as esferas de poder, verifica-se que não só o empregador tem diversos meios de influência política como efetivamente os utiliza. Na maior parte dos casos, a greve com objetivo político exercerá a favor dos trabalhadores uma pressão diametralmente oposta àquela realizada pelo empregador através de seus lobistas ou sua influência política.

Ainda que a paragem obreira não represente um contraponto às intenções empresariais e consequentemente não se imponha como divergência de interesses, sua função não perde relevância. Ao contrário, nestes casos, além de exercer pressão imediata à esfera política à qual se dirige, um movimento grevista também pode influenciar a empresa a agir politicamente em prol das reivindicações dos trabalhadores.

Por fim, verifica-se que este argumento de ilegalidade da greve decorre de uma interpretação sem qualquer base legal, eis que apoiada em argumentos externos não apenas ao Direito do Trabalho, mas a todo o Direito como ciência. Trata-se de argumentos de âmbito econômico e administrativo. Uma vez que estamos aqui tratando de um estudo jurídico da greve, estudo este caracterizado pela análise científica, tal argumento que refuta a greve política aparece como algo alheio ao Direito, pois não há lei alguma que o sustente.

Não se defende aqui uma separação hermética do direito, baseado em uma visão positivista decorrente da teoria pura Kelseniana, mas sim uma visão do Direito como ciência social que se inter-relaciona com outras esferas do conhecimento e que mantém seu

\footnotetext{
${ }^{90}$ Neste ponto, a lógica proibitiva deveria ser a oposta. A participação política deveria ser negada às pessoas jurídicas. A participação política democrática parte do pressuposto moral de bem comum. Contudo, o único pressuposto que possuem as pessoas jurídicas é a maximização do lucro, ainda que para sua efetivação atentem contra o bem comum. Cármen Lúcia, ministra do Supremo Tribunal Federal e atual presidente do Tribunal Superior Eleitoral, defendeu em entrevista recente a proibição de doações provenientes de pessoas jurícias a campanhas políticas. Segundo a ministra: "De toda sorte, este é um assunto que precisa ser devidamente esclarecido. Por exemplo, pessoa jurídica não é cidadão e não vota. Não há por que empresa fazer financiamento de campanhas. Esse é um dado que precisa mesmo de ficar às claras. Pessoa jurídica não deveria contribuir, porque não é cidadão." Istoé Dinheiro, "TSE defende fim de doações de empresas". Disponível em:
}

<www.istoedinheiro.com.br/noticias/105255_TSE+DEFENDE+FIM+DE+DOACOES+DE+EMPRESAS> . Acesso em 25/11/2012. 
caráter de campo de estudo com regras, princípios e valores próprios. Não se pode admitir, portanto, argumentos de outras áreas de estudo como se fossem jurídicos e pretender que, através de um exercício de sopesamento, estes neguem garantias legais e afrontem princípios próprios do Direito Social, sob pena de negá-lo como ciência e fragilizar importantes conquistas de humanidade. Como aponta Jorge Luiz Souto Maior:

\footnotetext{
O ordenamento jurídico trabalhista foi criado sob a ótica da ordem pública exatamente para que os arranjos econômicos, que naturalmente são bastante maleáveis, não pudessem criar embaraços à sua efetividade. Esta enunciação de princípio, que reserva à jurisprudência um grande papel normatizador (vide, a propósito, o art. $8^{\circ}$, da CLT), está em todos os escritos que forneceram a base da formação do Direito do Trabalho.

Assim, o que cabe ao Direito do Trabalho é proporcionar instrumentos para a reconstrução da relação entre o capital e o trabalho, pois o Direito do Trabalho, para ser eficaz, depende - e só tem sentido nesse contexto -, logicamente, do capital que o sustenta. ${ }^{91}$
}

Ressalte-se que este poder normatizador conferido às decisões judiciais trabalhistas só tem sentido dentro da lógica de proteção própria do Direito do Trabalho. Não pode a jurisprudência trabalhista, sob o argumento de limitações econômicas do mercado de capitais, negar efetividade às normas que regem as relações de trabalho e aos princípios do Direito Social. O Direito do Trabalho não pode ser utilizado como instrumento para sua própria negação. O julgador deve utilizar o ordenamento jurídico para extrair os fundamentos que sustentarão seus julgamentos, de modo a promover e efetivar os direitos trabalhistas.

Evidente que a realidade social influencia o direito, assim como o direito influencia a realidade social. Contudo, esta influência deve ocorrer sempre para garantir mais direitos e reafirmar a dignidade humana. Argumentos de ordem econômica que têm como único objetivo restringir direitos sociais não podem ser aceitos como influência possível na ciência do direito.

Em termos jurídicos, sobretudo na perspectiva do Direito Social, não tem sentido a mera verificação dos fatos. A função do direito e principalmente do Direito

${ }^{91}$ MAIOR, JORGE LUIZ SOUTO. Op. cit., p.138 
Social não é senão a de corrigir a realidade, atribuir efeitos obrigacionais necessários às relações sociais, para fazer valer os valores que nele foram integrados por obra da humanidade. E, o dever ser jurídico é uma prescrição que gera, por óbvio, obrigações na vida real. ${ }^{92}$

Outro argumento utilizado pelos defensores da teoria restritiva é a da impossibilidade da greve com finalidade política por representar uma afronta à democracia, uma vez que esta exerceria uma pressão ilícita na formação de vontade dos poderes da república e que estes devem agir livremente por serem representantes diretos da soberania popular, democraticamente escolhidos.

Como visto anteriormente, a pressão na formação de vontade das esferas governamentais de maneira alguma constitui em si um delito. Ao contrário, para que esta formação de vontade seja democraticamente representativa deve contar com a pressão dos diversos setores da sociedade. O mero fato de serem eleitos por meio do voto secreto não dá aos representantes do povo o poder-dever de agir livremente.

A participação política na atual concepção de democracia expande-se para além dos conceitos da democracia formal. A ideia clássica da democracia formal, onde o âmbito de atuação do indivíduo na política se realiza unicamente como cidadão e através do voto periódico para a escolha dos representantes do povo encontra-se superada.

Esta superação na democracia contemporânea trata-se de posição majoritária, que ultrapassa diversas correntes de pensamento. Como aponta Amartya Sen, "na filosofia política contemporânea a ideia de que a democracia é mais bem vista como 'governo por meio do debate' ganhou ampla aceitação",93.

A democracia contemporânea é o resultado da participação dos indivíduos na esfera política, não apenas através de políticos eleitos, mas também através de reivindicações, protestos, exigências, abaixo-assinados, entre outros atos que visem manifestar a vontade popular e atuar politicamente.

\footnotetext{
${ }^{92}$ Ibidem, p.138.

${ }^{93}$ SEN, Amartya. A ideia de justiça. São Paulo: Companhia das Letras, 2011. P.358. O autor aponta ainda à página 360: "Há evidentemente muitas diferenças entre os distintos modos nos quais o papel da argumentação pública na política e na ética discursiva pode ser visto. (...) O mais importante é observar que a totalidade dessas novas contribuições ajudou a trazer o reconhecimento geral de que os pontos centrais de uma compreensão mais ampla da democracia são a participação política, o diálogo e a interação pública”.
} 
No atual momento histórico de complexas e atomizadas relações sociais, restringir a participação democrática ao simples ato de votar seria limitar a própria democracia. O ser humano deve ser compreendido dentro de sua complexidade e dos sentidos que são impressos pelo papel que desempenha na sociedade. Somente através desta compreensão será possível efetivar a democracia através de espaços mais amplos de formação de poder. Como aponta Bobbio em O futuro da democracia:

\begin{abstract}
O que acontece agora é que o processo de democratização, ou seja, o processo de expansão do poder ascendente, está se estendendo da esfera das relações políticas, das relações nas quais o indivíduo é considerado em seu papel de cidadão, para a esfera das relações sociais, onde o indivíduo é considerado na variedade de seus status e de seus papéis específicos, por exemplo de pai e de filho, de cônjuge, de empresário e de trabalhador, de professor e de estudante e até mesmo de pai de estudante, de médico e de doente, de oficial e de soldado, de administrador e de administrado, de produtor e de consumidor, de gestor de serviços públicos e de usuário, etc.

Com uma expressão sintética pode-se dizer que, se hoje se pode falar de processo de democratização, ele consiste não tanto, como erroneamente muitas vezes se diz, na passagem da democracia representativa para a democracia direta quanto da passagem da democracia política em sentido estrito para a democracia social, ou melhor, consiste na extensão do poder ascendente, que até agora havia ocupado quase exclusivamente o campo da grande sociedade política (e das pequenas, minúsculas, em geral politicamente irrelevantes associações voluntárias), para o campo da sociedade civil nas suas várias articulações, da escola à fábrica. ${ }^{94}$
\end{abstract}

Dentro deste contexto, a noção de "trabalhador" surge como a representação do individuo dentro da unidade de prática social decorrente do contexto estrutural do trabalho ${ }^{95}$. O trabalhador surge como o ser social pertencente à "classe que vive do trabalho", mas sem se desvincular materialmente do contexto estrutural da cidadania. No atual estágio da democracia, não há que se falar em qualquer separação do individuo

\footnotetext{
${ }^{94}$ BobBIO, Norberto. O futuro da Democracia. 10a edição. São Paulo: Paz e Terra, 2006. P.67

95 O quadro proposto por Boaventura de Souza Santos à página 153 em seu livro "Introdução a uma ciência pós-moderna", $4^{\mathrm{a}}$ edição, Ed. Graal, 2003, expõe sua interpretação dos contextos estruturais do capitalismo, lembrando o autor que tais contextos "apesar de estruturalmente autônomos no plano teórico, estão articulados entre si e interpenetram-se de múltiplas formas"(pag.152).
} 
enquanto trabalhador ou enquanto cidadão membro da sociedade civil. Conforme Souto Maior:

(...) em uma democracia deve-se abarcar a possibilidade concreta de que os membros da sociedade, nos seus diversos segmentos, possam se organizar para serem ouvidos. A greve, sendo modo de expressão dos trabalhadores, é um mecanismo necessário para que a democracia atinja às relações de trabalho. ${ }^{96}$

Esclarecida a possibilidade de atuação dos trabalhadores na esfera política, é evidente que a forma mais eficaz de realiza-la é com o direito responsável pela maioria das conquistas políticas dos trabalhadores: o direito de greve.

A coletividade de trabalhadores, ao deflagrar um movimento grevista, possui legitimidade na esfera política para a concretização de seus pleitos. A admissão do exercício de uma greve com fins políticos é um exemplo de efetivação da democracia em um Estado de Direito. Sendo a greve uma forma legítima dos trabalhadores expressarem suas reivindicações, exercerem pressão para que estas sejam atendidas e manifestarem insatisfações, a greve política nada mais é que a ampliação deste exercício para além da relação patrão-empregado. Como aponta Dockès:

E são notadamente alguns direitos fundamentais que permitem aos cidadãos de contestar as decisões do poder e a elas se opor: direito de expressão, direito de petição, direito de manifestação e também direito de greve. A efetividade de uma democracia se julga pelos direitos reconhecidos aos opositores. Proibir as greves dirigidas contra os eleito em nome da idéia de democracia é um grande contra-senso com a idéia de "democracia". ${ }^{97}$

\footnotetext{
${ }^{96}$ MAIOR, Jorge Luiz Souto. Greve e Salário. Disponível em <www.migalhas.com.br/dePeso/16,MI109693,81042-Greve+e+salario >. Acesso em 05/12/2012
}

${ }^{97}$ DOCKÈS, Emmanuel. La finalité des grèves en question. Droit Social, 2006, n॰ 9/10, p. 883. 
O próprio surgimento e desenvolvimento do Direito do Trabalho tem estreita relação com os movimentos grevistas perpetrados pelo operariado nos últimos dois séculos. Muitas conquistas sociais e políticas fundamentais somente foram conquistadas com o suporte de movimentos grevistas. Hoje, ao analisar estes movimentos grevistas, é pacífico o entendimento de que eles foram essenciais para uma evolução do Estado democrático e da legislação social. Temos como exemplo as greves na França e na Inglaterra no século XIX, responsáveis pela redução da jornada de trabalho e por consagrar outros importantes direitos trabalhistas. Também podemos citar as greves do final da década de 1970 na região do $\mathrm{ABC}$ paulista, importantes marcos no processo de redemocratização do Brasil, mas que na época de sua deflagração foram duramente reprimidas. Até mesmo o dia $1^{\circ}$ de maio, dia mundial de lutda dos trabalhadores, é uma data escolhida em decorrência de opressões sofridas pelos trabalhadores em movimentos grevistas, como o ocorrido em 1886 nos Estados Unidos e que foi brutalmente reprimido.

Embora reverenciem a importância das greves políticas do passado, ao analisar as greves políticas atuais a doutrina majoritária contraditoriamente defende que estas exercem pressões ilícitas nos órgãos do poder. Por certo as greves do passado sofreram as mesmas acusações que sofrem as atuais, havendo além de uma falha do próprio conceito de democracia neste argumento, uma patente negação histórica da greve. Observa-se a importância e os benefícios obtidos com as greves no passado, mas nega-se esta possibilidade às greves do presente.

Dentre evidentes contradições, é interessante observar que até mesmo a OIT, apesar de ter manifestado em um de seus relatórios que as greves políticas "não se enquadram no âmbito dos princípios da liberdade sindical"98, afirmou em outro relatório que este tipo de protesto se tornou "ponta-de-lança da democracia da África", pois "os sindicatos se converteram em um elemento de coordenação para a mudança política. Suas pressões e reivindicações têm acelerado a democratização em muitos países"99.

Negar a possibilidade política à greve acarreta o grave erro de desconsiderar toda a historicidade presente na democracia e vislumbra-la como uma estrutura única e completa. Evidente que o Estado Democrático de Direito está em constante aperfeiçoamento através dos diversos conflitos existentes na sociedade - ainda que algumas

\footnotetext{
${ }^{98}$ Comitê de Liberdade Sindical da OIT, verbete 364

${ }^{99}$ Apud SANTOS, Roberto A.O. Op. Cit. p.128.
} 
vezes estes conflitos sejam apenas para evitar retrocessos nesta evolução de conquistas sociais. A greve política não pode ser vista como um objeto de museu que perdeu sua importância de outrora. Ao contrário, a greve política deve ser vista como importante meio de proporcionar novas conquistas e garantir a evolução da sociedade.

Não se pode admitir aqui um "direito aos vencedores", que só será legitimado futuramente caso o desenrolar histórico demonstre - sempre através do olhar distanciado que só o tempo permite - que a greve foi legítima em decorrência da conjuntura da época, ainda que tenha sido repreendida quando deflagrada. $\mathrm{O}$ direito não pode assumir este caráter temerário. A greve política deve ser reconhecida como um direito dos trabalhadores no presente, e não apenas como movimentos historicamente importantes. A greve não deve ser tratada como um ato heroico, a greve deve ser o exercício regular de um direito constitucionalmente garantido.

Pertinente a observação de Roberto A. O. Santos ao indagar "como decidiram os Tribunais do Trabalho se, rejeitado o pedido de impeachment do Presidente F. Collor pela Câmara, os trabalhadores decretassem greve geral 'pela ética na política'?”,100 101.

Há também a afirmação recorrente proferida pela doutrina conservadora de que a condenação da greve política está em conformidade com a intenção do legislador, uma vez que o conceito de "interesses" dado pela redação do artigo $9^{\circ}$ da Constituição Federal abrange apenas os interesses trabalhistas.

Todavia, para justificar a natureza desta restrição, os diversos autores sempre recorrem ao argumento de uma motivação "implícita", como se a restrição ao âmbito negocial-trabalhista para configuração da legalidade da greve estivesse subentendida na própria norma. Fazem uma leitura restritiva deste direito constitucionalmente garantido. Ao fazer esta leitura equivocam-se tais doutrinadores. Evidente que se trata de uma interpretação constitucional involutiva "em que se cria, por meio do falso exercício hermenêutico, o sentido da demolição de direitos que a própria Constituição vinha conflagrando e prestigiando"102.

\footnotetext{
${ }^{100}$ Ibidem, p. 128.

${ }^{101}$ Complemento esta observação questionando: caso tal greve fosse deflagrada e o impeachment ocorresse graças à sua pressão, ainda que à época fosse proferida decisão declarando a greve ilegal por ser política, como a doutrina analisaria sua importância hoje? Não seria exagero dizer que seria vista como ato heróico em benefício da democracia.

${ }^{102}$ CORREIA, Marcus O.G. Direito Constitucional do Trabalho - Relações coletivas, in Correia, Marcus O.G.(org), Curso de Direito do Trabalho. São Paulo: LTr, 2007, vol. I, p. 29.
} 
Assim como ocorre com os demais direitos fundamentais, o direito de greve deve ser analisado com o objetivo de garantir a eficácia e estender a aplicação destes direitos, ampliando-se as possibilidades de execução. Como reconhecido até mesmo em um acórdão do Tribunal Regional do Trabalho de São Paulo, os direitos fundamentais se revestem de força expansiva, "alcançando todas as demais situações não expressamente vedadas pelo ordenamento" ${ }^{103}$. Uma leitura que recorre à motivação implícita para apontar a ilegalidade da greve política flagrantemente não respeita nenhum dos sentidos interpretativos da lei de greve ou da Constituição Federal, seja ele gramatical, axiológico, teleológico ou sistêmico.

Nem se diga tampouco que esta restrição está de acordo com a vontade do legislador. A Constituição de 1988 foi profícua em sua abordagem social, o que lhe gerou inclusive a alcunha de "constituição cidadã". Diversos entraves político-sociais marcaram as questões mais polêmicas, e não o foi diferente com o direito de greve.

Segundo matéria publicada no jornal Folha de São Paulo em 11 de setembro de $1988^{104}$, após 19 meses de intensos debates no Congresso constituinte, entre outros pontos foi aprovado o direito irrestrito de greve. Tais informações, obtidas à época dos fatos através do Centro de Informática e Processamento de Dados do Senado Federal (Prodasen), demonstram a amplitude pretendida pelo legislador em relação ao direito de greve. Consta na parte de "História das votações" desta matéria jornalística:

Direito Irrestrito de greve - Aprovado no primeiro turno de votações da Constituinte, o direito irrestrito de greve foi atacado por vários parlamentares, que apresentaram emendas para restringi-lo. Foram derrotados, como se pode ver ao lado.

Como esclarece, em votação constituinte foi aprovado o direito irrestrito de greve. As emendas restritivas, o que eventualmente incluía a restrição à greve com

\footnotetext{
${ }^{103}$ Processo TRT/SP $00014788720105020074-$ RO. Rel. Susete Mendes Barboza de Azevedo.

${ }^{104}$ Lopes, Mauro. Constituinte racha os partidos de centro; esquerda fica unida. In Folha de São Paulo, 11 de setembro de 1988, Primeiro Caderno, páginas A10 e A12. Disponível em

$<$ http://acervo.folha.com.br/fsp/1988/09/11/2/>. Acesso em 16/11/2012.
} 
finalidade política, foram rejeitadas pela maioria. Em 16 de agosto de 1988, ao ser levado à votação, a aprovação do direito irrestrito de greve foi aprovado por esmagadora maioria ${ }^{105}$ :

\begin{tabular}{|c|c|c|c|}
\hline \multicolumn{5}{|c|}{$\begin{array}{c}\text { Direito irrestrito de greve } \\
(16 / 08 / 88)\end{array}$} \\
\hline Partido & Sim & Não & Abs \\
\hline PC do B & 5 & - & - \\
\hline PCB & 3 & - & - \\
\hline PDC & 1 & 1 & 1 \\
\hline PDS & 10 & 17 & - \\
\hline PDT & 22 & - & - \\
\hline PFL & 30 & 61 & 2 \\
\hline PL & 5 & 1 & - \\
\hline PMB & 1 & - & - \\
\hline PMDB & 133 & 29 & 5 \\
\hline PSB & 5 & - & - \\
\hline PSDB & 43 & - & - \\
\hline PT & 16 & - & - \\
\hline PTB & 10 & 3 & - \\
\hline PTR & 1 & - & - \\
\hline S / P & 3 & - & - \\
\hline Total & 288 & 112 & 8 \\
\hline
\end{tabular}

Desta maneira, impossível sustentar que a limitação da greve política é implícita, decorrente do texto constitucional ou da vontade do legislador constituinte. Qualquer limitação deste tipo deveria ser matéria de aprovação legislativa, o que não ocorreu. Válido o texto constitucional nos exatos termos que conhecemos, que não limita em momento algum a greve em decorrência de sua finalidade mas, ao contrário, estabelece seu caráter irrestrito.

Há também quem defenda que a impossibilidade da greve política encontra respaldo em impedimentos formais, uma vez que a Lei 7.783/89 condiciona a deflagração da greve à prévia tentativa de negociação. Afirma-se que, por não poder o Estado ser parte de uma negociação coletiva, resta prejudicada a negociação coletiva de causas políticas e, consequentemente, toda esta modalidade grevista.

\footnotetext{
${ }^{105}$ Interessante também a tabela "O voto doa 40 parlamentares que mais se destacaram", publicada à página A12 do jornal supracitado, na qual o repórter publica como votaram alguns dos constituintes, inclusive em relação ao direito irrestrito de greve. Apenas a título de curiosidade, Fernando Henrique Cardoso, Mario Covas, Nelson Jobim e Luis Inácio Lula da Silva votaram favoravelmente à greve como direito irrestrito.
} 
O Estado, argumenta-se, não possui meios institucionais de representação para participar de negociações com os trabalhadores. Este ponto é contrário aos mais básicos princípios do direito, já que os trabalhadores são prejudicados pelo não cumprimento de um ônus da outra parte, neste caso o Estado. Contudo, não se trata aqui de fato impeditivo do direito dos trabalhadores.

Não é ônus exclusivo dos trabalhadores garantir a negociação prévia. Estando os trabalhadores à disposição para negociar, o fato da parte adversa, neste caso o Estado, se apartar das negociações não pode de maneira alguma lhe reverter em benefício. Deveria o Estado providenciar meios de assegurar a negociação prévia com os trabalhadores.

Além disto, o artigo $3^{\circ}$ da lei de greve enuncia que é facultada a cessação coletiva do trabalho uma vez "frustrada a negociação ou verificada a impossibilidade de recursos via arbitral". Ora, frustrar a negociação não se resume apenas à impossibilidade de conciliação, mas também à própria impossibilidade de negociação.

Frustado. [Part. De frustrar] Adj. 1. Malogrado, falhado, baldado, frustro. 2. Que não chegou a desenvolver-se; incompleto, imperfeito, frustro. 3. Que não atingiu o seu ideal, a sua ambição, o seu desejo.

Desta maneira, uma vez que o Estado não pode participar das negociações, estas nem chegam a desenvolver-se, restando assim frustrada a negociação coletiva, exigência esta expressa no próprio texto legal. Não há, portanto, qualquer óbice neste ponto.

Como último argumento a ser questionado, resta aquele que afirma que a deflagração de uma greve política por parte de um sindicato representa um desvio das atribuições básicas deste, uma vez que a atuação sindical deve se restringir apenas ao âmbito estritamente profissional e trabalhista. Não seria legítima uma reivindicação sindical que tenha cunho de natureza política, pois constitucionalmente é incumbida aos partidos políticos a representação política dos cidadãos, ocorrendo a invasão de uma esfera de atuação constitucionalmente delimitada.

É interessante notar que este raciocínio não implica na ilegalidade das greves políticas, apenas da atuação sindical. Assim, greves que não fossem deflagradas por sindicatos, mas por comissões independentes de trabalhadores, estariam isentas desta suposta ilicitude. 
Aqui, há que se questionar esta suposta extrapolação da atuação sindical. Primeiramente, a formação de partidos políticos decorre da própria existência de um Estado democrático. Os partidos possuem uma importante função, na medida em que possibilitam variadas perspectivas políticas para que o eleitorado escolha. Contudo, reiterando opinião exposta anteriormente, a democracia não se resume a esta escolha dos representantes do povo. Restringir a esfera de atuação política aos partidos seria invalidar a premissa que os garante, que é a própria democracia.

Não se pode negar a influência política de todos os órgãos e agentes da sociedade; mesmo um sindicato funcionalmente inoperante tem uma atuação política, que é aquela que preza pela manutenção do status quo. Manter as coisas como estão (ou aceitar as mudanças que ocorrem sem contestá-las) é uma escolha política. Atualmente muito se fala da necessidade de aumento da "sociabilidade do sindicato", questionando sua função e efetividade; contudo, na prática se verifica uma grande restrição à sua atuação social.

A aplicação da lei ocorre sempre no caso concreto. Este precisa ser cuidadosamente analisado. Não é legítimo a um Estado de Direito que se pretenda democrático a proibição a priori de um movimento que, muito mais do que não possuir qualquer vedação legal, é assegurado por lei constitucional. 


\title{
4 - O PODER JUDICIÁRIO BRASILEIRO E A GREVE POLÍTICA
}

\author{
“A relação do que é dito e do que está oculto é a própria prática que a designa. \\ (...) \\ Veremos então animarem-se estas categorias, vê-las-emos celebrar contratos de \\ trabalho, vê-las-emos justificar condenações por greve ilícita, vê-las-emos \\ aplicar as regras necessárias das relações de produção. Mais não direi: apenas \\ que tratarei de mostrar o que as anima e não animá-las. O que move as \\ marionettes encontra-se sempre nos bastidores".
}

EDELMAN, Bernard. O direito captado pela fotografia.

Neste capítulo realizaremos a análise de decisões proferidas por nossos tribunais em relação às greves políticas. Procuraremos utilizar os conceitos anteriormente expostos para estudar de forma crítica o pensamento jurídico de nossos julgadores.

Em que pese a vontade de reunir aqui todos os julgados relativos às greves políticas mais importantes, algumas decisões não foram encontradas durante a pesquisa documental. O caso mais emblemático é o das greves de Contagem e Osasco no ano de 1968. Apesar da extrema importância histórica destas greves de cunho político contestador, não logramos encontrar nenhum registro judicial a seu respeito. Igualmente não foi encontrada a decisão judicial relativa à greve dos trabalhadores da Companhia Siderúrgica Nacional realizada em 1988.

Infelizmente o acesso à jurisprudência de nossos tribunais é descentralizado e metodologicamente desorganizado. Importantes decisões não tiveram seu inteiro teor publicado nem foram digitalizadas. Algumas decisões só são disponibilizadas pelo Tribunal prolator através de longo processo burocrático, isso quando são localizadas. Contudo, foi possível reunir importantes julgados sobre a questão da greve política, que demonstram o tratamento jurisprudencial sobre a questão. Parte da contribuição deste trabalho decorre justamente da reunião destes importantes julgados, disponibilizados ao final em anexo de forma acessível a outros pesquisadores. 


\section{1 - As greves no ABC pulista de 1978 a 1980}

"Os operários da Saab-Scania pararam. A notícia chegou ao sindicato na tarde do
dia 12 de maio, causando certa surpresa. Afinal, há mais de dez anos não
acontecia uma paralização desse tipo. Logo, porém, percebia-se não ser o
acontecimento nada de extraordinário: apenas havia chegado a hora dos
trabalhadores, por si mesmos, se livrarem da mordaça que, há vários anos, os
empedia de protestar por suas justas reivindicações. Tinham agora ganhado
consciência de sua força e faziam o primeiro teste numa briga mais séria com os
patrões."

O estudo da conjuntura que possibilitou a construção dos grandes movimentos grevistas que ocorreram no final da década de 70 é objeto de inúmeras obras no campo da história e da sociologia. Contudo, poucas são as obras jurídicas que tratam do assunto e, especificamente em relação à análise das decisões judiciais destas greves, as obras, se existentes, são raríssimas.

Assim, embora estas decisões tenham sido proferidas sob a égide da Constituição de 1969, seu estudo jurídico é de fundamental importância, sobretudo em decorrência dos argumentos e lógicas utilizados pelos magistrados da época. A análise das decisões judiciais das greves de 1978-1980 fortalece a visão da greve como um direito que historicamente representa uma forma de evolução democrática no mundo do trabalho e que deve ser assegurada contra as indevidas tentativas político-econômicas de limitação.

As greves de 1978-1980 não foram as únicas paralisações que ocorreram durante o regime militar. As grandes greves de 1968 ocorridas em Contagem e em Osasco foram importantes movimentos na história trabalhista brasileira. Ocorreram greves também no ACB, como em 1973 e 1974 na Ford, na Massey Fergusson e na Vilares. Tais movimentos foram fundamentais no desenvolvimento da consciência coletiva dos trabalhadores a possibilitar as greves do final da década de 70. Ruy Braga aponta que "na verdade, essas greves (de 1968 em Contagem e Osasco), assim como as paralisações de meados da década de 70 (1973 e 1974 na Ford) prefiguraram em muitos aspectos, a

\footnotetext{
${ }^{106}$ Jornal Tribuna Metalúrgica, nº46, 1978, p.11.
} 
começar pela centralidade política do chão de fábrica, e eclosão do ciclo grevista de 1978$1980^{107}$.

A eclosão das greves de 1978-1980 representa um importante marco no confronto com a ditadura militar brasileira e adquire sua relevância graças à amplitude e força do movimento, às conquistas adquiridas e ao fortalecimento da consciência de classe dos trabalhadores. Ademais, trata-se de greves que possuíam um inegável caráter político, eis que "seja por questões relativas aos salários, seja por conta das duras condições de trabalho, as greves metalúrgicas questionavam diretamente a política econômica da ditadura" $^{108}$.

A primeira greve teve início em 12 de maio de 1978, com a paralisação dos trabalhadores da empresa Saab-Scania. Nos dias seguintes, trabalhadores da Ford, da Volkswagen e Mercedes-Benz aderiram ao movimento grevista e cruzaram os braços. Inspirados por estes movimentos, trabalhadores de diversas outras fábricas também pararam, como na Toshiba, na Massey Fergusson e na Philco.

Deve-se apontar, contudo, que estes movimentos não possuíam uma articulação centralizada. Embora compartilhassem a proximidade geográfica e o momento histórico, as chamadas greves de 1978 não representam um movimento único, mas sim diversas paralisações em diversas empresas. Algumas greves tiveram curta duração, rapidamente firmando acordo com os empregadores. Nem todas as greves foram objeto de dissídio coletivo judicial.

Desta maneira, imperativo esclarecer que a decisão judicial analisada corresponde ao dissídio coletivo instaurado pela Procuradoria Regional do Trabalho da $2^{\text {a }}$ Região em decorrência das paralisações nas fábricas da Saab-Scania, da Mercedes Benz, da Ford e da Karmann Ghia. Segundo a procuradoria, este dissídio coletivo foi movido em decorrência da ilegalidade do movimento grevista e, sobretudo, pela "iminência de ser alargada, abrangendo outras da categoria precitada". Deixa claro a procuradoria que pretende a condenação desta greve como forma de impedir a deflagração de outros movimentos de paralisação.

Trata-se do processo 99/78, no qual foram proferidos dois acórdãos, um pelo Tribunal Regional do Trabalho de São Paulo e outro pelo Tribunal Superior do Trabalho.

\footnotetext{
${ }^{107}$ BRAGA, Ruy. A política do precariado. São Paulo: Boitempo, 2012, p. 161.

${ }^{108}$ BRAGA, Ruy. Op. cit., p. 169.
} 
Ambas as decisões tratam de duas questões centrais: a validade jurídica da Lei 4.330/64 e a legalidade da greve.

O acórdão do TRT/SP, relatado pelo desembargador Nelson Ferreira de Souza, inicia seu voto examinando a constitucionalidade da Lei 4.330/64. A questão é posta em decorrência da alegação de revogação desta lei quando da promulgação da Constituição de 1969. Isto porque a lei de 64 condiciona o direito de greve a tantas condições e fixa inúmeras restrições, o que acaba na prática impedindo o exercício da greve. A Constituição de 1969, por outro lado, assegurou em seu art.165, XXI:

Artigo 165. A Constituição assegura aos trabalhadores os seguintes direitos, além de outros que, nos termos da lei, visem à melhoria de sua condição social: XXI - greve, salvo o disposto no artigo $162^{109}$.

Sustentaram os sindicatos obreiros que a Constituição, ao assegurar este direito aos trabalhadores, revogou a Lei 4.330/64, eis que contrária à norma legal hierarquicamente superior e posterior. Entretanto, o entendimento dos magistrados foi no sentido contrário, apontando a plena aplicabilidade da lei em questão. Segundo o relator do voto:

Portanto, a Lei 4.330, asseguradora do direito de greve, embora, pre-existente à carta magna de 69, data venia de entendimentos contrários, está em pleno vigor, isto porque o texto constitucional se refere expressamente "nos termos da lei", evidentemente, ratificando a lei anteriormente sancionada, pois não é dado ao legislador deixar de considerar o negócio jurídico de tão alta indagação. Sequer contém o texto da lei maior o condicionamento a futura lei ordinária sobre matéria de greve.

Contudo, a simples leitura da norma constitucional é suficiente para refutar este posicionamento. Evidente a expressão "nos termos da lei" se refere à existência de outros direitos além dos elencados neste artigo que também visem à melhoria da condição social dos trabalhadores. Assim, ficam assegurados os direitos expostos no artigo 165 além de outros previstos em legislação infraconstitucional. A única limitação ao direito de greve

${ }^{109}$ Artigo 162. Não será permitida greve nos serviços públicos e atividades essenciais, definidas em lei. 
consta no próprio inciso XXI que, ao remeter a questão ao artigo 162, proíbe a greve nos serviços públicos e atividades essenciais.

Ademais, trata-se de ponto pacífico no Direito que norma posterior revoga norma anterior de igual ou menor nível hierárquico. A constituição de 1969, ao assegurar o exercício do direito de greve, revogou a norma restritiva de direito anterior. Assim, a Lei 4.330/64 estaria revogada.

Contudo, o entendimento do TRT foi mantido pelo TST. Em seu voto o relator Mozart Victor Russomano expôs que:

\begin{abstract}
Se se adotasse o sistema europeu de exegese do texto constitucional, poder-se-ia dizer que a norma que reconhece o direito de greve, enquanto não for regulamentada, pode ser exercida plenamente, sem limites ou restrições. Mas, no Brasil, nosso Direito Constitucional está preso à tradição e à técnica norteamericana: É preciso distinguir entre os dispositivos programáticos e os preceitos self-executing contidos na lei fundamental da República. Ora, os dispositivos do art.165 da Constituição em vigor são programáticos, no self-executing, de modo que, enquanto não sobrevier lei ordinária nova, regulamentando seu inciso XXI, continua desempenhando esse papel regulamentador a Lei. $n^{\circ} 7.330 / 64$, que apenas foi revogada no que atrita com o art.162 da carta.
\end{abstract}

Evidente a atuação política do legislador ao interpretar a aplicação das normas. A opção pela "técnica norte-americana", pela configuração do artigo 165 como "no selfexecuting" e até mesmo pela limitação da revogação ao art.162 são demonstrações das opções políticas do magistrado quando da aplicação da lei. O próprio método de interpretação legal é uma opção política e, dentre todos os casos estudados, este é o que melhor transparece esta questão.

Ante a aplicabilidade da Lei 4.330/64, o voto seguiu com a análise da legalidade do movimento grevista. Em decorrência das condições restritivas impostas por esta lei, a greve foi considerada ilegal, uma vez que não cumpriu com todas as formalidades deliberativas nem cumpriu o prazo de aviso prévio ao empregador. $\mathrm{O}$ Tribunal encerrou a greve no dia 18 de março de 1978, determinando o retorno dos empregados ao serviço no dia seguinte, bem como deixou o pagamento de salário relativo aos dias de paralisação a critério dos empregadores. 
Em seu voto vencido, o magistrado Oswaldo Perez sustentou que, apesar da ilegalidade da greve, não deveria haver punições aos trabalhadores, tal como o corte de salários, eis que:

O movimento paredista, que envolve os trabalhadores da categoria dissidente, nos termos da Lei $n^{\circ} 4.330 / 64$, é efetivamente um movimento ilegal, entretanto, não se pode usar do rigorismo da lei para abranger aqueles obreiros, porque aquele movimento além de pacífico é espontâneo e não constitui um movimento de rebelião contra a autoridade, mas simples desabafo.

Ao analisar o recurso em relação à legalidade da greve, o relator do processo no TST apontou que "a situação política brasileira passou e está passando por uma brusca e louvável metamorfose, no sentido da democratização de suas instituições". Apontou assim a restrição da greve como ato totalitário e contrário aos princípios democráticos. Entretanto, deixou de assegurar este direito aos trabalhadores no caso concreto afirmando que "não importa, entretanto, ao julgador esse aspecto social ou político da greve, porque existem, no caso, leis expressas (...) o Juiz continua preso ao princípio da legalidade". Verifica-se que o julgador esconde sua opção política atrás da aparência de estrito cumprimento do dever legal. Contudo, a própria escolha interpretativa é uma escolha política, como visto acima. Como bem expressa Fábio Konder Comparato:

O Juiz não pode, sob o falso argumento de que não é um órgão político, recusarse a apreciar eticamente as lides submetidas ao seu julgamento. A finalidade ultima do ato de julgar consiste em fazer justiça, não em aplicar cegamente as normas de direito positivo. Ora, a justiça, como advertiu a sabedoria clássica, consiste em dar a cada um o que é seu. O que pertence essencialmente a cada individuo, pela sua própria natureza, é a dignidade de pessoa humana, supremo valor ético. Uma decisão judicial que negue, no caso concreto, a dignidade humana é imoral e, portanto, juridicamente insustentável ${ }^{110}$.

Termina o relator seu voto reconhecendo a importância deste movimento grevista e a legitimidade de suas reivindicações e, como se lavasse as mãos da decisão que

110 Comparato, Fabio Konder. O papel do juiz na efetivação dos direitos humanos, in Direitos humanos: visões contemporâneas. Revista de comemoração dos 100 anos da Associação dos Juízes para a Democracia, São Paulo, 2001. p.17. 
proferira, afirma que "nesse sentido, as greves brasileiras são as dores do parto democrático. São as dores de dilatação, terríveis e violentas, que constituem risco calculado em todas as délivrances".

A prova de como a questão poderia ser tratada de maneira diversa nos é apresentada pela justificação de voto vencido proferida pelo Ministro Raymundo de Souza Moura. Em seu voto, aponta que:

\footnotetext{
Não se pode, portanto, dizer que o movimento grevista seja em razão da deficiência desta justiça, mas, sim, como afirma o Recorrente, como uma consequência da própria lei, que tolhe a livre negociação entre as partes. $\mathrm{O}$ movimento de que dão notícia estes autos tem, pois, como acentua o Recorrente, o caráter não de uma reação pura e simples contra a lei, mas de um meio de apelar no sentido de uma reforma da legislação salarial.
}

Embora também rejeite a preliminar de inconstitucionalidade da Lei 4.330/64, o Ministro considera a particularidade do movimento grevista sub judice para a análise de sua legalidade. Não se põe como escravo da lei, como fez o relator. Desta maneira, reconhece que embora os trabalhadores não tenham respeitado todas as formalidades previstas em lei, esta desobediência não ocorreu como ato de violência. Conclui que "não pode ser configurado o ilícito se não houve a má fé, a intenção maliciosa" e, como consequência, vota pela reforma da decisão de origem, reconhecendo a legalidade da greve.

Mesmo com o resultado desfavorável da greve no judiciário, seus resultados práticos foram positivos. Além do ganho material de quase $20 \%$ de acréscimo salarial, as greves promoveram um desenvolvimento da consciência coletiva e do espírito de solidariedade dos trabalhadores, além de projetar esta categoria como importante força política no país.

Esta vitória política vai muito além da conquista salarial. A dificuldade de organizar e deflagrar uma greve deste porte representa um confronto à forma como o governo tratava até então os trabalhadores. Como aponta uma reportagem jornalística da época: 
(...) os patrões já disseram que atendem aos trabalhadores desde que 'o gesto de benevolência' não represente qualquer ônus, ou seja, permita ao Estado o reajustamento dos preços dos bens que produzem para custear a elevação salarial reclamada. Transferem assim a culpa pela intransigência ao governo e resistem. O Estado, por sua vez, não só resiste como é de seu interesse que o patrão também resista, a partir da rígida doutrina de comportamento político segundo a qual não deve ceder sob pressão. ${ }^{111}$

A ideia era de que o sucesso deste movimento grevista "ofereceria margem de segurança a outras categorias profissionais de obter sucesso com desencadeamento de movimento da mesma natureza"1 ${ }^{12}$.

A importância que esta greve teve na política nacional transparece também na forma como o governo abordou a questão. Após a decisão do TRT/SP, que decidiu pela ilegalidade do movimento grevista, o governo expediu uma nota oficial afirmando que, em nome da paz social ${ }^{113}$, utilizaria todos os recursos disponíveis para conter os manifestantes.

\begin{abstract}
"Deve ser observado ainda que a nota oficial do Ministério do Trabalho comunica, finalmente, aos trabalhadores, que serão utilizados todos os meios legais, o que inclui forças policiais, a fim de garantir àqueles que desejarem exercer suas atividades profissionais - o direito de trabalhar. A greve passa, consequentemente, a ser matéria prioritária da presidência da república, devendo a solução ser conduzida pelo palácio do planalto" ${ }^{114}$.
\end{abstract}

O sucesso desta greve em 1978 repercutiu positivamente e possibilitou a execução de movimentos maiores e mais amplos nos anos seguintes. Em 1979 foi deflagrada outra greve, que se iniciou no dia 13 de março. A experiência do ano anterior resultou em um "fortalecimento da onda grevista, que passou de cerca de meio milhão de trabalhadores, em 1978, para mais de 3 milhões, em 1979"115. Movida pelos sindicatos dos

\footnotetext{
${ }^{111}$ Folha de São Paulo, 22 de maio de 1978, p.2.

${ }^{112}$ Ibidem, p.2.

${ }^{113}$ Esta utilização distorcida do conceito de "paz social", justificadora das atrocidades cometidas no regime militar e de outras cometidas ainda hoje, só nos recorda da letra da música "Minha alma", da banda O Rappa: A minha alma tá armada e apontada/ Para a cara do sossego / Pois paz sem voz,/ Não é paz é medo. As vezes eu falo com a vida,/ As vezes é ela quem diz:/"Qual a paz que eu não quero conservar/ Pra tentar ser feliz ?"

${ }^{114}$ Folha de São Paulo, 22 de maio de 1978, p.2.

${ }^{115}$ BRAGA, Ruy. Op. cit., p. 169.
} 
metalúrgicos de São Bernardo, Santo André e São Caetano, dela decorreu o processo TRT/SP 48/79. Trata-se de dissídio coletivo movido pela Procuradoria Regional do Trabalho da $2^{a}$ Região onde se discute, além das diversas reivindicações profissionais da categoria, a legalidade do movimento grevista.

Apesar da importância deste movimento grevista, a questão de sua legalidade é tratada de forma superficial no voto do relator Marcos Manus. Novamente a greve foi declarada ilegal pelo Tribunal Regional do Trabalho de São Paulo, sob o argumento de que não foram atendidas todas as exigências impostas pela Lei 4.330/64, tais como "convocação por Edital da Assembléia, voto secreto, com apuração pela Procuradoria, prova de quorum, prazos da lei". Entretanto, apesar desta declaração de ilegalidade do movimento, a greve foi novamente vitoriosa, eis que as reivindicações profissionais discutidas no dissídio coletivo foram julgadas favoravelmente à categoria. A vitória ocorreu também no campo político, como aponta Ruy Braga:

\footnotetext{
O processo grevista de março mostrou ao patronato e ao regime militar que não seria fácil desmobilizar o ativismo do ABCD. Ao mesmo tempo, a greve de 1979 serviu para eliminar quaisquer dúvidas a respeito do papel desempenhado pelo Estado naqueles conflitos industriais do final dos anos 1970. A imagem de uma aliança empresarial-militar forjada contra os operários foi se consolidando na consciência metalúrgica. No tocante à burocracia sindical, a lição era clara: não seria possível alcançar concessões sem o recurso à greve. ${ }^{116}$
}

Logo após o fim do movimento paredista de 1979, a categoria dos metalúrgicos iniciou debates sobre a realização de uma nova greve no ano seguinte. Em 16 de março de 1980 a categoria aprova nova paralisação para o dia $1^{\circ}$ de abril. Contudo, esta greve não logrou vitórias como nos anos anteriores.

No ano de 1980, os trabalhadores, apesar de melhor organizados e taticamente estruturados, não conseguiram se sobrepor à intransigência dos empresários e às pressões políticas e militares do governo. A impossibilidade de dialogo por parte dos empregadores pôde ser constatada na reunião de negociação entre representantes de empregados e de empregadores.

${ }^{116}$ BRAGA, Ruy. Op. cit., p. 168. 


\begin{abstract}
A FIESP foi representada na mesa-redonda apenas por seus advogados e Benjamim Monteiro colocou logo de início que a participação da entidade na mesa-redonda devia-se apenas ao atendimento da formalidade legal. "As negociações estão definitivamente encerradas, e nos recusamos a discutir nessa mesa", afirmou Monteiro. "Nossa conciliação reside apenas num ponto: retorno imediato ao trabalho", disse. ${ }^{117}$
\end{abstract}

Novamente foi instaurado dissídio coletivo (processo TRT/SP 58/80), tendo como principal suscitante a FIESP e como principal suscitado o sindicato dos metalúrgicos de São Bernardo. Novamente a greve foi declarada ilegal pelo Tribunal Regional do Trabalho da $2^{\mathrm{a}}$ Região. Note-se que o voto foi apresentado de forma telegráfica, limitandose o Tribunal a sustentar que "o movimento paredista foi deflagrado ao arrepio dessa legislação". Estranhamente, sequer aponta o voto quais foram os atos que os trabalhadores realizaram ou deixaram de realizar e quais normas violaram para receber tal apenamento.

Contudo, destaca-se o voto vencido do magistrado Ruben Ferrari, que votou a favor da legalidade do movimento grevista. Corretamente aponta em seu voto que estava ocorrendo uma fixação apriorística de ilegalidade dos movimentos sindicais, o que acabou se repetindo no presente caso:

\footnotetext{
Se não cabe, a qualquer órgão judicante, mesmo aos Tribunais do Trabalho em dissídio coletivo, declarar uma situação de ilegitimidade abstrata e a greve constitui remédio que a Lei Magna admite, sua eclosão, excetuadas as hipóteses restritivas expressamente contempladas na lei ordinária, não há de gerar prática censurável, capaz de sujeitar toda uma categoria indiscriminada de trabalhadores, mas tão só quantos hajam, durante a parede, incorrido em excessos suscetíveis de apenamento, tarefa estranha ao dissídio coletivo.
}

A decisão sobre a ilegalidade da greve foi mantida pelo TST. O relator Orlando Coutinho, ao invés de esclarecer sua posição em relação aos fatos que levaram à ilegalidade do movimento, preocupou-se em discorrer sobre a eficácia da Lei 4.330/64. Segundo ele "ainda que necessária a sua alteração, porque ultrapassada e vencida em eficácia pela realidade, e ser urgente o ajustamento aos fatos sociais modernos, por ora é a lei vigente". A greve foi declarada ilegal pelo judiciário e, ao contrário das anteriores, não teve um resultado tão satisfatório.

\footnotetext{
${ }^{117}$ Folha de São Paulo, 12 de abril de 1980, p.14
} 
A greve de 1980 durou 41 dias, durante os quais 15 líderes metalúrgicos foram presos com base na Lei de Segurança Nacional, além de ter ocorrido intervenção estatal nos sindicatos. A atuação do poder judiciário foi essencial para a vitória do governo. Como aponta uma matéria jornalística da época:

Embora mesmo antes da consideração da ilegalidade do movimento o ministro
do Trabalho pudesse decretar intervenção nos sindicatos e destituir seus
dirigentes dos cargos, há um procedimento internacional que "recomenda" que as
medidas punitivas devam ser adotadas após um pronunciamento judicial.
Considerando a importância internacional do movimento sindical paulista, essa
parece ter sido a atitude adotada pelo governo: esperar a decisão do tribunal, cujo
acórdão deverá conter o enunciado das "medidas administrativas" que o governo
deve adotar para fazer cumprir a sentença do julgamento de "ilegalidade" do
movimento grevista.

Assim, a declaração de ilegalidade da greve serviu de suporte para o governo militar reprimir os trabalhadores sob a (falsa) égide de imparcialidade que reveste a legalidade e cumprimento da decisão judicial. Em tom de ameaça - e com certa desfaçatez - afirmou o ministro do Trabalho que "Se for necessário cumprir a lei eu a cumprirei, porque eu sou um democrata. E nós, que amamos a democracia, temos que colocar o dever acima de tudo. Serei inflexível, se for necessário" ${ }^{119}$. Esta afirmação do ministro do Trabalho de estrito cumprimento da lei para justificar o posicionamento repressivo contra movimentos grevistas não deve ser vista apenas como um ato característico de nossa época ditatorial. Se observarmos atentamente, inclusive através das análises jurisprudenciais deste trabalho, poderemos perceber que tais táticas continuam a ser politicamente utilizadas contra grevistas.

A preocupação do governo com a interferência dos trabalhadores na esfera política e econômica tornou a repressão a estes movimentos prioridade. Mas não eram apenas os militares que estavam preocupados com a força dos trabalhadores; os detentores dos meios de produção estavam descontentes com as reivindicações trabalhistas, que representavam uma redução de sua margem de lucro. Notável a matéria jornalística da época intitulada "Preocupação na Alemanha", na qual consta que uma das maiores

\footnotetext{
${ }^{118}$ Folha de São Paulo, 15 de abril de 1980, p.20.

${ }^{119}$ Idem, 12 de abril de 1980, p.14.
} 
preocupações dos investidores alemães, manifestadas diretamente ao ministro da Indústria e Comércio, era dos "efeitos dos movimentos sindicais na condução da política econômica". À época esta preocupação foi logo acalmada pelo governador do Rio Grande do Sul, que afirmou "não acreditar que o movimento sindical possa interferir negativamente na estratégia brasileira" ${ }^{120}$.

A greve de 1980 terminou sem obter suas principais reivindicações. Os trabalhadores enfrentaram forte repressão e "não conseguiram suplantar a determinação da aliança empresarial-militar de não atender nenhuma reivindicação" ${ }^{121}$. Segundo Ricardo Antunes, esta greve:

(...) acabou por se configurar em inegável derrota política do movimento operário. A prisão das lideranças e seu enquadramento na Lei de Segurança Nacional, bem como a perda do organismo sindical, a que se seguiu um processo de desorganização desse núcleo moderno da classe operária brasileira e do "novo sindicalismo", com repercussões marcantes e negativas no conjunto do movimento grevista daquele ano que então se iniciava - e que a partir daí ingressou num período de acentuado refluxo -, tudo isso refletiu e manifestou, ao contrário das vitórias inquestionáveis de 1978 e 1979, uma forte derrota política sofrida pelo movimento operário metalúrgico. ${ }^{122}$

Entretanto, a greve teve também importantes consequências para os trabalhadores. A repressão a este movimento gerou debates no seio político brasileiro, consagrando a questão trabalhista no centro da discussão da redemocratização brasileira. Segundo o deputado João Cunha, que convocou o ministro do Trabalho para prestar esclarecimentos sobre as greves,

\footnotetext{
"(...) neste instante, quando no $\mathrm{ABC}$ 'se trava a luta de morte entre a política desse governo e os trabalhadores, penso que a democracia que queremos começa a ser construída mais no estádio de Vila Euclides, em São Bernardo, do que propriamente neste Congresso, pelas mãos insensíveis da maioria dos integrantes da classe política'. Acrescentou ainda que a vinda do ministro do Trabalho,
}

\footnotetext{
${ }^{120}$ Folha de São Paulo, 15 de abril de 1980, p.20.

${ }^{121}$ BRAGA, Ruy. Op. cit., p. 169.

${ }^{122}$ Antunes, Ricardo. A Rebeldia do Trabalho - O confronto operário no ABC paulista: as greves de 1978/1980. 2ªed. Campinas, Unicamp, 1992, p.96.
} 
ontem, a Brasília, em avião da empresa Camargo Correa, 'e sua falsa sibilina, ameaçadora e descortês, mostram de que lado está este governo"' ${ }^{123}$.

As consequências destas greves no $\mathrm{ABC}$ paulista foram inegavelmente positivas para a classe trabalhadora brasileira. Esta vitória não se resume a condições materiais e de trabalho; foi uma vitória verdadeiramente política, que contestou posições governamentais e a política econômica do país.

A busca por um caráter transformador da realidade social através da atuação política dos trabalhadores como classe social representou o desenvolvimento de uma consciência coletiva de inegável importância. A Constituição de 1988, profícua em matérias sociais e que garantiu o amplo direito de greve, é reflexo desta força política adquirida pelos trabalhadores. E o direito de greve que a Constituição assegura somente pode ser interpretado neste sentido amplo que a construção histórica lhe confere.

\section{2 - A greve nacional dos petroleiros de 1995}

Uma análise do acórdão proferido em decorrência da greve dos petroleiros de 1995 só pode ser corretamente realizada após uma breve imersão em sua conjuntura histórica, sobretudo em relação à intensa fase de privatizações que ocorria desde o início da década de 90.

Com a edição da Lei 8.031 de 1990 pelo governo Collor iniciou-se no Brasil um processo de privatição de empresas estatais fortemente influenciado pelas regras estabelecidas em 1989 por aquilo que se convencionou chamar de "Consenso de Washington". O Consenso de Washington foi um conjunto de regras fixadas por economistas liberais que viam no modelo de Estado de bem-estar social a causa da estagnação econômica da década de 80. Estas regras objetivavam reduzir a influência estatal na economia - inclusive no que diz respeito à legislação trabalhista- e majorar o poder do capital através de facilidades de investimento e circulação.

Fundamentado o programa econômico nacional neste modelo neoliberal, a privatização de empresas estatais era o primeiro passo para a ampla abertura comercial e para os investimentos estrangeiros diretos. A flexibilização econômica e trabalhista, juntamente com o desmonte dos mecanismos se seguridade social, eram os passos

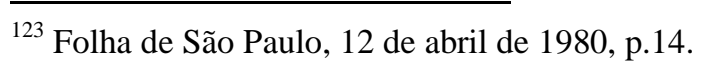


seguintes no avanço desta nova política. Neste período inicial foram privatizadas empresas como a VASP, a USIMINAS, a Companhia Siderúrgica Nacional e a Embraer, e o governo sinalizava que o ritmo das privatizações não cessaria. A privatização da Petrobrás e o fim do monopólio estatal para exploração do petróleo estavam na pauta do debate político.

Ante o temor de privatização da Petrobrás e frente ao processo de reestruturação da empresa pelo governo, a categoria dos petroleiros iniciou em setembro de 1994 um movimento paredista reivindicando aumento salarial, participação nos lucros e garantia de manutenção dos postos de trabalho.

Ante o impasse entre empregados e empregador, o conflito foi levado à apreciação do judiciário, tendo o TST declarado a greve abusiva, fixando pesada multa diária ao sindicato obreiro, e aplicando um reajuste menor do que aquele inicialmente proposto pela própria reclamada. Esta greve foi acompanhada de perto pelo poder executivo federal, que a tratou como se fosse um movimento corporativista buscando a manutenção de privilégios indevidos. Esta decisão judicial marcou uma vitória no caminhar neoliberalizante que o governo traçava.

Contudo, a declaração de abusividade do movimento não desmobilizou a categoria, que prosseguiu com sua paralisação. Este movimento logrou manter sua força a ponto de conquistar três acordos. O primeiro, firmado em 05 de outubro de 1994 na cidade mineira de Juiz de Fora pelos representantes sindicais com o então presidente Itamar Franco e outros representantes do executivo, possuía sete cláusulas que tratavam de questões como reposição salarial, não punição dos grevistas e readmissão de trabalhadores demitidos.

O segundo acordo foi firmado em 11 de novembro entre o sindicato e o Ministro de Minas e Energia e a Petrobrás, ratificando os termos do acordo anterior e os expandindo ao longo de 33 cláusulas, entre as quais a anistia dos empregados demitidos no passado. Por fim, foi assinado um terceiro acordo entre a Federação Única dos Petroleiros e o Superintendente Adjunto do Serviço de Recursos Humanos da Petrobrás. Encerrada a greve, aparentemente os trabalhadores haviam obtido bons frutos com este movimento.

Contudo, esta aparência não se concretizou. Os acordos firmados jamais foram cumpridos. Ao fim de 1994, com a posse de Fernando Henrique Cardoso como presidente da República, o novo governo sinalizou que não haveria espaços para novas negociações. 
O governo também "negava validade jurídica e a viabilidade dos acordos realizados entre essas categorias e o governo anterior" ${ }^{\text {"124. }}$.

Sob esta conjuntura iniciou-se a greve dos petroleiros no dia 03 de maio de 1995. O objetivo da greve não se limitava à exigência de cumprimento dos três acordos firmados, mas também pretendia demonstrar ao governo a força mobilizatória dos petroleiros, sinalizando que estes não aceitariam imposições neoliberalizantes na Petrobrás, que trariam inevitavelmente a precarização nas relações de trabalho.

Esta greve deflagrada pelos petroleiros ao longo de todo o território nacional é um dos casos mais significativos de como o legítimo exercício do direito de greve garantido pela Carta Magna de 1988 encontra indevidas limitações impostas pelo poder judiciário e pelo governo.

A decisão proferida pelo TST em 09 de maio de 1995 é composta por três votos. O primeiro voto é do ministro relator Ursolino Santos. Os outros dois são votos convergentes juntados respectivamente pelos ministros Almir Pazzianotto Pinto e Armando de Brito.

Tanto no voto do relator quanto do ministro Pazzianotto podemos ver como um discurso puramente dogmático, que busca sustentar-se apenas em argumentos aparentemente jurídicos, na verdade transparece como suporte para interesses políticos. No terceiro voto o ministro Armando de Brito, ao contrário de seus colegas, deixa evidente que se trata de uma questão de cunho político, ignorando por completo a análise legal do movimento paredista.

No voto do ministro relator o argumento preponderante para a declaração de abusividade do movimento sustenta-se na ideia de que "a eclosão da greve ocorreu na vigência de sentença normativa", contrariando o disposto no artigo 14 da Lei 7.783/89.

Os grevistas apontam como um dos motivos preponderantes do movimento o descumprimento por parte da empresa dos acordos firmados em 1994. Evidente que a greve do ano anterior só se encerrou em decorrência dos acordos assinados. O que se verificou, entretanto, é que com a mudança da cúpula do poder executivo buscou-se um meio de descumprir tais acordos.

${ }^{124}$ RIZEK, Cibele Saliba. A greve dos petroleiros. Revista Praga. São Paulo, setembro de 2008, p.97. 
Os grevistas não buscavam rediscutir a sentença normativa, mas sim exigiam o cumprimento dos acordos de 1994. Indiferente o fato dos acordos tratarem ou não de questões relativas à sentença normativa; o que se pretendia era assegurar a validade do que fora acertado entre as partes após intensas deliberações. O relator confunde finalidade com consequência. A finalidade da greve (exigir o cumprimento dos acordos) não pode ser confundida com a consequência prática da aplicação dos acordos (eventual alteração do disposto na sentença normativa).

Assim, mesmo sob a ótica restritiva da lei 7.783/89 o argumento exposto não se justifica, eis que, por ser motivada pela superveniência de fato novo que modificou substancialmente a relação de trabalho (não cumprimento de acordos), a greve se encaixa na excludente do parágrafo único, II, do artigo 14.

Absurdas também as alegações expostas pelo ministro Almir Pazzianotto Pinto $^{125}$ de que os acordos firmados não tem validade jurídica por não serem firmados por pessoas devidamente competentes. O primeiro acordo foi firmado pelo presidente da república e o segundo pelo ministro das Minas e Energia, sendo que a Petrobrás participou diretamente dos segundo e terceiro acordos. Em todas estas negociações a Petrobrás estava ciente dos termos negociados e em momento algum alegou invalidade. Afirmar que nenhuma tratativa tem validade por não ter sido "ratificada posteriormente pela Presidência da Petrobrás" e com isso invalidar o movimento grevista significa conceder a esta cúpula empresarial o poder de autorização do direito de greve.

Seguindo a lógica exposta no voto, bastaria a presidência da Petrobrás se furtar da ratificação de qualquer acordo para excluir permanentemente a legitimidade dos grevistas para pressionar sua execução. Há aqui uma deturpação da lógica jurídica, pois há um prejuizo ao exercício de um direito dos trabalhadores em decorrência de um ato unilateral do empregador. Se o objetivo da greve é assegurar a aplicabilidade dos acordos firmados, o fato deles terem sido ou não firmados pela presidência da empresa não pode

\footnotetext{
${ }^{125}$ Cumpre aqui destacar a surpresa com relação ao voto proferido pelo ministro Pazzianotto. Após anos atuando como jurista preocupado com as causas operárias, a expectitiva era de que seu voto contivesse uma leitura mais progressista do direito de greve. Em 1978, Pazzianotto foi apontado pelos grevistas de São Bernardo como um dos candidatos ao legislativo "comprometidos com as lutas populares" (conforme ABCD Jornal, n²2, 1978, p.4-5). Pazzianotto foi também o advogado dos sindicatos dos trabalhadores que fez a sustentação oral no julgamento da greve de 1979 (conforme notícia "TRT decide pela ilegalidade", publicada pelo jornal Folha de São Paulo em 15/04/1979, p.21), defendendo à época o exercício do direito de greve contra a posição majoritária do Tribunal Regional do Trabalho de São Paulo, direito de greve que acabou por negar em seu voto no caso dos petroleiros.
} 
representar óbice para a greve, eis que seu objetivo é justamente revestir tais acordos de todas as formalidades necessárias para seu inquestionável cumprimento.

Em seu voto, o ministro relator também entendeu haver "fortes evidências" de que não ocorreu a adequada prestação de serviços necessários ao atendimento das necessidades inadiáveis da comunidade. Este posicionamento também foi adotado nos demais votos, que citam o desabastecimento de produtos derivados do petróleo como uma das provas da abusividade do movimento, por não assegurar a prestação mínima de serviços à comunidade.

Contudo, em auditoria realizada pelo Tribunal de contas da União na Petrobrás, que objetivava quantificar as perdas sofridas pela empresa em decorrência desta greve, foi constatado que os desabastecimentos de gás de cozinha e gasolina não ocorreram por causa do movimento paredista, mas sim por causa da retenção destes produtos pelas distribuidoras.

\footnotetext{
"Quanto à distribuição, foi verificado que a queda nos volumes de derivados entregues às distribuidoras, com exceção da nafta, não foi superior a 16,5\% no mês de maio, com tendência, conforme dados preliminares obtidos, à normalização no mês seguinte. Em razão disso, observa o Grupo Auditor, percebe-se claramente que há indícios de que as distribuidoras retiveram produtos, especulativamente, principalmente o GLP (gás de cozinha) e a gasolina, pois a redução havida na distribuição não seria suficiente para causar os contratempos verificados nas grandes cidades, com a população em busca desses produtos." ${ }^{126}$.
}

Note-se que o motivo gerador da comoção popular contra este movimento paredista - a falta de bens derivados - não foi ocasionado pela paralisação dos trabalhadores, mas sim por parte dos próprios empresários. A questão nunca chegou a ser noticiada pela grande midia e não há notícias de punições aos responsáveis pelo desabastecimento. $\mathrm{Na}$ prática, os únicos que foram punidos com esta atitude dos distribuidores foram os próprios trabalhadores, que perderam apoio popular em seu movimento.

${ }^{126}$ Tribunal de Contas da União, Decisão 0537/1995 Ata 48 - Plenário, 25/10/1995. 
O tratamento dado a esta greve foi claramente político. As reivindicações dos trabalhadores confrontavam os rumos da política neoliberalizante que ocorria desde o governo Collor e que encontrou sua expressão máxima no governo FHC.

Não se trata simplesmente da validade jurídica dos documentos assinados, ao contrário do que fizeram parecer os votos do relator e do ministro Almir Pazzianotto Pinto. Quem melhor expôs a litigiosidade desta greve foi o ministro Armando de Brito.

Seu voto, apesar de parecer mais um manifesto do que uma decisão judicial, possui ao menos a virtude de deixar claras as motivações que levaram o judiciário a declarar a ilicitude da greve dos petroleiros. O ministro sequer procurou realizar malabarismos jurídicos como seus colegas para esconder um julgamento que já possuia resultado definido antes mesmo da propositura do litígio. A leitura de seu voto é essencial para entender o deslinde da greve dos petroleiros.

Logo no primeiro parágrafo de seu voto, aponta que "tomando ciência pela imprensa, pela ampla publicidade na televisão, ouvindo pronunciamentos no Congresso Nacional, sabemos que está deflagrado um movimento político-sindical para se opor às reformas constitucionais propostas pelo Governo". Desde já fica claro que a formação de vontade do ministro tem uma base probatória parcial: a mídia. Como pode ser visto ao longo do voto, em momento algum analisa as motivações dos obreiros de modo a confrotálas com o exposto pela imprensa.

Note-se que foi constante o ataque ao movimento grevista pela imprensa. Segundo Francisco de Oliveira:

\footnotetext{
Já em junho de 1995, a greve dos petroleiros foi unanimemente denunciada pela imprensa como a mais clara demonstração de como o corporativismo pode atuar contra os direitos dos consumidores. Mas não se disse que o governo, ao querer derrotá-los - o que, afinal, conseguiu - visava, de uma só tacada, acabar com os direitos dos trabalhadores, submetendo-os a uma discutível 'razão de estado', e açular a opinião pública contra o monopólio estatal do petróleo para levar o Congresso a votar, sem restrições, sua proposta de desmontagem da Petrobrás o que acabou fazendo. ${ }^{127}$
}

${ }^{127}$ OLIVEIRA, Francisco de. Corporativismo: Conceito ou Emplastro, In Democracia Viva, Rio de Janeiro: Ibase, n³, Julho de 1998, p.07. 
Afirmou ainda o ministro que os grevistas "querem exaurir a sociedade, vencendo-a pelo cansaço (...) na defesa do lesivo sistema corporativista-imobilista (...) trazendo danos graves à economia nacional".

Ao contrário do que faz parecer a decisão, não houve um verdadeiro embate democrático sobre a questão. Com a manipulação da distribuição de gás e ocultamento midiático sobre as pretensões dos grevistas, o governo buscou influenciar a opinião pública. Ao invés de reprimir as greves com a arbitrariedade ditatorial da época militar, buscou o novo governo influenciar a opinião pública para revestir como democráticas suas ações igualmente arbitrárias.

A atitude repressiva do governo já havia sido muito bem arquitetada. Como aponta Roberto Verás de Oliveira:

Com as medidas que tomou de imediato, o governo FHC indicou como trataria o
caso: preventivamente, já havia importado petróleo da Venezuela e da Argentina;
através das direções das estatais, solicitou do TST a condenação da greve como
abusiva; por meio de decreto da Presidência da República, regulamentou os
processos punitivos contra grevistas no serviço público federal; as negociações
foram assumidas diretamente pelo Ministério das Minas e Energia, para unificar
a conduta do governo. ${ }^{128}$

Diversos apontamentos são necessários ante estas atitudes do governo. Inicialmente com relação à importação preventiva de petróleo de países vizinhos. Ora, a necessidade de manutenção de serviços essenciais visa unicamente manter a prestação de serviços mínimos necessários à comunidade. Se já havia estoques preventivos, qual a razão de fixação de $30 \%$ dos funcionários para prestação de serviços? Como já visto, o desabastecimento tampouco pode ser relacionado à greve, já que decorreu de retenção destes produtos pelas distribuidoras. A declaração de abusividade do movimento por não terem os trabalhadores assegurado a prestação mínima de serviço não se justifica.

Ademais, a designação do Ministro das Minas e Energia para assumir as negociações com os grevistas desfazem outra falácia jurídica da decisão: a de que os compromissos firmados com os trabalhadores não tem validade por não terem sido assinados por pessoa competente. Ora, um destes tratados - o mais abrangente, diga-se de

${ }^{128}$ OLIVEIRA, Roberto Verás de. Sindicalismo e Democracia no Brasil: do Novo Sindicalismo ao Sindicato Cidadão. São Paulo: Annablume, 2011. p.257. 
passagem - foi assinado justamente pelo Ministro das Minas e Energia. A capacidade do governo para cumprir os acordos é evidenciada em seus esforços para desarticular a greve. Se o governo não tem poderes e interesses na Petrobrás, não se justificaria de maneira alguma as intervenções que realizou.

Em seu voto, o ministro Armando de Brito parece ignorar o fato de que a ditadura militar no Brasil já havia acabado e que o país estava vivendo sob a égide de uma nova constituição. Seu posicionamento contra os movimentos grevistas pode ser visto através da negativa a priori de validade de uma greve:

\footnotetext{
Julgará este Tribunal, em seguida, a greve dos Eletricitários, a dos Portuários, a dos Metroviários em São Paulo, a dos Correios, a dos Ferroviários e, quiçá, de outras e outras categorias que exercem atividades essenciais, principalmente aquelas ligadas à CUT e relacionadas com o Estado por vínculo administrativo. Seria de se indagar se pretendem, pela força, tais políticos-sindicalistas governar o País; mas, inviabilizando-o antes como Nação.
}

O ministro entende que as greves são um atentado à nação brasileira, uma forma despótica de influência na formação dos poderes que governam o País. A greve não é vista como um direito, mas sim como um ato abusivo que pode se revestir de caráter legal caso preencha inúmeros requisitos - entre eles alguns não escritos, como não estar relacionada com o Estado por vínculo administrativo e não estar ligada à CUT. Há uma inversão na análise do fato social. A greve é tratada como a legítima defesa no direito penal; assim como a legítima defesa precisa ser provada por aquele que a exerceu, sob pena da ação ser considerada um delito; a greve legal deveria ser provada, sob pena de ser considerada um ato social abusivo.

Ao contrário do entendimento do ministro, a priori a greve sempre é legal. Há muito deixou a greve de ser considerada um delito ou o simples exercício de uma liberdade. A greve é um Direito Social fundamental constitucionalmente garantido e como tal deve ter seu exercício assegurado pelos órgãos da estrutura de poder. O exercício de um direito não se limita à mera possibilidade de ação, mas compreende também garantias do Estado para assegurar que os destinatários deste direito possam exercê-lo. Ao repreender a greve abstratamente como o fez em seu voto, o ministro renega todo o acertamento social que construiu a Constituição de 1988. 
Se a greve já é tratada de forma repressiva por este ministro, seu exercício com reivindicação política é visto como algo intolerável. Sustenta em seu voto que "a questão da greve política, portanto, precisa ser olhada como matéria diretamente ligada à sobrevivência da ordem democrática, ou seja, como verdadeira questão de segurança nacional".

Ao tratar a greve como "questão de segurança nacional" o ministro revela ainda interpretar a sociedade através de olhos ditatoriais, olhar que reflete a influência de normas produzidas pelo militares para conter o exercício de movimentos grevistas, como o Decreto-Lei 898/69 ${ }^{129}$.

A aversão deste ministro ao direito de greve é tamanha que chega a sugerir a eliminação de suas garantias constitucionais. Sustenta que "devem ser ceifadas da Constituição as normas dúbias em que, com audácia, a organização sindical lastreia suas posições e tumultua", afirmando ainda que estas normas geram "insegurança para a vida dos cidadãos e da coletividade". Chega a sustentar que "é necessário, sim, e urgente, expungir o texto quase irresponsável inserido no caput do art.9 da Constituição".

O ministro reconhece que as normas que regulam o direito de greve não trazem nenhuma limitação ao seu exercício. Contudo, para desqualificá-lo primeiramente chama o texto Constitucional de "dúbio". Em seguida, já reconhecendo que não há contradição alguma, aponta esta amplitude do direito como "quase irresponsável". Por fim, expõe que se deve alterar o texto legal para eliminar a possibilidade "da greve por qualquer motivo, em qualquer oportunidade a critério das lideranças".

Ora, ao bradar por uma mudança no texto constitucional, reconhece o ministro que o atual texto permite aos grevistas protestarem amplamente, cabendo a eles decidir sobre o motivo e a oportunidade de seu exercício. Por não terem sido acolhidos os seus apelos de alteração na Carta Magna, é evidente que ainda hoje o exercício do direito de greve deve ter a amplitude temida pelo ministro.

\footnotetext{
${ }^{129}$ Decreto-Lei 898/69, Art. 40: Cessarem funcionários públicos coletivamente, no tôdo, ou em parte, os serviços a seu cargo: Pena: detenção de 8 meses a 1 ano.

Parágrafo único. Incorrerá nas mesmas penas o funcionário público que, direta ou indiretamente, se solidarizar aos atos de cessação ou paralisação de serviço público ou que contribua para a não execução ou retardamento do mesmo.
} 
A declaração de abusividade ocorreu em total desrespeito às normas constitucionais. Sequer se deu ao trabalho de revestir de falsa legalidade seu julgado, como o fizeram seus demais colegas em seus votos; ao contrário, reconheceu a existência de preceitos legais que resguardavam as ações dos trabalhadores mas, por entender que tais normas devem ser alteradas, não as aplicou. Exerceu o ministro papel legislativo que sequer poderia ser exercido pelo poder constituinte derivado, eis que se trata de direito fundamental. Como dito, seu voto não é uma peça jurídica, mas um verdadeiro desabafo de alguém inconformado com garantias democráticas trazidas pela Constituição cidadã.

Trata-se de uma externalização absurda não apenas porque limita indevidamente um Direito Social constituído - como a maioria dos votos que tratam de greves políticas no Brasil -, mas absurdo sobretudo por exigir a eliminação de um artigo constitucional que trata de questão fundamental.

O ministro nega a lógica principiológica da ordem jurídica, obstruindo a aplicabilidade de um direito constitucional por entender que este deveria ser alterado. Não nega simplesmente a aplicabilidade do direito ao caso concreto, mas nega o próprio direito em si, seu texto e sua construção. Para o ministro, a formação da assembleia constituinte, os debates realizados, o confronto de forças e a vontade popular nada significam. O importante seria apenas a edição de normas "em defesa da sobrevivência da ordem jurídica e da sobrevivência das instituições democráticas". Contudo, não percebe o jurista a contradição fatal em seu voto.

Ao negar a aplicabilidade de uma norma constitucional, nega a própria funcionalidade da ordem jurídica. Ora, como defender o sistema legal negando a própria construção deste sistema? Como unilateralmente renega o texto jurídico básico por entendê-lo "irresponsável", se irresponsabilidade maior é atentar contra a segurança jurídica dos trabalhadores, que exerceram o mais básico de seus direitos com a certeza de estarem agindo nos termos da lei para, finalmente, se verem como atores de um ato declarado abusivo, declaração esta em contradição com todo o suporte normativo pátrio? Como se pode falar em sobrevivência da ordem jurídica se ao exercer seu direito de greve os trabalhadores sempre terão a incerteza do posicionamento dos tribunais? Assim como Joseph K. em sua odisseia pelos meandros do judiciário, os trabalhadores nunca teriam segurança jurídica, eis que o exercício do direito de greve estaria sempre condicionado a posicionamentos kafkianamente arbitrários de nossos tribunais. 
Além disso, como falar em "sobrevivência das instituições democráticas" se o ministro nega a formação constitucional da norma? Ao negar sua aplicabilidade por motivos subjetivos, objetivamente nega todo o processo de construção deste direito, desde os movimentos populares que pressionaram o poder político, passando pelos debates do poder constituinte, até a votação final do texto constitucional. A sobrevivência das instituições democráticas depende do respeito às normas constitucionais, em especial aquelas de caráter social. Ao justificar seu voto na defesa da ordem jurídica e da legalidade, reveste-se o ministro como defensor daquilo que nega da mesma maneira que a ditadura apresentou-se como defensora da democracia.

Continua ainda o ministro defendendo que "esperar que se cometam abusos e mais abusos para reprimir os responsáveis segundo as penas da lei, conforme escrito no $\S 2^{\circ}$ do mesmo art. $9^{\circ}$, é postergar uma solução, é quase projetar uma impunidade". Ora, segundo esta lógica, desnecessária a configuração de ilegalidade para a punição. Desnecessária a lei. Desnecessários os juízes. Afinal, para o ministro o importante não é a legalidade, mas a manutenção da ordem - ordem aqui entendida como status quo, como manutenção de privilégios que sustentam a desigualdade social. Sabemos quantos abusos foram cometidos em nome desta lógica, lógica esta distante de qualquer Estado que se pretenda Democrático de Direito.

Reconhece o ministro a existência, validade e a amplitude do direito de greve no texto constitucional, porém se nega a aplicá-lo por conceito pessoal. Se em todo este caso envolvendo a greve dos petroleiros de 1995 há um exercício indevido de pressão política, ele foi exercido por este magistrado e pelo governo contra os trabalhadores. Em sua fúria [in]contida, abandona o ministro as mais basilares lógicas jurídicas em nome de um objetivo parcial.

Após a declaração de abusividade do movimento grevista pelo judiciário, houve aplicação de pesadas multas aos sindicatos (estimadas em $\mathrm{R} \$ 35,7$ milhões de reais por sindicato), demissão de funcionários que estavam mobilizados, descontos salariais e até mesmo intervenção militar em postos de extração de petróleo, como ocorreu nas refinarias de Paraná (REPAR), Paulínia (REPLAN), Mauá (RECAP) e São José dos Campos (REVAP). Mesmo sob intensa pressão, os petroleiros mantiveram sua mobilização por 32 dias, até o dia 02 de junho de 1995, quando decretaram o fim do movimento paredista. 
Apesar de todos os reveses sofridos, historicamente a greve representou uma vitória aos petroleiros. Se a greve não foi suficiente para interromper a aplicação das regras fixadas pelo Consenso de Washington, o poder de mobilização da categoria e a eclosão de movimentos de solidariedade por parte de trabalhadores de outros setores produtivos demonstrou ao governo que os trabalhadores não acatariam passivamente o desmonte desenfreado proposto pelo modelo neoliberal. Isto fica claro pelo fato da Petrobrás ter sido uma das poucas empresas produtivas a não sofrerem processo de privatização, bem como pela edição da lei 9.689/98, que anistiou os sindicatos do montante ainda devido em decorrência das multas aplicadas pelo TST, e da lei 10.790/2003, que determinou a reintegração dos trabalhadores que sofreram punições, demissões ou suspensões por participarem do movimento grevista.

\section{3 - A greve dos trabalhadores em transporte de Campinas em 1998}

No dia 30 de março de 1998 os trabalhadores em transportes rodoviários de Campinas e região iniciaram uma importante greve. Note-se que aqui o adjetivo importante não foi utilizado tanto em relação ao seu resultado prático, já que os trabalhadores não lograram obter suas reivindicações. A importância desta greve se deve ao fato de ser um movimento atípico que possibilita um estudo da atuação punitiva do poder judiciário em relação às greves políticas.

Nesta greve, os trabalhadores interromperam a prestação de serviços repentinamente, sem qualquer deliberação sindical, para protestar contra a aprovação de um projeto de lei pela Câmara de Vereadores de Campinas, projeto de lei este que regularizava o transporte alternativo de passageiros, também conhecido como "perueiros". As suscitantes do presente dissídio coletivo pretendiam a declaração de ilegalidade e abusividade da greve, com imediato retorno ao trabalho e desconto dos dias parados. Esta declaração de ilegalidade e abusividade decorreria do fato de "se tratar de greve selvagem, porque decretada em atividade essencial" e também por ser uma greve política "pois não respaldada em reivindicação contra o empregador, mas em afronta ao Poder Público".

Segundo o sindicato dos trabalhadores, "tratou-se de uma manifestação repentina sem prévia deliberação, iniciando-se da metade para o final da votação sobre a aprovação da lei dos perueiros na Câmara Municipal, na noite do dia 30/03/98, quando comunicaram que os vereadores que haviam dado apoio à categoria mudaram seus votos, 
passando a votar a favor dos perueiros". A informação de que o prefeito vetaria uma emenda indicada pelo sindicato profissional que propunha a manutenção do número de linhas e carros "que, por via de consequência mantinha o emprego dos motoristas, cobradores e trabalhadores da categoria" só estimulou ainda mais a deflagração do conflito. Este sindicato esclareceu ainda que instruiu os trabalhadores sobre a importância de encerrar a greve, mas que em uma assembleia geral realizada ao meio-dia do dia seguinte "a categoria votou pela continuidade do movimento de protesto, mesmo estando ciente de que o sindicato era contrário". A greve terminou no final deste mesmo dia, após pressão sindical em nova assembleia geral.

Verifica-se que há duas questões centrais a serem analisadas neste dissídio coletivo: a legitimidade formal, decorrente da deflagração do movimento grevista de modo abrupto, e a legitimidade material, decorrente da finalidade eminentemente política da greve.

Em relação à legitimidade formal, o movimento paredista foi considerado abusivo ante a inexistência de tentativa de negociação prévia, ausência de convocação de assembleia geral pelo sindicato e deliberação coletiva sobre a paralisação, bem como pela greve ter ocorrido em serviço essencial sem a manutenção de serviços mínimos e sem comunicação com 72 horas de antecedência ${ }^{130}$.

A greve foi igualmente considerada abusiva em seu aspecto material. $\mathrm{Na}$ própria ementa do acórdão consta que "segundo o disposto no art. $1^{\circ}$ da Lei 7.783/89, compete aos trabalhadores decidir sobre os interesses que devam por meio da greve perseguir, existindo limitação somente no que diz respeito a objetivos estranhos à categoria profissional". Uma vez que a paralisação ocorreu como forma de pressão ao poder legislativo e executivo do município, não havia qualquer reivindicação que pudesse ser atendida pelo empregador. A consequência lógica das premissas apresentadas pelo voto é que a greve foi materialmente abusiva.

Contudo, ao analisarmos o caso concreto, verifica-se que não há que se falar em abusividade do movimento grevista tanto em relação à sua forma quanto ao seu conteúdo.

\footnotetext{
${ }^{130}$ Nos termos do acórdão: "Demonstrado, assim, que o movimento se deu sem a observância do disposto nos artigos $3^{\circ}, 4^{\circ}, 9^{\circ}, 10^{\circ}$, inciso V, 11 e 13 da Lei 7.783/89. Inobservados os requisitos da Lei 7.783/89, como ficou evidenciado acima, o exercício do direito de greve, formalmente, foi abusivo."
} 
Em relação à legitimidade formal do movimento paredista, esta deve ser analisada de acordo com a especificidade do caso sub judice. Trata-se de uma greve formalmente atípica, eis que ocorreu de forma espontânea pelos trabalhadores, em decorrência de uma alteração repentina no andamento da votação do projeto de lei.

Já foi analisada anteriormente a licitude das greves atípicas. No caso desta greve, a ausência de assembleia para deliberar sobre a paralisação foi suprida pela grande adesão de trabalhadores ao movimento. Ademais, a questão foi superada pela Assembleia Geral organizada no dia seguinte, na qual foi votada a continuidade do movimento pela categoria, o que demonstra que o movimento correspondeu aos anseios da coletividade.

Ante a particularidade do caso em questão, inexigível dos trabalhadores tanto a deliberação em assembleia quanto a necessidade de notificação prévia. Isto porque o movimento se originou em decorrência de alterações singulares no curso da votação do projeto de lei. A greve, neste caso, só teria sentido se fosse deflagrada naquele exato momento. O cego cumprimento destes requisitos implicaria na ineficácia do movimento grevista. Desta maneira, os requisitos devem ser interpretados à luz dos princípios que regem o Direito Social.

Não há também como alegar que a deflagração da greve surpreendeu o poder público. A votação do projeto de lei estava marcada e estava ele ciente de que o que seria deliberado traria importantes consequências para a relação laboral dos trabalhadores.

Nem mesmo a questão da manutenção do serviço mínimo às necessidades essenciais da coletividade pode ser invocada, eis que em nenhum momento do voto houve notícia de que a paralisação afetou este atendimento. Não há dados sobre a parcela de obreiros que cruzaram os braços nem da quantidade mínima necessária para assegurar a prestação dos serviços indispensáveis ao atendimento das necessidades inadiáveis da comunidade. Como expresso no acórdão SDC-00268/2004-7 prolatado pelo Tribunal Regional do Trabalho da $2^{\mathrm{a}}$ região, a ausência destes dados leva a crer que tais parâmetros foram atendidos pelos grevistas ${ }^{131}$. Trata-se de análise lógica, pois caberia à parte contrária provar suas alegações, in casu de que o movimento paredista não manteve o número mínimo necessário de trabalhadores. Verifica-se que embora a greve fosse atípica, desta atipicidade não decorreu nenhuma abusividade.

${ }^{131}$ Acórdão SDC-00268/2004-7, relativo ao Proc. 20321200400002001, TRT 2a região. Rel. Des. José Carlos Arouca. 
Já em relação à legitimidade material da greve, deve-se apontar que há no presente voto uma falha nas premissas utilizadas para embasar a decisão. Ao contrário do que apontou o relator, não há em qualquer texto legal uma limitação da greve "no que diz respeito a objetivos estranhos à categoria profissional". Ao contrário, tanto o texto constitucional quanto a legislação específica são claros ao estabelecer que competem aos trabalhadores decidir sobre os interesses que visam defender por meio de seu direito de greve.

Conforme já foi apontado no presente estudo, tampouco há que se falar que tal limitação decorre de interpretações sistemáticas ou principiológicas do texto legal. A greve não poderia ser considerada abusiva unicamente por possuir reivindicação política. Evidencia-se no presente acórdão, e que será confirmado nos julgados que ainda serão estudados, que embora não exista qualquer limitação legal à motivação política da greve, a jurisprudência de nossos tribunais continua a sustentar sua abusividade.

No presente processo, a limitação ocorreu unicamente porque "no caso dos autos, não existe qualquer reivindicação da categoria que possa ser atendida pelo empregador", tratando-se de "forma de pressão ao atendimento de reivindicações junto aos Poderes Legislativo e Executivo do Município".

Em que pese haver danos ao empregador e aborrecimentos à população, a simples motivação política da greve não representa qualquer desrespeito a garantias fundamentais. Ao declarar a ilegalidade da greve política o Tribunal abandona uma análise principiológica do direito de greve e limita o debate jurídico, restringindo indevidamente um direito dos trabalhadores.

A importância do estudo do presente caso se deve ao fato de que mesmo diante da complexidade das causas e do desenvolvimento deste movimento grevista, a solução dada pelo Tribunal Regional do Trabalho da $15^{\mathrm{a}}$ região no acórdão não abordou suas diversas problemáticas. É certo que é princípio do poder judiciário a prestação jurisdicional célere sobre os conflitos que lhe são apresentados. É certo também que uma decisão concisa e direta facilita esta prestação, eis que diminui o tempo que o magistrado leva para redigir seu voto e reduz a probabilidade de recursos. Entretanto, alguns casos merecem uma abordagem mais aprofundada e complexa por parte de nossos tribunais, seja em decorrência de sua importância paradigmática, seja pela complexidade dos eventos apresentados. É o caso do presente dissídio coletivo. 


\section{4 - A greve dos trabalhadores nas indústrias urbanas do Rio de Janeiro em 1998}

"A greve política não é um meio de ação direta da classe trabalhadora em benefício de seus interesses profissionais e, portanto, não está compreendida dentro do conceito de greve legal trabalhista". Desta maneira iniciam-se as ementas de dois acórdãos do TST, referentes ao processo TST-RODC-454136/98.7, proferido em 14 de junho de 1999, e ao processo TST-RODC-571212/99.0, proferido em 31 de agosto de 2000.

Trata-se de dois dissídios coletivos ajuizados pela Companhia Estadual de Águas e Esgotos - CEDAE em face do Sindicato dos Trabalhadores nas Indústrias Urbanas do Rio de Janeiro e do Sindicato dos Administradores no Estado do Rio de Janeiro, afirmando que as greves realizadas pelos suscitados foram abusivas.

O processo TST-RODC-454136/98.7 é relativo às greves que ocorreram nos dias 28 de janeiro e 3 de fevereiro de 1998, nas quais os trabalhadores da CEDAE paralisaram seus serviços para protestar contra o leilão de privatização da empresa. As paralisações ocorreram nos mesmos dias que foram realizadas audiências públicas relativas ao processo de privatização da empresa. O Tribunal Regional do Trabalho da $1^{\mathrm{a}}$ região declarou a abusividade da greve deflagrada com motivação política, decisão esta que foi mantida pelo TST. O processo TST-RODC-571212/99.0, relativo à greve de 8 de outubro de 1998, possui igual motivação e mesmo resultado jurídico.

Para justificar seu posicionamento no processo 454136/98.7, o Tribunal de origem apontou que:

A circunstância de confiar o caput do art. $9^{\circ}$ da Constituição Federal aos trabalhadores 'o direito de decidir sobre a conveniência e oportunidade' de exercer o direito de greve, não implica em considerar os obreiros únicos senhores do momento e dos motivos para a deflagração do movimento paredista. Não há direito absoluto, há limites que são impostos inclusive pelos direitos de terceiros, sendo certo que o direito deve ser exercido nos limites do justo e razoável."

(...) $\mathrm{O}$ art. $9^{\mathrm{a}}$ da Constituição Federal não deve levar a considerar-se os trabalhadores como os únicos árbitros para a deflagração e a motivação da greve, pois pensar que esses interesses podem ser de qualquer natureza - econômica, política, profissional, subversiva, etc. -, o que seria adotar método pouco ortodoxo da interpretação de uma Constituição. É claro, portanto, que esses conflitos não serão motivados por questões políticas. 
(...) Não é outro o nosso entendimento que tais greves pipocam, eis que não são por um período continuado, tem acentuado teor político, visando compelir o Estado a seguir caminho diverso do que pretende trilhar, dentro da legalidade. Há fundado receio que estes movimentos se repitam, daí porque há que se coibir a repetição. ${ }^{132}$

Igualmente em decisão do tribunal de origem, no processo 571212/99.0 foi proferida uma ementa que aponta que "a doutrina e a jurisprudência não admitem greves de cunho político, pelo que a paralisação ocorrida, em protesto contra o processo de privatização da Suscitante, caracteriza exercício abusivo do direito de greve, com todas as suas consequências legais" ${ }^{133}$.

Em ambos os casos, ao recorrer ordinariamente ao TST, pretendendo alteração das sentenças de origem que declararam as greves abusivas, o sindicato teve seus recursos julgados improcedentes. Nos dois acórdãos, proferiu o Tribunal recursal a mesma ementa, no seguinte teor:

GREVE. NATUREZA POLÍTICA. ABUSIVIDADE. A greve política não é um meio de ação direta da classe trabalhadora em benefício de seus interesses profissionais, e, portanto, não está compreendida dentro do conceito de greve trabalhista. Entende-se por greve política, em sentido amplo, a dirigida contra os poderes públicos para conseguir determinadas reivindicações não suscetíveis de negociação coletiva. Recurso Ordinário Obreiro parcialmente provido.

Segundo o TST "entende-se por greve política, em sentido amplo, a dirigida contra os poderes públicos para conseguir determinadas reivindicações não suscetíveis de negociação coletiva". O primeiro ponto a se questionar nesta afirmação do TST é o conceito de "reivindicações não suscetíveis de negociação coletiva". Como dito anteriormente, não podem ser os trabalhadores punidos pela imobilidade do poder público. No presente caso, a impossibilidade de negociação coletiva decorre da decisão unilateral de privatização da empresa. Contra tal decisão unilateral, o único meio de expressão que possuíam os trabalhadores era o exercício do direito de greve.

\footnotetext{
${ }^{132}$ Conforme citado pelo acórdão TST-RO-DC-454136/98.7, fl.03.

${ }^{133}$ Conforme citado pelo acórdão TST-RODC-571212/99.0, fl.04.
} 
Some-se a isso o fato de que ser dirigida contra os poderes públicos tampouco é critério para declarar ilegalidade da greve. No presente caso, os trabalhadores realizaram uma greve em que o poder público é tanto empregador quanto destinatário das reivindicações dos trabalhadores. Se greve contra decisões do governo é greve política, então todas as greves de servidores públicos o são. E como sabemos, a greve de servidores públicos é garantida na Carta Magna. A afirmação apresentada pelo TST só nos leva à conclusão de legalidade da greve política.

Ademais, em momento algum o TST apresenta os fundamentos legais para a separação entre "greve política" e de "greve legal trabalhista".

Quando tratamos juridicamente do conceito de greve, esta reflete o conceito exposto no artigo $9^{\circ}$ da Constituição Federal e no artigo $1^{\circ}$ da lei 7.783/89. Neste caso, o direito de greve é um conceito legal, eis que juridicamente definido por normas de natureza cogente. Trata-se de Direito Social constitucionalmente garantido e que, mesmo considerando a restritiva lei de greve, não encontra limitações em relação à sua finalidade. Ao excluir o conceito de greve política do âmbito das greves legais, o TST estabelece categorias que não aparecem em momento algum nas normas jurídicas.

Não há como contrapor os conceitos de greve trabalhista e greve política, eis que são adjetivações que decorrem de classificações distintas. A greve trabalhista é um gênero do fato social greve, assim como a greve de fome, a greve de contribuintes e a greve de consumidores. A greve é trabalhista por ser realizada por trabalhadores; são estes que adjetivam o conceito legal de greve, e não imposição doutrinária de motivação relacionada ao estrito contrato de trabalho. Já a greve política é uma espécie de greve, incorporada ao gênero "greve trabalhista", assim como a greve profissional e a greve econômica. Desta maneira, inexiste contradição entre "greve política" e "greve trabalhista" como sugere o TST e os autores por ele citados; não há nenhuma norma que aponte a separação entre greve política e greve trabalhista. Ao contrário, pode-se afirmar que "greve legal trabalhista" é um conceito redundante, eis que a greve, no sentido constitucionalmente exposto e dentro do âmbito do Direito do Trabalho, é um direito dos trabalhadores.

Ademais, a adjetivação "legal" ao conceito de "greve trabalhista", contrapondoa a greve política, já exclui, a priori e sem análise do caso concreto, a legalidade de todas as greves políticas. Esta interpretação do TST leva à conclusão de que a greve de trabalhadores não é um direito em si, mas apenas um conceito jurídico que pode vir a ser 
um direito caso a greve possua uma motivação diretamente relacionada ao estrito contrato de trabalho.

Contudo, a greve é um Direito Social fundamental e constitucionalmente garantido. A interpretação de direitos fundamentais deve ser realizada de forma ampliativa, em busca da promoção e ampliação destes direitos. Não há, reitere-se, nem na constituição nem na lei 7.783/89, qualquer referência que condicione a legalidade de greves ao seu conteúdo; ao contrário, possui expressa previsão nos dois textos de que compete aos trabalhadores decidir sobre os interesses que devam defender por meio do direito de greve.

A própria afirmação de que "a greve política não é um meio de ação direta da classe trabalhadora em benefício de seus interesses profissionais" aparece aqui de forma desconexa, quase que superficial, eis que não apresenta relação lógica com a matéria discutida. Ao afirmar que "a ilicitude se justifica, pois não se pode admitir uma desorganização na empresa, por reivindicações que não têm relação com ela e a que, por outra parte, não pode a empresa satisfazer", a decisão se afasta do caso concreto, onde os trabalhadores estão protestando contra o processo de privatização da empresa na qual trabalham. Evidente que este protesto tem relação direta com a empresa e que pode sim ser satisfeito por aqueles que a gerem. Esta greve tem também como finalidade demonstrar ao eventual sucessor privado que os empregados desta empresa estão mobilizados e não aceitarão alterações em seus contratos de trabalho.

Não está errada a afirmação de que se trata esta de uma greve política, eis que teve por objetivo pressionar o poder público para impedir a privatização da Companhia Estadual de Águas e Esgotos. Contudo, é evidente que a privatização de uma empresa afeta diretamente o contrato de trabalho de seus empregados. Aqui, mesmo a greve sendo política, guarda relação imediata com o contrato de trabalho, o que comprova na prática a falibilidade do argumento de que a greve política não age em benefício de interesses profissionais.

Desta maneira, evidencia-se o absurdo da ementa do presente acórdão. Ao afirmar que "a greve política não é um meio de ação direta da classe trabalhadora em benefício de seus interesses profissionais e, portanto, não está compreendida dentro do conceito de greve legal trabalhista", o acórdão baseia sua conclusão naquilo que pretende provar. Tautológico o raciocínio exposto na decisão, pois parte da premissa de que a greve política é ilegal para, ao final, provar a ilegalidade deste tipo de greve. 
Ambos os recursos encaminhados ao TST pelo Sindicato dos Trabalhadores nas Indústrias Urbanas do Rio de Janeiro foram julgados improcedentes em relação ao pedido de declaração de não-abusividade da greve.

\section{5 - As greves dos metroviários de São Paulo em 2006}

A solução dada à greve dos metroviários de 2006 pelo Tribunal Regional do Trabalho da $2^{a}$ região e, posteriormente, pelo TST, é um caso emblemático para o estudo da visão de nossos julgadores sobre a greve política.

Em 15 de gosto de 2006 os trabalhadores da Companhia do Metropolitano de São Paulo - METRÔ paralisaram suas atividades por 24 horas em protesto contra o descumprimento de uma decisão judicial por seu empregador. Referida decisão judicial determinou a suspensão do processo de licitação da futura Linha 4 - Amarela à iniciativa privada.

O Tribunal Regional do Trabalho da $2^{\mathrm{a}}$ região julgou a greve abusiva, proferindo a seguinte ementa:

ATIVIDADE ESSENCIAL. GREVE DOS METROVIÁRIOS. ABUSIVIDADE MATERIAL DO MOVIMENTO

O movimento de paralisação dos serviços qualificados no artigo $9 .^{\circ}$ da Constituição Federal tem de estar vinculado à reivindicação contida no contrato de trabalho. Esta é a materialidade necessária, para que se possa falar em greve.

Se a paralisação dos serviços ocorreu por motivação política, a "greve", por mais justa que possa parecer, deve ser considerada materialmente abusiva.

Por outro lado, o não atendimento à ordem judicial de manutenção mínima dos serviços configura também afronta ao sistema jurídico positivo, sustentáculo do Estado Democrático de Direito, impondo-se, por consequência, a aplicação da multa por descumprimento da liminar.

Greve que se julga abusiva (fls. 743).

Esta ementa apresenta elementos que merecem ser rebatidos. Primeiramente, afirma o relator que o uma greve não pode possuir uma reivindicação que não esteja vinculada diretamente com o contrato de trabalho de seus participantes. Duas 
incongruências surgem desta afirmação: o que é uma "reivindicação contida no contrato de trabalho", e qual é a justificativa para tal limitação.

O raciocínio exposto pelo TRT é de que a greve, para ser considerada legal, deve preencher requisitos formas e materiais. Expõe que os requisitos formais são aqueles relativos aos procedimentos legais para a deflagração de um movimento grevista. Já os requisitos materiais dizem respeito ao conteúdo das reivindicações É com base nos requisitos materiais que o Tribunal faz a distinção entre greve política e greve trabalhista. Embora seja um conceito muito utilizado pela doutrina e pela jurisprudência, não há qualquer suporte legal para determinar a ilegalidade de uma greve segundo seu aspecto material.

Mais uma vez temos que reiterar neste trabalho que o artigo $9^{\circ}$ da Constituição Federal determinou ser de competência dos trabalhadores fixar os objetivos a serem defendidos por meio de uma greve. Não há restrição de qualquer natureza a este respeito. Em relação ao requisito material, portanto, a única exigência para que este seja legalmente válido é a necessidade de uma reivindicação, independentemente de qual ela seja.

Para sustentar seu posicionamento, o TRT inicia seu voto com um chavão jurídico: "É entendimento pacificado que o direito de greve, previsto na Constituição Federal, não é absoluto". Ao fazer esta afirmação logo no início de sua fundamentação, o TRT busca a concordância do leitor para um posicionamento específico através de um posicionamento genérico, baseado em uma ideia recorrente no direito contemporâneo: a de que não há direito absoluto. Entretanto, ao estabelecer uma afirmação genérica e conseguir a concordância do leitor, busca o TRT sustentar uma limitação indevida. No presente caso, o que buscou o TRT com esta afirmação foi sustentar indevidamente a o raciocínio tautológico de que, uma vez que o direito de greve não é absoluto, a restrição de sua finalidade a conflitos decorrentes do contrato de trabalho é necessária para evitar que a greve seja um direito absoluto.

Contudo, se por um lado nenhum direito é absoluto, nem mesmo direitos fundamentais, sua restrição só pode ocorrer em decorrência de lei ou de conflito com outros direitos fundamentais. A ideia de que nenhum direito é absoluto não pode de maneira alguma servir de justificativa para defender uma limitação a priori de um direito.

Ainda segundo o TRT, "n]ão resta a menor dúvida, portanto, de que a greve deflagrada pelos metroviários teve como única motivação a defesa de posição política, 
adotada pelo sindicato profissional, contrária à adoção de Parceria Público-Privada para operação da Linha 04 do Metrô". Aqui surge a questão central em todos os casos judiciais de greve política: qual a justificativa jurídica para limitar o movimento grevista a reivindicações atreladas ao contrato de trabalho? Percebe-se que em nenhum momento o TRT aponta esta justificativa. Como vimos ao longo deste estudo, nenhuma das justificativas apresentadas pela doutrina ou pela jurisprudência se sustentam juridicamente. Assim como ocorre no presente caso, as decisões se sustentam em afirmações baseadas em [pré]conceitos que não foram juridicamente analisados.

Isto pode ser percebido com maior intensidade na sequencia do voto, onde é exposto: "Ocorre, todavia, que o direito de greve não pode ser utilizado como instrumento de manobra para a defesa de posições políticas ou ideológicas.” As palavras aqui demonstram o peso do pensamento dos julgadores. Ao identificar a greve em questão como "instrumento de manobra", o TRT busca deslegitimar não apenas os interesses que motivam a greve, mas a própria formação destes interesses. Supõe indevidamente o órgão julgador que esta greve não representa a vontade dos trabalhadores, mas sim a de alguns indivíduos que manipulam os interesses da coletividade. A greve não seria abusiva apenas por ser política, mas também por ser resultado de manipulação.

Este entendimento do Tribunal é extremamente temerário. Além de ser antijurídico, abre precedentes para uma limitação indevida do direito de greve. É antijurídico pois o interesse da coletividade é expresso com a própria deflagração do direito de greve. A análise da formação de vontade dos trabalhadores não é elemento para o reconhecimento da legalidade de um movimento paredista. Ao ocorrer a paragem dos obreiros, os interesses defendidos representam a vontade da coletividade e não de um grupo específico.

Ademais, este posicionamento também abre precedentes para uma limitação indevida do direito de greve. A deslegitimação de um movimento grevista através do questionamento acerca da formação dos interesses da coletividade possibilita uma discricionariedade insustentável por parte dos Tribunais. Sendo a formação de interesses uma questão puramente subjetiva, não há parâmetro algum para se fixar o que seria uma "greve legítima" ou um "instrumento de manobra". Todos os movimentos grevistas estariam condenados a se sujeitarem a um juízo abstrato de valoração por parte dos tribunais. 
Uma greve não pode nunca ser considerada um instrumento de manobra. Se os trabalhadores paralisaram o trabalho, isto significa adesão às reivindicações formuladas. A partir do momento em que não concordem mais com as reivindicações, os trabalhadores possuem a liberdade de manifestar seu posicionamento e abandonar a greve. $\mathrm{O}$ termo “instrumento de manobra" foi lamentavelmente mal utilizado pelo TRT.

Prosseguindo, apontou ainda o TRT que "o que não se pode admitir, em hipótese alguma, é que o sindicato, sob o frágil argumento de que uma ordem judicial fora descumprida, deflagre um movimento de paralisação, causando prejuízos irreparáveis à população paulistana já tão carente de transporte público de qualidade." Neste trecho, inverte o TRT a lógica da responsabilidade, apelando indevidamente para a ideia de interesse da coletividade. Não pode a carência de transporte público na cidade servir de motivação para sustentar a ilegalidade de uma greve dos trabalhadores do Metrô.

A responsabilidade pela construção e manutenção de transporte público é dos órgãos políticos, inclusive através da empresa do Metrô, que no presente caso é suscitante da ação. Absurda a afirmação que busca penalizar o réu pela má administração realizada pelo autor. Se há prejuízos irreparáveis à população paulistana, estes decorrem principalmente da má gerência de recursos em relação às políticas de transporte público. É justamente em nome de uma melhor gerência destes recursos que protestam os grevistas ao buscar o respeito à legalidade e moralidade. Verifica-se que o raciocínio desenvolvido pelo TRT encontra-se distorcido. O que apontou como critério contra o movimento grevista é, na verdade, mais um ponto a sustentar sua legitimidade.

Aponta ainda a decisão de origem que "o inconformismo do suscitado com a postura adotada pela Companhia do Metropolitano de São Paulo poderia ser objeto de manifestações as mais variadas, sem que houvesse a paralisação dos serviços essenciais à comunidade". Desta maneira, acaba por reconhecer o TRT que os trabalhadores tem razão em seu inconformismo em relação às atitudes tomadas pelo empregador que motivaram a deflagração da greve. Segundo o TRT, apenas não poderiam os trabalhadores ter utilizado o direito de greve para protestar, o que encerra em si um absurdo, eis que a greve é o instrumento maior dos trabalhadores em defesa de seus interesses. Contraditoriamente, o 
que disse o TRT é que os trabalhadores tem razão em seu inconformismo, mas não podem exercer seu legítimo direito, pois isto acarretaria danos à coletividade ${ }^{134}$.

Através deste raciocínio, o Tribunal Regional do Trabalho de São Paulo declarou a abusividade da greve dos metroviários em decorrência de sua motivação, o que autorizou a empresa a descontar os dias parados.

Ante a decisão desfavorável no acórdão do regional, o sindicato obreiro interpôs recurso para o Tribunal Superior do Trabalho, afirmando que a greve não teve conteúdo exclusivamente político e sustentando que, de qualquer maneira, a greve não pode ser limitada a questões de natureza trabalhista, ante a amplitude facultada aos trabalhadores para definir os interesses a defender por meio da greve, conforme artigo $9^{\circ}$ da Constituição Federal.

Apesar de o novo acórdão ter reduzido a pena imposta ao recorrente, manteve a decisão de origem a respeito da abusividade do movimento grevista, proferindo a seguinte ementa a este respeito:

\begin{abstract}
METROVIÁRIOS. GREVE. ABUSIVIDADE. É abusiva, diante do ordenamento constitucional e infraconstitucional vigente, a greve política insurrecional ou de simples retaliação, destituída de conteúdo profissional. Hipótese em que os metroviários de São Paulo deflagraram greve, por 24 (vinte e quatro horas), em protesto, alegando descumprimento por parte da Companhia do Metropolitano de São Paulo - METRÔ (suscitante) de ordem judicial liminar proferida em ação popular, de interesse pessoal de dirigentes sindicais, em que se teria determinado a suspensão do ato de abertura dos envelopes de propostas das empresas concorrentes em processo de licitação tendente à concessão para a iniciativa privada, por meio de Parceria Público Privada (PPP), da nova Linha 4 - Amarela. Abusividade da greve caracterizada quanto ao aspecto da motivação.
\end{abstract}

Com relação a esta decisão, cabe apontar primeiramente que o resumo dos pedidos do recurso do sindicato dos trabalhadores efetuado pelo TST em seu voto é útil para demonstrar que a separação entre greve com fins políticos e fins profissionais não possuiu uma delimitação clara:

\footnotetext{
${ }^{134}$ Seria o caso de pensar como seria a reação de nossos juristas se um tribunal desapropriasse um grande e ostensivo centro comercial em São Paulo sob o argumento de que, neste caso específico, o exercício do direito de propriedade estaria acarretando graves danos à coletividade. Arrisco imaginar que a reação seria bem diferente.
} 
Alega que a implantação da parceria público privada enseja o início de amplo processo de privatização do sistema metroviário de São Paulo, o que conduz ao aviltamento das condições de trabalho da categoria profissional, já que "a empresa que poderá operar a Linha 04, não estará obrigada a seguir os Acordos Coletivos celebrados pelo recorrente e recorrida" (fls. 776), tampouco as condições de trabalho já existentes. Assinala, a título de exemplo, que o mencionado edital "faculta à empresa vencedora do certame operar os trens daquela linha sem empregados. E o que é pior. Permite que as estações da Linha 04 sejam operadas por intermédio de um 01 (um) único trabalhador" (fls. 776). Nesse contexto, argumenta que a greve não teve caráter exclusivamente político, mas com ela se buscou o cumprimento de ordem judicial desrespeitada, "a defesa do patrimônio público, bem como a manutenção das atuais condições de trabalho dos metroviários de São Paulo".

Incontroverso que a paralisação foi motivada tanto em decorrência do descumprimento de liminar como contra a privatização da linha amarela do metrô. A questão central para o TST neste caso passa a ser se esta motivação é ou não política e desvinculada do contrato de trabalho e, em caso positivo, se o fato de ser uma greve puramente política a torna abusiva.

Sobre a admissibilidade da greve política, o TST adotou uma interpretação mais extensiva que o Tribunal de São Paulo. Segundo o TST, a Constituição Federal de 1988 conferiu ao direito de greve uma ampla atuação, inclusive "elevando-o à estatura de Direito Social fundamental dos trabalhadores". Cita ainda o TST que:

\footnotetext{
Infere-se do atual Texto Constitucional, cujo art. $9^{\circ}$ foi reproduzido no art. $1^{\circ}$ da Lei $n^{\circ} 7.783 / 89$, que a greve é permitida, inclusive nos serviços essenciais expressamente elencados em lei, e que cabe aos trabalhadores não somente o juízo de conveniência a respeito do exercício da greve (momento ou oportunidade) como a eles toca o direito de decidir "os interesses" que, por meio dela, serão objeto de defesa.
}

Em relação ao caráter político da greve, há uma aparente alteração de posicionamento, sobretudo quando comparamos esta decisão com a decisão de 1998, anteriormente estudada. Neste voto o TST reconhece a possibilidade legal de executar uma greve política ante a ausência de qualquer impedimento constitucional: 
De outro lado, observa-se que, ao contrário do sistema jurídico vigente no período anterior à promulgação da atual Constituição Federal, em que se chegou a proibir a greve política (Lei $\left.\mathrm{n}^{\circ} 4.330 / 1964\right)$, no atual texto constitucional e na Lei $\mathrm{n}^{\mathrm{o}} 7.783 / 1989$, em que se regulamentou o exercício do direito de greve, não há literal vedação à greve política.

Todavia, tem-se que a amplitude conferida ao direito de greve na legislação constitucional e infraconstitucional citada autoriza, em princípio, as greves mistas ou decorrentes de conflitos político-econômicos, dirigidas, por exemplo, contra a política econômica do governo (política de emprego), as greves políticosindicais (garantias de atuação sindical), as greves motivadas pela luta por reformas sociais (habitações adequadas, transportes coletivos suficientes, saúde eficiente, etc.), que, embora não sejam solucionáveis diretamente pelo empregador, dependendo de atos legislativos ou governamentais, detêm conteúdo profissional, repercutindo na vida e trabalho da coletividade dos empregados grevistas. O mesmo não ocorre, porém, em relação à greve política insurrecional ou de simples retaliação, destituída de qualquer conteúdo profissional. Nestas hipóteses, exsurge o caráter abusivo do exercício do direito de greve.

Contudo, como dito, a alteração é apenas aparente. Ao mesmo tempo em que reconhece a legalidade das greves políticas, o TST trata de limitar esta possibilidade. Ademais, a aparência de que o TST adotou um posicionamento mais progressista, admitindo de forma mais ampla a possibilidade de execução de uma greve política, não resiste à análise prática de sua aplicação. O que se verifica na prática é que o Tribunal alterou também sua forma de classificar os movimentos grevistas para que estes não se encaixem em seu novo e amplo conceito de greve legal. Esta alteração de posicionamento faz apenas com que a conclusão tomada seja ainda mais insustentável do que nos casos anteriores.

No presente caso, o TST julgou abusiva a greve por entender que a greve possui "caráter de simples retaliação", afirmando que o sindicato profissional não tem legitimidade para atuar coercitivamente contra o descumprimento de uma decisão judicial, bem como "transparece o desejo pessoal da liderança sindical".

Ao julgar desta maneira, o TST decide negando seu próprio raciocínio. Como apontou também o TST, aos trabalhadores “toca o direito de decidir 'os interesses' que, por meio dela, serão objeto de defesa". Não cabe ao judiciário dizer qual foi o interesse 
defendido pela greve. A afirmação de que "transparece o desejo pessoal" de parte dos obreiros é irrelevante para o deslinde da questão. O movimento foi deflagrado através de deliberação coletiva, contando com grande mobilização da categoria. A pauta da greve é uma questão objetiva e que diz respeito a toda a categoria. Eventuais questões subjetivas não influenciam na legalidade do movimento. Efetuar análises subjetivas da motivação da greve retira dos trabalhadores a possibilidade de decidir as finalidades do movimento, eis que estas poderiam sempre ser revistas e a posteriori pelo judiciário. A palavra final sobre a motivação da greve seria sempre do julgador e nunca dos grevistas, o que é evidentemente inconstitucional.

Ademais, a greve em questão de maneira alguma se encaixa no conceito de “simples retaliação, destituída de qualquer conteúdo profissional”. O conteúdo profissional é evidente, eis que caso aprovada a privatização da nova linha do Metrô, seus funcionários não integrariam a categoria dos grevistas. Isto representaria uma forma de enfraquecimento de seus futuros movimentos, eis que estes novos funcionários teriam tratamento jurídico diferenciado, reduzindo sua identificação como classe única com objetivos em comum. Além disso, seria um precedente a possibilitar novas atomizações da categoria quando da construção de futuras linhas do Metrô.

O que se verifica portanto é que não se trata de simples retaliação, mas sim de um movimento contra o descumprimento de uma ordem judicial visando à "manutenção das atuais condições de trabalho dos metroviários de São Paulo". Além de ser evidente o caráter profissional desta greve, o que já seria suficiente para refutar a decisão, o presente caso enquadra-se também no conceito apresentado pelo TST de "greves político-sindicais" ou ainda de "greves motivadas pela luta por reformas sociais".

Percebe-se assim que o TST buscou alterar seu posicionamento sobre o exercício da greve com finalidade política para adequar-se ao texto constitucional. Desta maneira, o TST se adéqua à evolução jurisprudencial de que são "constitucionalmente admissíveis todos os tipos de greve: greves reivindicatórias, greves de solidariedade, greves políticas, greves de protesto" ${ }^{135}$. Contudo, tratou também de manter sua tradição jurisprudencial de classificar greves políticas como abusivas. Para isto, apontou uma "pequena" exceção à possibilidade política da greve e tratou de enquadrar a greve sub judice nesta exceção. O que fez o TST portanto foi alterar seu entendimento para se abster

${ }^{135}$ Voto do Ministro Eros Grau no Mandado de Injunção 712-8 Pará. 
de um posicionamento questionável sobre a greve política, mas mantendo na prática as limitações do posicionamento anterior. Desta maneira, não se verifica mudança efetiva no posicionamento do TST sobre a greve política, mantendo-se a visão restritiva que imperou em casos anteriores.

Deve-se contudo ressaltar que no tocante à declaração de abusividade da greve foram vencidos os Ministros Mauricio Godinho Delgado, João Oreste Dalazen e Walmir Oliveira da Costa. Infelizmente não foram juntados ao acórdão os votos divergentes ${ }^{136}$. O acesso a esses posicionamentos seria muito importante, pois demonstrariam as divergências existentes no próprio TST a respeito da legalidade de uma greve política, o que poderia influenciar juristas a se posicionarem mais criticamente contra a interpretação dominante.

\section{6 - A greve dos metroviários de São Paulo em 2007}

O acórdão 00127/2008-8, proferido pela seção de dissídios coletivos do Tribunal regional do Trabalho da $2^{\mathrm{a}}$ região no processo 20218003020075020000, apesar de não ser favorável aos grevistas, é de grande importância por demonstrar a existência de uma divergência entre os desembargadores em relação à finalidade das greves.

Trata-se de uma greve promovida pelo Sindicato dos Trabalhadores em Empresas de Transporte Metroviário de São Paulo que, no dia 23 de abril de 2007, suspendeu parcialmente as atividades do Metrô de São Paulo como meio de pressão e protesto contra a articulação existente à época no Congresso Nacional para derrubar o veto presidencial da Emenda n. ${ }^{\circ}$ 3, apelidada de "Super Receita".

Antes do início da greve, foi ajuizada uma medida cautelar pelo Metrô de São Paulo, na qual foi deferida uma limitação em relação à quantidade de trabalhadores que poderiam se abster de trabalhar em decorrência da necessidade de manutenção dos serviços essenciais $^{137}$. Posteriormente foi movido um Dissídio Coletivo de Greve pelo Ministério

\footnotetext{
${ }^{136}$ Apesar da interposição de Embargos de Declaração por parte do sindicato dos trabalhadores alegando omissão e pleiteando a juntada de tais votos divergentes, o relator afirmou inexistir omissão, eis que "a juntada de voto vencido para conhecimento da tese divergente constitui faculdade do magistrado vencido, (...) situação que não ocorreu no caso concreto" e que "não cabe ao magistrado vencedor, quer por dever legal, quer por ausência de convicção, registrar a tese vencida". 
Público do Trabalho ${ }^{138}$, postulando indenização pela não manutenção de serviços essenciais durante o dia da paralisação.

A pretensão dos trabalhadores justificava-se na preocupação da possível derrubada do veto presidencial à Emenda n. ${ }^{\text {o } 3, ~ o ~ q u e, ~ c a s o ~ o c o r r e s s e, ~ i m p o s s i b i l i t a r i a ~ o s ~}$ auditores fiscais do Ministério do Trabalho de intervirem nas relações das empresas com os prestadores de serviços. Este enfraquecimento da fiscalização facilitaria, por exemplo, a contratação de funcionários como "prestadores de serviços" através de pessoas jurídicas abertas por exigência patronal ou mesmo através de falsas cooperativas de trabalho.

Verifica-se portanto que a greve teve como único objetivo pressionar o Congresso a não derrubar o veto presidencial relacionado a uma Emenda. Não havia uma reivindicação ligada ao "estrito contrato de trabalho" que pudesse ser negociada e cumprida pelo empregador. Sem dúvida tratou-se de uma greve política.

Ao mesmo tempo em que a greve possui tal conotação política, é evidente que possui também uma relação mediata com a relação de trabalho dos grevistas, pois é evidente que normas que enfraquecem a aplicação de garantias trabalhistas geram malefícios a longo prazo a todos os trabalhadores. Facilitar a contratação precária de trabalhadores coloca em risco a manutenção de empregos e fragiliza os direitos sociais historicamente adquiridos e legalmente garantidos.

Verifica-se que, no presente processo, a motivação da greve é considerada legítima tanto pelo Ministério Público do Trabalho, suscitante do processo, quanto pelos julgadores do Tribunal Regional do Trabalho da $2^{\mathrm{a}}$ região.

Segundo o Ministério Público:

O conteúdo do protesto, comum aos motoristas e metroviários, não é político, como alardeiam alguns, no sentido de estar vinculado a qualquer política partidária, mas é manifestamente legítima das categorias profissionais, em face da mencionada Emenda $n^{\circ} 3$, esta sim, contrária às garantias constitucionais e legais outorgadas a todos os trabalhadores e aos seus mais legítimos interesses. $\mathrm{O}$ art. $9^{\circ}$ da Constituição Federal assegura o direito de greve, deixando claro que compete 'aos trabalhadores decidir sobre a oportunidade de exercê-lo e sobre os interesses que devam por meio dele defender'.

${ }^{138}$ Processo TRT/SP No 20218.2007.000.02.00-4 
Ora, compete aos trabalhadores decidir quais serão os interesses que devem defender por meio da greve, não havendo limitações impostas pela Carta Constitucional no sentido destes interesses estarem imediatamente ligados aos contratos de trabalho e às especificidades de cada categoria profissional. É cabível, a nosso ver a defesa de interesses imediatos, pertencentes, inclusive, ao trabalhador em geral.

Importante verificar a ressalva feita pelo MPT ao conceituar a greve política. Segundo a delimitação feita pelo parquet, a greve política seria somente aquela que possui um conteúdo "no sentido de estar vinculado a qualquer política partidária". Nesta conceituação, a greve política seria somente aquela que assumisse um caráter nitidamente partidário, em dissonância com a vontade geral da categoria de trabalhadores. Entretanto, esta conceituação dada pelo MPT deve ser analisada com cautela.

Ao contrapor greves políticas e greves legítimas, o MPT confirma a tese dominante de que greves políticas são substancialmente ilegais. O MPT utilizou um conceito extremamente restrito de "greve política", possibilitando assim uma maior atuação dos trabalhadores com o movimento grevista. Em que pese o benefício desta interpretação ao caso sub judice, admitir a ilegalidade da greve política é filiar-se, ainda que parcialmente, à doutrina restritiva, que não enxerga nos trabalhadores um grupo social apto a exercer coletivamente seus interesses de classe na democracia. Não há qualquer suporte normativo para defender a limitação de uma greve por possuir conteúdo político.

A desembargadora relatora Anelia Li Chum também admitiu a legalidade da greve dos metroviários em relação aos objetivos almejados pela categoria. Segundo a relatora deste processo:

Com efeito, o protesto manifestado pelos obreiros representados pelo Requerido volta-se contra uma possível derrubada do veto presidencial, pelo Congresso Nacional, da Emenda ${ }^{\text {o }}$ 3, conhecida como Emenda da "Super Receita", que coíbe os auditores fiscais do Ministério do Trabalho de atuarem frente a irregularidades verificadas na contratação de trabalhadores.

É certo que o conteúdo de referido protesto é legítimo das categorias profissionais como um todo, e, portanto, também dos trabalhadores que prestam serviços ao Metrô. É certo, ainda, que o caput do artigo $9^{\circ}$ da Constituição da República assegura o direito de greve, deixando claro competir "aos 
trabalhadores decidir sobre a oportunidade de exercê-lo e sobre os interesses que devam por meio dele defender".

Contudo, verifica-se no acórdão do TRT que esta decisão não foi unânime. Os desembargadores Sonia Maria Prince Franzini, Catia Lungov e Nelson Nazar, votaram pela abusividade do movimento grevista por entenderem ser a greve política, mas foram vencidos pelos demais desembargadores, que se filiaram ao entendimento da desembargadora relatora.

Por outro lado, em que pese não haver neste acórdão limitação à legitimidade de uma greve a demandas restritas ao contrato de trabalho, a solução dada a este processo não demonstra o mesmo respeito ao exercício do direito de greve no que se refere à manutenção do movimento grevista. Sob a justificativa de tratar-se de serviço essencial à população, nos termos do artigo $9^{\circ}, \S 1^{\circ}$ da Constituição, foi concedida liminar na ação cautelar determinando aos funcionários a manutenção de $100 \%$ da operação das linhas do metrô nos horários de pico (entre 06:00h e 09:00h e entre 16:00h e 19:00h) e 80\% nos demais horários.

Impossível afirmar que o direito de greve foi respeitado quando há $100 \%$ dos funcionários trabalhando na empresa em decorrência de ordem judicial. A definição mais básica de greve, que sequer é contestada por qualquer doutrina e que decorre do texto do artigo $2^{\circ}$ da lei 7.783/89, é que esta é a suspensão coletiva de prestação pessoal de serviços a empregador. Ao obrigar a manutenção de $100 \%$ dos trabalhadores, os desembargadores do Tribunal Regional do Trabalho da $2^{\mathrm{a}}$ região não estão simplesmente enfraquecendo o movimento grevista, mas sim negando aos trabalhadores o exercício de um direito constitucionalmente garantido.

Para justificar esta restrição, desembargadora relatora apontou que:

(...) não se trata, in casu, de inviabilizar por completo o exercício do direito de greve, mas, apenas, de condicionar tal exercício ao atendimento das "necessidades inadiáveis da comunidade", as quais são mencionadas, de forma expressa, pela própria Lex Fundamentalis (art. $9^{\circ}, \S 1^{\circ}, \mathrm{CF} / 88$ ). Também é a própria Constituição da República (art. $9^{\circ}, \S 1^{\circ}, \mathrm{CF} / 88$ ) que remete à lei infraconstitucional de regência (no caso, a Lei $n^{\circ} 7.783 / 89$ ) a definição do que sejam "serviços ou atividades essenciais" Os documentos acostados aos autos endossam a conclusão da D. Procuradoria Regional do Trabalho, no sentido de 
ser "indiscutível que a não manutenção de um percentual mínimo de funcionários deixará a população em geral totalmente desatendida".

Entretanto, verifica-se que não houve a fixação de um "percentual mínimo de funcionários" nos horários de pico, mas sim o impedimento do exercício do direito de greve em tais períodos.

Se a limitação do direito de greve não ocorreu em relação à finalidade pretendida pelo movimento, como se deu nos demais dissídios já estudados, no presente caso o caráter político da greve transparece através da proibição da paralisação dos trabalhadores sob o argumento de garantir serviço essencial. Procurando se afastar da análise do caráter político da greve, a restrição foi alternativamente deslocada para a discricionariedade legal relativa à manutenção de serviços essenciais. Assim, pretendeu-se esconder o caráter político desta decisão sob a cortina da normatividade jurídica ${ }^{139}$.

A determinação legal de assegurar a prestação de serviço essencial não pode ser interpretada de modo a impedir a paralisação dos trabalhadores. A fixação destes parâmetros pelo judiciário enfraquece o poder de negociação do movimento grevista, reduzindo a pressão exercida e prolongando a situação litigiosa.

A fixação de parâmetros extremamente rígidos também é um fator que contribui para seu descumprimento, ainda mais se tratando de movimento coletivo que muitas vezes escapa do controle do próprio sindicato. Como explicar, por exemplo, para uma categoria que está em greve com mais de $40 \%$ de adesões, que todos os trabalhadores deverão trabalhar normalmente no dia da greve? Como convencer o trabalhador de que, ao trabalhar como se não estivesse em greve, ele estará exercendo uma pressão em prol de suas reivindicações? Como obrigar o trabalhador a agir da mesma maneira que um furagreve?

O artigo 11 da Lei 7.783/89, que serve de suporte para a fixação destas restrições, foi interpretado de maneira extremamente prejudicial aos trabalhadores. Este artigo incumbe igualmente aos sindicatos, aos trabalhadores e aos empregadores a responsabilidade para manter os serviços essenciais. A decisão do Tribunal paulista fez imposições somente aos trabalhadores e ao seu sindicato, em nada responsabilizando a empresa. Através de seu poder normativo, poderia a Justiça do Trabalho fixar soluções que

${ }^{139}$ Como se essa normatividade não fosse, ela também, política. 
mantenham o equilíbrio em relação à parcela de responsabilidade de cada envolvido. Poderia, por exemplo, determinar que os trabalhadores que forem obrigados a trabalhar durante a greve receberão as horas com adicional de horas extras. Ou ainda que fossem convocados apenas os funcionários responsáveis pelo funcionamento técnico e operações, ficando desobrigados de trabalhar os funcionários responsáveis pelo controle de catracas e venda de bilhetes, possibilitando o livre acesso de usuários. São diversas as saídas que poderiam ser encontradas para distribuir equanimente as responsabilidades elencadas no artigo em questão.

Em decorrência desta interpretação, o Tribunal Regional do Trabalho aplicou ao Sindicato dos Trabalhadores em Empresas de Transporte Metroviário de São Paulo uma multa no importe de cinquenta mil reais ${ }^{140}$.

Contudo, em grande parte pelo caráter repressivo da decisão judicial, o conflito entre as partes não foi solucionado. Pouco tempo depois, o Metrô de São Paulo realizou demissões e afastamentos para apuração de falta grave "por atos que teriam sido praticados durante a paralisação ocorrida nas primeiras horas do dia 23 de abril de 2007"141.

Em resposta os trabalhadores deliberaram um calendário de greves em solidariedade aos colegas punidos. Esta ameaça de paralisação gerou um novo dissídio coletivo: o processo SDC No 20253.2007.000.02.00-3.

Apesar da deliberação coletiva de paralisação geral garantir a readmissão dos cinco empregados demitidos, as partes celebraram acordo no qual o sindicato dos trabalhadores concordou em suspender a greve. Contudo, o sindicato suscitado "ressalvou a sua disposição de incluir na pauta de reivindicações (...) a revogação das punições impostas aos nominados empregados"142.

Mesmo com a perda do objeto do dissídio coletivo, a desembargadora relatora fez questão de salientar sua posição em relação ao mérito:

\footnotetext{
${ }^{140}$ Convém apontar que no dispositivo do acórdão a desembargadora relatora fez constar sua divergência em relação ao montante da multa a ser aplicada: "Neste ponto, revendo meu posicionamento em face da manifestação da maioria do Colegiado, hei por bem aplicar a multa arbitrada de $R \$ 50.000,00$ (montante superior àquele de $R \$ 25.000,00$ por mim originariamente propugnado para as duas demandas conjuntamente).

${ }^{141}$ Processo TRT/SP SDC N 20253.2007.000.02.00-3, Relatora Maria Aparecida Pellegrini.

${ }^{142}$ Foram os trabalhadores Paulo Pasin, Pedro Augustinelli Filho, Ronaldo de Oliveira Campos, Alex Fernandes Alcazar e Ciro Moraes.
} 


\begin{abstract}
A questão de fundo diz respeito a interesses individuais de um grupo de cinco empregados. Ressalte-se, por oportuno, que a ação intentada em sede de Dissídio Coletivo Econômico se presta a criar normas de trabalho de caráter geral e abstrato para a categoria, e o julgamento do Dissídio Coletivo de Greve objetiva pacificar eventuais divergências e impelir ao cumprimento de referidas normas, aplicáveis às empresas e seus funcionários durante a vigência do contrato de trabalho.
\end{abstract}

Para a relatora seria inadmissível a deflagração de movimentos grevistas de solidariedade, argumentando que não pode haver mobilização coletiva em prol de interesses individuais. Adotando este posicionamento, deixa a magistrada de atentar para questões imprescindíveis.

Primeiramente, como já exaustivamente apontado neste trabalho - mas repetição necessária ante a profusão de violações - cabe aos trabalhadores decidir pelos interesses que visam defender com a greve. Esta amplitude abarca inclusive a defesa de interesses individuais, se assim se predispor a coletividade, sem qualquer limitação.

Some-se a isso o fato de que uma greve de solidariedade como esta é um dos mais ricos exemplos de organização coletiva em prol do desenvolvimento da consciência coletiva dos trabalhadores.

No presente caso, o que os trabalhadores defendem não é apenas a reintegração do Sr. Pasin ou do Sr. Alcazar como ato de expressão individual. Aqui os trabalhadores demitidos assumem a forma da coletividade, eis que perseguições a trabalhadores que participaram do movimento grevista são atos que dizem respeito não só ao individuo que perde seu trabalho, mas também a todos aqueles que participaram do movimento, que são coagidos por estas demissões, tomando-as como ameaças a futuras mobilizações. A mensagem que fica é: se nesta greve foram demitidos estes cinco, na próxima poderei ser eu. Assim, a paralisação para defender a reintegração destes funcionários demitidos ultrapassa o caráter individualista apontado pela relatora e assume caráter de interesse da coletividade.

Mesmo com a extinção sem resolução do mérito do presente dissídio coletivo, o conflito entre as partes se manteve. Após diversas negociações com o governo, três empregados foram reintegrados, à exceção de Paulo Pasin e Alex Fernandez Alcazar. Contudo ambos foram reintegrados por decisão judicial. No dia 21 de agosto de 2008, o 
Metrô foi obrigado a reintegrar Pazin, o último dos grevistas que ainda continuava afastado, conforme decisão proferida pela $15^{\mathrm{a}}$ Vara do Trabalho de São Paulo.

A reintegração de todos os funcionários teve confirmou que as demissões realizadas pelo Metrô foram fruto de perseguição para desmobilizar uma categoria combativa. E esta perseguição só contribuiu para desenvolver o sentimento coletivo e reforçar a solidariedade entre os trabalhadores da categoria.

\section{7 - A greve dos trabalhadores e estudantes da Pontifícia Universidade Católica de} São Paulo em 2012

O mais recente caso de greve política de grande repercussão ocorreu na Pontifícia Universidade Católica de São Paulo durante o segundo semestre de 2012.

A PUC-SP é um dos grandes centros de excelência de ensino superior do Brasil e, embora seja uma instituição privada, possui uma ampla tradição democrática na formação de sua estrutura burocrática. Para a escolha do reitor, há a formação de uma lista tríplice pela Comunidade Acadêmica através de votação livre. Desde 1980, quando o Cardeal Dom Evaristo Arns assumiu o compromisso público de nomear para o cargo de reitor o candidato vencedor do pleito, o reitor da universidade é eleito pelo voto majoritário da Comunidade Acadêmica.

Entretanto, na eleição de 2012 o Grão Chanceler da Fundação São Paulo, ignorando o compromisso firmado há 32 anos, nomeou como reitora a candidata Ana Cintra, que obteve o menor número de votos entre os três candidatos à reitoria.

Em protesto por entenderem se tratar de uma arbitrariedade, os estudantes da PUC paralisaram suas atividades estudantis, não comparecendo às aulas, não assinando listas de presença e não realizando provas. Ao invés disso, os estudantes organizaram uma série de debates e palestras para discutir a crise instalada na Universidade.

Participam do presente dissídio coletivo o Sindicato dos Professores de São Paulo, que representa os professores da Universidade, primeiro suscitado, e o Sindicato dos Auxiliares de Administração Escolar de São Paulo, segundo suscitado, entidade que representa os demais funcionários.

Em 14 de novembro de 2012 os funcionários deliberaram pela realização de greve, "reivindicando a observância do resultado da democrática eleição realizada". 
Contudo, apesar da deliberação, foi constatado que apenas 15 a 20 trabalhadores paralisaram o trabalho, sendo que os demais optaram por esperar manifestação de Ana Cintra acerca de sua nomeação, eis que em debate realizado durante as eleições a mesma se comprometeu a não assumir o cargo caso não ficasse em primeiro lugar.

Já o sindicato dos professores afirmou inexistir movimento grevista, apenas a impossibilidade de ministrar aulas em decorrência da paralisação estudantil, mas salientando que os professores apoiavam a ação dos estudantes.

A primeira observação a ser feita em relação ao acórdão diz respeito à alegação de incompetência da justiça do trabalho apontada pelo ministério público. Por entender não se tratar de greve típica, eis que se trata de movimento de protesto contra decisão política, o ministério público apontou preliminar de incompetência da justiça trabalhista.

Esta preliminar foi prontamente rejeitada, afirmando o relator que "qualquer adjetivação que se dê à greve, seja típica ou atípica, abusiva ou não, é questão de mérito" e que segundo o artigo 114 da Constituição "o direito de greve é inerente às relações coletivas de trabalho".

Há aqui a reiteração da delimitação metodológica do direito de greve previamente apontada no presente estudo. A greve é um direito afeto à esfera trabalhista, e somente sob sua ótica principiológica pode ser este direito analisado. O fato de estar expresso na Constituição somente reforça sua supremacia hierárquica sob a ótica da evolução histórica da positivação dos direitos sociais. Reafirma-se neste voto a esfera dogmática à qual pertence o direito de greve, com sua historicidade, especificidade e metodologia; aplicações de lógicas advindas do direito civil, como lógicas contratualistas, são inaplicáveis a este direito.

Em seu voto, o relator examinou os aspectos formais que poderiam levar à abusividade do movimento paredista, dividindo-os em seis critérios: tentativa de negociação coletiva, deliberação sobre a paralisação coletiva, aviso prévio ao empregador, movimento pacífico, prestação de serviços indispensáveis e manutenção de movimento após celebração de acordo ou convenção coletiva.

Com relação à tentativa de negociação prévia, o relator inova a jurisprudência afirmando que "como se trata de greve política, na qual não se tem nenhuma conotação econômica, não se poderia exigir o requisito da exaustão da negociação coletiva". 
Ao entender que a greve não poderia ser declarada abusiva com relação à ausência de eventual negociação em decorrência da "peculiaridade do movimento grevista”, o relator assegurou a eficácia do direito de greve. Como visto em capítulo anterior deste trabalho, a greve não pode ser vista como abusiva em decorrência de ausência de negociações, sobretudo se este requisito é impossibilitado por aquele contra quem a greve se dirige.

No presente caso o movimento protesta contra a escolha da candidata menos votada para a reitoria da Universidade. A atitude discricionária do empregador impede qualquer possibilidade de conciliação, eis que a Universidade está ciente das exigências da comunidade acadêmica (empossamento do candidato mais votado ao cargo de reitor). A questão não é apenas da luta para empossar este ou aquele candidato, mas sim para garantir a eficácia de um sistema efetivamente democrático dentro de uma das mais importantes universidades do país. Transigir a respeito desta motivação seria deslegitimar o próprio movimento, eis que se admitiria a possibilidade de reconhecimento da quebra da tradição democrática em face de algumas compensações.

Ao relativizar a aplicabilidade deste requisito no caso sub judice, o magistrado assegurou a eficácia do direito de greve no caso concreto, respeitando os princípios norteadores do Direito do Trabalho. Não se trata aqui de desrespeito à norma legal como pensarão alguns, mas ao contrário, trata-se de pleno acolhimento do ordenamento jurídico trabalhista, eis que a decisão abordou de forma coerente as particularidades do movimento grevista em vista da construção principiológica específica do ordenamento trabalhista. Não há negação do direito, como ocorreu, por exemplo, no voto do ministro Armando de Brito no caso da greve dos petroleiros de 1995, mas sim há efetivação do direito no caso concreto.

Esta coerência lógica é mantida na análise da necessidade de deliberação sobre a paralisação coletiva. Segundo o relator, "pelas particularidades do movimento grevista, não se pode exigir tamanho formalismo".

No presente caso, apesar do primeiro suscitado não ter realizado uma assembléia pela própria entidade sindical, o magistrado apontou que há "convicção de que a greve é um ato refletido e consensual, ou seja, uma ponderação coletiva e como forma de repulsa ao critério de escolha do reitor". 
Como visto anteriormente quando abordamos a questão da atipicidade das greves, a necessidade de deliberação não pode ser tratada como critério para limitar o direito de greve, mas apenas para garantir a eficácia de um movimento grevista.

Assim, independentemente da realização formal de uma assembléia pelo sindicato, através da organização do movimento é possível verificar que se trata de vontade representativo da vontade geral dos trabalhadores em prol de um objetivo comum. A atipicidade do movimento só reforça a superação deste requisito. Nas assembléias se discute a pauta de reivindicações trabalhistas, como valores, horários, condições específicas de trabalho, com o objetivo de formar uma pauta reivindicatória uniforme que seja condizente com os anseios dos trabalhadores. No presente caso, se trata de uma greve política com uma finalidade única e específica: garantir a efetividade democrática da eleição para a reitoria da Universidade.

Neste sentido, conclui o relator a respeito da necessidade de deliberação prévia que "esta greve não se reputa um movimento grevista típico. Como não foram extraídas reivindicações de natureza trabalhista, entendo que a realização da assembléia não pode ser exigida dos trabalhadores".

Tampouco julgou o relator ser a greve abusiva em decorrência do fato do primeiro suscitado não ter efetuado o aviso prévio para fins de greve previsto no parágrafo único do artigo $3^{\circ}$ da Lei 7.783/89. Isto porque "é inegável que a empresa tinha plena ciência da greve, em especial, pelo desenvolvimento natural e do motivo que levou à greve".

A necessidade de aviso prévio visa garantir que o empregador tome ciência do movimento grevista e suas reivindicações de modo a possibilitar um diálogo conciliatório e reorganizar sua empresa durante a paralisação. Assim, este requisito é inaplicável quando o empregador está ciente que as decisões que toma são de tal forma controversas e abruptas que podem gerar um sentimento de revolta no seio da coletividade de trabalhadores.

O empregador calcula os riscos inerentes às suas escolhas e sabe que uma greve pode ocorrer como resposta, mas decide assumir o risco em nome de eventual benefício empresarial - no presente caso, o desrespeito a uma tradição democrática em nome da nomeação de uma candidata que ficou em último lugar na votação.

Assim como ocorreu na greve dos trabalhadores em transportes rodoviários de Campinas em 1998, impossível ao empregador alegar que se trata de ato repentino e que 
foi surpreendido pela deflagração do movimento. Contudo, ao contrário do que foi decidido no caso de 1998, no qual o relator desrespeitou a estruturação principiológica do Direito do Trabalho ao fazer uma interpretação restritiva da lei, no presente dissídio o relator assegurou a eficácia do direito fundamental de greve afirmando que no presente caso "este aspecto não pode ser invocado como motivo a justificar a caracterização da greve como abusiva".

Quanto ao critério do exercício pacífico do exercício do direito de greve, afirmou o magistrado que "a greve é pacífica e dentro dos limites da normalidade". Mais adiante em seu voto, o relator expõe que "a reação foi equivalente ao ato da instituição".

Apresenta o relator uma concepção inovadora na jurisprudência pátria relativa ao direito de greve. Embora o princípio da proporcionalidade seja amplamente utilizado em outras matérias jurídicas, quando se trata do direito de greve ele é sumariamente ignorado. O conceito de "exercício pacífico" do direito de greve não pode ser analisado in abstrato, como se a ideia de paz fosse matematicamente mensurável. O exercício do direito de greve deve ser analisado com base na conjuntura que o originou. Não há como se exigir dos grevistas que respondam com o "exercício pacífico" abstrato a uma violência do empregador. Eventuais atos que isoladamente possam ser vistos como violentos, ao serem contextualizados na realidade que os originou podem ser tidos como reação legítima e proporcional a um ato violento perpetrado pelo empregador.

A greve não é o conflito, mas sim sua externalização; o conflito preexiste à deflagração da greve. Assim, eventual animosidade da greve pode representar apenas um externalização proporcional a um conflito violento originado pelo próprio empregador.

Desta maneira, a ideia de "reação equivalente" exposta pelo magistrado é juridicamente impecável, eis que respeita a particularidade do movimento grevista em face do ato que motivou sua origem.

Quanto à questão da prestação de serviços indispensáveis ao atendimento das necessidades inadiáveis da comunidade, desnecessária sua análise pormenorizada, eis que inaplicável à empresa em decorrência do caráter de seu objetivo social. Igualmente desnecessária o estudo da impossibilidade de manutenção do movimento paredista quando haja acordo, convenção ou decisão da Justiça do Trabalho, eis que o motivo da paralisação não foi tratado em nenhuma das hipóteses elencadas.

Assim, a greve foi declarada não abusiva em seu aspecto formal. 
O suscitante alega também em sua inicial que a greve é materialmente abusiva por se tratar de greve política, sustentando que o ordenamento pátrio só admite movimentos de cunho estritamente profissional.

Ao abordar esta questão, o relator esclarece que "é inegável que o direito de greve não se resume tão somente como fator de pressão objetivando a melhoria econômica. Portanto, é possível a eclosão das denominadas greves de solidariedade ou as greves políticas".

Ainda segundo o magistrado, a reação dos trabalhadores é plenamente coerente, eis que "foi quebrada uma regra tradicional da instituição quanto à escolha do novo reitor" e que, ciente de seus atos, a suscitante "deveria ter a consciência de que haveria uma repulsa natural por parte desta própria comunidade"; assim, o movimento grevista foi uma reação "equivalente ao ato da instituição".

Abrindo as portas para uma nova jurisprudência, o relator expressa que "a greve é política" e decreta a não abusividade do movimento.

Como conclusão a este processo, apesar de decretar a não abusividade do movimento, o relator determinou que, ante o término da paralisação dos funcionários e da existência de recursos administrativos e judiciais a respeito da escolha do reitor, deveriam os professores encerrar a greve e esperar pelos desdobramentos administrativos existentes. Este aspecto da decisão foi completamente inócuo, eis que os professores encerraram a paralisação em 12 de dezembro de 2012, antes da publicação do acórdão em 16 de janeiro de 2013.

Este julgado representa um excelente contraponto àquele proferido pelo TST no caso dos petroleiros em 1995. Se com a greve de 1995 o direito de greve tal como assegurado pela nova constituição foi posto ao crivo do judiciário pela primeira vez, somente nos últimos anos, e em especial com a decisão no caso da PUC São Paulo de 2012, que podemos verificar uma maior efetivação do direito de greve. 


\section{CONCLUSÃO}

Por meio desta dissertação buscamos contestar os sentidos impostos à greve política pela jurisprudência. Seguimos a ideia de Edelman de que "era preciso lançar mãos ao trabalho de decifrar os julgamentos e as sentenças; era necessário tomar a sério as categorias jurídicas, os raciocínios aberrantes dos juristas, as fórmulas técnicas dos tribunais, o falso rigor da Doutrina" $" 143$.

E assim o fizemos. Tomamos a sério as categorias jurídicas relativas à greve política. Após fixarmos as bases metodológicas deste trabalho e analisarmos a historicidade da legislação relativa à greve, estabelecemos um coerente parâmetro para o desenvolvimento do estudo.

Tais "raciocínios aberrantes dos juristas" foram expostos à crítica ao longo dos capítulos intermediários. Neles apresentamos uma análise aprofundada do tema e apontamos as tensões existentes nas teses restritivas do direito de greve política, demonstrando inclusive a ausência de um sustentável respaldo legal.

Apontamos também o "falso rigor da doutrina" através do caráter tendencioso e economicista dos argumentos que permeiam a visão restritiva da greve, que indevidamente negam a aplicabilidade das normas trabalhistas e de seus princípios norteadores.

Por fim, lançamos mãos ao trabalho de "decifrar os julgamentos e sentenças", questionando as "fórmulas técnicas dos tribunais". Por meio de alguns dos mais importantes acórdãos proferidos sobre a questão da greve política, apontamos a falibilidade dos raciocínios que buscam limitar o exercício da greve política.

A greve é um importante meio de fortalecimento da solidariedade entre os trabalhadores, de instrumento para uma melhoria constante das suas condições de vida e de desenvolvimento de uma consciência coletiva. Entretanto, na atual conjuntura a greve é indevidamente controlada e subjulgada tanto em seu processo de formação quanto em suas finalidades.

Questionamos no decorrer do trabalho os entendimentos majoritários que tratam da matéria, apontando detalhadamente as falhas que os permeiam. Através da contestação destas visões restritivas da greve política, buscamos traçar um caminho que permita o pleno exercício deste direito pelos trabalhadores.

${ }^{143}$ EDELMAN, Bernard. Op. cit., p.17. 
Iniciamos nossos estudos cientes de que nos filiamos a uma visão minoritária em relação ao direito de greve política. Isto só reforçou a necessidade deste estudo. Tanto a doutrina como a jurisprudência majoritárias sustentam que a greve política é ilícita, como pudemos observar ao longo deste trabalho. Contudo, ficamos positivamente surpresos com a análise de alguns votos e divergências que, embora tímidos, representam uma possível superação do conceito restritivo do direito de greve.

A função inicial desta dissertação era apenas demonstrar a insuficiência do conceito de greve política utilizada por nossa jurisprudência. Porém, ao apontar os erros, limitações e contradições cometidos em decisões judiciais este estudo foi além, configurando um norte para a resolução destes problemas.

Mais de um quarto de século se passou desde a promulgação da Constituição Cidadã e ainda estamos lutando pela conscientização de nossos julgadores para a efetividade da norma constitucional relativa ao direito de greve. Esperamos que este trabalho, ainda que limitado a uma análise muito específica, contribua para fomentar o debate acerca da greve política e auxilie em uma necessária mudança da jurisprudência dominante.

Mas nosso objetivo não se esgota com esta dissertação; ao apontarmos as contradições de nossa jurisprudência abrimos caminho para um questionamento mais amplo em relação às greves políticas: Qual a amplitude do exercício da greve? Quais os limites para a regulamentação do fato de greve? Afinal, o que é política para o Direito? Não há respostas simples para estas perguntas, mas estamos certos de que, com este trabalho, demos alguns passos em direção a uma resposta. 


\section{REFERÊNCIAS BIBLIOGRÁFICAS}

ALIPRANTIS, Nikitas. La grève, un droit encore juridiquement méconnu. Annales de la Faculté de droit de Strasbourg, Nouvelle Série n॰6, Le droit social - Le droit comparé. Strasbourg : Presses Universitaires de Strasbourg, 2003, p.15/23.

ANDRADE, Bonavides Paes de. História Constitucional do Brasil. 3*Ed. Rio de Janeiro: Paz e Terra, 1991.

ANTUNES, Ricardo (org). Riqueza e miséria do trabalho no Brasil. São Paulo: Boiempo, 2006.

. A Rebeldia do Trabalho - O confronto operário no ABC paulista: as

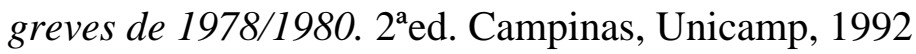
Os sentidos do trabalho. São Paulo: boitempo, 2007. . Continente do labor. São Paulo: Boitempo, 2012

BAILLY, Maxime. Grève : licéité d'une grève de solidarité. JCP S, 2011, n॰15, p.31. BOBBIO, Norberto. O futuro da Democracia. 10ª edição. São Paulo: Paz e Terra, 2006.

BONAVIDES, Paulo. Curso de Direito Constitucional. 26a Ed. São Paulo: Malheiros, 2011

BRAGA, Ruy. A política do precariado. São Paulo: Boitempo, 2012

CALAMANDREI, Piero. Significato costitzionale del diritto di sciopero, Riv.GL, 1953, I,.

CAUCHOIS, Didier. Les limites au droit de grève. Action juridique CFDT, 2006, n॰178, p.15.

CAUPERS, João. Os Direitos Fundamentais dos Trabalhadores e a Constituição. Lisboa: Almedina, 1985.

CAVALCANTI, Temístocles Brandão. A Constituição Federal Comentada. Rio de Janeiro: José Konfino, 1949, Vol. IV.

CESARINO JUNIOR, A. F.. Direito Social Brasileiro. Rio de Janeiro: Freitas Bastos, 1957.

COELHO, Rogério. A greve, os Grevistas e os Não Grevistas, in Revista LTr no 07 nov/89. São Paulo: LTr, 1989.

COMPARATO, Fabio Konder. O papel do juiz na efetivação dos direitos humanos, in Direitos humanos: visões contemporâneas. Revista de comemoração dos 100 anos da Associação dos Juízes para a Democracia, São Paulo, 2001.

CORREIA, Marcus Orione G. (org). Curso de Direito do Trabalho. São Paulo: LTr, 2007, vol. I.

CORREIA, Marcus Orione G. e MAIOR, Jorge L.S. (org). Curso de Direito do Trabalho. 
São Paulo: LTr, 2008, vol. III

COSER, Lewis. The Functions of social conflict. London: Routledge and Kegan, 1956

COSTA, Orlando Teixeira da. Direito Coletivo do Trabalho e crise econômica. São Paulo: LTr, 1991.

COUTURIER, Gérard. Traité de droit du travail - Les relations collectives de travail. Paris : Presses Universitaires de France, 2001.

DA SILVA, José Afonso. Curso de Direito Constitucional Positivo. 30ªed. São Paulo: Malheiros, 2008, P.305.

DAHRENDORF, Ralf. As Classess e Seus Conflitos na Sociedade Industrial. Brasília: UNB, 1982.

DARMAISIN, Stéphane. Qu'est-ce qu'une revendication professionnelle susceptible de légitimer une grève? JCP-S, 2006, n॰42, p.34.

DEJOURS, Christophe. A banalização da injustiça social. São Paulo: FGV, 1999.

DEL CASTILLO, Santiago Perez. O Direito de Greve. São Paulo: LTr, 1994.

DELGADO, Mauricio Godinho. Curso de Direito do Trabalho. $4^{\mathrm{a}}$ Ed. São Paulo: LTr, 2005.

DOCKÉS, Emmanuel ; PESKINE, Elsa ; WolMARK , Cyril. Droit du travail. $5^{\mathrm{e}}$ Édition, Dalloz, 2009.

DOCKÈS, Emmanuel. La finalité des grèves en question. Droit Social, 2006, no 9/10, p. $881 / 889$.

DUQUESNE, François. Droit du Travail. $2^{\mathrm{e}}$ Édition, Paris : Gualino éditeur, 2006.

EDELMAN, Bernard. O direito captado pela fotografia. Centelha: Coimbra, 1976

Chistian Bourgois, 1978.

La légalisation de la classe ouvrière - Tome 1: 1'entreprise. Paris:

FERNANDES, Antônio Monteiro, Greves Atípicas: Identificação, caracteres, efeitos jurídicos; in Temas de Direito do Trabalho - Direito do Trabalho na Crise. Poder empresarial. Greves Atípicas, IV Jornadas Luso-hispano-brasileiras de Direito do Trabalho. Coimbra: Coimbra, 1990.

GOMES, Orlando e GotTschalk, Elson. Curso de Direito do Trabalho. $12^{\mathrm{a}}$ Ed. Rio de Janeiro: Forense, 1991.

GROUX, Guy; Pernot, Jean-Marie. La Grève. Paris: Les Presses Sciences-Po, 2008.

JAVILIER, Jean-Claude. Les conflits du travail. Paris : PUF, 1981

KROTOSCHIN, Ernesto. Tratado práctico de derecho del trabajo. Volumen II, $4^{\mathrm{a}}$ Ed. Buenos Aires: Depalma, 1981.

LAIGNEAU, Marianne ; RAY, Jean-Emmanuel ; MATHIEU, Bertrand. Entreprise, droits fondamentaux et droits sociaux. Les nouveaux Cahiers du Conseil constitutionnel, 2011, n 
31, p.195.

LANDIER, Hubert ; LABBE, Daniel. Les organisations syndicales en France. $2^{\mathrm{e}}$ Édition, Liaisons, 2004.

LATOURNERIE, Roger. Le droit français de la grève. Paris : Sirey, 1972.

LEAL, Antonio da Silva. O conceito de greve e o problema das fontes terminológicas e conceituais do Direito do Trabalho, in Temas de Direito do Trabalho - Direito do Trabalho na Crise. Poder empresarial. Greves Atípicas, IV Jornadas Luso-hispanobrasileiras de Direito do Trabalho. Coimbra: Coimbra, 1990.

LYON-CAEN, Gérard; Pelissier, Jean; SuPIOT, Alain. Droit du Travail. $17^{\circ}$ Ed. Paris: Dalloz, 1994.

LYON-CAEN, Gérard. La concentration du capital et le droit du travail. Droit Social, 1983, p.287.

MAGANO, Octávio Bueno. Greve. In Revista LTr ago/92. São Paulo: LTr, 1992.

MAIOR, Jorge Luiz Souto. Justiça do Trabalho: a justiça do trabalhador. In COUTINHO, Grijalbo Fernandes \& FAVA, Marcos Neves (coord.). Nova Competência da Justiça do Trabalho. São Paulo: LTr, 2005. (P. O Direito do Trabalho como Instrumento de Justiça Social. São

Paulo: LTr, 2000.

. A Fúria, in Revista LTr - Legislaçao Trabalhista, nov/2002, São Paulo: LTr, 2002. PP.1287/1309.

Curso de Direito do Trabalho - Teoria Geral Do Direito do Trabalho. Volume I, Parte I. São Paulo: LTR, 2011

Greve e Salário. Disponível em

<www.migalhas.com.br/dePeso/16,MI109693,81042-Greve+e+salario〉. Acesso em $05 / 12 / 2012$

MARTINS, Ildélio (org). Temas de Direito do Trabalho - Direito do Trabalho na Crise. Poder empresarial. Greves Atípicas, IV Jornadas Luso-hispano-brasileiras de Direito do Trabalho. Coimbra: Coimbra, 1990.

MARTINS, Norma Izabel Ribeiro. Direito de Greve. Brasília: Serviço de Informação Legislativa, 1964.

MARTINS, Sérgio Pinto. Direito do Trabalho, 23ํedição. São Paulo: Atlas, 2007.

MAZEAUD, Antoine. Droit $d u$ travail. $7^{\mathrm{e}}$ Édition, Lextenso, 2010.

MELGAR, Alfredo Montoya. Derecho del Trabajo. 19ª ed. Madrid: Tecnos, 1998.

MONIS, Carlos López. O Direito de Greve: experiências internacionais e doutrina da OIT. São Paulo: LTR, 1986

MORAES FILHO, Evaristo de. Direito de Greve. In Revista LTr Julho/86. São Paulo: LTr, 1986. 
MORAES, Evaristo de. Apontamentos de direito operário. Imprensa Nacional, Rio de Janeiro, 1905.

NASCIMENTO, Amauri Mascaro. Compêndio de Direito Sindical. $4^{\mathrm{a}}$ Edição. São Paulo: LTr, 2006. . Direito sindical. São Paulo: LTR, 1982

OFFE, Claus, Capitalismo desorganizado. São Paulo: Brasiliense, 1989.

OLIVEIRA, Francisco de. Corporativismo: Conceito ou Emplastro, In Democracia Viva, Rio de Janeiro: Ibase, n³, Julho de 1998.

OLIVEIRA, Roberto Verás de. Sindicalismo e Democracia no Brasil: do Novo Sindicalismo ao Sindicato Cidadão. São Paulo: Annablume, 2011.

Boitempo, 2006. Crítica à razão dualista / O ornitorrinco. São Paulo:

OLLIER, Pierre-D. Le droit Du travail. Paris: Librairie Armand Colin, 1972.

PACHUKANIS, E.B. Teoria Geral do Direito e Marxismo. São Paulo: Acadêmica, 1988.

PÉLISSIER, Jean ; LYON-CAEN, Antoine ; JEAMMAUD, Antoine ; DOCKÈS, Emmanuel. Les grands arrêts du droit du travail. $4^{\mathrm{e}}$ Édition, Paris : Dalloz, 2008.

PESCHAUD, Henri. Qu'est-ce qu'une revendication professionnelle ? Légi Social 1999, n 68, p.12/16.

PETERSON, Florence. Sindicatos Operários Norte-Americanos. Rio de Janeiro: Agir, 1953.

RAMAlHO, Maria do Rosário Palma. Da Autonomia Dogmática do Direito do Trabalho. Coimbra: Almedina, 2000. . Lei da Greve. Lisboa: Lex, 1994.

RAY, Jean-Emmanuel. Droit du Travail Droit Vivant. 19e édition. Éditions Liaisons, 2010. RAYNAUD, Philippe. Le juge et le philosophe. Paris : Armand Colin, 2008

RIZEK, Cibele Saliba. A greve dos petroleiros. Revista Praga. São Paulo, setembro de 2008

RUPRECHT, Alfredo J. Relações Coletivas de Trabalho. Trad. Edílson Alkmin Cunha. São Paulo : LTr, 1995.

RUSSOMANO, Mozart Victor. Princípios Gerais de Direito Sindical. Rio de Janeiro: Forense, 1995.

SANTOS, Boaventura de Souza. Introdução a uma ciência pós-moderna. 4*Ed. São Paulo: Graal, 2003.

SANTOS, Roberto A. O. A greve dita abusiva e a cláusula da comunidade, in Suplemento 
Trabalhista LTr n.108. São Paulo: LTr, 1990.

Uma contribuição sociológica à renovação da teoria jurídica da greve. In Revista da Academia Nacional de Direito do Trabalho. São Paulo: LTr, 1993.

SEN, Amartya. A ideia de justiça. São Paulo: Companhia das Letras, 2011.

SILVA, Otavio Pinto e. Negociação coletiva em tempos de reforma sindical. In Revista do Advogado (São Paulo), São Paulo, v. 26, n. 6, p. 63-68, 2006.

. O Brasil precisa de uma reforma sindical?. In: Otavio Pinto e Silva, Enoque Ribeiro dos Santos, (Coords.); Silmara Cosme Cravo, Tamira Maira Fioravante (Orgs.). Temas Controvertidos do Direito Coletivo do Trabalho no Cenário Nacional e Internacional. São Paulo: Editora LTr, 2006, V. , p. 9-26.

SELLIER, F. Stratégie de la lute sociale, Paris: Les Editions Ouvrières, 1961.

SIAU, Bruno. Nouveaux regards jurisprudentiels sur la grève de solidarité. Revue Lamy Droit des Affaires (online), 2011.

SINAY, Hélène. Traité de Droit du Travail - La Gréve. Paris: Dalloz, 1966.

SIROT, Stéphane. La grève en France : une histoire sociale (XIX-XX siècle). Paris : Éditions Odile Jacob, 2002.

SUPIOT, Alain. Revisiter les droits d'action collective. Droit Social, 2001, p.687

SÜSSEKIND, Arnaldo; MARANHÃo, Délio; Vianna, Segadas. Instituições de Direito do

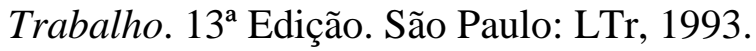

Trabalho. Rio de Janeiro: Freitas Bastos, 1984, V.2. Instituições de Direito do

TEYSSIÉ, Bernard. Droit du travail : Relations collectives. $6^{\mathrm{e}}$ Édition, Paris: LexisNexis, 2009.

THEODORO JÚNIOR, Humberto. Direito e Processo. Belo Horizonte: Del Rey, 1996.

VALVERDE, Antonio M., GutiÉRrez, Fermín R.S., MurCiA, Joaquín G. Derecho Del Trabajo. $5^{\text {a }}$ Ed. Madrid: Tecnos, 1996.

VERDIER, Jean-Maurice; COEURET, Alain; SOURIAC, Marie-Armelle. Droit du travail : Rapports collectifs. $15^{\mathrm{e}}$ Édition, Paris: Dalloz, 2009.

VERDIER, Jean-Maurice. Syndicats et droit syndical - Vol. II :le droit syndical dans l'entreprise. $2^{\mathrm{e}}$ Édition, Paris: Dalloz, 1984.

VIANA, Márcio Túlio. Direito de Resistência. São Paulo: LTr, 1996.

VIDAL NETO, Pedro e NASCIMENTO, Amauri Mascaro. Direito de greve: coletânea de Direito do Trabalho. São Paulo: LTr, 1984.

SILVA, Walküre Lopes Ribeiro da . Impacto das inovações tecnológicas e da reestruturação produtiva sobre a organização e atuações coletivas.. Revista do Tribunal Regional do Trabalho da Décima Quinta Região, Campinas,, n. 25, p. 107-138, 2004. 
Autonomia privada coletiva e o Direito do Trabalho. In

Revista de Direito do Trabalho, São Paulo, v. 26, n. 97, p. 27-39, 2000.

A disciplina jurídica da greve e as Constituições republicanas no Brasil.In Revista da Procuradoria Geral do Estado de São Paulo, São Paulo, n. 39, p. 143-163, 1993.

SILVA, Walküre Lopes Ribeiro da ; MAIOR, Jorge Luiz Souto. Validade e eficácia da Convenção n. 158 da OIT perante o ordenamento jurídico brasileiro. In Revista de Direito do Trabalho, São Paulo, v. 25, n. 94, p. 7-23, 1996.

\section{Filmografia}

BERRI, Claude. Germinal. Belgica/França/Itália, 1993.

CLAIR, René. A nós a liberdade. França, 1931.

CONINX, Stijn. Daens - Um grito de justiça. Belgica/França/Holanda, 1993.

DE SANTIS, Giuseppe. Arroz Amargo. Itália, 1949.

EISENSTEIN, Sergei. A greve. URSS, 1924.

FORD, John. Vinhas da Ira. EUA 1940.

GODARD, Jean-Luc. Tudo vai bem. França, 1972. Film Socialism. França, 2010.

HIRSZMAN, Leon. ABC da greve. Brasil, 1990. . Eles não usam black-tie. Brasil, 1981. . São Bernardo. Brasil, 1971.

REITMAN, Jason. Obrigado por fumar. EUA, 2006.

TAPAJÓS, Renato. Linha de montagem. Brasil, 1982.

WAJDA, Andrzej. O homem de mármore. Polônia, 1977. . O homem de ferro. Polônia, 1981. 


\section{ANEXOS}

Nesta parte, juntamos os julgados que não estão disponíveis on-line, referentes às greves de 19781980 no ABC paulista e a greve dos petroleiros de 1995. As demais decisões estão disponíveis nos sites dos respectivos tribunais. Juntamos também a decisão relativa à PUC São Paulo, eis que se trata da decisão mais atualizada sobre a questão.

ANEXO 01 p.137

Dissidio Coletivo de 1978 - Saab Scania (Decisão do TRT/SP)

ANEXO 02 p.142

Dissidio Coletivo de 1978 - Saab Scania (Decisão do TST)

ANEXO 03 p.147

Dissidio Coletivo de 1979 - Metalúrgicos de São Bernardo (Decisão do TRT/SP)

ANEXO 04 p. 149

Dissidio Coletivo de 1980 - Metalúrgicos de São Bernardo (Decisão do TRT/SP)

ANEXO 05 .p. 155

Dissidio Coletivo de 1980 - Metalúrgicos de São Bernardo (Decisão do TST)

ANEXO 06. .p.156

Dissidio Coletivo de 1995 - Greve dos petroleiros. (Decisão do TST)

ANEXO 07 p.171

Dissidio Coletivo de 2012 - Greve na PUC/SP (Decisão do TRT/SP) 


\title{
ANEXO 01
}

\author{
Dissidio Coletivo de 1978 - Saab Scania Processo 99/78
}

Decisão do Tribunal Regional do Trabalho da $2^{\mathrm{a}}$ Região

(Os respectivos originais pertencem aos autos judiciais provenientes do Tribunal Regional do Trabalho da $2^{\text {a }}$ Região)

\section{Processo TRT/SP 99/78 - Dissidio Coletivo A.B.C. Capital/SP Acórdão n³255/78}

V I S T O S, relatados e discutidos estes autos de Dissídio Coletivo (Processo TRT/SP-99/78) A.B.C. Capital - São Paulo, em que figuram como Suscitante: PROCURADORIA REGIONAL DO TRABALHO DA SEGUNDA REGIÃO e como Suscitados: SAAB - SCANIA D0 BRASIL S/A. - MERCEDES BENZ DO BRASIL S/A. - FORD DO BRASIL S/A. - KARMANN GHIA DO BRASIL S/A.- SINDICATO NACIONAL DA INDÚSTRIA DE TRATORES, CAMINHÕES, AUTOMÓVEIS E VEÍCULOS SIMILARES - SINDICATO NACIONAL DA INDÚSTRIA DE COMPONENTES PARA VEÍCULOS AUTOMOTORES - FEDERAÇÃO DAS INDÚSTRIAS DO ESTADO DE SÃO PAULO - SINDICATO DOS TRABALHADORES NAS INDÚSTRIAS METALÚRGICAS, MECÂNICAS E DE MATERIAL ELÉTRICO DE SÃO BERNARDO DO CAMPO E DIADEMA e FEDERAÇÃO DOS TRABALHADORES NAS INDÚSTRIAS METALÚRGICAS, MECÂNICAS E DE MATERIAL ELÉTRICO NO ESTADO DE SÃO PAULO;

ACORDAM os Juízes do Tribunal Regional do Trabalho da Segunda Região, preliminarmente, levantada questão de ordem, por maioria, em determinar que falasse em primeiro lugar o patrono inscrito pelas empresas e, a seguir o inscrito pelo Sindicato dos Trabalhadores nas Indústrias Metalúrgicas, Mecânicas e de Materíal Elétrico de São Bernardo do Campo, vencidos os Exmos. Srs. Juízes Oswaldo Perez, Roberto Barretto Prado, Ermelindo Soares de Camargo, Élsio Castellani, Nelson Ferreira de Souza e Plínio Ribeiro de Mendonça; ainda, preliminarmente, por unanimidade, em dar pela constitucionalidade da Lei $\mathrm{n}^{\circ} 4$ 330, de 1964, rejeitando a prejudicial arguída pelo Sindicato dos Trabalhadores, bem como, por maioria, em dar pelo conhecimento do dissídio coletivo, vencidos os Exmos. Srs. Juízes Élsio Castellani e Antônio Lamarca; no mérito, por maioria, em dar pela ilegalidade da paralisação do trabalho, determinando o retorno dos empregados ao serviço no dia 19 do corrente, deixando a critério das empresas o pagamento ou não das horas ou dias de paralisação, vencidos, em parte,os Exmos. Srs. Juízes: Oswaldo Perez, Ermelindo Soares de Camargo e José de Barros Vieira Júnior, que determinando a volta ao trabalho, asseguravam aos empregados percepção dos salários dos dias de paralisação; Caio Cesar Netto, Reginaldo Mauger Allen, Nelson Virgílio do Nascimento, Homero Diniz Gonçalves e Roberto Barretto Prado, que expressamente desobrigavam as empresas do pagamento dos salários; Antônio Lamarca, Bento Pupo Pesce, Marcelino Marques, Nelson Virgílio do Nascimento, Reginaldo Mauger Allen e Caio Cesar Netto, que deixavam de estabelecer prazo para a volta dos empregados ao trabalho; Roberto Barretto Prado, que determinava o prosseguimento do dissídio coletivo em seus termos regulares; e Marcelino Marques, que dava pela legalidade do movimento de paralisação.

\section{Custas na forma da lei.}

Trata-se de dissídio coletivo suscitado pela Procuradoria Regional do Trabalho da Segunda Região, face aos elementos constantes dos autos, coligidos pela Delegacia Regional do Trabalho, informando da eclosão do movimento grevista envolvendo trabalhadores de diversas indústrias do setor automobilístico do $\mathrm{ABC}$., sem que tivesse havido a possibilidade a uma solução conciliatória na esfera administrativa.

Designada audiência de conciliação e instrução para o dia 17 de maio de 1.978 , as partes dissidentes se fizeram presentes, e apesar de todos os esforços da Presidência deste Tribunal no sentido de se encontrar uma solução conciliatória para por termo ao dissídio, esse propósito não poude ser alcançado. A proposta conciliatória da presidência no sentido do retorno imediato ao trabalho, com a cessação do 
movimento grevista, com o prosseguimento dos entendimentos visando a solução da pendência, não foi atendida.

A D. Procuradoria Regional do Trabalho desta 2a. Região, opinou às fls. 59 "usque" 61, no sentido da ilegitimidade das paralisações do trabalho, por inobservância de exigências legais.

É o relatório.

VOTO:

A paralisação do trabalho de que nos dá notícia os presentes autos, decorreu da comunicação dirigida à Delegacia Regional do Trabalho, neste Estado, pela empresa, Saab Scania, situada no Município de São Bernardo do Campo, cuja paralisação se efetivou a partir do dia 12 de maio, iniciada na ferramentaria da fábrica de motores, estendida, posteriormente, à fábrica de eixos, montagem de chassis e departamento de manutenção (fls. 3).

A versão dada pela empresa pre-citada, foi examinada pelo Sr. Assistente Sindical,

manifestando-se:

"O que se faz sentir, através do esclarecido pela nossa Sub Delegacia de S. Bernardo do Campo, que a entidade sindical representativa da categoria, ou seja, o Sindicato dos Trabalhadores nas Indústrias Metalúrgicas, Mecânicas e de Material Elétrico de S. Bernardo do Campo, nada ou pouco esforço faz para a realização de uma assembléia, com o fim de esclarecer os trabalhadores da ilegitimidade do movimento.

Os estatutos sociais das entidades sindicais, conforme o que determina a alínea "a" do artigo 518 da C.L.T., tem a afirmação que as mesmas agirão como órgãos de colaboração com os poderes públicos e as demais associações no sentido da solidariedade social e de subordinacão dos interesses econômicos ou profissionais ao interesse nacional. (o grifo é nosso).

Sendo pois, o movimento ora em evidência totalmente contrário às normas determinadas na legislação, é de bom alvitre que se faça a convocação dos representantes do Sindicato, para que cumpram os dispositivos legais, não só envidando esforços junto aqueles trabalhadores, com o fim de efetuar esclarecimentos da incorreção de tal ato, como também dos prejuízos que poderão advir para os mesmos e para a nação."

O Sr. Delegado Regional, uma vez esclarecido, determinou a convocação dos Sindicatos, Federações, representantes de empresa e a E. Procuradoria Regional do Trabalho, para reunião na sede da delegacia, tudo conforme termo de fls. 23/25.

Compareceram à audiência designada para o dia 16.05.78, entidades sindicais e empresas: FEDERAÇÃO DAS INDÚSTRIAS DO ESTADO DE SÃO PAULO, SINDICATO NACIONAL DA INDÚSTRIA DE TRATORES, CAMINHÕES, AUTOMÓVEIS E VEÍCULOS SIMILARES, SINDICATO NACIONAL DA INDUSTRIA DE COMPONENTES PARA VEICULOS AUTOMOTORES SINDIPEÇAS, FEDERAÇÃO DOS TRABALHADORES NAS INDUSTRIAS METALURGICAS, MECÂNICAS E DE MATERIAL ELÉTRICO NO ESTADO DE SÃO PAULO, SINDICATO DOS TRABALHADORES NAS INDUSTRIAS METALURGICAS, MECÂNICAS E DE MATERIAL ELÉTRICO DE SÃO BERNARDO DO CAMPO, MERCEDES BENZ DO BRASIL S.A., SAAB - SCANIA DO BRASIL S.A., FORD DO BRASIL S.A., KARMANN GHIA DO BRASIL S.A.

O Ministério Público do Trabalho fez-se presente na pessoa do seu titular Exmo. Sr. Dr. Pau1o Chagas Felisberto.

As partes não chegaram a uma solução, tendo o Exmo. Sr. Dr. Procurador Regional do Trabalho solicitado a remessa do expediente, com urgência à Justiça do Trabalho (fls. 25 e 48/49) como segue:

"Consta dos presentes autos, a ocorrência de paralisação de trabalho da empresa Saab-Scania do Brasil S.A., na Mercedes Benz do Brasil, na Ford do Brasil S.A. e outras empresas da categoria economica representada pelo Sindicato Nacional da Indústria de Tratores, Caminhões, Automóveis e Veículos Similares, sendo certo que os empregados grevistas ou em vias de declararem a paralisação do trabalho em outras empresas, integram a categoria profissional representada pelo Sindicato dos Trabalhadores nas Indústrias Metalúrgicas, Mecânicas e de Material Elétrico de São Bernardo do Campo, inclusive com relação a outras da categoria econômica representada pelo Sindicato Nacional da Indústria de Componentes para Veículos Automotores também na iminência de presenciarem a paralisação dos trabalhos por parte de seus empregados, situação essa de fato criada em decorrência da pretensão dos empregados em obterem a não compensação do aumento espontâneo na ordem de $20 \%$ em algumas empresas e $15 \%$ em 
outras, com relação ao que fora ordenado pelo V. Acórdão prolatado nos autos do Dissídio Coletivo da mencionada categoria profissional, em abril do fluente ano.

Aliás, a pretensão dos empregados integrantes de dita categoria profissional, não só se tornou pública e notória, à vista das edições dos jornais de maior porte desta Capital, do dia de hoje, como vêm claramente estampada no expediente de fls. 3 a 5 dos autos, que motivou a reunião processada na Delegacia Regional do Trabalho, com a presença das partes, cuja respectiva Ata espelha as reivindicações dos empregados, sendo de ressaltar que uma vez frustrados os objetivos da reunião conciliatória verificada na fase administrativa, eis que as partes apenas procuraram consignar seu ponto de vista, o Sr. Delegado Regional do Trabalho no Estado de São Paulo em acolhendo parecer do Doutor Assistente Jurídico, houve por bem em encaminhar os presentes autos ao Egrégio Tribunal Regional do Trabalho, para os devidos fins de direito.

A vista do exposto e, considerando o que dispõe a Lei n9 4.330, de $1^{\circ}$ de junho de 1964, que "Regula o direito de greve" consoante mandamento constitucional e, tendo em conta como já foi apreciado nos autos pela Delegacia Regional do Trabalho a flagrante ilegalidade do movimento paredista ocorrido em algumas empresas e na iminência de ser alargado, abrangendo outras da categoria econômica precitada, cujos empregados íntegram à categoria profissional representada pelo Sindicato dos Trabalhadores nas Indústrias Metalúrgicas, Mecânicas e de Material Elétrico de São Bernardo do Campo, considerando o que preceitua o artigo 856 da Consolidação das Leis do Trabalho, esta Procuradoria Regional da Justiça do Trabalho da Segunda Região, vem instaurar a instância do dissídio coletivo, a fim de serem apreciadas as reivindicações dos trabalhadores, representados pelo Sindicato dos Trabalhadores nas Indústrias Metalúrgicas, Mecânicas e de Material Elétrico de São Bernardo do Campo, reivindicações essas apresentadas às empresas mencionadas, integrantes da categoria econômica representada pelo Sindicato Nacional da Indústria de Tratores, Caminhões e Automóveis e Veículos Similares e pelo Sindicato Nacional da Indústria de Componentes Veículos Automotores, afigurando-se recomendável, na forma da lei, a convocação também da Federação das Indústrias do Estado de São Paulo, dos Representantes das empresas mencionadas e da Federação dos Trabalhadores nas Indústrias Metalúrgicas, Mecânicas e de Material Elétrico no Estado de São Paulo para a audiência de conciliação e o regular processamento do feito, até final, na esfera judicial."

Tem-se, assim, por virtualmente cumprido o $\S 2^{\circ}$, do art. 10, da Lei $\mathrm{n}^{\circ} 4330$, de 03.06.64, em vista da suscitação "ex-officio" do dissídio coletivo, pelo Ministério Público do Trabalho.

Vieram os autos a esta Côrte, quando então o Sr. Presidente determinou, nos termos do $\S$ único do art. 860, da CLT, notificação dos dissidentes, dentro de curto prazo. Foi realizada a audiência, constante as fls. 50 "usque" 56, com o comparecimento do representante do Ministério Público, ora Suscitante (art. 23, da Lei 4330/64) e das partes interessadas, perfeitamente,qualificadas, a esta altura, como dispõe a CLT. Ainda, na referida audiência,"o Sindicato dos Metalúrgicos de São Bernardo do Campo e Diadema fiel aos seus deveres legais e atento às necessidades de seus representados, assumiu o comando das negociações, visando compor os interesses, tendo em vista também o bem comum e os interesses da patria" (sic fls. 51).

Foi examinada a constitucionalidade da Lei 4.330/64, tendo as empresas suscitadas levantado a ilegalidade da greve.

A constitucionalidade da Lei 4.330, de 03.06.64 não é de ser acolhida, isto porque, a Carta Magna vigente não lhe tirou propriedade legal.

É princípio assente pelas mais altas Cortes do Judiciário, da cristalização das leis preexistentes à constituição, daí viger normalmente, pois, d'outra forma, ter-se-ia a revogação geral de toda a legislação de então dos diversos ramos do direito. Evidentemente, as leis são, virtualmente, revogadas ou anuladas pela Carta Maior quando se opuseram ao espírito da norma constitucional.

O inciso XX, do art. 165, da Emenda Constitucional n ${ }^{\circ} 1 / 69$, dispõe:

"greve, salvo o disposto no artigo162", mas, tem de ser, segundo a hermenêutica, analisado em função do"caput" definidor.

Diz: art. 165 -"A constituição assegura aos trabalhadores os seguintes direitos, além de outros que, nos termos da lei, visem à melhoria de sua condição social“".

Portanto, a Lei 4.330/64, asseguradora do direito de greve, embora, pre-existente à carta magna, de 69, data venia de entendimentos contrários, está em pleno vigor, isto porque, o texto constitucional se refere expressamente "nos termos da lei", evidentemente, ratificando a lei anteriormente sancionada, pois, não é dado ao legislador deixar de considerar o negócio jurídico de tão alta indagação. Sequer, contém o texto da lei maior, o condicionamento a futura lei ordinária, sobre matéria de greve.

Rejeito a prejudicial de inconstitucionalidade da Lei 4330/64.

Doutra parte, a suscitação está, juridicamente, regulada pelo art. 26, da Lei 4330/74 e art. 856, da CLT. 
"In casu", ocorreu a suspensão do trabalho, sem outras formalidades, o que foi motivo de provocação da empregadora junto à autoridade administrativa e chamado o Ministério Público do Traba1ho, este solicitou a instauração "ex-officio" do presente dissídio coletivo.

1 ei.

Impõe-se o seu conhecimento, já em razão do fato superveniente, já em razão da unidade processua1 fática.

A matéria referente a exclusão de empresas suscitadas, está superada, diante da

A para1isação do traba1ho, por parte dos empregados, a esta altura é fato notório. Resta, finalmente, enquadrá-la sob o fulcro da legalidade ou não.

O permissivo vestibu1ar da paralisação do trabalho está em função de deliberação de assembléia gera1 da entidade sindica1 representativa da categoria profissional, como bem explicitado no art. $2^{\circ}$, da Lei 4330/64. O art.6 ${ }^{\circ}$, do diploma citado, Capítu1o II - "condições para o exercício - do direito de greve, obriga a convocação dos traba1hadores, pe1a Diretoria da entidade sindical, através de edital, quando se descutirá a reivindicação e deliberação do movimento grevista. Ainda, o $\$ 3^{\circ}$, determina seja a assembléia presidida por membros do Ministério Público do Traba1ho. Fina1mente, apurada a votação e lavrada a ata, o membro do Ministério Público do Trabalho remeterá a cópia autêntica do que foi deliberado ao Sr. De1egado do Trabalho.

No caso em apreço, há Sindicato da categoria profissional, entidade essa não exercitada pelos trabalhadores grevistas, cujo movimento paralisou as atividades normais nas empresas suscitadas. D'outra parte, os trabalhadores ou a diretoria da entidade sindical deixou de notificar o empregador, assegurando-1he o prazo de 5 (cinco) dias para a solução pleiteada, sob pena de abstenção pacífica e temporária do traba1ho.

Desrespeitados os dispositivos legais, não se materializou a autorização, por assembléia geral da entidade sindica1, do direito de greve, isto é, da legalidade da paralisação do traba1ho.

Ex positis.

O fato gerador da paralisação, como demonstrado, constitui o ilícito do inciso I, do art. 22, da Lei 4330/64.

Tem-se, consequentemente, por cessada a greve, nos termos do inciso III, do art. 25, da 1ei, com o retorno dos empregados ao serviço, no dia 19 (dezenove) do corrente mês, deixando a critério das empresas, ora suscitadas, o pagamento ou não dos salários das horas ou dias de para1isação.

Custas isentas.

São Paulo,18 de maio de 1978.

PRESIDENTE ROBERTO MARIO RODRIGUES MARTINS

RELATOR NELSON FERREIRA DE SOUZA RELATOR (DESIGNADO)

PROCURADOR PAULO CHAGAS FELISBERTO (CIENTE)

sml.

R. e D. 19.05 .78

\section{VOTO VENCIDO DO EXMO.SR. JUIZ RELATOR OSWALDO PEREZ}

Conheço do dissídio coletivo.

O movimento paredista que nos dá notícia os documentos acostados aos autos, ao que parece surgiu natura1mente, sem que houvesse a participação da entidade de classe ou de outros elementos.

Esse movimento ainda com base nos elementos constantes dos autos, visa assegurar vantagem econômica, isto é a não compensação das antecipações concedidas pelas empresas, variáveis de $15 \%$ a $20 \%$, quando da aplicação dos dissídios coletivos que tiveram vigência a partir de abri1 
de 1978, no percentua1 de 39\%, aumento este concedido por este Tribunal e que expressamente, na forma da legislação vigente, autoriza a compensação de todos os aumentos havidos no decurso do ano-base, sejam eles expontâneos ou compu1sórios.

Esse movimento grevista surgiu praticamente como um ato de inconformismo expontâneo, com os salários que passaram a receber e de cujo valor tomaram conhecimento no momento do seu recebimento, fato que ocorreu a partir do $10^{\circ}$ dia útil do corrente mês de maio.

À decepção seguida à verficação de que a majoração salaria1 fora curta, os traba1hadores, inconscientemente, passaram a produzir menos, daí passando a uma paralização gera1 das atividades nas indústrias.

Assim o movimento grevista, conforme muito bem acentua a Douta Procuradoria, em suas razões ao suscitar o presente dissídio coletivo, embora ilega1, surgiu espontânea e pacificamente.

O movimento grevista não é o resultado de uma ação adrede preparado por agitadores, ou por elementos interessados em sabotar as atividades industriais mas como o resultado natural da insatisfação operária, com a baixa remuneração.

Efetivamente, apesar da indústria automobilística, ser uma das poucas atividades empresariais que remunera satisfatoriamente seus empregados, a grande massa obreira, não tem salário compatível com suas necessidades mínimas.

E mais, justamente os trabalhadores das indústrias automobilísticas são aqueles que sofrem diretamente todos os reflexos negativos da atividade econômica e da própria conjuntura, vivendo sempre um clima de tensão, sujeitos que são, as dispensas cíclicas e periódicas, como ocorreu ainda recentemente. E essas despedidas em massa a1cançam sempre a eles, diretamente.

Assim a própria natureza de suas atividades leva os trabalhadores do setor a ter um comportamento diverso dos demais integrantes da categoria profissional ou mesmo do grupo.

O movimento paredista, que envolve os trabalhadores da categoria dissidente, nos termos da 1ei $n^{\circ} 4.330 / 64$, é efetivamente um movimento ilega1, entretanto, não se pode usar do rigorismo da lei, para abranger aqueles obreiros, porque aquele movimento além

de pacífico é espontâneo e não constitui um movimento de rebelião contra a autoridade, mas simples desbafo.

Parece-nos que a participação da autoridade regiona1 do Ministério do Traba1ho, bem como das entidades de classe, tanto de categoria econômica, como da profissional é que foi tardia e acanhada, gerando desse fato o agravamento da situação.

Se houvesse uma pronta e segura participação dos Sindicatos bem como do Ministério do Trabalho, aquele movimento não teria alcançado a evolução e a repercussão que nos informam os elementos constantes dos autos. Tanto isso é verdadeiro, que ainda ontem, no decurso da audiência, muitos dos trabalhadores pacificamente retornaram às suas atividades, normalizando o trabalho nas empresas.

Já tivemos oportunidade de nos manifestar favoravelmente aos aumentos salariais dos trabalhadores, a ser obtido através de acordo ou convenção coletiva através do diálogo entre as entidades sindicais das categorias econômicas e profissionais, mas nunca pe1o uso da força.

Uma vez que o movimento grevista ainda remanescente em algumas poucas empresas, não constitui efetivamente um elemento de subversão, ou mesmo de desrespeito, porque é um movimento marcadamente reivindicatório e de protesto. Entretanto e1a nos afigura como i1ega1, porque não obedeceu o disposto na Lei 4.330/64, que regula o direito de greve, na forma do artigo 158 da Constituição Federal e atual artigo 165 da emenda Constitucional $n^{\circ} 1$ de 17.10.69.

Pe1o exposto ju1go procedente o presente dissídio coletivo, para reconhecer a ilegalidade da greve, determinando o retorno dos trabalhadores às suas atividades, no entanto, sem prejuízo de seus salários, desde que foi oferecido a outros trabalhadores oportunidade de retornarem às suas atividades, sem prejuízo salarial, conforme noticiam os autos, por questão de equidade.

RELATOR

OSWALDO PEREZ VENCIDO

Mod.

R. e D. 19.05 .78 


\section{ANEXO 2}

Dissidio Coletivo de 1978 - Saab Scania Processo TST RO.DC-387/78

Decisão do Tribunal Superior do Trabalho

(Os respectivos originais pertencem aos autos judiciais provenientes do Tribunal Regional do Trabalho da $2^{\text {a }}$ Região)

A C Ó R D Ã O

(Ac. TP - 1114/79)

$\mathrm{MVR} / \mathrm{mdgs}$

A Lei no 4330/64 não é inconstitucional. Quando a greve se desenvolve em atrito com seus dispositivos, ao juiz compete declará-la ilega1.

Recurso ordinário a que se nega provimento.

Vistos, relatados e discutidos estes autos de Recurso Ordinário em Dissídio Coletivo $\mathrm{n}^{\circ}$ TST-RO.DC-387/78, em que é Recorrente SINDICATO DOS TRABALHADORES NAS INDÚSTRIAS METALÚRGICAS, MECÂNICAS E DE MATERIAL ELÉTRICO DE SÃO BERNARDO DO CAMPO E DIADEMA. e Recorridos PROCURADORIA REGIONAL DA JUSTIÇA DO TRABALHO DA SEGUNDA REGIÃO, SINDICATO NACIONAL DA INDÚSTRIA DE TRATORES, CAMINHÕES, AUTOMÓVEIS E VEÍCULOS SIMILARES e FEDERAÇÃO DAS INDÚSTRIAS DO ESTADO DE SÃO PAULO.

Adoto o relatório, a seguir transcrito, do Exmo. Sr. Ministro RAYMUNDO DE SOUZA MOURA, relator originário:

"O acórdão regional considerou que a paralização do trabalho a que se refere o presente processo foi levada ao conhecimento da Delegacia Regional pela empresa Saab Scania, com sede no município de São Bernardo do Campo, tendo sido iniciada na fábrica de motores e estendida à fábrica de eixos, montagem de chassis e departamento de manútenção, com início em 12.05.1978. Os estatutos das entidades sindicais, conforme o artigo 518, a, da CLT, partem do princípio de que elas são órgãos de colaboração com os Poderes Públicos, no sentido da solidariedade social e de subordinação dos interesses econômicos ou profissionais ao interesse naciona1. O Delegado Regional do Traba1ho convocou os sindicatos, federações e representantes de empresa e da Procuradoria Regional, para reunião, tudo conforme a ata de fls. 23/25, mas as partes não chegaram a uma solução, e daí a remessa do processo à Justiça do Traba1ho, manifestando-se o órgão do Ministério Público em requerimento, de fls. 48/49, no sentido da instrução do feito. A preliminar de inconstitucionalidade da lei $\mathrm{n}^{\circ} 4.330$, de 1964, é de ser rejeitada. O inciso XX, do artigo 165, da Constituição (Emenda $n^{\circ}$ 1, de 1969) deve ser analisado em função do seu caput. A citada lei no 4.330 asseguradora do direito de greve, embora preexistente à Carta Magna de 1969, está em pleno vigor, isto porque o texto constitucional utíliza a expressão "nos termos da 1ei". Evidentemente, ratificou a lei anterior, pois a norma fundamental sequer alude ao condicionamento a futura 1ei ordinária, sobre a matéria de greve. O processo está regulado pe1o artigo 26, da 1ei n 4.330, de 1964, e artigo 856, da CLT. A suspensão do trabalho ocorreu sem outras formalidades. A matéria de exclusão de empresas suscitadas está superada diante da unidade processua1. A paralização do traba1ho por parte dos empregados é fato notório. O permissivo vestibular da paralização do trabalho é relacionado com a deliberação de assembléia geral da entidade sindical representativa da categoria profissional, como determina o artigo $2^{\circ}$. $\mathrm{O}$ artigo $3^{\circ}$ dispõe que a assembléia seja presidida por membro do Ministério Púb1ico. No caso, os trabalhadores não exercitaram a greve através do sindicato respectivo, e não houve a notificação prévia ao empregador, para a solução pleiteada, sob pena de abstenção pacífica e temporária do trabalho. Desrespeitados os dispositivos 1egais, não se materializou a autorização, por assembléia geral, do direito de greve, ou seja, a greve não teve enquadramento legal, caracterizando o ilícito previsto no artigo 22, I, da citada lei $\mathrm{n}^{\mathrm{o}}$ 4.330. Determinou a cessação da greve, nos termos do artigo 25, III, com o retorno dos empregados ao serviço, no dia 19.05.1978, deixando ao critério das empresas o pagamento dos salários das horas ou dias de paralização. 
O Sindicato dos Trabalhadores nas Indústrias Metalúrgicas, Mecânicas e de Material Elétrico de São Bernardo do Campo e Diadema recorreu, alegando que a greve se justifica como base da luta por melhores salários e pela livre negociação com os empresários. A paralização gera1 e espontânea foi a maneira legítima encontrada pelos traba1hadores, ap6s anos e anos de infrutíferas expectativas, para trazer à mesa das negociações os seus patrões. Acontece que a paralização, além de legítima, foi legal. A 1ei $\mathrm{n}^{\circ} 4.330$, de 1964, pretendeu regu1ar o direito de greve, em face do artigo 158, da Constituição de 1946. A norma constitucional permite ao legislador regular o direito de greve, não exc1uí-1o. A Emenda Constitucional de 1969 tornou impossíve1 a greve nos serviços públicos e atividades essenciais (artigo 162). Quanto aos outros serviços, a Carta Constitucional libera de maneira ampla, indo além da própria Constituição de 1946. A Justiça do Traba1ho, assim como não pode legalizar a greve nos serviços púb1icos e atividades essenciais, também não pode declarar ilegal o movimento de idêntica natureza em serviços como os que se desenvolvem nas indústrias automobilísticas. Superada, pois, a questão da legalidade da greve, foram os próprios empregadores que, sentindo a presença de um movimento vigoroso, se encarregaram de 1 he dar cobertura, procurando negociação com o órgão sindical dos traba1hadores. Não se trata de desapreço à sentença do Tribunal Regional, mas, simp1esmente, de uma so1ução que está acima do preceito forma1. Esta greve deve provocar de parte das autoridades e dos empregadores uma nova visão do movimento sindica1.

O Recorrente, pela petição de fls. 119, requereu a juntada da convenção pela qua1 estabeleceu com o sindicato patrona1, em 31.05.1978, aumento de salário a titulo de antecipação do próximo reajustamento, que terá vigor em 2.4.1979.

A d. Procuradoria Gera1 opina contrariamente à preliminar e, no mérito, pela confirmação da sentença."

$$
\text { É o relatório. }
$$

\section{O T O}

a) Preliminarmente - A Carta de 37 declarou a greve um recurso "nocivo e antisocial". Sob o peso da filosofia política do "Estado Novo", o constituinte fechava, dessa maneira, a porta da reivindicação direta e violenta do trabalhador. Mas, ao mesmo tempo, com sabedoria, dentro do espírito da época, ia a1ém dos lindes do direito brasileiro anterior, abrindo, para os sindicatos, duas portas sucessivas, para solução dos conflitos de traba1ho: a convenção coletiva e, muito especialmente, a via jurisdiciona1 ampla da Justiça do Trabalho.

Sob a vigência da Constituição estadonovista, sobreveio, entretanto, o Decreto-Lei $n^{\circ}$ 9070/46, quase às vésperas da promulgação da Constituição de 1946.

Aquele decreto-lei, ao arrepio da Carta de 37, disciplinava o direito de greve, antecipando-se ao constituinte de setembro daquele ano, e seus dispositivos apenas continuaram sendo aplicados porque se tomou como motivo o compromisso internaciona1 adotado pelo Brasi1, sobre a matéria, através da Ata de Chapultegec.

Como o constituinte de 46 admitiu, ao mesmo tempo, a competência normativa da Justiça do Trabalho e reconheceu a greve como direito, o decreto-lei ${ }^{\circ} 9070$ se tornou desajustado à nova ordem polítíca e jurídica do país. Mas, o 1egis1ador ordinário só veio regulamentar o dispositivo constitucional através da Lei $\mathrm{n}^{\circ}$ 4.330/64, que, por isso, foi elaborada e promulgada, rigorosamente, dentro das franquias e das imposições constitucionais da época.

É de se notar que a Lei n9 4.330/64 - por inf1uência do espírito libera1 da Constituição de 46 - era mais amp1a e flexível do que o Decreto-Lei $n^{\circ} 9070$, bastando para isso que se tenha em consideração o elenco das greves proibidas adotado por um e por outro dip1oma lega1.

Sobrevindo, mais tarde, a Constituição de 67, com a Emenda $n^{\circ} 1$, de 69, modificou-se, novamente, o panorama, operando-se um retrocesso, de parte do constituinte, para o regime do Decreto-Lei $n^{\circ}$ 9070, pelo menos quanto à proibição de greve nas atividades fundamentais ou essenciais à economia brasileira. 
O novo texto constitucional diz que é reconhecida a greve e ressalva, apenas, a exceção das greves proibidas por norma da própria Constituição.

Mas, isso não revogou ou tornou inconstituciona1, "data venia", a Lei n 4.330/64, que é 1eí ordinária regulamentadora de preceito da Constituição, uma vez que o novo dispositivo ainda é carente de regulamentação e não atrita com o preceito ordinário anterior.

Se se adotasse o sistema europeu de exegese do texto constituciona1, poder-se-ia dizer que a norma que reconhece o direito de greve, enquanto não for regulamentada, pode ser exercida plenamente, sem limites ou restrições. Mas, no Brasil, nosso Direito Constitucional está preso à tradição e à técnica da lei norte-americana: É preciso distinguir entre os dispositivos programáticos e os preceitos se1fexecuting contidos na 1ei fundamenta1 da Repúb1ica.

Ora, os dispositivos do art. 165, da Constituição em vigor, são programáticos, no self-executing, de modo que, enquanto não sobrevier lei ordinária nova, regulamentando seu inciso XX, continua desempenhando esse papel regulamentador a Lei $\mathrm{n}^{\circ} 4.330 / 64$, que apenas foi revogada no que atrita com o art. 162, da Carta.

Se se entendesse de forma diversa, admitir-se-ia a aplicabilidade irrestricta do inciso XX, do art. 165, e, portanto, a greve, no Brasil, passaria a ser um direito absoluto, a ponto de toda e qualquer regulamentação de seu exercício constituir uma limitação inconstitucional à prerrogativa sindíca1 de iniciar, manter ou estimular movimentos grevistas.

Essa tese, porém, está fora dos quadros universais da Teoria Geral do Direito e, muito particularmente, do Direito Brasileiro.

Assim, a Lei $n^{\circ}$ 4.330/64 não entrou em conflito com a norma superior do art. 165, inciso XX, da Constituição, motivo pelo qua1 rejeito a preliminar suscitada pelo Recorrente.

b) No mérito - Se se admite a constitucionalidade e a plena eficácia da Lei $\mathrm{n}^{\circ}$ 4.330/64, a conclusão natura1 - "data venia" do eminente Re1ator sorteado - será condicionar-se a legalidade da greve ao cumprimento dos requisitos, prazos, etc. estabe1ecidos naque1e dip1oma 1 ega1.

E como isso, "in casu", não foi feito, como demonstrado no r. acórdão recorrido, nego provimento à ape 1 ação, reportando-me aos fundamentos da decisão de primeiro grau, que adoto.

É preciso, apenas, acrescentar duas considerações.

Em primeiro 1ugar, é notório que a situação política brasileira passou e está passando por uma brusca e louváve1 metamorfose, no sentido da democratização de suas instituições. Como a greve é um instituto jurídico muito característico dos regimes liberais - tanto assim que as fórmulas tota1itárias de direita e de esquerda a suprimem do seu direito positivo - é compreensível que se tenha passado a admití-1a, a reconhecê-la, a ap1audí-la e, em certos casos, a estimu1á-la, pondo-lhe sobre os ombros um manto de legalidade em qua1quer caso".

Como, por outro 1ado, a competência normativa da Justiça do Trabalho foi reduzida pela política salarial anti-inflacionária do Governo, diminuiu a importância da sentença judicia1 em conflitos coletivos, aumentando, proporciona1mente, o interesse e a amp1itude prática da negociação direta e, no caso do Brasil, como esta também está restringida, a greve reassumiu o seu reinado, tradicional nos regimes 1iberais.

Não importa, entretanto, ao julgador esse aspecto social ou político da greve, porque existem, no caso, leis expressas. Mesmo que as partes entrem em negociações diretas acima das linhas traçadas pelo 1egislador e mesmo que o Governo da República não só o tolere, mas também o aplauda e consagre essa negociação, o Juiz continua preso ao princípio da 1egalidade, que o obriga a decidir os casos previstos pe1o 1egislador de acordo com a lei taxativa que ele tem nas mãos.

Em segundo lugar, se, no caso "sub iudice", as partes se compuseram, amigavelmente, depois da greve e da sentença recorrida, tri1hando o caminho da negociação coletiva, tanto melhor para as próprias partes e para a comunidade. Isso, no entanto, não altera a definição ou classificação 
jurídica dos fatos anteriores, que são aqueles que estão sob julgamento e devem ser julgados. Se a negociação coletiva foi frutuosa e satisfez os trabalhadores, poderiam estes, é claro, ter desistido do recurso, mas se dele não desistiram, ao Juiz cabe julgá-1o, segundo a interpretação dada à lei vigente.

A interpretação que aqui se adota é consentânea com a jurisprudência deste Tribuna1 Superior; reflete, com exatidão, o texto da 1ei; ta1vez mostre, entretanto, que nova regulamentação do direito de greve se torna urgente e indispensável, para adaptar seu exercício à nova dimensão da realidade social brasileira.

As greves, como nós as estamos conhecendo, no Brasil, são um fato inédito, pe1o seu vigor, pe1a sua extensão e pe1a sua autenticidade. Nesse sentido, as greves brasileiras são as dores do parto democrático. São as dores de dilatação, terríveis e violentas, que constituem risco calculado em todas as délivrances.

Legais ou ilegais - no caso, ilegal - as greves acarretam para trabalhadores e empresários consequiências e é do bom jogo democrático suportar essas consequiências, quando más, como ocorre agora, ou desfrutá-1as, quando benéficas, como ocorreu através da negociação coletiva de que estes autos dão notícia.

\section{$\underline{\text { ISTOPOSTO }}$}

A C O R D A M os Ministros do Tribunal Superior do Traba1ho, por unanimidade, rejeitar a prelíminar de inconstitucionalidade da Lei número quatro mil trezentos e trinta (4.330) de mil novecentos e sessenta e quatro (1964); no mérito, negar provimento ao recurso, vencidos os Excelentíssimos Senhores Ministros Raymundo de Souza Moura, Orlando Coutinho e Juiz Washington da Trindade. Deu-se por impedido o Excelentíssimo Senhor Juiz Roberto Mário. Justificará o voto o Excelentíssimo Senhor Ministro Raymundo de Souza Moura.

Brasília, 28 de maio de 1.979.

JOÃO DE LIMA TEIXEIRA Presidente

MOZART VICTOR RUSSOMANO Relator "ad hoc"

Ciente: $\quad$ MARCO AURÉLIO PRATES DE MACEDO Procurador Gera1

\section{JUSTIFICAÇÃO DE VOTO VENCIDO DO EXM ${ }^{\circ}$ SR. MINISTRO RAYMUNDO DE SOUZA} MOURA.

Convém acentuar, preliminarmente, nos termos do Prejulgado 56, item II, que a instauração da instância por iniciativa do Ministério Público, ou em virtude do malogro de negociação coletiva de âmbito administrativo, será promovida mediante representação dirigida ao Presidente do Tribunal, contendo, pe1o menos, a designação e a qualificação dos interessados e os motivos do dissídio. Em qualquer destas hip6teses, a representação será acompanhada do correspondente processo administrativo, ressalvada a hipótese de instauração pelo Presidente do Tribunal.

No caso, o processo administrativo ao invés de ser apensado à representação, serviu-1he de ponto de partida, de modo que consta, a título de inicial do processo, simples memorando da empresa Saab Scania. A petição inicial deveria ser o requerimento de f1s. 48/49, do Dr. Procurador Regiona1. O procedimento, tal como foi realizado, contrariando o aludido Prejulgado, se não chega a constituir nulidade, todavia caracteriza irregularidade tumultuando o processo, quer quanto ao pedido quer 
quanto à sua instrução. Em conseqüência, recomendo que, de futuro, se observe o rito determinado no Prejulgado 56.

O Recorrente não nega o fato. Pretende tão somente que a greve é 1egal, porque, por sua vez, a lei invocada pelo acórdão recorrido é inconstitucional. Aqui cabe 1embrar o ponto de vista doutrinário no sentido de que, instituída a Justiça do Trabalho, não há razão para deixar que as partes façam justiça por suas próprias mãos. Este princípio é válido, não só no âmbito da Justiça comum, mas também no campo da Justiça especializada. A existência do Poder Judiciário, tal como é constituído no regime democrático, é uma etapa na evolução humana. A Justiça do Trabalho, segundo a lição de Couture é uma solução cívilizada para a Questão Social. Como se sabe, os regimes extremistas não admitem a greve nem a existência de um poder jurisdiciona1 soberano em matéria de trabalho.

Isto pe1o simples fato de que, ali o Estado tem a propriedade dos bens e se coloca acima do direito. Tais regimes, na essência, consagram o arbítrio e eles próprios se declaram francamente "ditaduras". Mas, encarado o prob1ema do ponto de vista da evolução jurídica, lógico é que se procure uma solução dentro da 1ei. É certo, como ensinou a doutrina Tomista, que, em determinadas circunstâncias, há o direito de revolta. Cumpre, por outro lado, salientar que a Justiça do Trabalho, embora criada para decidir as questões entre empregados e empregadores, em face da chamada legislação salarial teve sua atuação limitada, de modo que não pode cumprir totalmente a relevante missão que lhe é reservada. Não se pode, portanto, dizer que o movimento grevista seja em razão da deficiência desta Justiça, mas, sim, como afirma o Recorrente, como uma consequiência da própria lei, que tolhe a livre negociação entre as partes. $\mathrm{O}$ movimento de que dão notícias estes autos tem, pois, como acentua o Recorrente, o caráter não de uma reação pura e simples contra a 1ei, mas de um meio de apelar no sentido de uma reforma da legislação salaria1. Sem condenar a legislação salaria1, instituída como barreira contra o flage1o inflacionário, e que foi inspirada no sentimento do bem público, a verdade é que, passados muitos anos nesta guerra antiinflacionária, é necessário que se proceda a uma revisão 1egislativa, cabível no âmbito dos Poderes Executivo e Legis1ativo. É aconse1hável também que se coloque a Justiça do Trabalho em condições de corresponder à sua missão social e constitucional, no mais amplo sentido, pois a esta confiança tem direito, quer pela necessidade de ordem pública quer pelo 1ongo tirocínio dos Tribunais do Trabalho, há cerca de quarenta anos funcionando em consonância com os interesses da Nação.

Não vejo inconstitucionalidade na lei $\mathrm{n}^{\circ} 4.330$, de 1964. O direito de greve é assegurado pelo artigo 165, inciso XX, da Constituição (Emenda $\mathrm{n}^{\circ} 1$ ), mas sempre, como os demais direitos ali previstos, nos termos da lei. O fato de se fazer exceção, quanto aos serviços púb1icos e atividades essenciais, não quer dizer que as demais atividades fiquem isentas do controle de uma lei, reguladora. A conclusão, segundo o preceito do artigo 165 , da Constituição, é formada de duas hipóteses: $1^{a}$, nos serviços púb1icos e nas atividades essenciais, é proibida a greve, de forma absoluta, isto é, nem mesmo regulada pode ser. $2^{\mathrm{a}}$, nas demais atividades, é admissível a greve, segundo o que dispuser a lei.

É certo que houve o movimento grevista a que se refere o processo. Certo também que não observaram os trabalhadores a formalidade 1egal. Mas não menos exato é que, como eles próprios declaram, não houve o intuito de desapreço ao Tribunal nem o desafio ao poder constituído. Não se verificou ato de violência. Enfim, não pode ser configurado o ilícito se não houve a má fé, a intenção maliciosa. No caso, está afastada essa característica. A greve teve apenas o sentido de alertar o poder público e o empresariado para uma reforma da legislação salarial e no sentido de se dar cumprimento ao preceito constituciona1 de negociação através das convenções coletivas. Verifica-se, como fator relevante, que os próprios empregadores entraram em negociação com o sindicato recorrente, e daí a convenção salarial, rea1izada em termos que não se podem classificar de catastróficos.

Por esses fundamentos, rejeito a preliminar de inconstitucionalidade da Lei $\mathrm{n}^{\circ}$ 4.330, de 1964, e, no mérito, dou provimento para reformando o v. acórdão recorrido, considerar não infringente, à citada lei, a suspensão da prestação de serviço a que se refere o presente processo e, em conseqüência, inaplicável qualquer penalidade aos traba1hadores envolvidos.

Brasília, 28 de maio de 1.979.

RAYMUNDO DE SOUZA MOURA 


\section{ANEXO 03}

Dissidio Coletivo de 1979 - Metalúrgicos de São Bernardo. Processo 48/79

Decisão do Tribunal Regional do Trabalho da $2^{\mathrm{a}}$ Região

(Os respectivos originais pertencem aos autos judiciais provenientes do Tribunal Regional do Trabalho da $2^{\text {a }}$ Região)

Processo TRT/SP - 48/79 Acórdão n 1555/79

VISTOS, relatados e discutidos estes autos de Dissídio Coletivo (Processo TRT/SP-48/79) de São Bernardo do Campo, Santo André e São Caetano do Sul, Estado de São Paulo, em que figuram como Suscitante: PROCURADORIA REGIONAL DO TRABALHO DA SEGUNDA REGIÃO e como Suscitados: SINDICATO DOS TRABALHADORES NAS INDÚSTRIAS METALÚRGICAS, MECÂNICAS E DE MATERIAL ELÉTRICO DE SÃO BERNARDO DO CAMPO, SINDICATO DOS TRABALHADORES NAS INDÚSTRIAS METALÚRGICAS, MECÂNICAS E DE MATERIAL ELÉTRICO DE SANTO ANDRÉ, SINDICATO DOS TRABALHADORES NAS INDÚSTRIAS METALÚRGICAS, MECÂNICAS E DE MATERIAL ELÉTRICO DE SÃO CAETANO DO SUL e FEDERAÇÃO DAS INDÚSTRIAS DO ESTADO DE SÃO PAULO E SINDICATO DA INDÚSTRIA DE APARELHOS ELÉTRICOS, ELETRÔNICOS E SIMILARES DO ESTADO DE SÃO PAULO e OUTROS;

ACORDAM os Juízes do Tribunal do Trabalho da Segunda região, preliminarmente, por maioria de votos, em acolher requerimento do Exmo. Sr. Procurador Regional do Trabalho e determinar a juntada aos autos do Protocolo referido da Tribuna pelo advogado das entidades patronais, vencidos os Exmos. Srs. Juízes Marcos Manus e Antonio Lamarca; por unanimidade de votos, em rejeitar a arguição de inconstitucionalidade da Lei $n^{\circ} 4.330$, de $1^{\circ}$ de junho de 1964 , formulada da Tribuna pelo advogado das entidades de trabalhadores; por maioria de votos, em considerar ilegal a greve deflagrada, vencidos os Exmos. Srs. Juízes Antonio Lamarca, Francisco Garcia Monreal Júnior, José de Barros Vieira Júnior e Aluysio Mendonça Sampaio, que entendiam não caber a apreciação da matéria em dissídio coletivo; por maioria de votos, em rejeitar a arguição de extinção do processo formulado pelo Exmo. Sr. Juiz Roberto Barretto Prado em razão da declaração de ilegalidade da greve, vencido o Exmo. Sr. Juiz Roberto Barretto Prado;

(...)

Face à paralização dos trabalhos no setor metalúrgico de São Bernardo do Campo, Santo André e São Caetano do Sul, deu-se a instauração do presente dissídio coletivo por iniciativa da Douta Procuradoria Regional do Trabalho da $2^{\mathrm{a}}$. Região, segundo ficou expressamente consignado na ata da reunião realizada perante a delegacia Regional do Trabalho, consoante fls. 149.

Inicialmente há que se ponderar que muito embora tenha sido incluída a Federação dos Trabalhadores nas Indústrias Metalúrgicas, o presente dissídio coletivo abrange, somente, aos interesses dos Sindicatos Metalúrgicos de São Bernardo do Campo, Santo André e São Caetano do Sul. Portanto, impõe-se seja refeita a autuação dada a imperfeição que apresenta.

A Entidade Patronal, por intermédio da petição de fls. $3 / 4$ dos autos, pede a manifestação desta Justiça do Trabalho sobre a legalidade, ou não, do movimento paredista ocorrido nesta data.

(...)

\section{VOTO}

Conheço do presente dissídio coletivo, de vez que atende às formalidades legais.

Estabelece o artigo $5^{\circ}$ da Lei 4.330/64 que o exercício do direito de greve deverá ser autorizado por decisão da Assembléia Geral da Entidade Sindical, que representa a categoria profissional dos associados, por $2 / 3$ em primeira convocação e por $1 / 3$ em segunda convocação, em escrutínio secreto e por maioria de votos. 
Por outro lado, o artigo $6^{\circ}$ e seus parágrafos impõem para o exercício da greve prazos para a feitura de edital de convocação dos empregados para em assembleia soberana deliberarem a respeito, cujo empregador obrigatoriamente deverá ser cientificado por escrito cinco dias antes da autorização da greve.

Dos autos nenhum elemento existe que esclareça o cumprimento de tais formalidades essenciais e necessárias à paralização dos trabalhos por iniciativa da categoria profissional.

De conseguinte, é ilegal o movimento deflagrado pelo setor profissional

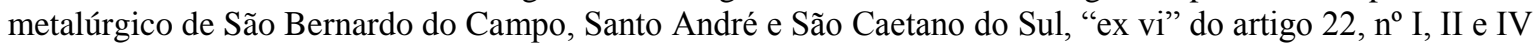
da Lei 4.330/64.

Adoto como fundamento da conclusão no sentido da ilegalidade do movimento deflagrado, as razões expendidas no Parecer da Douta Procuradoria Regional do Trabalho da $2^{\mathrm{a}}$. Região, à fls. 393, como se segue: "A greve deflagrada, data venia, não atendeu as exigências traçadas na Lei, entre elas, convocação por Edital da Assembléia voto secreto, com apuração pela Procuradoria, prova de quorum, prazos da lei, pelo que não legal é o movimento grevista eclodido, nos termos do art. 22, item I, da referida Lei".

(...)

Em face do exposto, julgo procedente em parte o dissídio coletivo e reconheço a ilegalidade do movimento deflagrado.

(...)

São Paulo, 14 de março de 1979.

NELSON VIRGÍLIO DO NASCIMENTO

MARCOS MANUS

PAULO CHAGAS FELISBERTO
PRESIDENTE

RELATOR

PROCURADOR

(CIENTE) 


\section{ANEXO 04}

Dissidio Coletivo de 1980 - Metalúrgicos de São Bernardo. Processo 58/80-A

Decisão do Tribunal Regional do Trabalho da $2^{\mathrm{a}}$ Região

(Os respectivos originais pertencem aos autos judiciais provenientes do Tribunal Regional do Trabalho da $2^{\text {a }}$ Região)

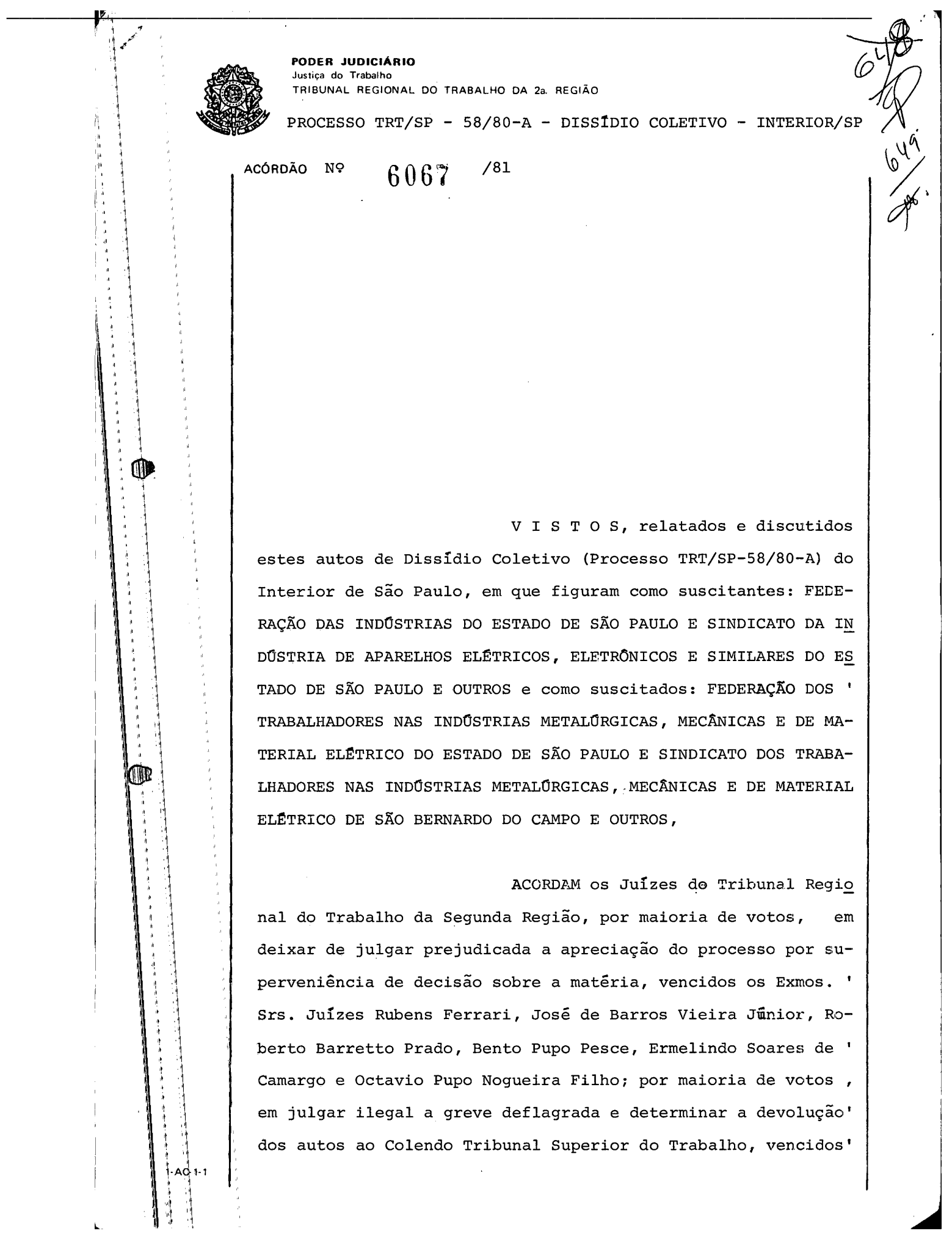




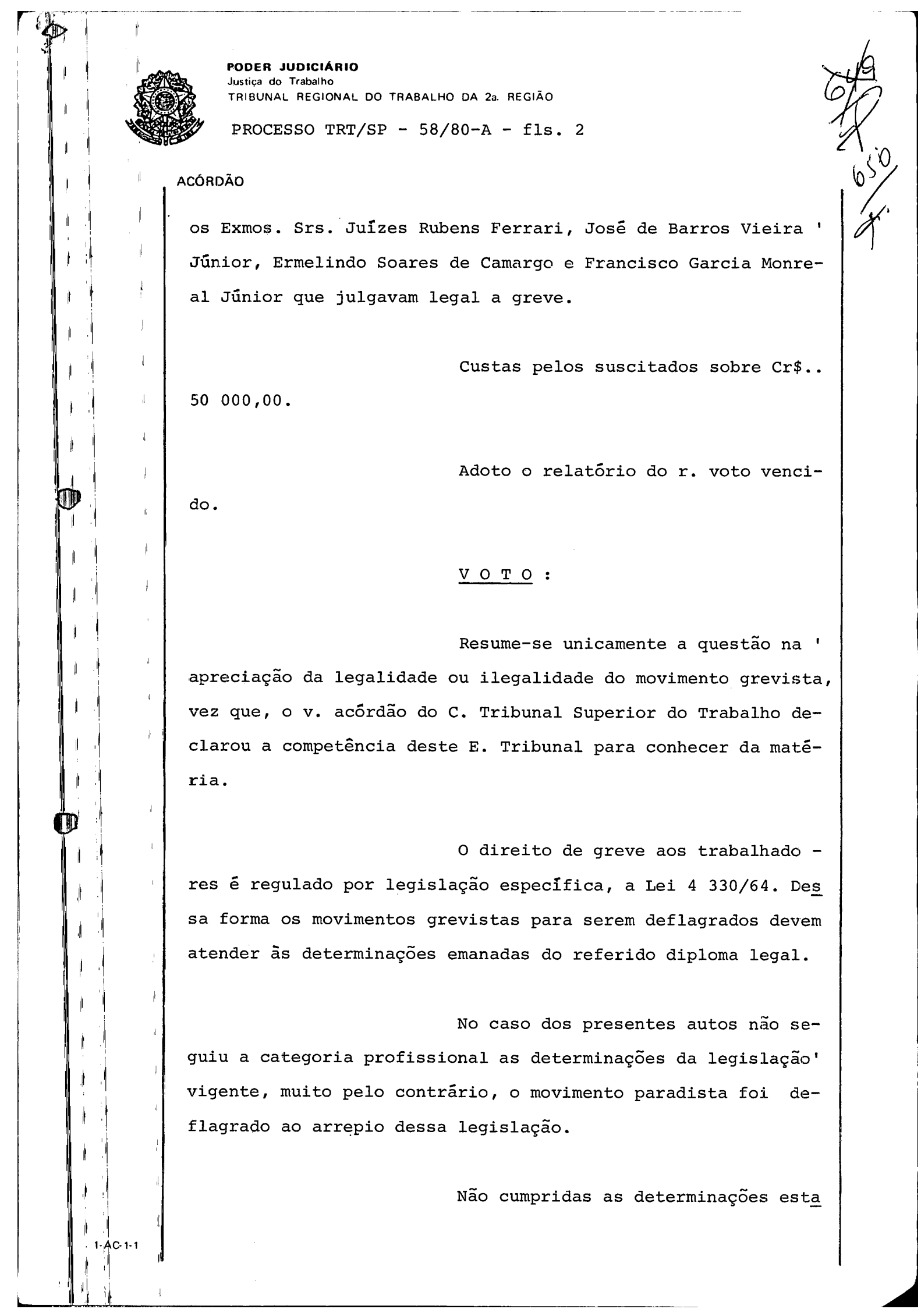




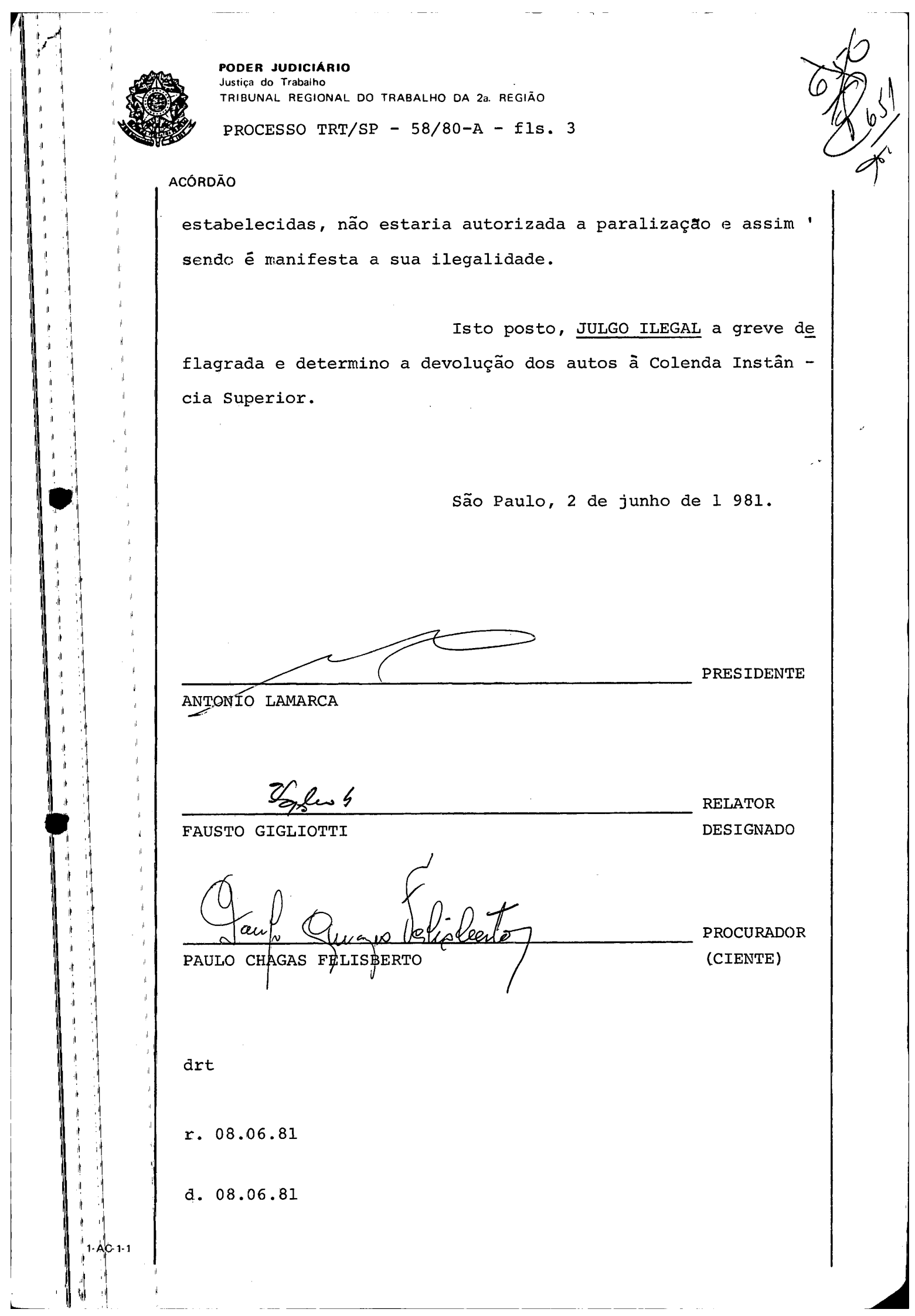




\section{PODER JUDICIARIO}

Justiça do Trabalho

TRIBUNAL REGIONAL DO TRABALHO DA 2a. REGIÃO

PROCESSO TRT/SP - 58/80-A - fls. 4

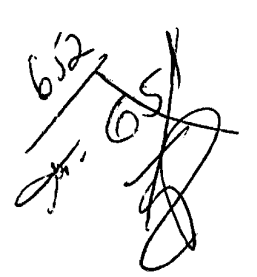

ACÓRDÃO

\section{VOTO VENCIDO DO SR. JUIZ RELATOR}

RUBENS FERRARI

Adotado o relatório constante do ' julgado de fls. 475/502, acrescento que, em grau de recurso ' ordinārio, o V. acōrdão superior de fls. 623/625, sufragando' entendimento diverso da tese vencedora nesta Instância Regional, declarou a competência dos Tribunais do Trabalho para,em dissídio coletivo, dizer da legalidade ou ilegalidade de mo vimento grevista, no respeitante ao atendimento dos pressupos tos exigidos para a sua deflagração, em consequência ao que, sem adentrar na anālise dos aspectos de mérito cuidados pelo aresto recorrido, e igualmente objeto dos recursos manifestados pelo órgão do Ministērio Público do Trabalho e pelas partes dissidentes, ordenou o retorno dos autos para o reexame ' exclusivo da matéria preliminar.

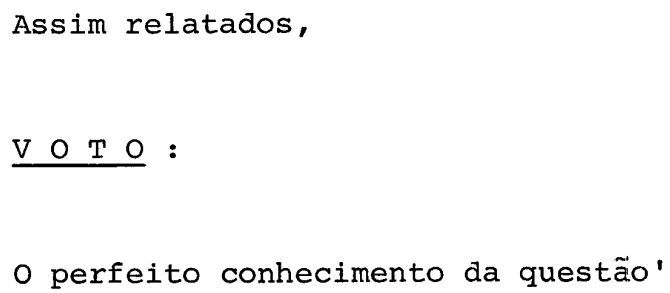
pela unanimidade dos Ilustrados Juízes deste Colegiado, associado à ampla repercussão alcançada pelas ocorrências, aqui ' objeto de reapreciação, torna prescindível a tarefa de expender informações elucidativas vestibulares, permitindo-me passar, desde logo, à análise do item alvejado pela determinação 


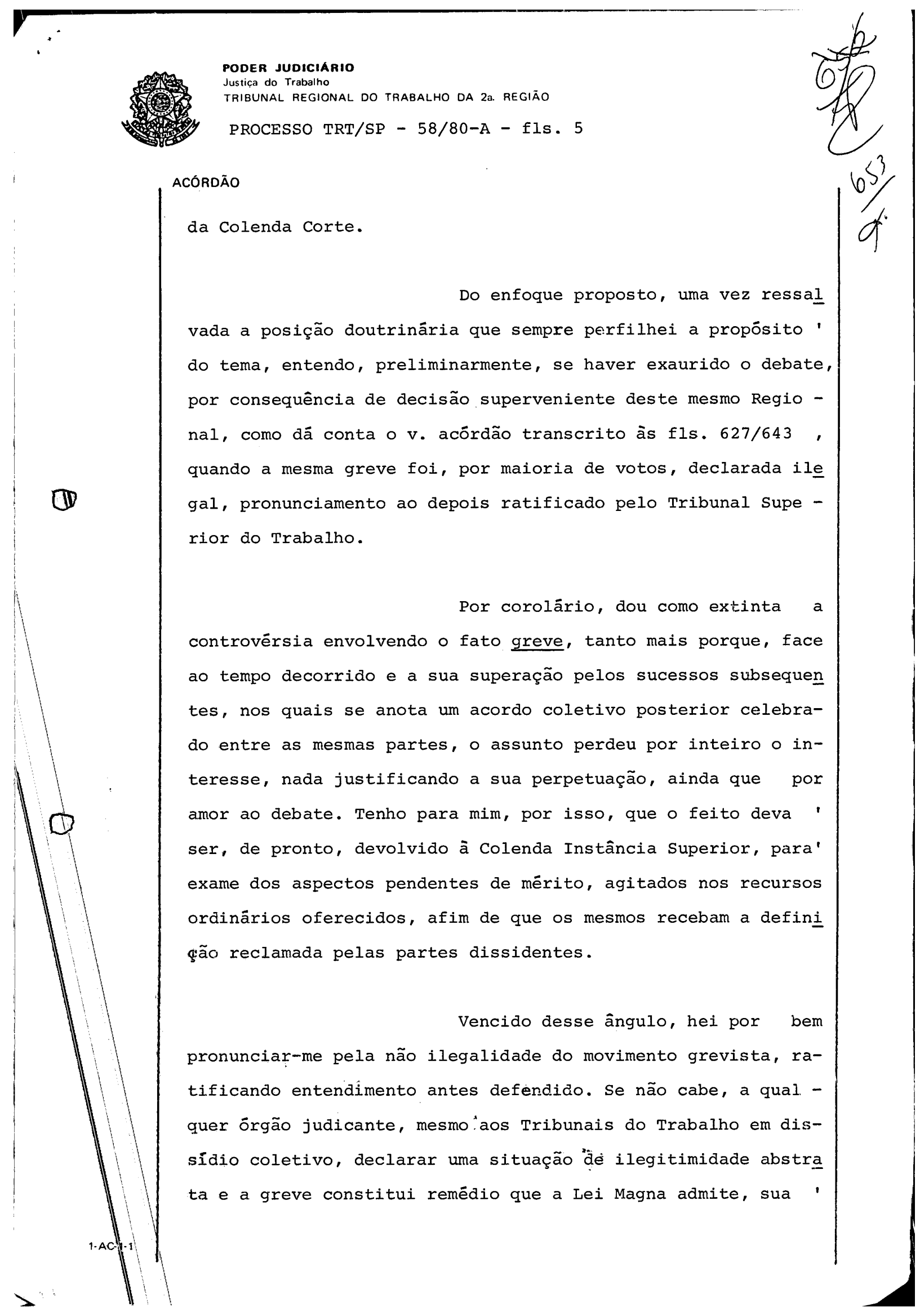




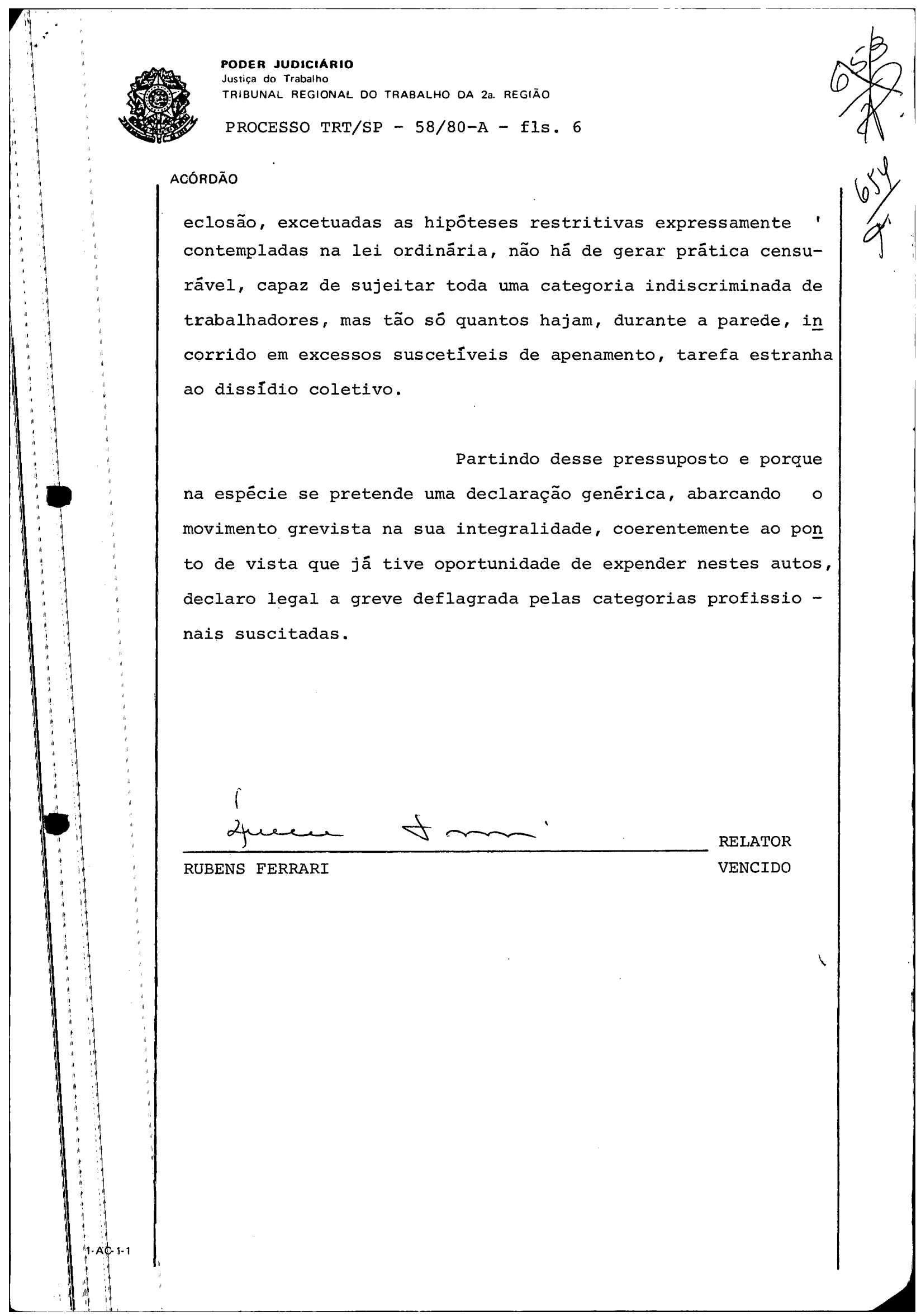




\section{ANEXO 05}

Dissidio Coletivo de 1980 - Metalúrgicos de São Bernardo. Processo TRT-RO-DC-388/80

Decisão do Tribunal Superior do Trabalho

(Os respectivos originais pertencem aos autos judiciais provenientes do Tribunal Regional do Trabalho da $2^{\text {a }}$ Região)

Processo TRT-RO-DC-388/80

Acórdão

$(\ldots)$

Recursos do Sindicato de Trabalhadores (fls.527/537 e 658/662)

\section{$1^{\circ}$ - Ilegitimidade da greve}

A questão de competência foi dirimida pelo acórdão de fls., superada assim e impossibilitado o seu reexame. Os fatos colocados pelo acórdão recorrido não são contraditados pelo recorrente e dizem com o descumprimento, na deflagração do movimento, dos pré-requisitos fixados pela Lei 4330/64 como dispõe o artigo 22, I, do mencionado diploma legal. Doutrina e jurisprudência são unânimes em reconhecer ao legisladorordinário competência para disciplinar o exercício dos direitos constitucionais. Daí não se poder falar em derrogação da Lei 4330/64 pela Constituição Federal que lhe é posterior. Se é exato que a referida lei opõe entraves formais para o início de movimentos paredistas, fixando "quorum" e prazos para a validade da declaração de greve, dificultando na prática, reconheça-se, o exercício do direito, nem por isso se poderá com jurisdicidade afirmar contrariar a lei o dispositivo constitucional assegurador do direito. Ainda que necessária a sua alteração, porque ultrapassada e vencida em eficácia pela realidade, e ser urgente o ajustamento aos fatos sociais modernos, por ora é a lei vigente. A data a partir de quandoganha eficácia a declaração de ilegalidade, para fins de incidência sobre os contratos de trabalho e demais reflexos, é matéria para eventuais dissídios individuais.

Nego provimento.

(...)

Brasilia, 09 de dezembro de 1981.

Orlando Coutinho - Relator 
ANEXO 06

Dissidio Coletivo de 1995 - Greve dos petroleiros. Processo TST-DC-177.734/95.1

Decisão do Tribunal Superior do Trabalho 
PODER JUDICIÁRIO

JUSTIÇA DO TRABALHO

TRIBUNAL SUPERIOR DO TRABALHO

PROC. N2 TST-DC-177.734/95.1 - (AC. SDC-308/95)

Relator : MIN. URSULINO SANTOS

Suscitante: PETRÓLEO BRASILEIRO S/A - PETROBRÁS

Advogado : Dr. Ruy Jorge Caldas Pereira

Suscitados: FEDERAÇÃO ÚNICA DOS PETROLEIROS, SINDICATO DOS TRABALHADORES NA INDÚSTRIA DE DESTILAÇÃO E REFINAÇÃo DE PETRÓLEO DE CUBATÃO, SANTOS E SÃO SEBASTIÃO, SINDICATO DOS TRABALHADORES NA INDÚSTRIA DA EXTRAÇÃO DO PETRÓLEO NOS ESTADOS DE ALAGOAS E SERGIPE, SINDICATO DOS TRABALHADORES NA INDÚSTRIA DA DESTILAÇÃO E REFINAÇÃO DO PETRÓLEO DE PORTO ALEGRE, CANOAS, OSÓRIO E TRAMANDAÍ - RS, SINDICATO DOS TRABALHADORES NA INDÚSTRIA DA ESTRAÇÃO, ESTOCAGEM E TRANSFERÊNCIA DO PETRÓLEO, SEUS DERIVADOS E GÁS NATURAL DO ESTADO DA BAHIA, SINDICATO DOS PETROLEIROS DO ESTADO DA BAHIA, SINDICATO DOS TRABALHADORES NA INDÚSTRIA DA DESTILAÇÃo E REFINAÇÃo DO PETRÓLEO DE CAMPINAS E PAULÍNEA, SINDICATO DOS TRABALHADORES NA INDÚSTRIA DE DESTILAÇÃO E REFINAÇÃO DE PETRÓLEO DE DUQUE DE CAXIAS, SINDICATO DOS TRABALHADORES NA INDÚSTRIA DA DESTILAÇÃO E REFINAÇ̃̃ DE PETRÓLEO NO ESTADO DO CEARÁ, SINDICATO DOS TRABALHADORES NA INDÚSTRIA DA DESTILAÇÃO E REFINAÇÃO DE PETRÓLEO NO ESTADO DO AMAZONAS, SINDICATO DOS TRABALHADORES NA INDÚSTRIA DA DESTILAÇÃO DE PETRÓLEO DE MAUÁ, SINDICATO DOS TRABALHADORES NA INDÚSTRIA DA DESTILAÇÃO E REFINAÇÃO DE PETRÓLEO DE MINAS GERAIS, SINDICATO DOS TRABALHADORES NA INDÚSTRIA DA EXTRAÇÃO DO PETRÓLEO NOS ESTADOS DO PARÁ, AMAZONAS, MARANHÃO E AMAPÁ, SINDICATO DOS TRABALHADORES NAS INDÚSTRIAS DE REFINAÇÃ́, DESTILAÇÃO, EXPLORAÇÃO E PRODUÇÃO DE PETRÓLEO NOS ESTADOS DO PARANÁ E SANTA CATARINA, SINDICATO DOS TRABALHADORES NA INDÚSTRIA DA DESTILACC̃̃O E REFINAÇÃO DO PETRÓLEO NO ESTADO DO RIO DE JANEIRO, SINDICATO DOS TRABALHADORES NA INDÚSTRIA DA DESTILAÇÃO E REFINAÇÃO DO PETRÓLEO NO ESTADO DO RIO GRANDE DO NORTE, SINDICATO DOS TRABALHADORES NA INDÚSTRIA DA DESTILAÇÃO E REFINAÇÃO DO PETRÓLEO DE SÃO JOSÉ DOS CAMPOS, SINDICATO DOS TRABALHADORES NA INDÚSTRIA DA DESTILAÇÃO E REFINAÇÃO DO PETRÓLEO DE BARUERI E GUARULHOS, SÃO CAETANO DO SUL E SÃO PAULO, SINDICATO DOS TRABALHADORES NA INDÚSTRIA DE EXPLORAÇÃO, PERFURAÇÃO, EXTRAÇÂO E PRODUÇÃO DE PETRÓLEO NOS MUNICÍPIOS DE SÃO MATEUS, LINHARES, CONCEIÇÃO DA BARRA E JAGUARÉ NO ESTADO DO ESPIRITO SANTO, SINDICATO DOS TRABALHADORES DA INDÚSTRIA DE PETRÓLEO DO ESTADO DE PERNAMBUCO, SINDICATO DOS TRABALHADORES NAS INDÚSTRIAS E EMPRESAS PETROQUIMICAS, QUÍMICAS, PLÁSTICAS E AFINS BAHIA E SINDICATO DOS TRABALHAROES DA INDÚSTRIA DE PRODUTOS PETROQUÍMICOS, PLÁSTICOS E SIMILARES DO ESTADO DE SERGIPE

Advogado : Dr. Carlos Alberto Boechast Rangel

EMRNTA: DISSIDIO COLETIVO - GREVE NA VIGÊNCIA DE SENTENÇA NORMATIVA DEFLAGRADA COM OBJETIVO DE EXIGIR CUMPRIMENTO DE ACORDO POSTERIOR INAPLICABILIDADE DO INCISO I DO PARÁGRAFO ÚNICO DO ART. 14 DA LEI 7.783/89 - PARALISAÇÃo ABUSIVA. Se a greve é deflagrada na vigência de sentença normativa, com o objetivo de exigir o cumprimento de cláusula ou condição prevista em acordo posterior, o qual não possui as características próprias de um convênio coletivo de trabalho, por faltarThe os requisitos mínimos que a lei exige para a sua celebração, não cabe a aplicação da excludente contida no inciso I do parágrafo único do art. 14 da Lei $n^{2} 7.783 / 89$ (Lei de Greve). Dissídio coletivo julgado procedente para declarar abusiva a paralisação.

RELATÓRIO: Cuidam os autos de dissídio coletivo instaurado pela Petróleo Brasileiro S/A - PETROBRÁS, contra a Federação Única dos Petroleiros e 21 Sindicatos Profissionais elencados às fls. 02/05, tendo em vista a greve ocorrida nas suas unidades de produção. 
PROC. N2 TST-DC-177.734/95.1 - (AC. SDC-308/95)

Alega a Suscitante; em sintese, que- a greve-foi deflagrada na vigência de norma coletiva e desobedeceu o rito previsto na Lei ne $7.783 / 89$, inclusive porque, tratando-se de empresa que desenvolve atividade essencial, não foi garantida a prestação de serviços necessários ao atendimento das necessidades inadiáveis da sociedade. Conclui pedindo que a greve seja declarada abusiva, com a determinação de retorno imediato ao trabalho e a fixação de multa no valor de $\mathrm{R} \$$ $100.000,00$, por dia, na hipótese de descumprimento de tal determinação (fls. 02/07)

Ao designar a audiência de conciliação, o Presidente desta corte determinou que fosse mantido em atividade o minimo de $30 \%$ de trabalhadores, com o fito de preservar a população das consequiências negativas da falta de combustível e gás gerada pela greve (fls. $52 / 53)$.

Em contestação, a suscitada argúi a preliminar de ilegitimidade passiva em relação ao Sindipetro Pernambuco, afirmando que a categoria profissional em sua base não participa do movimento paredista. Sustenta que a greve tem razão no descumprimento pela Suscitante do acordo firmado com o Governo Federal e de posterior acordo havido com a própria Petrobrás, assim como na inobservância da sentença normativa proferida por este Tribunal superior no DC-131.024/94. Diz que a greve tem sustentação no inciso $I$, do $\S 1 \%$, do art. 14 da Lei $n^{2}$ $7.783 / 89$, que foram cumpridas as exigências dos arts. 13 e $4^{2}$, da referida Lei, sendo infundada a alegação da suscitante no sentido de que o Sindipetro Manaus não comunicou a greve com 72 horas de antecedência. Esclarece que em Minas Gerais a Empresa não liberou os trabalhadores do turno que findava às 16 horas e, em contrapartida, os empregados do turno seguinte ficaram aquardando a troca, que não foi realizada. Afirma que está cumprindo a determinação contida no despacho de fls. $52 / 53$ e finaliza pedindo a improcedência do dissídio, declarando-se a legalidade da greve e a procedência das reivindicações dos trabalhadores que são as seguintes: "1 - Cumprimento do item 3 do Protocolo assinado em 25/11/94 - "A PETROBRÁS adequará a atual relação de interniveis, no prazo de 20 dias, visando a promover eventuais ajustes". Este acordo complementar ao que dispóe a cláusula 105 da Sentença Normativa do TST;

2 - a reposicão das perdas salariais pelo ICV-DIEESE estimativa de set/94 e abril/95 $(26,63 \%)$

3 - a reintegração dos demitidos por participação em movimentos reivindicatórios

4 - cumprimento da Lei de Anistia aos trabalhadores demitidos durante o governo collor, com a conseqüente readmissão imediata; 5 - recomposição dos efetivos mínimos, com uma política de contratações antecipadas, através de concursos públicos

6 - ao pagamento dos passivos trabalhistas:

7 - a suspensão imediata da implantação do GDP (Gerenciamento de Desempenho de Pessoal), das "flexibilização de normas" e implementação das multifunções (polivalência)" (fls. 87). A audiência de conciliação e instrução transcorreu nos termos descritos na ata de fls. $129 / 138$, a qual registra a impossibilidade de acordo, a concessão de 03 dias para a juntada de documentos por parte dos litigantes, o depoimento dos prepostos das partes, as alegações finais e a manifestação do Ministério Público do Trabalho, cujo parecer conclui no sentido da declaração da abusividade da greve e atendimento parcial das reivindicações dos trabalhadores, para que a empresa seja obrigada a cumprir o acordo que firmou em 25 de novembro de 1994.

Ao final da tarde de ontem, as partes peticionaram a juntada de diversos documentos. A Petrobrás o de fls. 141/143, intitulado "Estudo de Novos Interniveis para Empregados Terrestres". A Federação suscitada juntou seu estatuto, procurações, editais, atas de assembléias dos sindicatos filiados, listas de presença, notificações 
PROC. N2 TST-DC-177.734/95.1 - (AC. SDC-308/95)

à empresa referentes à greve, o protocolo firmado com a Suscitante, os termos de "entendimento" e de acordo estabelecidos com o Governo Federal e outros (fls. 146/343).

Cumpre registrar, ademais, que as partes tiveram ciência do teor dos documentos retro referidos. Quanto a eles nada opôs a Petrobrás. Já a Suscitada pediu o desentranhamento daqueles de fls. $141 / 143$.

É o relatório.

$\underline{\mathrm{v}} \underline{\mathrm{O}} \underline{\mathbf{T}} \underline{\mathrm{O}}$

DO DESENTRANHAMENTO DOS DOCUMENTOS DE FLS. 141/143

o desentranhamento do chamado "Estudo de Novos Interníveis para Empregados Terrestres" é requerido por entender a Federação suscitada que ele é apenas uma tabela e não o estudo propriamente dito, efetivado pela Empresa e remetido ao Ministério das Minas e Energia, que é o que deveria ter vindo aos autos, segundo a determinação da Presidência da Corte, contida na ata da audiência de conciliação e instrução.

Embora não seja o estudo pormenorizado da situação de interníveis, é, sem dúvida, o seu resultado o que interessa para a promoção dos ajustes pretendidos pelos trabalhadores. $\dot{E}$ bom que se frise que a Suscitada não impugna o documento pelo que nele se contém, ou the lança qualquer pecha que o vicie. Indefiro o desentranhamento.

DA ILEGITMIDADE DE PARTE PASSIVA DO SINDIPETRO-PE

Alega-se que o Sindipetro-Pe não deliberou pela participação no movimento grevista, sendo, por isso, parte ilegitima para figurar no pólo passivo da demanda.

o presente dissídio coletivo foi suscitado perante este Tribunal Superior não só em razão do movimento grevista ter extrapolado a jurisdição de outros TRTs, como também porque a empresa suscitante possui quadro de carreira organizado em âmbito nacional. Deste modo, a decísão a ser tomada afeta a categoria profissional em todo o país, mormente em relação às reivindicações dos trabalhadores, as quais, se atendidas, serão aplicadas, inclusive, nas bases dos sindicatos que não aderiram à parede, sob pena de quebra da isonomia buscada pela adoção do quadro, o que legitima a participação na lide do sindipetro-Pe.

Rejeito a preliminar.

PRRLTMTNAR DE ILEGTTIMIDADE "AD CAUSAM" DA FEDERAÇ̃̃o ÚNICA DOS PETROLEIROS, ARGÜIDA DE OFÍCIO PELO SR. MINISTRO ERMES PEDRASSANI A argüição tem por fundamento o fato de a Federação Única
dos Petroleiros não reunir as caracteristicas de uma entidade sindical, principalmente porque o registro competente perante o Ministério do Trabalho ainda se processa, como informou da Tribuna o seu ilustre advogado. E, estando em processamento o necessário registro, ela ainda não integra o sistema sindical brasileiro.

Juntamente com outros Ministros acompanhei tal entendimento, para excluir da lide a Federação suscitada. Todavia, o Tribunal, por sua maioria, rejeitou a preliminar, calcado principalmente no exercício de fato, por esta Federação, da representatividade dos sindicatos da categoria profissional, atestado pelo reconhecimento desta representatividade pela própria suscitante, que a elencou entre os suscitados e que com ela negociou.

DA ABUSIVIDADE DA GREVE

Segundo a Suscitante, o movimento grevista é abusivo por não observar os mandamentos previstos nos arts. $9^{\circ}, 11,13$ e 14 , da Lei $n^{\circ}$ 
PROC. N2 TST-DC-177.734/95.1 - (AC. SDC-308/95)

$7.783 / 89$, salientando que sua deflagração se deu em plena vigência de norma coletiva.

Em relação ao prímeiro preceito, não há nos autos prova de que os grevistas tenham deixado de "assegurar os serviços cuja paralisação resultem em prejuízo irreparável, pela deterioração irreversível de bens, máquinas e equipamentos, bem como manutenção daqueles essenciais à retomada das atividades da empresa quando da cessação do movimento".

Também é fato público e -notório que a população teve ciência da paralisação da categoria com antecedência superior a 72 horas, pela ampla divulgação dada pelos veículos de comunicação (jornais e emissoras de rádio e televisão), sendo que a empresa foi diretamente informada, por escrito, por diversos sindicatos e pela Federação dos trabaIhadores (fls. 31/49), mostrando-se irrelevante a alegação empresarial de que o sindipetro-Pe deixou de fazer a comunicação e o do estado do Amazonas não a fez no prazo legal, porquanto na comunicação enviada pela Federação obreira consta que todos os sindicatos haviam deliberado paralisar a produção ( $\mathrm{fls}$. $35 / 36$ ).

Todavia, admitem os Suscitados em sua contestação que em Minas Gerais não foi realizada a troca do pessoal do turno que findava às 16 horas do dia anterior ao marcado para o início da greve, sob a alegação de que os trabalhadores que iriam assumir ficaram aguardando a saída daqueles cuja jornada se esgotara e que, segundo afirmam, não foram liberados pela empresa. o argumento é, no mínimo, ingênuo. É óbvio que, numa refinaria de petróleo, o processo produtivo é complexo e exige que a troca do pessoal nele envolvido ocorra sem interrupção do trabalho. Logo, os trabalhadores do turno terminal só poderiam ser dispensados após a apresentação do pessoal que iria assumir. A atitude de não realizar a troca de pessoal corresponde a uma ação coordenada de paralisação do trabalho, realizada antes da data marcada para o início da greve.

Em relação ao atendimento das necessidades inadiáveis da comunidade, há fortes evidências de que a prestação dos serviços para tal indispensáveis não estão sendo garantidos, seja pelo impasse nas negociações entre a empresa $e$ os trabalhadores sobre 0 pessoal necessário, seja pelo descumprimento puro e simples das determinações contidas no despacho de fls. 52/53, do $\mathrm{Sr}$. Ministro Presidente deste Tribunal, que estabeleceu a obrigatoriedade de permanência em serviço de pessoal em número correspondente a $30 \%$ dos efetivos de cada grupo de trabalhadores envolvidos nas atividades de operação, de apoio operacional e de apoio administrativo, conforme se verifica pelos documentos produzidos pelo Ministério Público do Trabalho, constantes de fls. $121 / 122,123 / 124,125$ e 126. É oportuno lembrar que, em momento algum, as partes se opuseram ao despacho de fls. 52/53. E a simples emissão da ordem emanada da Presidência da Corte por si só revela a desobediência ao art. 11 da Lei de Greve, pois que somente este fato autoriza a prática do ato judicial referido, como bem já demonstrou o Ministro orlando Teixeira da Costa em anterior julgamento de dissídio coletivo envolvendo as mesmas partes.

Por outro lado, a eclosão da greve ocorreu na vigência da sentença normativa proferida por este Tribunal Superior nos autos do processo DC-131.024/94. Os suscitados invocam a excludente contida no inciso I, do parágrafo único, do art. 14 da Lei de Greve, apontando o descumprimento de tal sentença pela empresa, como uma das causas da parede, sendo que a cláusula que se diz descumprida tem $\circ$ seguinte teor: "Até 31.08 .95 , a Companhia analisará a atual relação internível das escalas salariais, visando à possibilidade de promover eventuais adequações de caráter exclusivamente técnico, vinculadas à manutenção do equilíbrio remuneratório interno" (fls. 26). Ora, além de nâo haver ainda expirado prazo para o cumprimento da cláusula, esta não obriga a empresa a implementar qualquer alteração em relação aos interníveis salariais, mas apenas aventa com tal possibilidade. 
PROC. N2 TST-DC-177.734/95.1 - (AC. SDC-308/95)

Também indicam os Suscitados como justificativa para a greve, que a empresa não honrou os acordos firmados com o Governo Federal em 05 de outubro e 10 de novembro de 1994 e o posterior, este estabelecido com a própria Suscitante em 25 do mesmo mês e ano. Entretanto, o descumprimento de tais acordos pela Petrobrás não obsta a incidência do art. 14 da Lei $n^{2} 7.783 / 89$. É que a Petrobrás não figura como parte nos dois primeiros, sendo que, dentre estes, o que tem 0 título de "TERMO DE ENTENDIMENTO DO GOVERNO FEDERAL COM OS PETROLEIROS/CUT", não está sequer assinado por qualquer das partes (fls. 147 e $148 / 152)$. Mesmo aquele firmado pela . Petrobrás não é apto para propiciar a aplicação do preceito legal que os Suscitados apontaram, pois não veste o figurino adequado. Para emprestar-lhe o caráter de um acordo coletivo de trabalho e exeqüibilidade, falta-lhe os requisitos mínimos que a lei exige para a celebração, como a deliberação da assembléia da entidade sindical convenente, realizada com 0 comparecimento dos interessados e observância do "quorum" específico, as cláusulas obrigatórias e o depósito no competente órgão do Ministério do Trabalho.

Por outro lado, não vieram aos autos os estatutos dos sindicatos grevistas, documentos indispensáveis para comprovar que foram observadas as formalidades estatutárias de convocação e "quorum"para a deflagração do movimento. E não havendo a comprovação do cumprimento das formalidades estatutárias não se pode afirmar o regular exercício do direito de greve.

Por todo o exposto, declaro abusivo o movimento grevista e autorizo o desconto dos dias em que houve paralisação do trabalho, com a devida repercussão nos contratos individuais, determinando o imediato retorno dos trabalhadores à atividade, cominando multa diária de RS $100.000,00$ (cem mil reais), para cada entidade sindical, na hipótese de manutençẫo da greve após às 12:00 horas de amanhã, día 10 de maio de 1995.

DAS REIVINDICAÇÕES DA CATEGORIA PROFISSIONAL

Não cabe determinar a implementação do acordo firmado pelas partes em $25 / 11 / 94$, por este não se identificar com a forma legal de um convênio coletivo de trabalho.

As demais reivindicações importam em revisão da sentença normativa que vige há menos de um ano, esbarrando, in limine, no art. $873 \mathrm{da}$ CLT. profissional.

Julgo improcedentes todas as reivindicações da categoria É o meu voto.

\section{ISTO POSTO}

ACORDAM os Ministros da Seção Especializada em Dissídios Coletivos do Tribunal Superior do Trabalho, I- Por maioria, rejeitar a preliminar de desentranhamento do documento de fls. 140/144, vencido o Excelentíssimo Senhor Ministro Thaumaturgo Cortizo. II- À unanimidade, rejeitar a preliminar de exclusão da lide do sindicato dos Trabalhadores da Indústria de Petróleo do Estado de Pernambuco. III- Por maioria, rejeitar a preliminar argüida pelo Excelentíssimo Senhor Ministro Ermes Pedro Pedrassani de ilegitimidade "ad causam" da Federação única dos Petroleiros, vencidos os Excelentíssimos Senhores Ministros Ermes Pedro Pedrassani, Ursulino Santos, José Luiz Vasconcellos e Armando de Brito. IV- DA GREVE: Por maioria, declarar abusiva a greve, desobrigando a Empresa do pagamento dos salários dos dias em que houve paraIisação do trabalho, com a devida repercussão dos contratos individuais, e determinando o imediato retorno dos trabalhadores à atividade, cominando multa diária de $\mathrm{R} \$ 100.000,00$ (cem mil reais) para cada entidade sindical, na hipótese de manutenção da greve após às 12:00 
PROC. N2 TST-DC-177.734/95.1 - (AC. SDC-308/95)

horas de amanhã, dia 10 de maio de 1995, vencido o- Excelentíssimo Senhor Ministro Thaumaturgo Cortizo. V- DAS REIVINDICAÇõES DA CATEGoRIA PROFISSIONAL: Por maioria, julgar improcedente todas as reivindicações da categoria profissional, vencidos os Excelentíssimos Senhores Ministros Thaumaturgo Cortizo e José Ajuricaba, e o Excelentíssimo Senhor Juiz Convocado Mauro Viola, que determinavam à Empresa que cumprisse o protocolo firmado em 25 de novembro de 1994 . Juntarão voto convergente os Excelentíssimos Senhores Ministros Almir Pazzianotto e Armando de Brito.

Brasília, 09 de maio de 1995.

JOSÉ AJURICABA - Presidente

URSULINO SANTOS - Relator

Ciente: JOÃO PEDRO FERRAZ DOS PASSOS - Procurador-Geral do Trabalho

US/HB/psa 
PODER JUDICIÁRIO

JUSTIÇA DO TRABALHO

TRIBUNAL SUPERIOR DO TRABALHO

PROCESSO Ne TST-DC-177734/95.1

\section{Voto Convergente}

A Petróleo Brasileiro S.A. - PETROBRÁs, foi criada pela Lei $n^{\circ} 2.004$, de 3 de outubro de 1993, que dispôs sobre a política nacional do petróleo e definiu as atribuições do Conselho Nacional de Petrôleo, instituindo a sociedade por ações petróleo Brasileiro Sociedade Anônima.

Nos antecedentes da Lei $n^{\circ} 2.004 / 53$, além de um sem número de campanhas populares, movimentações sindicais, conferências, artigos publicados, perseguições, prisões e mortes, tivemos dois DecretosLeis. O de número 395, de 29 de abril de 1938, declarando de utilidade pública e regulando a importação, exportação, transporte, distribuiçâo e comércio de petróleo bruto e seus derivados, no territóxio nacional, a indústria da refinação de petróleo importado ou produzido no país, e - de número 538, de 7 de julho de 1938, organizando o Conselho Nacional de Petróleo e definindo as suas atribuições.

A Lei $n^{\circ} 2.004 / 53$, em seu artigo 19, $\$ 1^{\circ}$, estabelece que "A Sociedade será dirigida por um Conselho de Administração, com funções deliberativas, e uma Diretoria Executiva". O referido Conselho de Administração será constituído de um Presidente nomeado pelo Presidente da República, demissivel ad nutum, com direito de veto sobre as decisões do próprio Conselho e da Diretoria Executiva. Também terá de 3 a 6 Diretores nomeados pelo presidente da República, com mandato de 3 anos, além de conselheiros eleitos pelas pessoas jurídicas de direito público, com exceção da União, em número máximo de 3 com mandato de 3 anos e Conselheiros eleitos pelas pessoas jurídicas de direito privado, em número máximo de 2 e mandato de 3 anos. 
PODER JUDICIÁRIO

JUSTIÇA DO TRABALHO

TRIBUNAL SUPERIOR DO TRABALHO

PROCESSO N TST-DC-177734/95.1

A Diretoria Executiva, a teor do $\S 3^{\circ}$ do mesmo artigo 19, "compor-se-á de Presidente e dos diretores nomeados pelo Presidente da República".

A Lei da Petrobrás prevê a existência dos seus Estatutos, encontrando-se em vigor aqueles aprovados pelo Decreto de 30 de setembro de 1991, com as alterações posteriores, os quais dispõem sobre o Conselho de Administração e a Diretoria Executiva, fixando $\circ$ artigo 40 que esse Conselho "tem funções deliberativas, cabendo-lhe, precipuamente, fixar os objetivos e políticas empresariais". Compete ao Consetho deliberar, entre outras matérias, sobre "planos de classificação e avaliação de cargos, de desenvolvimento de recursos humanos, de remuneração e vantagens, critérios de participação nos lucros e normas gerais sobre administração de pessoal" (artigo 42, inciso IX).

A Diretoria Executiva, segundo o disposto pelo artigo 46 "é o órgão de Administração Geral da Companhia, cabendo-1he, precipuamente, fazer cumprir as diretrizes fundamentais e as normas gerais aprovadas pelo Conselho de Administração, dentro dos objetivos e políticas empresariais por ele fixados".

Determina-se, também, no artigo 51, inciso $I$, competir ao Presidente "representar a PETROBRÁS, em juízo ou fora dele", perante as subsidiárias e coligadas, os acionistas e $\circ$ público em geral, podendo nomear procuradores ou prepostos". É ainda ao Presidente da Diretoria Executiva que incube "assinar atos, contratos e convênios e, juntamente com outro Diretor, movimentar os dinheiros da Companhia, 
PODER JUDICIÁRIO

JUSTIÇA DO TRABALHO

TRIBUNAL SUPERIOR DO TRABALHO

PROCESSO N2 TST-DC-177734/95.1

podendo tais faculdades serem outorgadas, por mandato, aos demais Diretores, a empregados ou procuradores" (art. 57, inciso X).

Bastam essas informações, para se compreender de pronto que, embora o Presidente da República goze da prerrogativa de nomear e demitir o presidente da Petrobrâs, não tem ele, nem o seu Ministro de Estado, competência para agir em nome da petrobrás, assinando acordo coletivo de trabalho, alteração de acordo coletivo ou de sentença normativa. Esses impedimentos parecem-me óbvios, pois sendo a Petrobrás uma sociedade de economia mista, de capital aberto, com forte participação acionária de pessoas físicas e jurídicas de direito privado, não compete ao presidente da República interferix na sua vida administrativa, nos seus negócios, nas suas atividades, a não ser na forma e pela maneira previstas em lei. Pelas mesmas razões, não pode o Sr. Presidente emitir cheque, fazer compras ou efetuar vendas em nome e por conta da empresa.

A defesa, às fl. 80/88, alega que a Petrobrás descumpriu não apenas um, mas três acordos realizados com os sindicatos. O primeiro, que denominarei de "encontro de Juiz de Fora", pois ocorreu nessa tradicional cidade mineira, tendo como protagonistas o então Presidente da República Itamar Franco, vários Ministros de Estado e representantes sindicais. O documento relativo a este encontro se acha a fl. 147, não contém nenhuma assinatura e as suas 7 cláusulas, à exceção da $7^{2}$, referente a dias parados em conseqüência da greve de setembro do ano passado, estabelecendo sua forma de pagamento, não podem ser consideradas como integrando acordo coletivo de natureza salarial. Pelo contrário, ali se diz, no item 1, que aquele movimento grevista deveria cessar imediatamente, com absoluto acatamento a todas as determinações do Tribunal superior do Trabalho "em seus julgados pertinentes à questão". 
PODER JUDICIÁRIO

JUSTIÇA DO TRABALHO

TRIBUNAL SUPERIOR DO TRABALHO

PROCESSO N TST-DC-177734/95.1

o segundo suposto acordo seria o assinado pelo então Ministro das Minas e Energia, Dr. Delcídio Gomes. Bem mais extenso que o anterior, contendo 33 cláusulas, trata de vários assuntos, entre os quais a anistia a empregados demitidos no passado. Evidentemente, esse documento não vincula a Petrobrás. As competências do Ministro de Estado acham-se delimitadas pelo art. 87, da Constituição Federal, e o situam como auxiliar direto do Presidente da República. Nem a Constituição, nem a Lei 2.004/53, nem os Estatutos da Petrobrás, concedem a Ministro de Estado prerrogativas para assumir obrigações em nome das sociedades anônimas de economia mista.

O terceiro acordo é aquele existente à fl. I46, subscrito pela Federação Única dos Petroleiros e pelo Superintendente Adjunto.do Serviço de Recursos Humanos da Petrobrás. Denominado Protocolo prevê - prosseguimento das conversações entre a empresa e a Federação Única, visando à assinatura de um novo Acordo Coletivo a vigir até agosto de 1995; a manutenção das cláusulas do Acordo Coletivo que vigorou entre 1993/94; a adequação da atual relação interníveis, no prazo de 20 dias, visando a promover eventuais reajustes, condicionando-se sua aplicação à suspensão imediata da greve e retorno imediato ao trabalho e desistência, pela Petrobrás, do dissídio coletivo TST-DC 146.945/94.3, "em face do encerramento do movimento grevista neste ato". O documento foi lavrado em 25 de novembro do ano passado.

Ocorre que, apesar das suas boas intenções, o subscritor desse Protocolo não detinha poderes para realizar essa negociação, nem ela foi ratificada posteriormente pela Presidência da Petrobrás. Nos autos do processo não encontrei documento que me leve a concluir em outra direção. 
PODER JUDICIÁRIO

JUSTIÇA DO TRABALHO

TRIBUNAL SUPERIOR DO TRABALHO

PROCESSO $N^{2}$ TST-DC-177734/95.1

Como antes deixei demonstrado, segundo as disposições legais e estatutárias que regem a Petrobrás, exatamente para que a empresa não seja vítima de manobras contrárias aos șeus interesses e aos interesses dos seus acionistas, apenas o Presidente da Diretoria executiva pode representá-la em juIzo ou fora dele, embora se ache autorizado a delegar poderes, através de mandato, aos demais Diretores, a empregados e a procuradores (art. 57, XI).

Inexistindo o suposto acordo celebrado com o presidente da República Dr. Itamar Franco, sendo destituído de qualquer validade o documento assinado pelo então Ministro das Minas e Energia, e não havendo sido ratificado o protocolo que contém o autógrafo do Superintendente Adjunto, devo concluir que a Petrobrás, em momento nenhum, se obrigou ou foi obrigada validamente a reajustar, recalcular salários ou a praticar novos interníveis.

As demais reivindicações (fl. 87) não merecem melhor sorte. A reposição de perdas salariais pelo ICV-DIEESE, estimadas em $26,63 \%$, não recebe amparo na legislação salarial vigente, havendo, ainda, Norma Coletiva em vigor; a reintegração dos demitidos por participação em movimentos reivindicatórios é tema a ser tratado diretamente pelas partes, ou através de reclamações individuais, não encontrando abrigo na esfera de competência normativa deste Tribunal. o cumprimento da Lei da Anistia é outro assunto alheio à jurisdição deste Tribunal; a recomposição dos efetivos mínimos, igualmente, não pode ser objeto de decisão desta $S D C$ e a suspensão imediata da implantação do Gerenciamento de Desempenho de Pessoal, das flexibilizações e da implementação das multifunções padece da mesma dificuldade. Restaria a questão 
PODER JUDICIÁRIO

JUSTIÇA DO TRABALHO

TRIBUNAL SUPERIOR DO TRABALHO

PROCESSO N TST-DC-177734/95.1

referente ao pagamento dos passivos trabalhistas, mas não foi dado ao Tribunal saber a que passivos estão os sindicatos se referindo; se dívidas já apuradas em reclamações individuais, ou se a referência é feita a meras pretensões não definitivamente caracterizadas.

Impõe-se concluir que a Federação e os Sindicatos por ela coordenados não apreenderam perfeitamente a situação criada após o julgamento do Dissídio Coletivo TST-DC 131.024/94.0, AC. 1181/94, de 30 de setembro de 1994. Apesar da reunião com o ex-Presidente Itamar Franco, do encontro com o ex-Ministro Delcídio Gomez, e do Protocolo susbcrito pelo Superintendente Adjunto, todos inócuos juridicamente, é aquela Sentença que se acha em vigor, e a desistência daquele Processo, ou a modificação daquele julgado, depende de ajuste bilateral válido, no qual a petrobrás se faça representar em conformidade com, as disposições da Lei $2.004 / 53$ e dos seus Estatutos.

Acompanho o Voto do Sr. Ministro Relator que conclui pela abusividade do movimento grevista, entre outras coisas, pelo desrespeito à Ordem Judicial que determina, como manda a constituição e a Lei, a continuidade das atividades essenciais inadiáveis para a comunidade.

É o meu voto.

Ministro Almir Pazzianotto Pinto 
PODER JUDICIÁRIO

JUSTIÇA DO TRABALHO

TRIBUNAL SUPERIOR DO TRABALHO

TST-DC N $N^{2} \quad 177.734 / 95.1$

\section{VOTO CONVERGENTE DO EXM SR. MINISTRO ARMANDO DE BRITO}

Estamos vivendo de algum tempo a esta data momentos longos momentos até - de inquietação e desalento. Tomando ciência pela imprensa, pela ampla publicidade na televisão, ouvindo pronunciamentos do Congresso Nacional, sabemos que está deflagrado um movimento político-sindical para se opor às reformas constitucionais propostas pelo Governo. É clara a incitação aos eventos grevistas e às paralisações-relâmpago.

Eles querem exaurir a sociedade, vencendo-a pelo cansaço. Certos dirigentes sindicais fazem convocações iradas com discursos claudicantes na defesa dos monopólios, que, na realidade, se traduzem na defesa do lesivo sistema corporativista-imobilista enquistado nas estatais e trazendo danos graves à economia nacional. Num ensejo em que o Governo, tentando debelar a inflação, não permite há meses que subam os preços de tarifas públicas; a gasolina, em episódio inédito neste País, até baixou de preço. Com a greve dos marítimos, ontem julgada abusiva e com esta greve-surpresa na 2 a feira, engendrada na calada da noite de domingo pelos Rodoviários na Capital da República, temos o abuso do uso da liberdade. Estamos, pois, ante uma situação de rebeldia contra as instituições; onde já se não obedecem às ordens judiciais de manter em funcionamento $30 \%$ (trinta por cento) das atividades das categorias em greve.

Julgará este Tribunal, em seguida, a greve dos Eletricitários, a dos Portuários, a dos Metroviários em São Paulo, a dos Correios, a dos Ferroviários e, quiçá, de outras e outras categorias que exercem atividades essenciais, principalmente aquelas ligadas à CUT e relacionadas com o Estado por vínculo administrativo. Seria de se indagar se pretendem, pela forca, tais políticos-sindicalistas governar o País; mas, inviabilizando-o antes como Nação.

A questão da greve política, portanto, precisa ser olhada como matéria diretamente ligada à sobrevivência da ordem democrática, ou seja, como verdadeira questão de segurança nacional.

Não é possível os 150 milhões de brasileiros ficarem reféns de $500 \mathrm{mil}$ funcionários grevistas de estatais, liderados por uma central sindical que perdeu as eleições politicas majoritárias para a Presidência da República e que tenta, por este modo, punir os eleitores que a derrotaram e, por via reflexa, ao seu candidato.

Não há lei democrática no mundo que, com tanta liberalidade, tenha cuidado desse tema "greve" em sua Constituição, escrita ou costumeira, de modo a erigir agrupamentos sindicais em um poder de Estado, com potencial para, querendo, e com motivação qualquer, paralisar um País.

Isto só se vê no Brasil. Nem a Organização Internacional do Trabalho sanciona tal, pois, sendo ela um organismo da ONU, cuida de que os países respeitem equanimemente os direitos mínimos dos trabalhadores, sem colocar em perigo as liberdades democráticas fundamentais. Dentre elas a da livre e responsável atuação sindical, apartada, sim, da tutela de governos, mas jamais tornada em poder supraestatal, colocada acima da ordem jurídica.

Por essas razões da vivência desses dias, em que organismos sobrevivem de contribuiçöes confederativas e de partidos políticos, é que se devem ter ceifadas da constituição as normas dúbias em que, com audácia, a organização sindical lastreia suas posições e tumultua, impondo reacões no próprio meio obreiro, inconformado com tal ação política deletéria e, portanto, trazendo' a insegurança para a vida dos cidadãos e da coletividade.

As reiteradas manifestações legais e moderadoras da Justiça do Trabalho, quando chamada a apreciar dissídios de greve, $\mathrm{K}: 10 \mathrm{DC} 117773495$. SAM 
estão se tornando desgastantes para o próprio Judiciário, eis que as direções supra-sindicais politizadas não cumprem as decisões.

$$
\text { E o pior é que, ainda, por vezes após os julgamentos }
$$

definitivos, são chamadas aos conciliábulos nos mais altos escalões do Executivo, numa tentativa vã, a nosso ver, de manter uma pacífica convivência. É necessário, sim, e urgente expungir o texto quase irresponsável inserido no caput do art. $9^{\circ}$ da constituição, para torná-10 um referencial sério e assegurador de um direito a fim de tornar claro para o leigo em Direito que não é ele absoluto e irrestrito - o da greve por qualquer motivo, em qualquer oportunidade a critério das lideranças.

Esperar que se cometam abusos e mais abusos para reprimir os responsáveis segundo as penas da lei, conforme escrito no $\S 2^{\circ}$ do mesmo art. $9^{\circ}$, é postergar uma solução, é quase projetar uma impunidade, porque, em movimentos de massa, ficam diluidas as responsabilidades, justificando os sindicatos e seus dirigentes que o movimento, que escapou ao seu controle, tinha finalidade econômica quase sempre um pretexto -, dada a revolta dos trabalhadores com a política das reformas constitucionais, etc. etc. E, assim, na verdade, malgrado os prejuízos para o país e seu povo, sempre os abusos ficam impunes.

É por isso, vislumbrando na greve dos petroleiros mais uma tentativa de sublevar o Pais, e mais uma vez deplorando as leis brandas ou dúbias que temos, voto pela abusividade da greve dos petroleiros em defesa da sobrevivência da ordem jurídica e da sobrevivência das instituições democráticas que muitos dirigentes timbram por atos ou por omissões em levar à derrocada.

Brasilia, 09 de maio de 1995.

ARMANDO DE BRITO

Ministro do TST 
ANEXO 07

Dissidio Coletivo de 2012 - Greve na PUC/SP. TRT/SDC 005134-84.2012.5.02.0000.

Decisão do Tribunal Superior do Trabalho

(Os respectivos originais pertencem aos autos judiciais provenientes do Tribunal Regional do Trabalho da $2^{\text {a }}$ Região)

Processo TRT/SDC 005134-84.2012.5.02.0000.

Espécie: Dissídio Coletivo de Greve

SUSCITANTE: FUNDAÇÃO SÃO PAULO - MANTENEDORA DA PONTIFÍCIA UNIVERSIDADE CATÓLICA DE SÃO PAULO.

\section{SUSCITADOS: SINDICATO DOS PROFESSORES DE SÃO PAULO - SINPRO E SAAEP - SINDICATO DOS AUXILIARES DE ADMINISTRAÇÃO ESCOLAR DE SÃO PAULO.}

A suscitante ajuizou o presente dissídio coletivo de greve aduzindo que: (a) não houve notificação da suscitante; (b) necessidade de esgotamento das vias negociais; (c) no dia 19 de novembro de 2012 foi comunicado que os sindicatos teriam deliberado pela greve, sendo que a informação teria sido confirmada em 21 de novembro de 2012; não há reivindicação de cunho trabalhista; a greve seria para fins de protesto contra a nomeação da nova reitora da entidade suscitante; (d) abusividade do movimento ante a não presença dos requisitos legais - Lei 7.783/89; (e) invoca a urgência e o poder geral de cautela; (f) como pedido, solicita o retorno imediato ao trabalho, além da fixação de multa e a autorização para o desconto dos dias relativos à paralisação. Junta procuração e documentos.

A Desembargadora, Rilma Aparecida Hemetério, consoante a r. determinação de fls. 73, indeferiu a liminar requerida, aduzindo, em linhas objetivas, que a atividade desenvolvida pela suscitante não se enquadra nas hipóteses dos artigos 10 e 11, da Lei 7.783/89, bem como não havia risco de prejuízos as equipamentos ou máquinas da empresa.

Houve a designação de audiência de instrução e conciliação (fls. 74).

Pedido de reconsideração formulado às fls. 82/85, com a juntada de documentos. O pedido foi indeferido às fls. 86 .

Houve a realização da audiência de instrução e conciliação ás fls. 93/94. Pontos de destaque: (a) o primeiro suscitado reconheceu movimento de protesto com paralisação principal de alunos e adesão parcial de professores pela situação decorrente dos critérios de escolha do novo reitor da suscitante; (b) o segundo suscitado aduziu que os empregados deliberaram pela greve, contudo, esta não teria ocorrido; (c) o suscitante confirmou que de 15 a 20 funcionários fizeram greve e que a paralisação dos professores atingiu em torno de $50 \%$ dos trabalhadores; (d) o primeiro suscitado indicou que os professores comparecem às aulas, mas os alunos não adentram à sala de aula como protesto à indicação do reitor; (e) o suscitante propôs que os professores retornassem ao trabalho, sendo que esta assertiva não foi aceita pelo primeiro suscitado sob o fundamento de que ficou estabelecido com o Conselho das Faculdades que as aulas perdidas seriam 
ministradas oportunamente mediante o sistema de compensação; (f) foi dito também pelas entidades sindicais suscitada que os procedimentos do vestibular não seriam prejudicados.

Contestação formulada pelo segundo suscitado às fls. 98/106, em que articula: (a) assembleia realizada no dia 14/11/2012, em que se aprovou a greve ante a não concordância com os critérios de nomeação do reitor; (b) houve a comunicação da greve, contudo, os trabalhadores aguardaram alguns dias antes do início do movimento; (c) em outra assembleia houve a deliberação de suspensão da greve; (d) perda do objeto da presente ação, visto que a greve foi encerrada antes do ajuizamento da demanda; (e) os trabalhadores não fizeram greve; (f) impugna os demais itens da inicial, indicando a não abusividade da greve. Junta procuração e documentos.

Contestação formulada pelo primeiro suscitado às fls. 194/198 em que articula: (a) não há greve e sim um protesto de toda a comunidade universitária deflagrado pelos estudantes ante a não concordância da escolha de quem seria o novo reitor da instituição; (b) como forma de afronta ao costume e a tradição democrática, a instituição teria escolhido como reitora a candidata que ficou em último lugar nas eleições realizadas na comunidade universitária; (d) a paralisação das aulas não pode ser imputada à categoria dos professores, visto que toda a comunidade universitária está envolvida em tais protestos contra a atitude da suscitante; (e) a Constituição Federal assegura o direito de greve, sendo que o exercício deste direito não se limita a reivindicações de natureza econômica. Junta procuração e documentos.

Manifestação do suscitante às fls. 247/254. Junta documentos.

Manifestação do segundo suscitado às fls. 260/261. Junta documentos.

Manifestação do Ministério Público do Trabalho às fls. 281/283.

Razões finais pela suscitante às fls. 284/290.

É o relatório.

\section{DECIDE-SE:}

01. Perda do objeto. Encerramento da greve antes ao ajuizamento do presente dissídio.

A paralisação ou não do movimento grevista não retira do suscitante o direito à prestação jurisdicional quanto ao reconhecimento judicial da abusidade ou não do movimento paredista.

A suscitante tem o pleno direito constitucional quanto a esta prestação jurisdicional (art. $5^{\circ}, \mathrm{XXXV}, \mathrm{CF}$ ).

Rejeita-se a preliminar argüida pelo $2^{\circ}$ suscitado (fls. 101).

01.1. Análise da preliminar do Ministério Público do Trabalho.

O Ministério Público do Trabalho entende que o presente dissídio deva ser julgado extinto ante a incompetência desta Justiça.

Divirjo da preliminar posta. Qualquer adjetivação que se dê a greve, seja típica ou atípica, abusiva ou não, é questão de mérito. Qualquer valoração de tais aspectos é mérito, cabendo ao Judiciário trabalhista avaliar ou não o abuso de direito.

Nos termos do artigo 114 da Constituição Federal e considerando que o direito de greve é inerente as relações coletivas de trabalho, bem como a tese de que o regramento técnico jurídico é o regime celetista, rejeita-se a preliminar.

02. Análise da Greve. Abusividade ou não? Exame apenas dos aspectos formais da Lei 7.783/89. 
Por lei, as hipóteses para que se tenha à configuração da greve abusiva são:

02.1. A greve, como cessação coletiva de trabalho, só pode ser tida como não abusiva após as tentativas necessárias para a negociação coletiva ou na impossibilidade da arbitragem (art. $3^{\circ}$, Lei 7.783/89).

A instituição, como se deflui da análise de todo o processado, procedeu à escolha do candidato menos votado para a condição de reitor (fls. 124). Houve a escolha em 12 de novembro de 2012.

Vale dizer, como se trata de uma greve política, na qual não se tem nenhuma conotação econômica, não se poderia exigir o requisito da exaustão da negociação coletiva.

Pela peculiaridade do movimento paredista, não há como se declarar a abusividade por este aspecto.

02.2. Compete à entidade sindical, convocar, na forma de seu estatuto, a assembleia-geral, a qual irá definir as reivindicações da categoria, bem como deliberará sobre a paralisação coletiva da prestação de serviços (art. $4^{\circ}$, caput, Lei 7.783/89).

Não se pode negar, ante o conteúdo de fls. 93 (audiência de conciliação e instrução), que houve a eclosão de movimento grevista por parte das duas categorias profissionais.

Esta valoração já foi analisada e inferida dos autos, consoante o tópico 01 de fls. 268/270:

"Pelo exame das informações trazidas às fls. 93, verso, ou seja, narrativa da própria entidade suscitante, '(...) que no máximo a paralisação dos trabalhadores da administração envolveu de 15 a 20 trabalhadores', bem como pela pontuação fática da réplica da suscitante (fls. 247/254, não há a necessidade de qualquer análise de liminar quanto à categoria dos trabalhadores da administração.

Quanto à categoria dos professores devemos acentuar que:

a) não se pode negar que se tenha uma paralisação dos professores, em especial, ante o teor de fls. 94 (verso), em que foi dito pela entidade sindical (primeiro suscitado), que:

'Pelo Sindicato dos Professores SINPRO foi aduzido que os alunos não adentram às salas de aula e por deliberação do Conselho das Faculdades ficou ajustado que as aulas perdidas por eles serão ministradas oportunamente em sistema de compensação e desta forma, estando os alunos paralisados em protesto e diante do ajustamento ocorrido torna-se impossível o acatamento da proposta da Suscitante sem gerar confrontos'.

Esta audiência foi realizada em 29 de novembro de 2012.

Também foi dito pelo primeiro suscitado que: 'Ademais, informa ainda que o protesto tem por fito modificar a indicação do Reitor questionado e enquanto esta não se efetivas, persiste o ajuste nos moldes anunciados para efeito de compensação de aulas' (fls. 94, verso).

O documento de fls. 255, datado de 29 de novembro de 2012 e que foi extraído do site oficial da entidade sindical (primeiro suscitado), menciona que a greve dos professores continua.

O documento de fls. 256, datado de 30 de novembro de 2012, indica que '... Os professores estão em greve permanente'.

Podemos afirmar que a paralisação é inquestionável."

Pelas peculiaridades do movimento grevista, não se pode exigir tamanho formalismo, como o previsto no art. $4^{\circ}$, da Lei $7.783 / 89$. Vale dizer, a repulsa natural quanto à escolha não foi só dos trabalhadores da 
administração e dos professores e sim e, principalmente, dos alunos da instituição. Por tais aspectos, esta greve não se reputa um movimento grevista típico. Como não foram extraídas reivindicações de natureza trabalhista, entendo que a realização da assembleia não pode ser exigida dos trabalhadores.

Se não bastassem tais assertivas, o $2^{\circ}$ suscitado fez a assembleia, cuja ata foi juntada aos autos (fls. 127), inclusive, com a juntada da lista dos presentes. Consta da ata que os empregados presentes deliberaram pela greve.

E, por fim, assevere-se que o $2^{\circ}$ suscitado levou ao conhecimento da suscitante, com o prazo legal exigível (48 horas, art. $3^{\circ}$, parágrafo único, Lei 7.783/89), quanto à eclosão da greve. O comunicado foi expedido no dia 14 de novembro de 2012, sendo que a greve foi estabelecida para o dia 21 de novembro de 2012.

Quanto ao $1^{\circ}$ suscitado, apesar da não realização de uma assembleia pela própria entidade sindical, concluí-se que pela análise dos documentos de fls. 234 a 240 que professores de vários departamentos decidiram em assembleias informais quanto à paralisação.

Estas assembleias indicam o inconformismo dos professores quanto ao procedimento da escolha do novo reitor.

Assevere-se ainda, que o Conselho da Faculdade de Direito deliberou pela legitimidade dos movimentos dos alunos, funcionários e professores (fls. 241).

O exame de tais elementos de prova reforça a convicção de que a greve é um ato refletido e consensual, ou seja, uma ponderação coletiva e como forma de repulsa ao critério de escolha do reitor.

Por tais fundamentos, como os elementos dos autos evidenciam o preenchimento teleológico do requisito do art. $4^{\circ}$, caput, da Lei 7.783/89, declara-se a não abusividade do movimento.

02.3. Aviso prévio para fins de greve (art. $3^{\circ}$, parágrafo único, Lei 7.783/89).

Como a suscitante não tem um objetivo social relacionado com serviços ou atividades essenciais (art. 10, II, Lei 7.783/89), a rigor, o aviso prévio para fins de greve é de 48 horas (art. $3^{\circ}$, parágrafo único).

O $2^{\circ}$ suscitado observou o prazo legal, como já analisado no tópico 02.2 supra.

Quanto ao $1^{\circ}$ suscitado, pelo exame dos autos, não houve este aspecto formal, contudo, é inegável que a empresa tinha plena ciência da greve, em especial, pelo desenvolvimento natural e do motivo que levou à greve.

Portanto, entendo que este aspecto não pode ser invocado como motivo a justificar a caracterização da greve como abusiva.

02.4. Quando a greve não é pacífica.

Pelo exame dos autos, é inegável que a greve é pacífica e dentro dos limites da normalidade. Nada há para ser apreciado neste sentido.

02.5. Prestação dos serviços indispensáveis ao atendimento das necessidades inadiáveis da comunidade (art. 11, Lei 7.783/89).

Esta indicação não é necessária ao caso em apreço, visto que o objetivo social da empresa não se enquadra como atividade essencial. Prejudicada a tese da abusividade ou não da greve por este fundamento.

02.6. Abuso também é configurado após a manutenção do movimento paredista, havendo a celebração de acordo ou convenção ou decisão da Justiça do Trabalho (art. 14, Lei 5.584/70). 
Não é o caso dos autos. A essência da greve foi em decorrência do critério de escolha do reitor.

02.7. Diante do exame dos autos, pelos aspectos formais, concluímos que a greve não é abusiva.

03. Estabilidade e os dias parados.

Como visto, do ponto de vista formal, a greve não é abusiva.

A decretação da abusividade ou não da greve, diante da leitura do art. $8^{\circ}$, da Lei $7.783 / 89$, não implica, necessariamente, no direito de o empregador proceder ao desconto dos dias ou das horas de paralisação na sua totalidade.

Neste sentido, consoante o teor de fls. 93 , verso e fls. 94 , a suscitante e o $2^{\circ}$ suscitado chegaram a um consenso (fls. 260/261), ou seja: "compensação de 50\% dos dias e pagamento dos restantes, observando-se efetivamente as faltas para cada trabalhador no período".

Para os professores ( $1^{\circ}$ suscitado), para que sejamos coerentes, entendemos, diante do teor de fls. 94, verso, em que o suscitado aduz o sistema de compensação, que nada poderá ser compensado. Vale dizer, a suscitante nada descontará dos salários dos professores que aderiram à greve, contudo, quando da reposição das aulas, nada lhes será devido por esta prestação dos serviços.

Pela peculiaridade da greve, não há amparo para a imposição de eventual estabilidade nos termos do PN 36 da SDC deste Tribunal, contudo, não será tolerado nenhum ato de retaliação por parte da entidade suscitante, visto que a simples adesão à greve não caracteriza falta grave (Súmula 316, STF). Se a empresa proceder à dispensa de professor ou funcionário, pela simples participação junto à greve, esta dispensa será considerada como ato discriminatório, nos termos da inteligência da Lei 9.029/95.

04. Abusividade material do direito de greve.

Quanto ao exercício do direito de greve, Mauricio Godinho Delgado ensina que a greve é um instrumento de pressão pelo qual os trabalhadores tentam a obtenção de melhores condições de trabalho e de salário. É o que se denomina de natureza econômico-profissional ou contratual trabalhista. Prossegue:

"O padrão geral das greves é circunscreverem-se às fronteiras do contrato de trabalho, ao âmbito dos interesses econômicos e profissionais dos empregados, que possam ser, de um modo ou de outro, atendidos pelo empregador. Os interesses contemplados em movimentos dessa ordem são, assim, regra geral, meramente econômico profissionais (isto é, interesses típicos ao contrato de trabalho)" (Delgado, Mauricio Godinho. Direito Coletivo do Trabalho. $3^{a}$ edição. São Paulo: LTr, 2008, p. 174).

Maurício Godinho Delgado afirma que a Constituição de 1988, ao contrário das anteriores, ampliou o direito de greve $\left(\right.$ art. $9^{\circ}$ ), ao determinar que compete aos trabalhadores "a decisão sobre a oportunidade de exercer o direito, assim como decidir a respeito dos interesses que devam por meio dele defender" (Ob. cit., p. 175).

Quanto aos interesses contemplados, Mauricio Godinho Delgado ensina:

"(...) é claro que a grande maioria das greves dirige-se apenas a temas contratuais, reivindicações trabalhistas, sendo esse o conduto essencial de desenvolvimento do instituto ao longo da história do capitalismo."

"Entretanto, sob o ponto de vista constitucional, as greves não necessitam circunscreveer-se a interesses estritamente contratais trabalhistas (embora tal restrição seja recomendável, do ponto de vista político-prático, em vista do risco da banalização do instituto - aspecto a ser avaliado pelos trabalhadores.'

"Isso significa que, a teor do comando constitucional, não são, em princípio, inválidos movimentos paredistas que defendam interesses que não sejam rigorosamente 
contratuais - como as greves de solidariedade e as chamadas políticas. A validade desses movimentos será inquestionável, em especial se a solidariedade ou a motivação política vincularem-se a fatores de significativa repercussão na vida e trabalho dos grevistas" (ob. cit., p. 179).

É inegável que o direito de greve não se resume tão somente como fator de pressão objetivando a melhoria econômica. Portanto, é possível a eclosão das denominadas greves de solidariedade ou as greves políticas.

Nos presentes autos, o primeiro suscitado, como representante da categoria dos professores, acentua que a greve política tem amparo constitucional.

$\mathrm{O}$ fato aduzido pela entidade sindical dos professores seria um protesto da comunidade acadêmica quanto a não indicação do candidato mais votado para a posição de reitor, o que, segundo a defesa (fls. 200/201):

"Todavia, este ano, o Grão Chanceler da Fundação São Paulo, ora Suscitante, afrontando o costume e a tradição democrática, simplesmente resolveu nomear como Reitora a candidata que ficou em último lugar nas eleições realizadas na comunidade universitária".

"Tal situação acarretou intenso protesto, não só no âmbito da PUC, mas no conjunto da sociedade brasileira. Os protestos contra a atitude arbitrária do atual Grão Chanceler tornaram-se fato público e notório dispensando provas".

Como dito às fls. 272, não poderíamos afirmar, em sede de cognição sumária, se os motivos alegados pela entidade sindical dos professores eram procedentes ou improcedentes para justificar a caracterização da paralisação como greve abusiva.

Asseveramos às fls. 273 que, ante a importância da suscitante no mundo da educação, é que a sua atitude de escolha do novo reitor causou grande perplexidade para a sua comunidade acadêmica.

E, como repulsa natural a esta forma de escolha do reitor, em não acatar o candidato mais votado, os professores e os alunos deliberaram em não mais participar das aulas, estabelecendo um sistema de compensação de aulas.

Agora, em sede de cognição exauriente, face ao conjunto probatório, é posta a nossa visão a apreciação dos demais integrantes desta SDC, declinando que:

a) é natural a atitude dos professores e funcionários, bem como dos alunos, quanto à deliberação coletiva da greve, visto que foi quebrada uma regra tradicional da instituição quanto à escolha do novo reitor;

b) a suscitante não é uma empresa ou um empregador que tem por objetivo a simples atividade econômica, com fins lucrativos. A PUC é uma instituição democrática e que tem um status de excelência dentre as instituições da sociedade brasileira;

c) como instituição democrática, ao romper com uma regra costumeira, de legitimação do candidato escolhido pela comunidade (o mais votado), deveria ter a consciência de que haveria uma repulsa natural por parte desta própria comunidade;

d) esta repulsa, como dito, é natural e não se equipara a dizer que os professores e os funcionários tenham manifestado os limites impostos pelo seu fim econômico ou social, pela boa-fé ou pelos bons costumes. Não há como se afirmar, ao ver deste juiz, que professores e funcionários tenham extrapolado o exercício do direito de greve. A reação foi equivalente ao ato da instituição.

Por tais aspectos, em sede de cognição exauriente, entende-se que a greve é política, como reação natural à quebra da confiança coletiva nos procedimentos de escolha do reitor. 
Por outro lado, também não há como se justificar que este procedimento fique eternizado pelos professores, já que, diante do teor de fls. 94 e pelo que consta dos autos, os funcionários já terminaram a greve. Não há como se determinar o retorno ao trabalho para esta categoria profissional.

Determina-se o retorno dos professores ao trabalho e que esperem os desdobramentos administrativos quanto ao desdobramento da escolha do reitor, inclusive, se for o caso a discussão judicial na esfera competente, contudo, o prosseguimento da greve implicará na caracterização de excesso quanto ao exercício deste direito.

A partir deste julgamento, os professores deverão retornar ao trabalho, de forma imediata, sob pena de ofensa a esta determinação judicial, indicando-se uma multa por dia de descumprimento desta cláusula a base de R $\$$ $10.000,00$, a ser revertida em prol da suscitante. A multa será paga pela entidade sindical suscitada (01).

\title{
CONCLUSÃO
}

Diante do exposto, ACORDAM os Magistrados da Seção de Dissídios Coletivos do Tribunal Regional do Trabalho da Segunda Região em:

a. rejeitar a preliminar argüida pelo $2^{\circ}$ suscitado e a aduzida pelo Ministério Público do Trabalho;

b) decretar a greve como não sendo abusiva;

c) autorizar que a empresa suscitante: (1) categoria profissional do $2^{\circ}$ suscitado - proceda a compensação de $50 \%$ dos dias e pagamento dos restantes, observando-se efetivamente as faltas para cada trabalhador no período; (2) categoria profissional do $1^{\circ}$ suscitado: nada descontará dos salários dos professores que aderiram à greve, contudo, quando da reposição das aulas, nada lhes será devido por esta prestação dos serviços.

d) pela peculiaridade da greve, não há amparo para a imposição de eventual estabilidade nos termos do PN 36 da SDC deste Tribunal, contudo, não será tolerado nenhum ato de retaliação por parte da entidade suscitante, visto que a simples adesão à greve não caracteriza falta grave (Súmula 316, STF). Se a empresa proceder à dispensa de professor ou funcionário, pela simples participação junto à greve, esta dispensa será considerada como ato discriminatório, nos termos da inteligência da Lei 9.029/95;

e) a partir deste julgamento, os professores deverão retornar ao trabalho, de forma imediata, sob pena de ofensa a esta determinação judicial, indicando-se uma multa por dia de descumprimento desta cláusula a base de $\mathrm{R} \$ 10.000,00$, a ser revertida em prol da suscitante. A multa será paga pela entidade sindical suscitada (01).

$\mathrm{Na}$ forma do art. 789, $\S 4^{\circ}$, CLT e considerando o disposto no art. 59 da Consolidação dos Provimentos da Corregedoria Geral da Justiça do Trabalho, para fins de decisão, fica estabelecido o valor de R\$80.000,00, fixando-se, assim, custas processuais no importe de R\$1.600,00.

O valor será rateado pelas partes: (a) suscitante - R \$ 534,00; (b) suscitados, para cada um - R \$ 533,00.

\author{
FRANCISCO FERREIRA JORGE NETO
}

DESEMBARGADOR RELATOR 